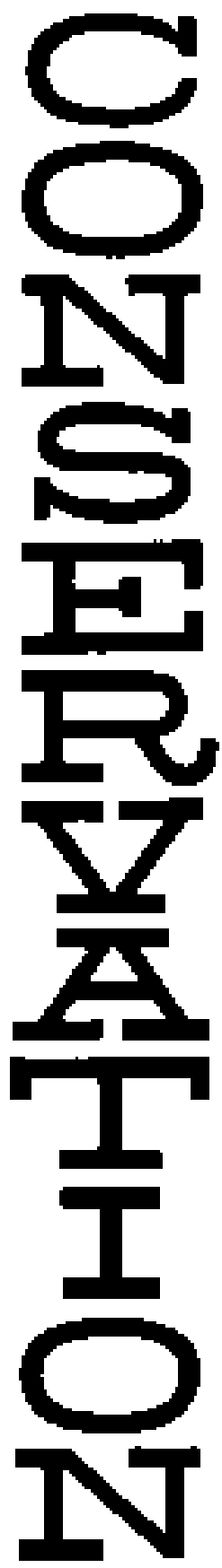

PROCEEDINGS OF THE 2002 NATIONAL OILHEAT RESEARCH ALLIANCE TECHNOLOGY SYMPOSIUM

Held at

Oilheat Visions Conference

Rhode Island Convention Center

Providence, Rhode Island

August 20-21, 2002

August 2002

Editor

Roger J. McDonald

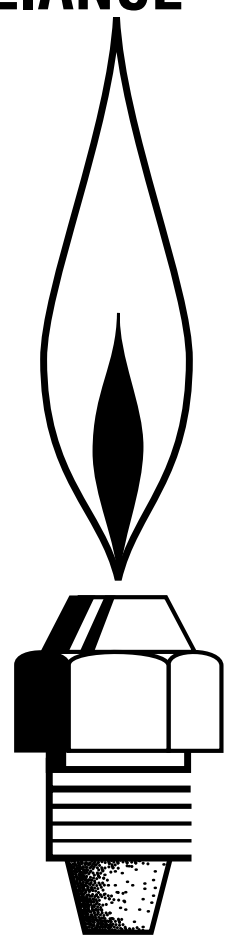

Sponsored by

Distributed Energy and Electricity Reliability Program Office of Energy Efficiency and Renewable Energy United States Department of Energy

National Oilheat Research Alliance

New England Fuel Institute

Petroleum Marketers Association of America

Energy Resources Division

Energy Sciences and Technology Department

Brookhaven National Laboratory

Brookhaven Science Associates

Upton, New York 11973-5000

Under Contract No. DE-AC02-98CH10886 with the UNITED STATES DEPARTMENT OF ENERGY 
BNL 52670

Formal Report

\title{
PROCEEDINGS OF THE 2002 NATIONAL OILHEAT RESEARCH ALLIANCE TECHNOLOGY SYMPOSIUM
}

\author{
Held at the \\ Oilheat Visions Conference (Track 4) \\ Rhode Island Convention Center \\ Providence, Rhode Island \\ August 20-21, 2002 \\ Editor \\ Roger J. McDonald
}

August 2002

Sponsored by

Distributed Energy and Electricity Reliability Program

Office of Energy Efficiency and Renewable Energy

United States Department of Energy

National Oilheat Research Alliance

New England Fuel Institute

Petroleum Marketers Association of America

Energy Resources Division

Energy Sciences and Technology Department

Brookhaven National Laboratory

Brookhaven Science Associates

Upton, New York 11973-5000

Under Contract No. DE-AC02-98CH10886 with the

UNITED STATES DEPARTMENT OF ENERGY 


\section{NOTE}

The timeliness of the material in this report requires prompt publication. Therefore, to expedite publication, these papers have been reproduced directly from the author's manuscripts. The conference sponsors, organizing committee, and staff disclaim any and all responsibilities for the contents of individual papers and abstracts.

\section{DISCLAIMER}

This report was prepared as an account of work sponsored by an agency of the United States Government. Neither the United States Government nor any agency thereof, nor any of their employees, nor any of their contractors, subcontractors, or their employees makes any warranty, express or implied, or assumes any legal liability or responsibility for the accuracy, completeness, or usefulness of any information, apparatus, product, or process disclosed, or represents that its use would not infringe privately owned rights. Reference herein to any specific commercial product, process, or service by trade name, trademark, manufacturer, or otherwise, does not necessarily constitute or imply its endorsement, recommendation, or favoring by the United States Government or any agency, contractor or subcontractor thereof. The views and opinions of authors expressed herein do not necessarily state or reflect those of the United States Government or any agency, contractor, or subcontractor thereof. 


\section{TABLE OF CONTENTS}

PAGE

ACKNOWLEDGMENTS.......................................................................... iv

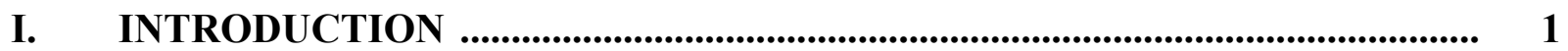

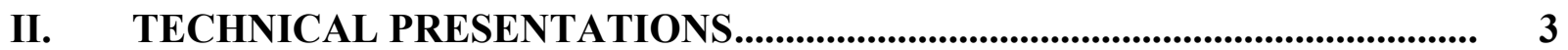

No. 02-01 Activities of the Institute for Economic Oilheating (IWO)

Dr. Christian Kuechen, IWO, Germany

No. 02-02 Oilheat Research at Brookhaven National Laboratory

T. Butcher, Ph.D., Yusuf Celebi, C. R. Krishna, Ph.D., Wai Lin Litzke,

Roger McDonald, Narinder Tutu, George Wei, BNL

No. 02-03 Maximizing Fuel Quality and Heating System Performance

Wai Lin Litzke, Yusuf Celebi, BNL \& David Daniels, Octel Starreon ..

No. 02-04 The Oilheat Industry Roadmap -

Towards a Sustainable Energy Future

Daniel Brewer, Energetics Inc.

No. 02-05

IES Heating Oil Fueled Microturbine Power Technology

Roger J. McDonald, BNL

No. 02-06 Update on Use of Bio Diesel Blends in Boilers

C. R. Krishna, Ph.D., T. Butcher, Ph.D., R. McDonald, Y. Celebi,

G. Wei, BNL, R Mills, Abbott \& Mills Inc.

No. 02-07

An Examination of Oil Burner Flue Gas Composition, Emissions

and Testing Technologies

Wesley Mellon, David D’Amico, Peter Cullen, Bacharach, Inc.

No. 02-08

Europe: Lowering $\mathrm{NO}_{\mathbf{x}}$ Emissions in Forced-Draft Burners

- Practical Considerations for North America

P. Bolognin, A. Cervato, F. De Boni, B. Marracino, Riello Burners, Italy

and edited by S. Williams, Riello Burners North America

No. 02-09 Low Cost/No Cost Techniques to reduce NOx in Residential Oil Burners

Charles Feldman, David Engley, Michael Shayda and Kenneth Stadtlander,

Carlin Combustion Technology, Inc.

No. 02-10 Factors Affecting Oil Burner NOx Emissions

Victor Turk, R.W. Beckett Corp.

No. 02-11 The Autothermal Evaporation of Liquid Fuels by Using Cool Flames

Klaus Lucka, Ph.D. and Heinrich Koehne, OWI Germany

No. 02-12 Results of the Flame Quality Monitor Field Test Program

Thomas Butcher, Ph.D., BNL, Henry Troost, P.E., Honeywell,

Andrew Rudin, Insight Technologies

No. 02-13 Assessing PM PM.5 $_{2}$ Emissions from Distillate Fuel Oil Heating

S. Win Lee, I. He, T. Herage, E. Kelly and B. Young

CANMET Energy Technology Center.

No. 02-14 Oil Fired Pulse Combustion Boiler

Garry O. Hanson HVAC Consultants, Inc. 
No. 02-15 Evaluation for Commercialization of Small Oil Fired Condensing Boilers in North America

Harvey Stenger, PE.

No. 02-16 Description of a New Nozzle for Variable Firing Rates

Juergen Kohlman, Ph.D. Berlin University ....................................................

\section{ACKNOWLEDGMENTS}

The 2002 National Oilheat Research Alliance Technology Symposium required the dedicated effort of many people to make it successful. The editor of this report would like first to thank the authors for their efforts and splendid cooperation in submitting papers promptly. The BNL staff also wishes to recognize the contributions to our work by our U.S. DOE program manager, Ronald Fiskum, and thank him for his leadership. The editor also greatly acknowledges the hard work and effort required by the entire BNL program staff to make this meeting a success. Most of all the staff at BNL wish to thank all of our 2002 National Oilheat Research Alliance Technology Symposium sponsors and participants for their active participation. 


\section{INTRODUCTION}

This meeting is the fifteenth oilheat industry technology meeting held since 1984 and the second since the National Oilheat Research Alliance (NORA) was formed. This year's symposium is a very important part of the effort in technology transfer, which is supported by the Oilheat Research Program under the United States Department of Energy, Distributed Energy and Electricity Reliability Program (DEER). The foremost reason for the conference is to provide a platform for the exchange of information and perspectives among international researchers, engineers, manufacturers, service technicians, and marketers of oil-fired space-conditioning equipment. The conference provides a conduit by which information and ideas can be exchanged to examine present technologies, as well as helping to develop the future course for oil heating advancement. These conferences also serve as a stage for unifying government representatives, researchers, fuel oil marketers, and other members of the oil-heat industry in addressing technology advancements in this important energy use sector. The specific objectives of the conference are to:

o Identify and evaluate the current state-of-the-art and recommend new initiatives for higher efficiency, a cleaner environment, and to satisfy consumer needs costeffectively, reliably, and safely;

o Foster cooperative interactions among federal and industrial representatives for the common goal of sustained economic growth and energy security via energy conservation.

The 2002 National Oilheat Research Alliance Technology Symposium is sponsored by the Distributed Energy and Electricity Reliability Program (DEER) within the Office of Energy Efficiency and Renewable Energy (EERE) at the United States Department of Energy (DOE), the National Oilheat Research Alliance (NORA), the New England Fuel Institute (NEFI), Brookhaven National Laboratory (BNL) and the Petroleum Marketers Association of America (PMAA). BNL is proud to acknowledge all of our sponsors, with their help and support this has correctly become an oilheat industry meeting. It is quite gratifying to see an industry come together to help support an activity like the technology symposium, for the benefit of the industry as a whole.

Introductory remarks will be provided by Doug Woosnam, Chairman of the NORA Research and Development Committee who will welcome the assembly on behalf of our sponsors. He will emphasize the continued commitment by NORA, DOE and BNL to advancing oil heat technology and effecting technology transfer to the private sector. As the Master of Ceremonies, Doug Woosnam will also introduce the symposium speakers stating with the Keynote Presentation, which will be given by Dr. Christian Kuechen, Institute for Economic Oilheating (Institut fuer wirtschaftliche Oelheizung, IWO, Hamburg, Germany).

Sixteen technical presentations will be made during the two-day program, all related to oilheat technology and equipment, these will cover a range of research, developmental, and demonstration activities being conducted within the United States and Europe, including:

- Activities of the Institute for Economic Oilheating (IWO, Germany)

- Oilheat Research at Brookhaven National Laboratory

- Maximizing Fuel Quality and Heating System Performance

- The Oilheat Industry Roadmap - Towards a Sustainable Energy Future 
- IES Heating Oil Fueled Microturbine Power Technology

- Update on Use of Bio Diesel Blends in Boilers

- An Examination of Oil Burner Flue Gas Composition, Emissions and Testing Technologies

- Europe: Lowering $\mathrm{NO}_{\mathrm{x}}$ Emissions in Forced-Draft Burners - Practical Considerations for North America

- Low Cost/No Cost Techniques to reduce NOx in Residential Oil Burners

- Factors Affecting Oil Burner NOx Emissions

- The Autothermal Evaporation of Liquid Fuels by Using Cool Flames

- Results of Flame Quality Monitor Field Tests

- Assessing $\mathrm{PM}_{2.5}$ Emissions from Distillate Fuel Oil Heating

- Oil Fired Pulse Combustion Boiler

- Evaluation for Commercialization of Small Oil Fired Condensing Boilers in North America

- Description of a New Nozzle for Variable Firing Rates

Adjournment

Following the final group of technical presentations the formal portion of the symposium will be concluded with brief closing remarks by Roger McDonald, editor, symposium organizer and coprincipal investigator the BNL Oilheat Research Program.

Oilheat Research Laboratory

During the scheduled open house on August 22, following the formal conference sessions, pre-registered visitors will tour the BNL Oilheat Research Laboratory. Due to BNL's security requirements, all visitors must be pre-registered with BNL in advance and present photo identification on the day of their visit. BNL is located on Long Island in Upton, NY. The Oilheat Research Laboratory is located in building 526. Equipment demonstrations of some of the advanced oil-fired heating systems under development at BNL will be available. BNL will also provide numerous visual displays based on prior and ongoing research related to Oilheat Research. 


\section{Technical Papers}

Keynote Presentation

Paper No. 02-01

Activities of the Institute for Economic Oilheating

Dr. Christian Kuechen

Institut fuer wirtschaftliche Oelheizung, IWO

Suederstraße 73a

20097 Hamburg, Germany

Phone: +49 - (0)40 - 235113 - 21

Fax: +49 - (0)40 - 235113 - 29

E-mail: kuechen@iwo.de

Internet: www.iwo.de 
Activities of the Institute for Economic Oilheating

(Institut fuer wirtschaftliche Oelheizung, IWO, Hamburg, Germany)

Dr. Christian Kuechen

\section{Market of domestic heating oil in Europe and Germany}

In the past few years, the market for heating oil has developed differently throughout Europe. On the whole, there is increasing competition between the various energy sources. This has resulted in a reduced market share for oil heating systems and consequently decreased heating oil consumption in general. In addition to that, increasing insulation features and energy saving devices have exacerbated this development.

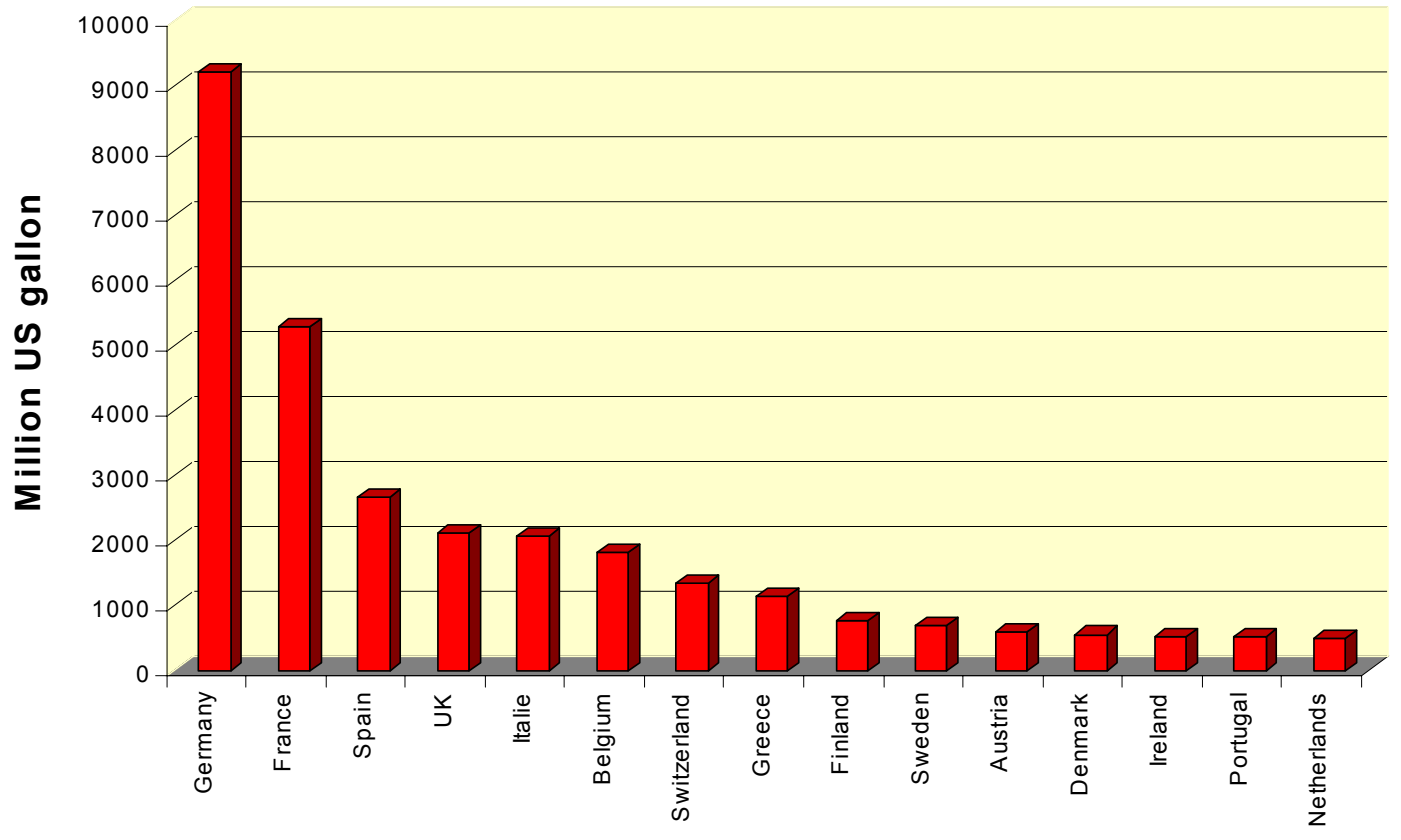

Fig. 1: Consumption of heating oil in Europe (2000)

In most European countries, the heating oil's main competitor is natural gas heating. In others, electric heating systems (like direct electric heating and electric heat pumps) have prevailed. On top of that, bio fuel has received a lot of attention - in the form of wooden pellets for example. Also, interest in combined systems with oil or gas heating and thermal solar energy has risen. In Germany, the market share of oil heating in new buildings has decreased in the recent past. Almost $75 \%$ of new flats and houses have natural gas heating. In approximately $80 \%$ of Germany, natural gas is available for heating purposes. 


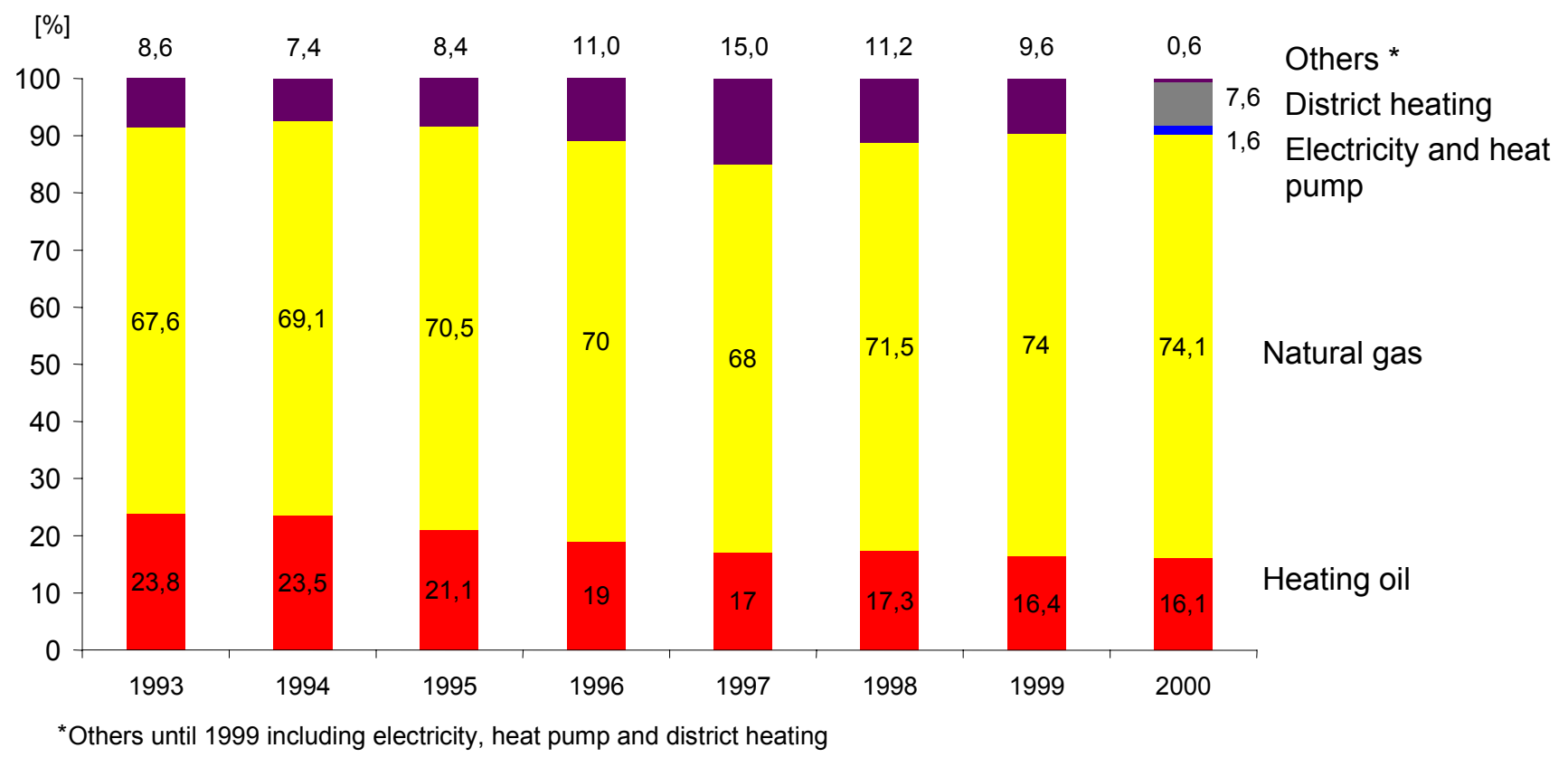

Fig. 2: Energy for heating in new buildings in Germany

All together there are 6.35 million oil heating installations in Germany. $30 \%$ are older than 20 years (figure 3 ).

There are approximately 4500 oil distributors, which supply the fuel to the customers. Many of them are independent but an increasing number is owned by the major oil companies. $60 \%$ of the fuel oil is refined in Germany. Almost $40 \%$ is imported as product.

The maintenance and the service is carried out by 15000 to 20000 technical service companies. Most of them are capable of installing gas heating as well. IWO has done market research every year since 1995 to find out what happens when an oil heater has to be renewed. Almost $50 \%$ are replaced by another energy, most of them by natural gas (figure 4). In recent years electric heat pumps and combustion of biomass became new competitors for heating oil, especially in those regions, where no gas is available.

The price of fuel oil in Germany has been on average $30 \%$ lower than the price for the equivalent amount of natural gas over the last 10 years. 


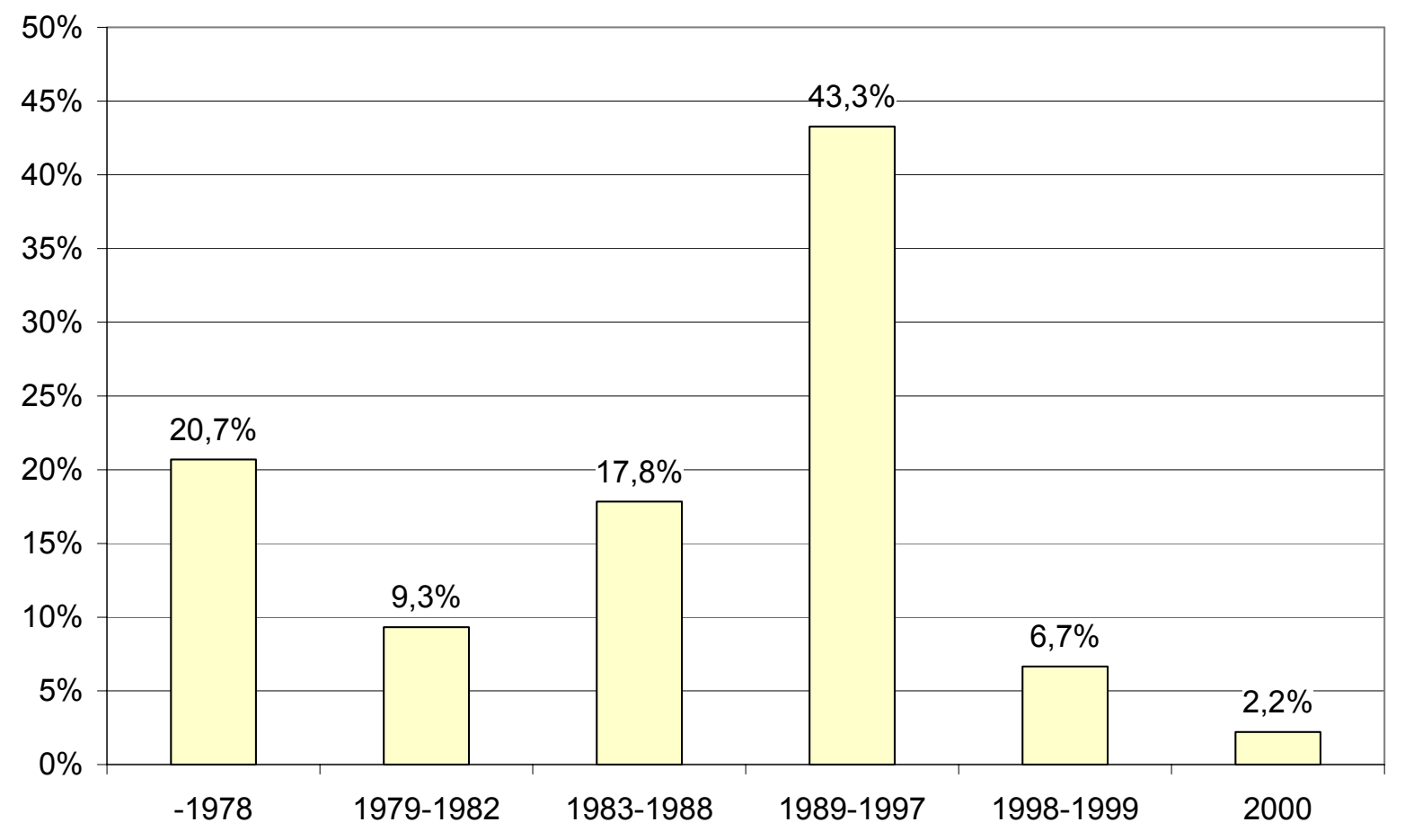

Fig. 3: Year of installation of oil heating appliances in Germany

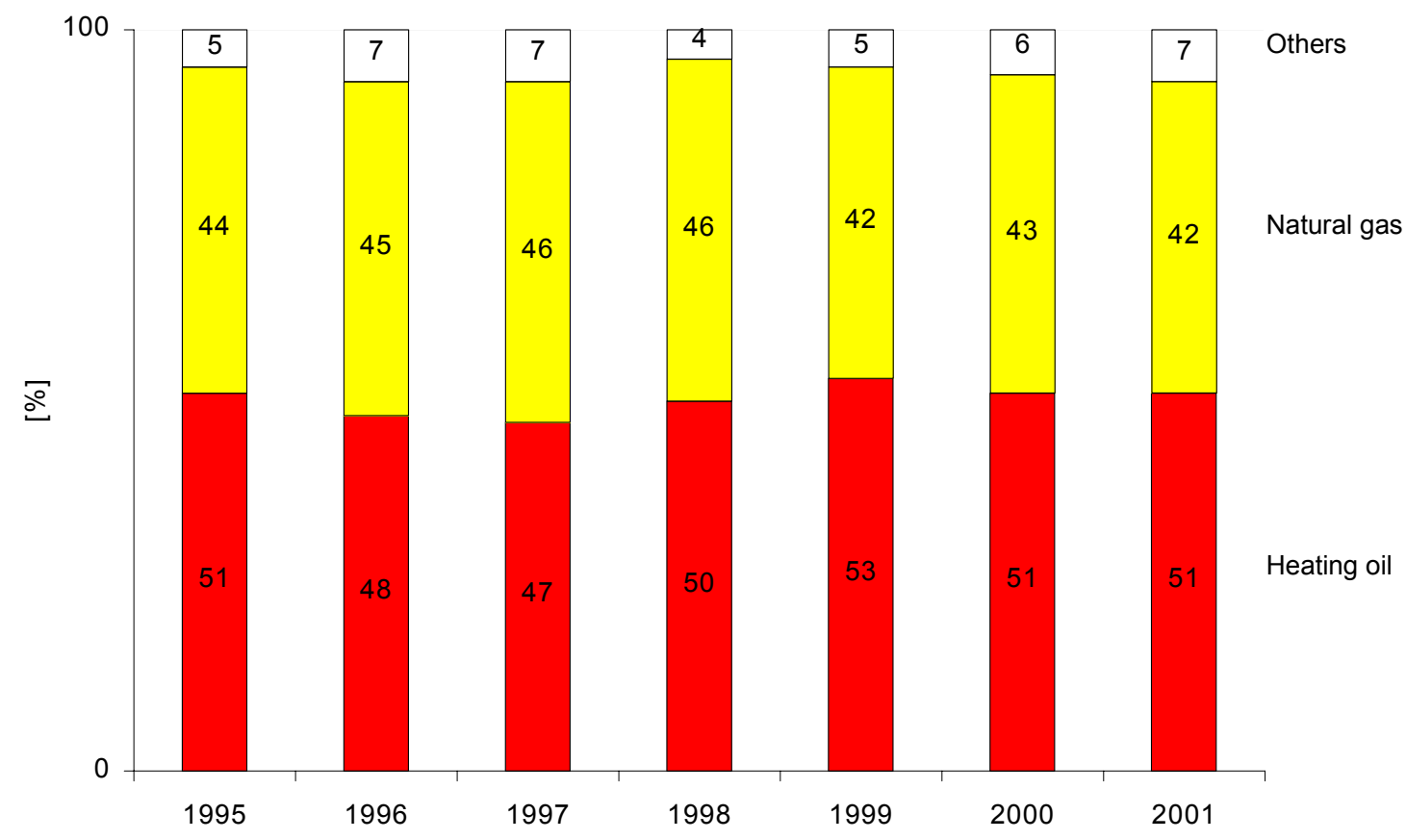

Fig. 4: Replacement of oil heating systems by oil, natural gas or other heating systems 


\section{European and national legislation and standardisation}

It has to be noted that national legislation and standards will be influenced by european directives and standards to an increasing extent. Examples are the efficiency directive for boilers, the directive for energy performance of buildings or the directive on energy efficieny requirements for end use equipments of buildings.

In Germany the „Energieeinsparverordnung“ (national directive for energy performance of buildings) came into force in february 2002. The main requirement for new buildings is the limitation of primary energy demand. As a result, not only the insulation of the building has to fulfill the requirements, but the heating technology as well. Furthermore the energy needed for conversion of primary energy like crude oil to domestic fuel oil has to be taken into account. Consequently money for insulation can be saved if an advanced heating technology such as condensing boilers is applied. In order to be competitive to other heating systems it is necessary to have high efficient oil heaters for a reasonable price.

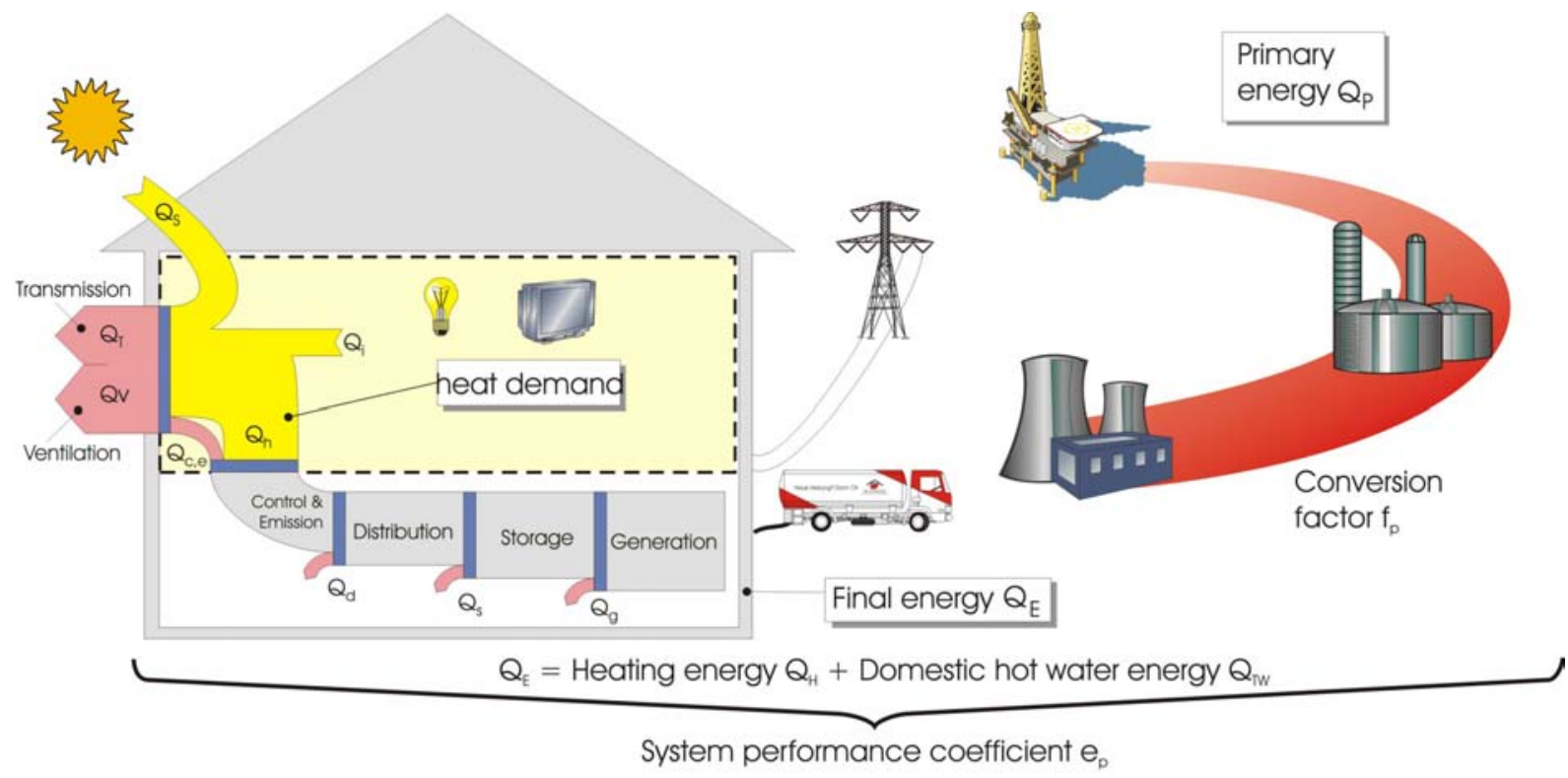

Fig. 5: Calculation of primary energy demand according to DINV 4701-10 (German national standard)

\section{IWO organization}

IWO, Institute for eonomic oil heating, was founded in 1984 by major oil companies in order to actively advance and support the development of oil-firing-technique and to strengthen fuel oil in the competition to other energie sources, namely natural gas. Today, numerous strong partners suport IWO to achieve the targets since IWO is an association of the German mineral oil industry and carried by the oil industry, the oil wholesale as well as the federations of the oil and fuel trade. The membership is 
voluntary. Well known manufactures of heaters and of components for the oil heating system support the work as associates.

Table 1:

\begin{tabular}{|l|l|}
\hline IWO-members & IWO-associates \\
\hline AGIP Deutschland AG & Bausparkasse Schwaebisch Hall AG \\
\hline ARAL Mineraloelvertrieb GmbH & BOMAT-Heiztechnik GmbH \\
\hline Beckmann Mineraloelhandel GmbH & Buderus Heiztechnik GmbH \\
\hline CONOCO Mineraloel GmbH & Bundesverband Lagerbehaelter e. V. \\
\hline Deutsche BP AG & Danfoss A/S \\
\hline DS-Mineraloel GmbH & De Dietrich Heiztechnik \\
\hline Eggert Mineraloel AG & Dehoust GmbH \\
\hline ESSO Deutschland GmbH & E-Technik AG \\
\hline F. J. Valentin Mineraloelgroßhandlung & ELCO Kloeckner Heiztechnik GmbH \\
\hline Gdbm & Electro-OIL GmbH \\
\hline HGM Roland Mineraloel Handel & ERC Emissions-Reduzierungs-Concepte GmbH \\
\hline HOLBORN European Marketing Co. & Froeling GmbH \& Co \\
\hline Louis Dreyfus \& Cie. Mineraloel GmbH & Giersch GmbH \\
\hline Mabanaft Deutschland GmbH & Guetegemeinschaft Standortgefertigte Tanks \\
\hline North Sea Mineraloelhandels GmbH & Initiative Pro Schornstein e. V. \\
\hline OMV Deutschland GmbH & Laudon GmbH \& Co. KG \\
\hline Petroplus Mineraloelprodukte Deutschland & Octel Deutschland GmbH \\
\hline RAG Vertrieb u. Handel AG & OERTLI-Rohleder Waermetechnik GmbH \\
\hline Shell \& DEA Oil GmbH & Oiltanking Deutschland GmbH \\
\hline Total Saarberg GmbH & Oventrop GmbH Co. KG \\
\hline TotalFinaElf Deutschland GmbH & ROTEX GmbH \\
\hline Van der Sluijs Haandelmaatschappij b.v. & Scheer Heiztechnik GmbH \\
\hline . & SOLVIS GmbH \& Co. KG \\
\hline & Vaillant GmbH \\
\hline & Viessmann Werke GmbH \& Co. \\
\hline & WESER-Petrol Seehafentanklager GmbH \\
\hline & Windhager Zentralheizung GmbH \\
\hline & \\
\hline
\end{tabular}

Every member contributes to the IWO-budget by a fee depending on the amount of heating oil sold (50 cents per $\mathrm{m}^{3}$ of heating oil since 2002). The associate members pay a fixed fee of 5200 Euro per year. The budget in 2002 is about 16 million Euro. More than $50 \%$ of the budget is spent directly for marketing activities. About $10 \%$ is needed for technical projects and technical information work.

IWO has 55 employees. Most of them (33), the regional representatives, are working from home based offices. 9 engineers are communicating with architects, heating engineers, chimney sweeps and maintenance people. 24 are consulting the local heating oil distributors and the heating engineers in order to improve their communication towards the customers. The main target is to initiate cooperation beween the local or regional oil-distributors and the heating engineers.

IWO generates and accumulates basic knowledge in research and development projekts, which are accompanied by equipment manufacturers. IWO cooperates with the appliance industry, technical committees as well as standard-committees. 


\section{$4 \quad$ Marketing activities}

In the past few years, the focus of marketing has changed considerably. In the mid-90s, IWO concentrated on national image campaigns for oil heating. Since the end of the 1990s, IWO has increased the regional and local marketing. More money has been spent on subsidising e.g. the advertising and promotion done by the oil suppliers and heating engineers. In order to promote this kind of marketing, IWO employs 33 regional representatives.

From experience we learnt that even this kind of focussed local marketing does not suffice. We realised we had to address the private customers directly, too. And this is why we have started our modernisation initiative. In this initiative, oil suppliers offer consultation vouchers to their customers with old oil heating systems. These vouchers can be redeemed with heating engineers. If the consultation results in the customer having his oil heating system modernised, IWO pays 50 to 100 Euros to the heating engineer for the consultancy.

In order to increase the number of consultations by heating engineers, we have set up the IWO Call Center. The oil supplier needs the technical specifications of his customers' oil heating systems. If the system proves to be older than 15 years, he sends the data on to the IWO Call Center. In addition to that, the oil supplier needs to be linked up with one or more partners from the technical side (heating engineers) who will be able to give his customers qualified consultation.

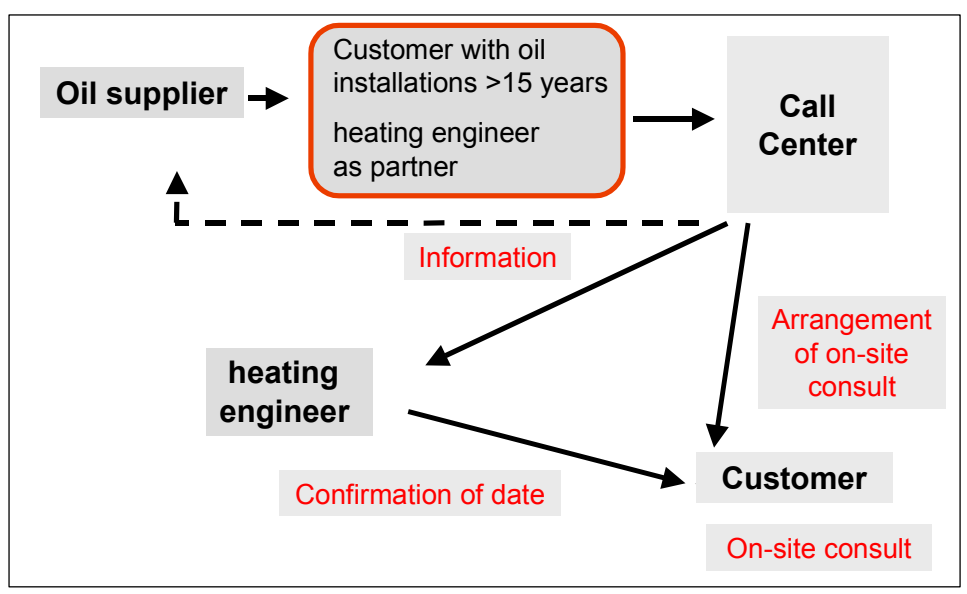

Fig. 6: IWO Call Center Service

Staff from the IWO Call Center contacts the customers on behalf of the oil supplier. Via the telephone, they advocate the advantages of oil heating and the benefits of modernising the oil heating system. They assess which customer is willing to modernise his oil heating in the near future. If the customer is interested, the IWO Call Center suggests a time frame during which an on-site consultation with a heating engineer can 
be arranged. The supplier and the engineers are informed of the current stage of the process. The customer receives a detailed information package, which also contains a voucher for the on-site consultation visit. The heating engineer arranges the exact date with the customer and discusses all the specific details with him. Of course, IWO is offering free training for participating heating engineers.

This year, we are planning to contact 250000 customers with dated oil heating systems through our Call Center. So far, we have managed 120000 individual calls, and experience shows that $99 \%$ of the customers are satisfied with the initiative itself. $6 \%$ want an on-site consultation. In many cases, the prerequisite for participation - namely the existence of customer data - is non existent. This is why the IWO Call Center also offers customer address management to the oil suppliers - this, of course, is not free of charge.

In order to support regional co-operation even better, IWO representatives supervise more than 230 marketing communities. On the average, each community consists of 5 oil suppliers and 8 heating engineer companies. These regional structures are used to communicate with opinion makers like architects, chimney sweeps and heating engineers. IWO provides periocically technical and marketing information for more than 50000 opinion makers.

\section{$5 \quad$ Technical projects}

Basically, the technical activities can be split into 4 sectors:

Development projects

Projects of relevance to the present situation

$>$ Technical lobbyism

$>$ Providing technical information

\subsection{Development projects}

Together with heater and component manufactures, IWO carries out research projects in order to develop basic knowledge for todays and future applications. The results are presented in technical periodicals and conferences as well as trade fares. At present research work is being carried out on the following subjects:

$>$ New burner concepts (Surface burner, low throughput burner)

$>$ Fuel cell technology

High temperature corrosion in oil burners

In recent years the development of oil burners concentrated on reduction of NOxemissions. A modern blue flame burner has NOx-emissions of approximately 100 
$\mathrm{mg} / \mathrm{kWh}$. At the same time, soot emission is reduced to a minimum. Today, the reduction of combustion noise becomes more important as well as the development of low-throughput-systems in the range from 5 to $15 \mathrm{~kW}$ and the amount of electric energy needed to run the burner.

All modern combustion systems have one design feature in common. A technology is used which generates an ignitable mixture from the liquid fuel and air. The generation of the mixture is a key factor in terms of the quality of combustion. If the mixture of the components is not homogeneous, an increased amount of harmful substances are likely to form. For example, a lack of oxygen leads a higher amount of unburnt hydrocarbons and soot in the exhaust gas.

In recent years, there has been a lot of research work carried out on the evaporation technology of domestic heating oil. As a result new concepts for oil burners may come to the market in near future. It is possible to premix completely oil and combustion air without igniting the mixture. That gaseous mixture can be burnt in pores or on a surface. A good example is the prototype of a radiant burner, which has been developed by the Oil heating institute (OWI) in Aachen, Germany. This new type of burner allows the construction of very small combustion chambers as the heat transfer is improved by radiation. On the other hand the combustion noise of that system is very low, which gives advantages in installation.

This new evaporation technology can be used in the reforming of fuel oil to hydrogen and carbon monoxide. Both gases are used as fuel in high temperature fuel cells. In the IWO-project different prototypes of fuel processors have been developed and tested. It could be demonstrated that fuel oil can be used as feedstock for fuel cells. In 2001 ARAL (german oil company) and SulzerHexis from Switzerland presented a cooperation project for development and fieldtests of fuel cells for domestic applications with fuel oil.

In all the new applications high temperature resistant materials are needed. Therefore IWO started a project to investigate different materials in typical applications in the temperature range from 600 to $1050{ }^{\circ} \mathrm{C}\left(1110\right.$ to $\left.1920^{\circ} \mathrm{F}\right)$. In this project the influence of sulfur content of the fuel is an important parameter.

\subsection{Projects of relevance to the present situation}

Field studies, which have been carried out by IWO over more than 6 years have shown, that savings from 6 to $10 \%$ can be realized by condensing boiler technology in comparison to modern boilers.

In spite of these developments, the market share of oil condensing boilers is still very low. This is because of the higher sulfur content of heating oil compared to natural gas, which requires more expensive heat exchanger materials (resistant to corrosion) and gives a more acidic condensate. In most cases condensate treatment is necessary before discharging it to the drain. Both lead to higher system costs which cannot usually be justified by the energy savings in a residential system. 
In 2001, German oil industry decided to develop and define the standards for a low sulfur fuel oil in order to meet three requirements:

The condensate from condensing boilers should be allowed to be discharged to the drain without treatment.

$>$ Materials for boilers and venting systems should be the same as with gas condensing boilers.

$>$ Fouling of heat-transfer surfaces due to formation of low-temperature corrosion products should be reduced.

In 2001 and in 2002 bench and field tests have been carried out together with the equipment manufacturers. Finally it was decided to set the Sulfur-limit for low-sulfur heating oil to $50 \mathrm{mg} / \mathrm{kg}$, which is in fact comparable to natural gas.

It is expected, that OEMs will develop special condensing boilers for the new fuel oil quality. Viessmann already offers a wall hung oil condensing boiler, which is specially designed for the $50 \mathrm{mg} / \mathrm{kg}$ fuel oil. Finally the regulation for condensate treatment will be changed if low sulfer fuel is used.

At present there are ongoing investigations in respect to long term behaviour of the low sulfur fuel in existing and new equipment. 2 aspects are looked at more thoroughly, which are the behaviour of low sulfur fuel in oil pumps and high temperature corrosion of burner components like flame tubes.

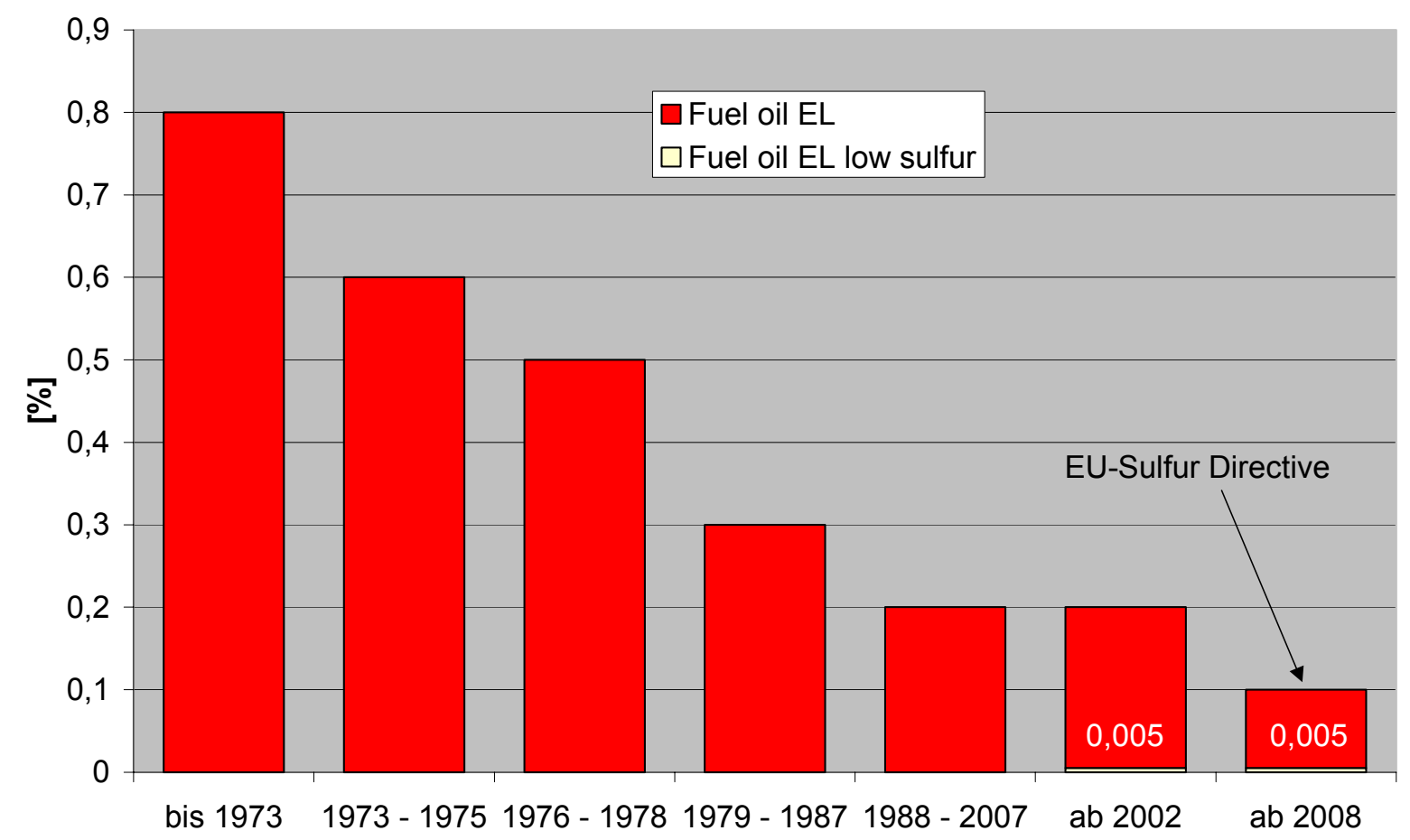

Fig. 5: Development of sulfur-limit in domestic fuel oil 


\subsection{Technical lobbyism}

In recent years it became evident, that there will be an increasing number of restrictions for the installation of oil heating systems. This is mainly because of stricter legislation concerning the prevention of water pollution and because of new standards for energy efficiency. In order to improve the basic conditions IWO decided to be present in all the relevant committees. Furthermore IWO took the lead in the Eurofuel association, which brings together similar national organisations from Austria, Belgium, Denmark, Finland, France, Germany, Ireland, Luxemburg, Norway, Switzerland and UK. Eurofuel is based in Brussels and is keeping contact to EU-organisations and other european associations.

\subsection{Information brochures}

In order to improve the knowledge of architects, heating engineers, chimney sweeps etc, IWO develops and distributes technical brochures for free. The main topics are:

$>$ Basic knowledge on fuel oil and additives

$>$ Storage of fuel oil

$>$ How to handle technical problems

IWO is just preparing a handbook, in which all the standards, directives or the legislation are summarized, that are relevant for the installation of oil heating systems. Most of these brochures are developed in close cooperation with the IWO-members, the associations of the manufactures and the installers. 
Paper No. 02-02

Oilheat Research at Brookhaven National Laboratory

Dr. Thomas A. Butcher, Yusuf Celebi, Dr. C. R. Krishna, Wai Lin Litzke, Roger McDonald, Narinder Tutu, and George Wei

Brookhaven National Laboratory

Building 526

12 North Sixth St.

Upton, NY 11973-5000

Phone: 631-344-7916

Fax: 631-341-2359

E-mail: butcher@bnl.gov

Internet: www.bnl.gov 
Dr. Thomas A. Butcher, Yusuf Celebi, Dr. C. R. Krishna, Wai Lin Litzke, Roger McDonald, Narinder Tutu, and George Wei

The programs and capabilities in the Brookhaven National Laboratory (BNL) Oilheat Research Laboratory have evolved a great deal over the past 18 months and this process is continuing. Several factors are contributing to this but the most significant is the change in the responsibility for this facility to the Department of Energy's (DOE) Distributed Energy and Electric Reliability (DEER) Program. With this change DOE has organized, in cooperation with industry and other groups, a major examination of the current status of this industry, a vision for the future, and what is necessary to achieve this vision. The industry "Roadmap", which has been recently published documents the results of a great deal of work by many people. The next step is the completion of a 5year plan based on this roadmap and this is now being prepared. Among other things the roadmap calls for strong acceleration of technical progress in oilheat with dramatic NOx reductions, improved fuels and systems, improved equipment technologies, and the achievement of much greater energy utilization efficiency through integrated technologies such as microturbines with heat recovery, engine driven total energy packages, and thermally driven cooling. The capabilities and programs in the BNL lab have been evolving in-step with these exciting new directions. The purpose of this paper is to provide an overview of current BNL projects and developing lab capabilities.

The main part of the BNL lab, Figure 1, was totally renovated in 2001 under a special DOE project. This included removal of all equipment, repainting of the lab, installation of new measurement equipment and a new data acquisition and control system. The lab presently has three fixed test stands and the capability to add additional residential size boilers or furnaces for special tests as needed. Fuel consumption and energy output instrumentation allows studies of direct input-output efficiency under steady state or cyclic conditions. At present a programming effort is underway to allow computer operation of the fixed test stands to simulate a variety of winter or summer load conditions. This will allow testing of advanced burners, for example, under defined winter load profiles even in the summer. Typical seasonal load profiles are being defined based on prior BNL field test data. In addition to efficiency, the BNL lab includes capability to measure $\mathrm{CO}, \mathrm{NOx}$, and hydrocarbon emissions routinely both in steady state and during transients.

Another area which is seen as having increasing importance is particulate emissions. For some special tests we have replaced the hand-pumped smoke tester with a system which has a mechanical pump and positive displacement flow meter. This allows a precise amount of flue gas to be drawn through the filter paper over a controlled time period. For startup and shutdown transients this assures even sampling over time periods where conditions may be changing rapidly. For direct measure of the particulate emissions, we have, in the past made considerable use of hot filtering of the flue gas, under controlled conditions, with a pre-weighed filter. The procedure for this is well defined by the U.S. EPA and using this method allows direct comparison with other emission sources such as 


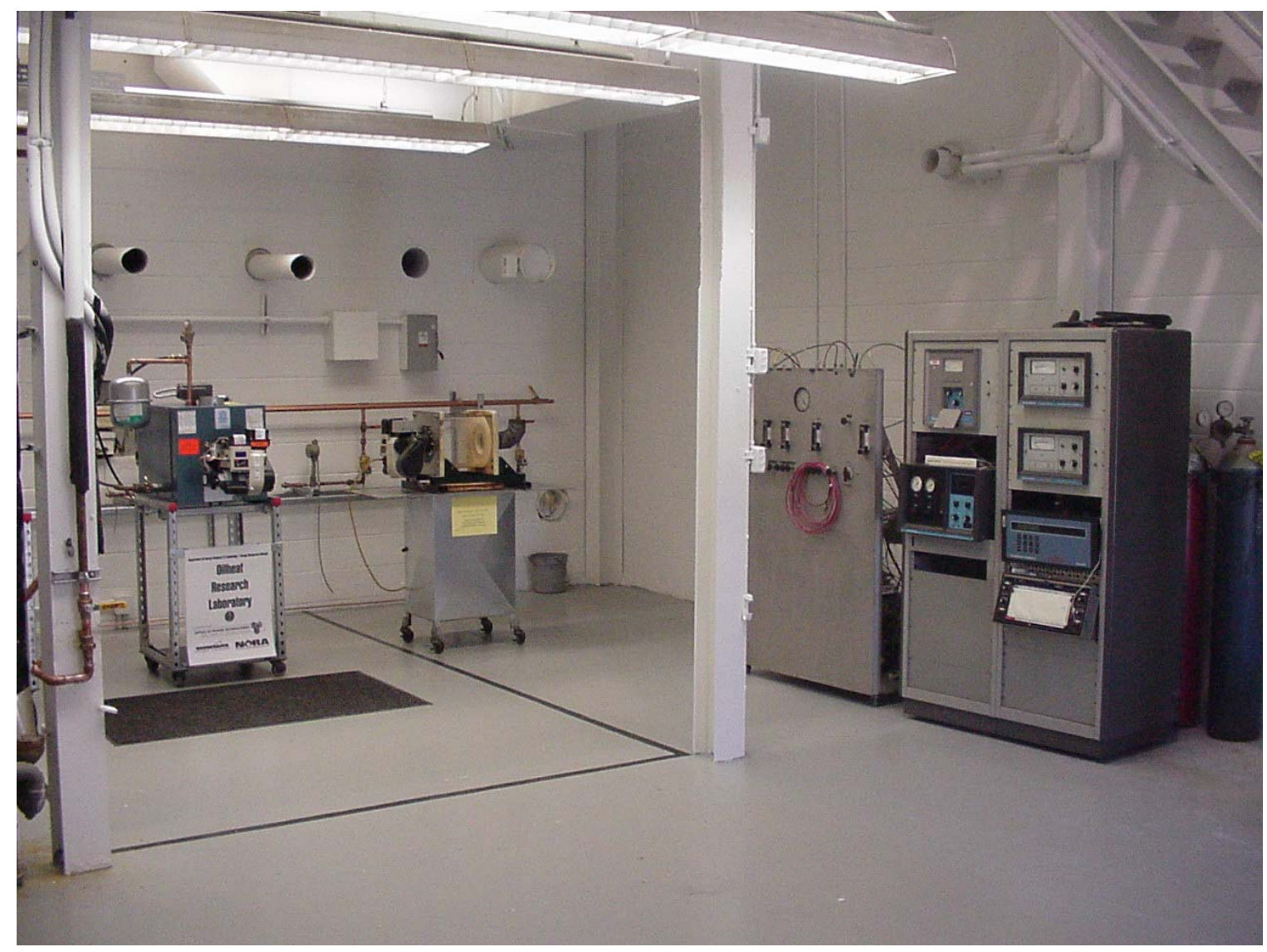

Figure 1. Renovated combustion lab at BNL

large industrial boilers. Prior BNL reports in this area [1] have been used to change (lower) the standard emission factors assigned by the EPA to oil burners. BNL capabilities in this area also include a cascade impactor system with which particulate size distribution can also be measured. At present there is a great deal of interest in the emission of fine particulates by a wide variety of sources. This includes not only particulates measured by hot filtration of the flue gas but also particulates produced when the flue gas mixes with air after leaving the chimney. These particulates can be formed by condensation of hydrocarbons, which are gaseous under flue conditions, and by the formation of sulfuric acid aerosols. Measurement of these fine particulates involves a dilution system in which part of the flue gas is mixed with ambient air under controlled conditions. Particulate total mass, size distribution, and composition may be measured after the dilution process. There is great interest in fine particulates measured after this dilution process because these present the greatest health impacts. A wide variety of emissions sources are being looked at in national programs with a multitude of sponsors. We are considering adding some capabilities in this area.

In prior work at BNL and also at the CANMET lab in Ottawa [2] , the benefits of low sulfur fuel in keeping heat exchangers clean have been documented. In a current project BNL is studying the use of very low sulfur oil to enable the commercialization of very high efficiency, condensing boilers. Over the past several years there has been great 
progress in this area in Europe. The objective of the BNL work is to study fouling of boilers, under condensing conditions, with varied sulfur content fuels. At present the U.S. average sulfur content is on the order of $2000 \mathrm{ppm}(.02 \mathrm{wt} \%)$. Low sulfur diesel fuel is $500 \mathrm{ppm}$. In Europe, a new premium fuel specification has recently been established with condensing boilers in mind at $50 \mathrm{ppm}(.005 \mathrm{wt} \%)$. In the BNL lab we have a premium fuel for testing with a sulfur level of $20 \mathrm{ppm}(.002 \mathrm{wt} \%)$. Two European, condensing, oil-fired boilers have been installed in the BNL lab for this project. One has a fixed firing rate, conventional yellow flame burner operating at 0.55 gph. The other has a two stage, blue flame burner with a low-end firing rate of about $0.33 \mathrm{gph}$. It achieves this firing rate using a conventional, pressure atomizer. A U.S. condensing gas boiler, converted to oil firing is also being added to this set. To enable the European boilers to run properly an electronic $110 \mathrm{~V} 60 \mathrm{hz}$ to $220 \mathrm{~V} 50 \mathrm{hz}$ power converter has been added to our laboratory.

In any condensing boiler the actual condensation rate, and efficiency, will be a strong function of the return water temperature which, in turn, is controlled by the distribution system. Figure 2 shows the measured condensation rate and efficiency for the first of the two boilers listed above, as measured at BNL. In most practical applications the condensation rate is likely to be very low for most of the operating time. In ongoing studies at BNL, these boilers will be operated for extended time periods with fuels with varied sulfur levels. Efficiency degradation over this time and condensing section fouling will be evaluated. Additionally condensation rate and condensate chemical analysis are being studied.

BNL has a long standing interest in advanced burner concept development and throughout the long history of this program this has included both internal concept development and support for concepts developing elsewhere. The industry roadmap discussed above defines a specific technical target of $20 \mathrm{ppm}$ NOx with a nitrogen-free fuel. This represents a dramatic reduction from levels typically found with current appliances which are well over 100 ppm (@3\% $\mathrm{O}_{2}$. While many approaches toward achieving NOx levels under $20 \mathrm{ppm}$ can be considered, the use of atomizing nozzles and burner heads with flame tubes and high internal recirculation rates would seem to be the most practical short term approach. Here the head is designed to have rapid mixing of fuel, air, and recirculated combustion products to minimize the peak flame temperatures which occur. Increasing the recirculation rate decreases the peak flame temperature and NOx emissions but also creates challenges in flame stability particularly during startup transients. Another approach which is employed, particularly for larger burners is the use of circumferential air staging - where some of the combustion air is introduced into the flame zone through a series of "fingers" arranged in a circle around the main nozzle. This creates alternating rich and lean zones in the combustion zone.

BNL has several tools which can be used to understand and optimize the complex flow patterns and spray/air flow interactions in highly recirculating burners. One tool is the laser spray analysis system which provides detailed information on size distribution. A second tool added more recently is a Laser Doppler Velocimeter (LDV) system which is used to precisely map the air flow velocity field produced by different head geometries. 

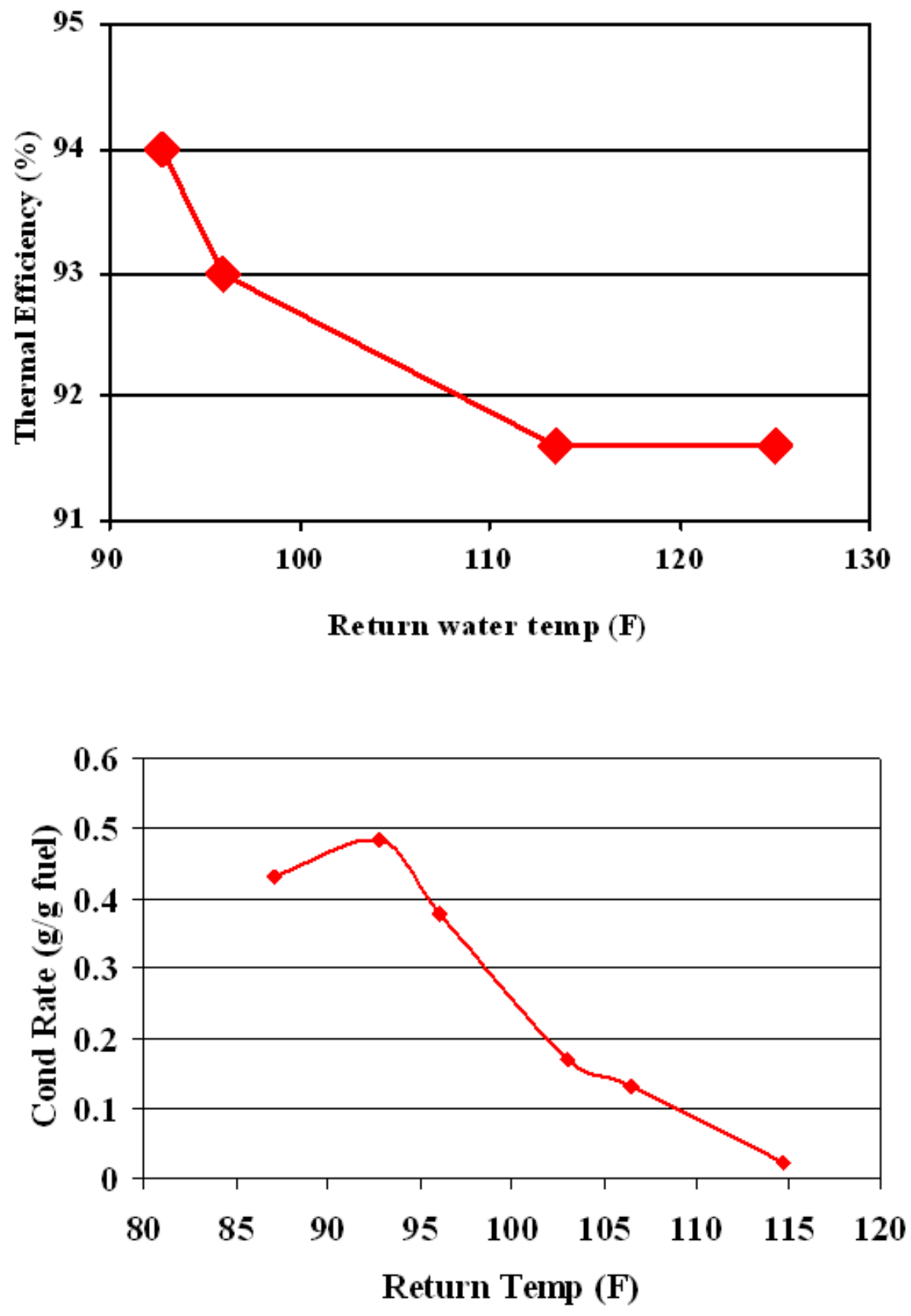

Figure 2 Oil-fired condensing boiler. Impact of return water temperature on measured efficiency and water condensation rate 
With this system the combustion air is "seeded" by adding submicron size solid particles which follow the air flow streams. A pair of laser beams is directed to a small measurement volume. The scatter pattern produced by the interaction of the laser beams and the solid particles is measured and analyzed by a computer to determine the air velocity patterns. Figure 3 shows, for example, the air flow patterns produced by a typical European low NOx burner.

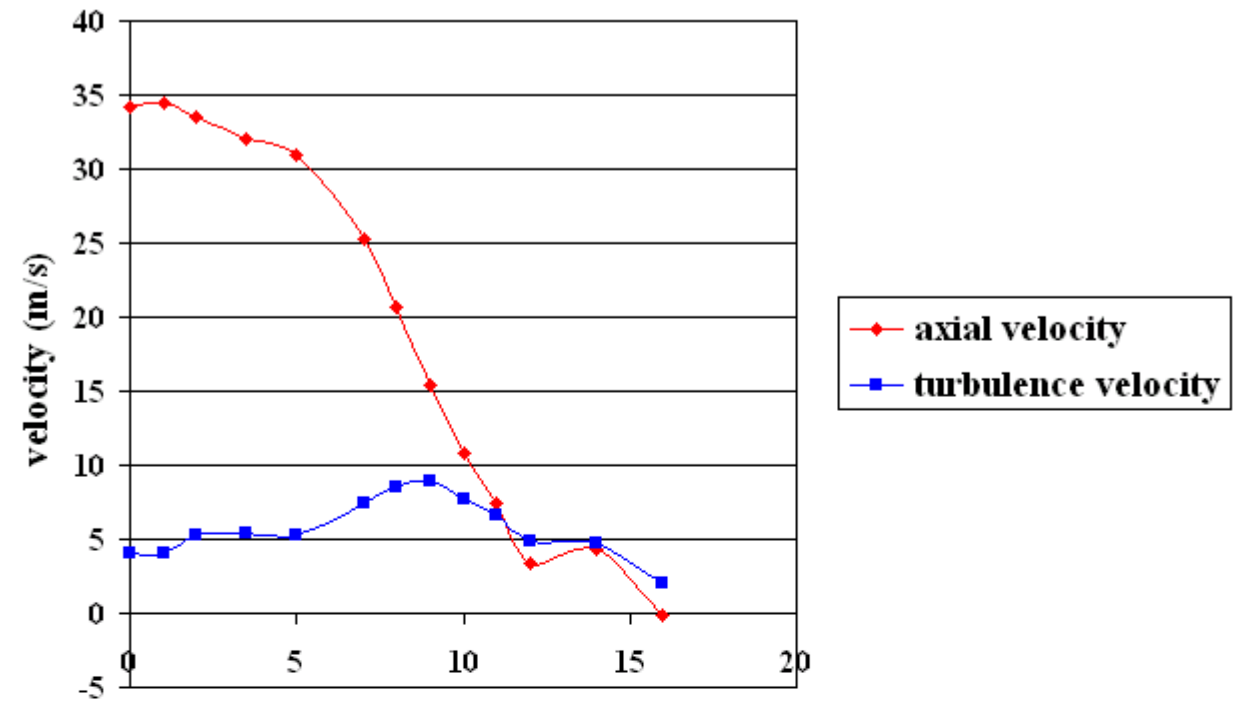

distance from centerline ( $(\mathrm{mm})$

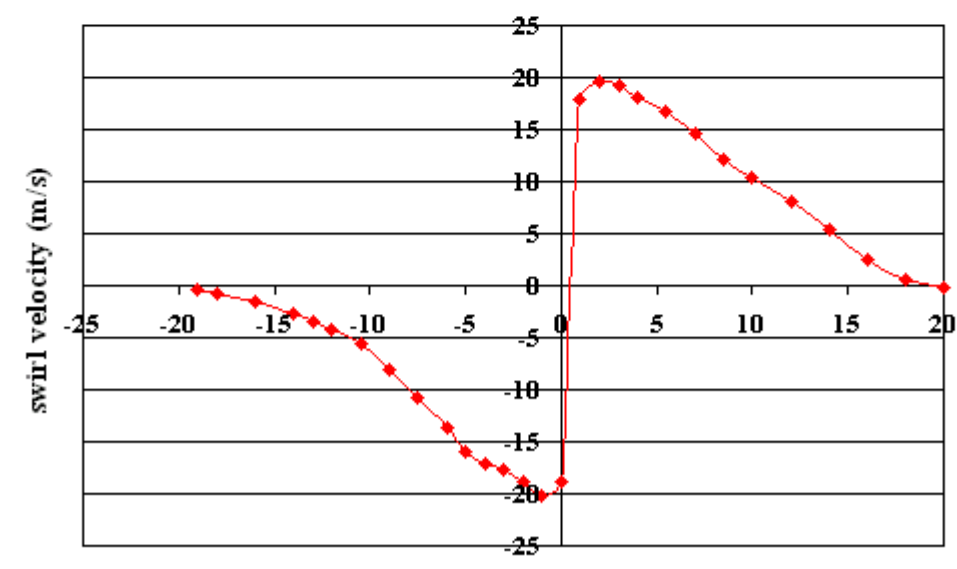

distance from the centerline (mm)

Figure 3 Example LDV velocity measurement results with a European blue flame burner. Top chart - $5 \mathrm{~mm}$ from nozzle. Bottom is swirl velocity $3 \mathrm{~mm}$ from nozzle 
The current BNL LDV capability includes measurements under cold (non-burning) conditions. To enhance this capability we would like to also be able to make measurements under actual, firing conditions. During this past year BNL management has made a decision to invest internal lab funds to add this capability to our laboratory. This new capability requires a dedicated lab, with laser safety controls, combustion capability and exhaust. This has recently been completed, cold tests have been done, and hot tests are starting. Figure 4 provides a illustration of the system which includes a rectangular, transparent quartz combustion chamber. The combustion chamber walls must be flat to enable the laser beams to pass into the combustion zone. Our expectation is that this new capability will help with the goal of achieving dramatic NOx reductions with practical burners.

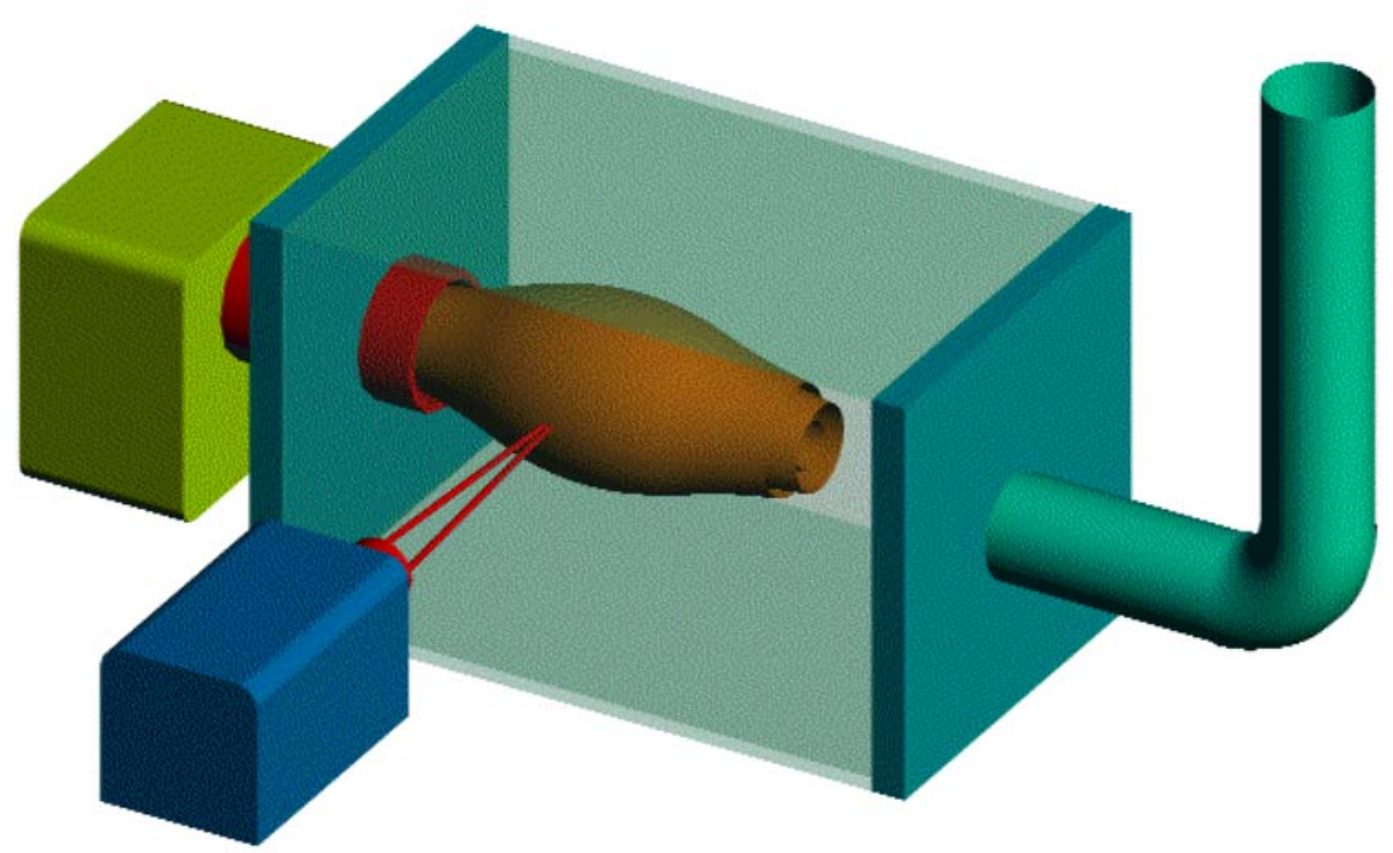

Figure 4 Sketch of new facility for direct laser measurement of velocity fields in oil burner flames.

The information produced by the spray measurements, cold air velocity fields, and even the hot gas laser measurements can provide critical input to another tool being used at BNL - Computational Fluid Dynamics (CFD) simulations of combustion. BNL is continuing to use a commercial code (Fluent) which can simulate oil drop movement in the flame zone, drop vaporization, combustion, recirculation, and emissions. 
Studies are being done in the BNL lab now to evaluate NOx levels which are achievable with ultralow nitrogen content fuels. The fuel currently being used is the ultralow sulfur content fuel for the condensing boiler project above. Studies with the BNL FanAtomized Burner, configured for very low NOx have been done and here levels of about 24 ppm have been achieved. With the blue flame European burner, operating in the condensing boiler (see above) levels under $20 \mathrm{ppm}$ have been measured. Clearly the goal of sub-20 ppm included in the Roadmap, seems achievable.

Another approach towards ultralow NOx, which is receiving considerable attention in Europe, involves vaporization and partial oxidation of fuel oil, followed by either a surface burner or a more conventional flow stabilized burner. Results reported to date have indicated that this may be a route to much lower NOx emissions. At present BNL is preparing to conduct some exploratory studies on this concept. The work involves a very narrow spray angle version of the fan atomized burner nozzle and a controlled temperature flow reactor. Our work will focus on analysis of fuel vapor composition after the low temperature, partial oxidation stage. A detailed plan for analysis via gas chromatography in cooperation with another BNL group has been established. There is also interest in the application of these concepts for oil-fired fuel cells.

Another area in which a strong new capability has been added to the BNL lab is in microturbines. At present 2 microtubines have been installed. One is gas-fired and has been integrated with the lab building heating system under sponsorship from the DOE Federal Energy Management Program. The other is oil-fired and emissions and efficiency studies are reported on in another paper at this conference.

During 2001 a very important project was started with NORA sponsorship on fuel quality. The overall goal of this problem is to understand and solve service problems related to instability, sludge formation, filter, and nozzle fouling. This work is ongoing with very interesting results to date and is also the subject of another paper at this conference. To support this work some capabilities are being added to the BNL lab in the area of field sampling and stability measurement equipment.

A major effort under this project involved the manual sampling of fuels oils at four retail distributors located in the northeast and mid-Atlantic regions. This was accomplished through a cooperative effort between the companies and BNL in order to collect fuels from the bulk terminals, barges, and customer tanks. The goal is to provide a first characterization of the physical and chemical properties of the fuels found in actual field conditions. With NORA funds, sampling equipment (Bacon bomb, Bottle cage, and zone samplers) was purchased to allow for collection of line samples, bulk samples, and tank bottom samples.

BNL had added both field and in-house lab capabilities to conduct simple, bench-top measurements for various fuel properties and contaminants. These include tank bottoms sediment and water (BS\&W) by centrifugation, detection of copper corrosion by the copper strip tarnish test, and microorganism contamination using field test kits. One of the most significant additions to the fuels characterization lab is the capability to assess 
distillate fuel storage stability by oxygen overpressure. This test for storage stability stresses the fuel samples in a high temperature, high pressure, and oxygen-rich environment. Fuel samples are then analyzed gravimetrically for particulate formation resulting from the oxidation of the oils under this accelerated ageing process. The results of this test method are useful in ranking various fuel samples for the tendency to form insoluble materials, and the relative effects of stabilizing additives under these lab conditions. One of the objectives under this NORA project is to determine how to correlate fuel instability with service problems. The Naval Research Lab (Washington, D.C.) has a lot of expertise in the development and use of storage and thermal stability tests for Navy distillate fuels, and BNL is collaborating with them on studies involving our heating fuels. As No.2 heating fuels have very similar characteristics to the Navy specified fuels intended for use on shipboard boilers, this collaborative effort involves sharing of fuel samples for analyses and data exchange.

Another area which is receiving considerable attention at present is the use of liquid biofuels for boilers applications. A project was completed in 2001 on the use of Biodiesel in space heating applications by testing blends with home heating fuel. This work was sponsored by DOE through the National Renewable Energy Laboratory. Tests in both a residential and the commercial boiler demonstrated the feasibility of switching from the \#2 fuel to a low level blend such as B20 (20\% biodiesel) without any changes to the system. One somewhat surprising result was that there were reductions in NOx emissions with blends, especially in the commercial boiler that was used in the tests. We are continuing this effort with NYSERDA funding with a field study, where a fuel oil dealer has been supplying a B20 blend to about a hundred homes since the beginning of the last heating season. Another study with NYSERDA funding through another New York State Fuel oil dealer will identify cheaper liquid biofuels for blending in No. 2 and No. 6 oils for large commercial and light industrial applications. Laboratory and field tests will be carried out with these blends as well.

In another project the BNL team is working with a manufacturer in Connecticut to develop an integrated microvalve / pressure atomizing nozzle. Opening and closing the valve at high frequency, with a pulse width modulated controller may enable full modulation of conventional, pressure atomized oil burners. Results to date have shown that good atomization quality can be maintained with a $2: 1$ turndown ratio.

In another project related to integrated thermal technologies, BNL is planning tests on a direct oil-fired absorption chiller system, which might be used to provide residential air conditioning. This prototype unit is coming from China. Our test plans include detailed thermal performance and emissions with a low NOx burner installed.

In another project BNL is involved in the development of an oil burner system with far lower electric power consumption than convention equipment. The most active work on this project at the present time involves the development of a control which will manage power flow. This is being done not at BNL but by Insight Technologies, Inc. When they complete a fieldable prototype it will be integrated with the burner developed at BNL for testing. Commercial development of the burner is being done by Heat Wise, Inc. With 
this same team BNL is also working on the development of a two-stage version of the Fan-Atomized Burner concept.

\section{Summary}

The past year has seen some significant changes in the BNL program with new directions and the additions of some exciting new capabilities. Overall, the BNL internal research program is supporting the industry driven Roadmap in many different ways. In the future the program at BNL will continue to evolve and, in accordance with the Roadmap and program plan, will include more direct industry involvement through subcontracted research and development projects.

\section{References}

1 R. Krajewski, Celebi, Y., Coughlan, R., Butcher, T., and McDonald, R. Emissions Characteristics of Modern Oil Heating Equipment, BNL-52249 (July 1990).

2. Butcher, T.A., Lee, S.W., Celebi, Y. and Litzke, W. Fouling of heat-transfer surfaces in oil-fired boilers for domestic heating, Journal of the Institute of Energy, 70, pp151159 (1997).

\section{Acknowledgments}

The BNL team would like to acknowledge the critical sponsorship received for this work from: 1) the U. S. Department of Energy, Office of Distributed Energy and Electric Reliability, Ron Fiskum Program Manager, 2) the New York State Energy Research and Development Authority, Ray Albrecht Program Manager, 3) the National Oilheat Research Alliance, and 4) internal BNL sponsorship on special projects. 


\author{
Paper No. 02-03 \\ Maximizing Fuel Quality and Heating System Performance \\ Wai-Lin Litzke and Yusuf Celebi, BNL \\ Dr. David Daniels, Octel Starreon, LLC \\ Building 526 \\ 12 North Six Street \\ Upton, NY 11973 \\ Phone: 631-344-7153 \\ Fax: 631-344-2359 \\ E-mail: wlitzke@bnl.gov \\ Internet: www.bnl.gov
}




\title{
Maximizing Fuel Quality and Heating System Performance Wai-Lin Litzke ${ }^{1}$, Dr. David Daniels ${ }^{2}$, and Yusuf Celebi ${ }^{1}$
}

\begin{abstract}
A stable fuel with consistent quality is essential for reliable, efficient operation of modern heating systems. One of the oil-heat industry's highest priorities is to reduce the unscheduled service calls that occur in between maintenance intervals. These no-heat calls, which can account for over $20 \%$ of the total number of service calls can be attributed to inconsistent fuel product, fuel degradation and contamination. There is very little information from the field correlating fuel properties with service needs. Analyses of fuel samples for specific properties provide information on the metals, sulfur content, filterability, thermal and oxidative stability and contaminant levels from bulk storage to end-user. The goal of this project is to understand the nature of fuel quality problems and to provide industry guidelines that will help to solve problems related to instability, sludge formation, filter, and nozzle fouling. This paper discusses the first year's effort, which began in 2001, on an in-depth study on burner fuels, sponsored by the National Oilheat Research Alliance (NORA).
\end{abstract}

\subsection{Introduction}

In cooperation with members of the oil-heat industry, Brookhaven National Lab began a new project on fuel quality. A major effort under this project involved surveying various retailers to identify the types of problems associated with poor fuel quality and to identify their magnitude. In order to accomplish this task it was necessary to gather service records from the company databases. Heating oil marketers from different regions in the Northeast and mid-Atlantic (VT, upstate NY, CT, PA, VA, NJ and Long Island NY) participated in the data collection. Unscheduled service calls were identified by "call reason" to include no-heat, no hot water, odors, soot, and smoke. The type of work done that might indicate a fouled fuel system include parts replacements (fuel pump strainer, oil filter, nozzle) or maintenance needs (cleaned oil line, flushed oil line). A selected group of service calls during January 2002, when the total number of calls were at their peak, revealed that fuel system failure (fouling) rates ranged from 10-23\% of the total unscheduled calls.

A major effort under this project involved the manual sampling of fuel oils at four retail distributors located in the states of CT, PA, and VA. This effort was accomplished with much cooperation from the companies, the analytical laboratory, and BNL in order to collect fuels from the bulk terminals, barges, and customer tanks. The goal was to provide a snapshot, and

\footnotetext{
${ }^{1}$ Brookhaven National Laboratory

${ }^{2}$ Octel Starreon, LLC
} 
characterization of the physical and chemical properties of the fuels found in the field. With NORA funds, sampling equipment (Bacon bomb thief samplers, bottle cage samplers, and zone samplers) was purchased to allow for collection of line samples, bulk samples, and tank bottom

samples. The following sections document the findings and conclusions that could be made from these preliminary results.

\subsection{What are the major factors that degrade fuel?}

In a concise paper, E. White [1] summarized all of the relevant mechanisms of fuel degradation that could contribute to sediment formation. The mechanisms may be categorized into the following:

a. Chemistry of the fuel - sediment formation from

- oxidation of organics, thermal effects

- sulfur/nitrogen compounds

- corrosion (iron oxides, copper)

- gels (mercaptan-copper)

- incompatible fuels

b. Microbiological effects

c. Tank and its environment- moisture, fuel circulation due to temperature differences

d. Lack of tank maintenance and poor design that may prevent adequate tank inspection, withdrawal of water and sediment, filtration, corrosion protection

Each of the above mechanisms were methodically examined to determine how important these parameters were in causing filter and nozzle plugging. As such, the fuel samples were analyzed specifically for thermal and storage stability using various test methods, adherent insolubles, color, total particulate matter, copper corrosion, soluble water, sulfur content, metals, contaminants in the bottom samples (bottom sediment \& water), and microbiological growth.

\subsection{How stable are the No. 2 fuels surveyed at the retail terminals?}

Unstable fuels lead to particulate formation. Heating oil can be unstable when stored for extended periods of time, such as 6 months to 1 year or longer. Test methods are available to measure the fuels inherent storage stability. The total volume of heating oil in tanks is usually not entirely turned-over with fresh fuels continually added to older fuels. In practice, fuel tanks may also be "topped" off at the end of the heating season with fuels sitting in tanks through the summer.

Thermal stability is a critical parameter to consider for applications where fuels are subjected to thermal stress, for example when the oil is used also as cooling fluid (typical in diesel engines). Premature fuel filter plugging by certain diesel fuel users have been attributable to poor thermal stability [2]. For oil burners, Kuchen and Haase (IWO) [3] have also attributed coke formation on preheater and oil nozzles to thermal decomposition of the fuel oil. Accelerated aging of fuel, using prescribed laboratory test methods, is done by the petroleum refining industry to determine 
the inherent thermal stability and oxidative (or storage) stability. For the purpose of quality control industry specifications typically site those methods that provide quick turn-around for results. For example, Colonial Pipeline, NYMEX (New York Harbor No. 2 Heating Oil, MILspec) may specify the following:

- (Thermal) D6468 (150 oC/ 300 oF, 90 min), Pad rating 7 or $70 \%$ Reflection minimum

- (Oxidation) D2274 (O2 bubbling, $16 \mathrm{hrs}$ ), $2.5 \mathrm{mg} / 100 \mathrm{ml}$ max.

- (Oxidation, Navy) D5304 (O2 high pressure, 16 hrs), $1.5 \mathrm{mg} / 100 \mathrm{ml}$ max.

Since 1993, there have been requirements to reduce the sulfur content in No. 2 distillate fuels used for highway vehicles in order to improve air quality. Hydrotreating is the main refining process used to lower sulfur and aromatic contents of middle distillate (No. 2 diesel or heating oil) fuels. Severe hydrotreating to obtain ultra-low sulfur levels $(<15 \mathrm{ppm})$ also removes all of the nitrogen components. Sulfur and nitrogen compounds in the fuel contribute to oxidation reactions that lead to sediment formation and fuel degradation. These factors affect the fuels' thermal stability [3]. Existing data in the literature shows that low-sulfur fuels have improved storage stability, and that stability remains excellent with greater hydrotreating [4-5].

A survey was done of four retailers from different regions with different fuel oil supply sources. Fuel composition varied mostly in terms of sulfur content. Table 1 and Figure 1 show the results of the thermal and storage stability properties, respectively, of the fuels. It is commonly accepted that from the point of production at the refinery there is the tendency for the fuel to degrade as it is commercially transported downstream. This survey also examined the thermal stability of the fuels trucked directly from the pipeline terminal and those barged from the New York Harbor.

The findings here show that most of the fuels supplied to the various retailers (from the barge, bulk tanks, or transporter trucks) meet the acceptable criteria for thermal stability ( $70 \%$ reflection). In addition, the results support the existing data which show improved stability properties with low-sulfur fuel. In fact, the ultra-low sulfur fuel with virtually no total nitrogen, at $11 \mathrm{ppm}$ of sulfur, rated the highest in terms of the thermal stability measurement. Unfortunately, this test fuel (undyed) is not yet commercially available. The results show that the fuels transported directly from the pipeline terminals appear to show better thermal stability ( $>80 \%$ reflectance) than those fuels received by barge ( $<80 \%$ reflect.). This suggests that instability of heating oil may be due to the greater amount of time barged fuels remain in transit and the potential for contamination with added handling and storage. 


\begin{tabular}{|c|c|}
\hline Sample Location - Description & $\begin{array}{c}\text { Thermal Stability D6468 } \\
\left(150{ }^{\circ} \mathrm{C}, 90 \mathrm{~min}\right) \\
\% \text { Reflectance }\end{array}$ \\
\hline \multicolumn{2}{|l|}{ Two (2) sites in CT-heating oil barged from NY Harbor } \\
\hline \multicolumn{2}{|l|}{ (1) Avg. sulfur $0.160 \% \mathrm{~S}$, Avg. gravity $31.1^{\circ} \mathrm{API}$} \\
\hline Retailer Bulk Tank (3/04/02) & 63.9 \\
\hline Retailer Bulk Tank (3/13/02) & 69.3 \\
\hline Retailer Bulk Tank (3/22/02) & 86.0 \\
\hline \multicolumn{2}{|l|}{ (2) Avg. sulfur $0.179 \% \mathrm{~S}$, Avg. gravity $32.9^{\circ} \mathrm{API}$} \\
\hline Fuel taken from barge from NY Harbor (3/12/02) & 72.6 \\
\hline Retailer Bulk Tank (3/04/02) & 74.9 \\
\hline Retailer Bulk Tank (3/21/02) & 73.9 \\
\hline \multicolumn{2}{|l|}{ Site in $V A$ - low sulfur dyed diesel from pipeline terminal } \\
\hline \multicolumn{2}{|l|}{ Avg. sulfur $0.035 \% \mathrm{~S}$, Avg. gravity $35.0^{\circ} \mathrm{API}$} \\
\hline Transporter \#213 (3/25/02) & 90.8 \\
\hline Transporter \#804 (3/25/02) & 87.5 \\
\hline Transporter \#213 (3/26/02) & 91.3 \\
\hline \multicolumn{2}{|l|}{ Site in $P A$ - heating oil from pipeline terminal } \\
\hline Transporter 901 & 90.4 \\
\hline Transporter \#2 & 89.7 \\
\hline Ultra-low sulfur diesel $\left(0.0011 \% \mathrm{~S}, 40.6^{\circ} \mathrm{API}, 1\right.$ ppm Nitrogen $)$ & 98.8 \\
\hline
\end{tabular}

Table 1. Thermal Stability of No. 2 Fuel Oil Samples Received at Various Retailers 
Storage Stability of Fuels Received at the Retailers- D4625 (13 weeks, 43 C)

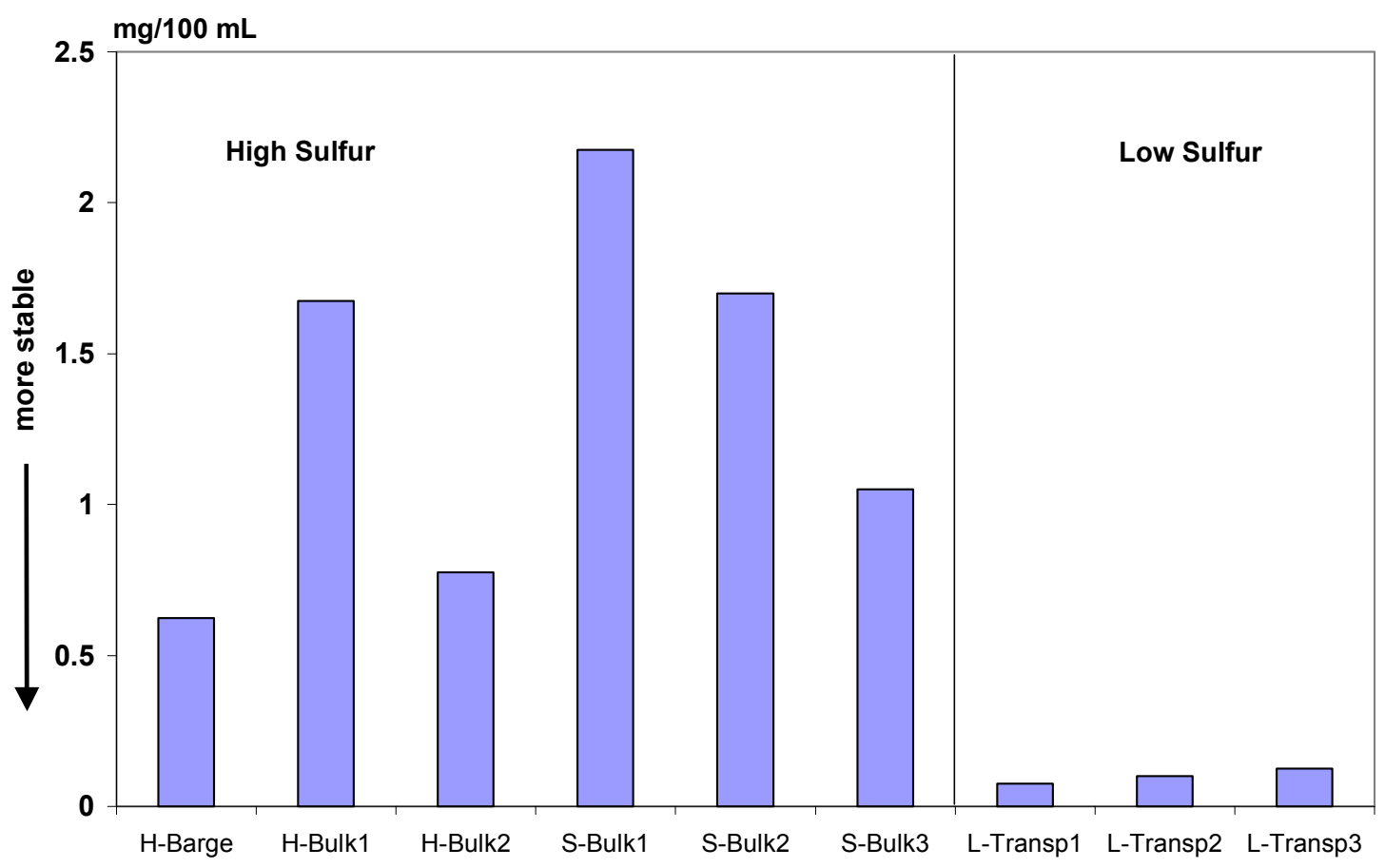

Figure 1. Storage Stability of Fuels Received at the Retailers (13 weeks, $\left.43{ }^{\circ} \mathrm{C}\right)$

\subsection{What are properties of the fuels in the customers' tanks?}

Once the fuels are delivered to the customers' tanks, the effects from the tank environment on fuel quality and the effects of mixing with existing fuels become very complex. Many factors can cause fuels to degrade forming sediment and sludge including contaminants such as water bottoms, microbiological growth, and metals. A sampling of more than 35 customer tanks indicated that some of the problems that led to repeated service calls was attributable to high water content, as determined by the amount of bottoms sediment and water (BS\&W) or waterindicating paste on stick. Water can cause heavy infestations of bacteria, fungus, yeast or mold, which causes filters to clog. A simple, field test kit (Liqui-Cult manufactured by MCE Chemicals and Equipment Co.) was used to detect and determine the amount of microbial growth in the bottom samples. A small portion of sample was injected into the growth medium and allowed to incubate for 30 hours to determine bacterial growth, and 72 hours for fungal growth. This procedure done immediately in the field reduces the risk of external contamination, which in turn would lead to inaccurate results.

The results of all the field measurements with a description of the test sites and their service histories, where available, are provided in the Appendix. Although there can be detectable amounts of contamination in tank bottoms this does not necessarily lead to burner shut-down. 
Depending on factors like the fuel filtration system, nozzle size (or firing rate), total particulates suspended in the fuel, the system may operate with different maximum limits of contamination.

Fuel samples from the retailer and customer tanks were analyzed in the laboratory for corrosivity to copper (ASTM D130), metals using ASTM D5185, and trace amounts of copper using flame atomic absorption. These tests were used to determine whether existing problems could be associated with copper piping typically used for fuel supply and return lines. The results from all of the fuel samples showed no significant amount of metals down to the parts per billion detection limit and that the fuels are not corrosive to copper. Total particulate concentrations measured in the fuel samples were on average highest in the customer tanks, at up to $57 \mathrm{mg} / \mathrm{L}$. Samples from the retailer bulk tanks and transporter trucks were generally below $10.0 \mathrm{mg} / \mathrm{L}$. Monitoring for potential contaminants in the delivery trucks is critical so as not to deliver contaminants to a whole population of customer tanks.

\subsection{What are the effects of chemical additives used to stabilize the fuels?}

As part of this study, fuel samples treated with antioxidant (or stabilizer) additives were tested for thermal stability at high temperature of $150{ }^{\circ} \mathrm{C}$ for 90 minutes and 180 minutes, and compared with the untreated samples. Figure 2 shows the results for the more stressful test at $180 \mathrm{~min}$. for two retail sites- one using typical heating oil and one using low sulfur product. The differences in the $90 \mathrm{~min}$. test were less pronounced.

The results suggest that chemical treatment of already highly stable fuels ( $\sim 90 \%$ reflectance $)$, such as the low-sulfur product, did not significantly change the thermal characteristics of the untreated, base fuel. For the untreated heating oil, which showed lower thermal stability at this temperature, chemical treatment improved or maintained the stability of this fuel.

\subsection{Do fuels degrade in the customers' tanks?}

Thermal and storage stability can degrade markedly in fuels downstream at the customer tanks. Figure 3 shows a comparison of the thermal stability at $150{ }^{\circ} \mathrm{C}$ and $90 \mathrm{~min}$ for fuels sampled at a heating oil distributor and at the customers' tanks. This trend is also evident when we analyze the fuels for long-term storage stabilities using D4625 and oxidation stability (D5304). 
Thermal Stability $180 \mathrm{~min}$, at $150^{\circ} \mathrm{C}$

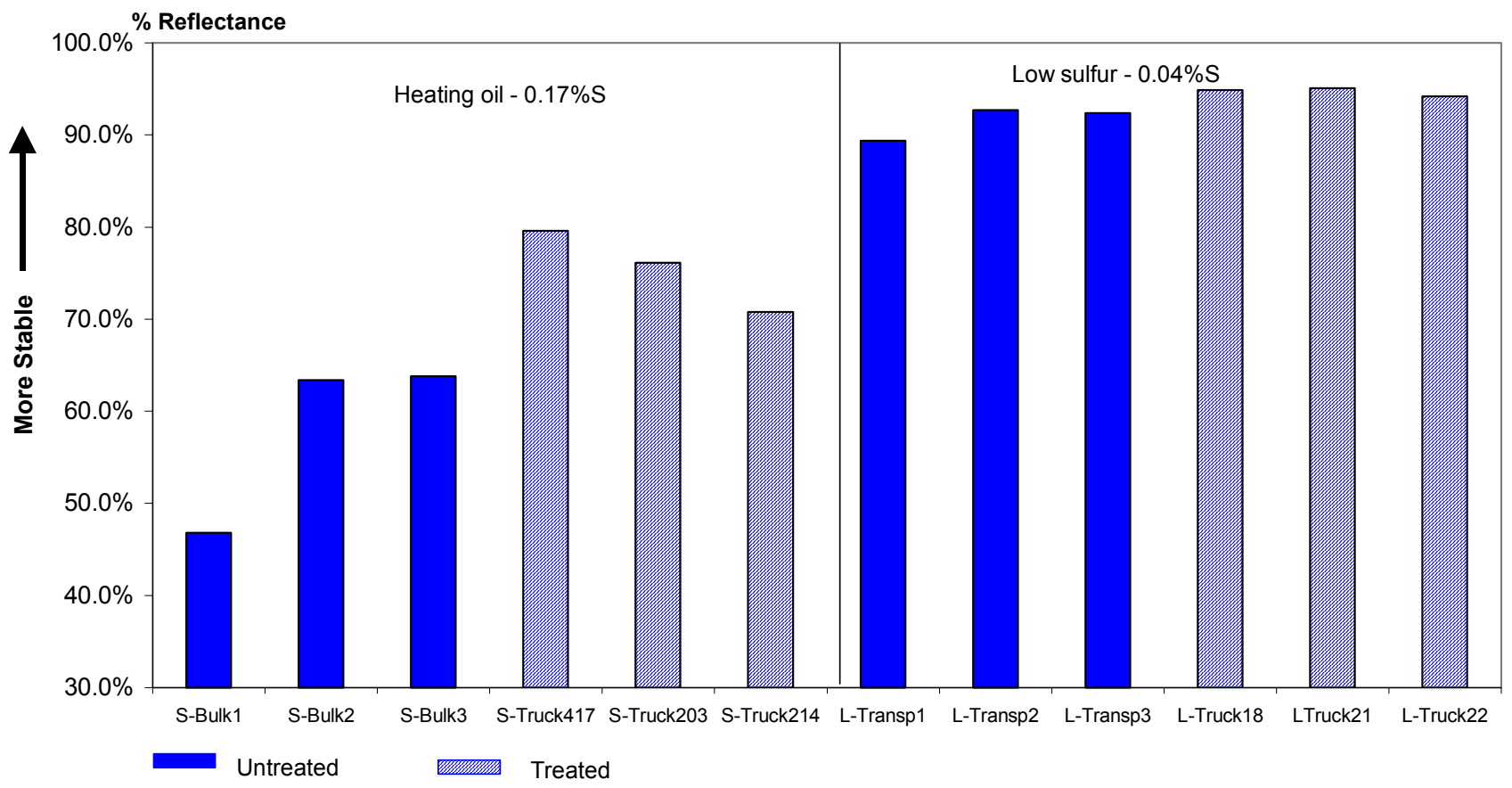

Figure 2. Thermal stability for heating oil and low sulfur diesel $\left(180 \mathrm{~min}, 150^{\circ} \mathrm{C}\right)$ 


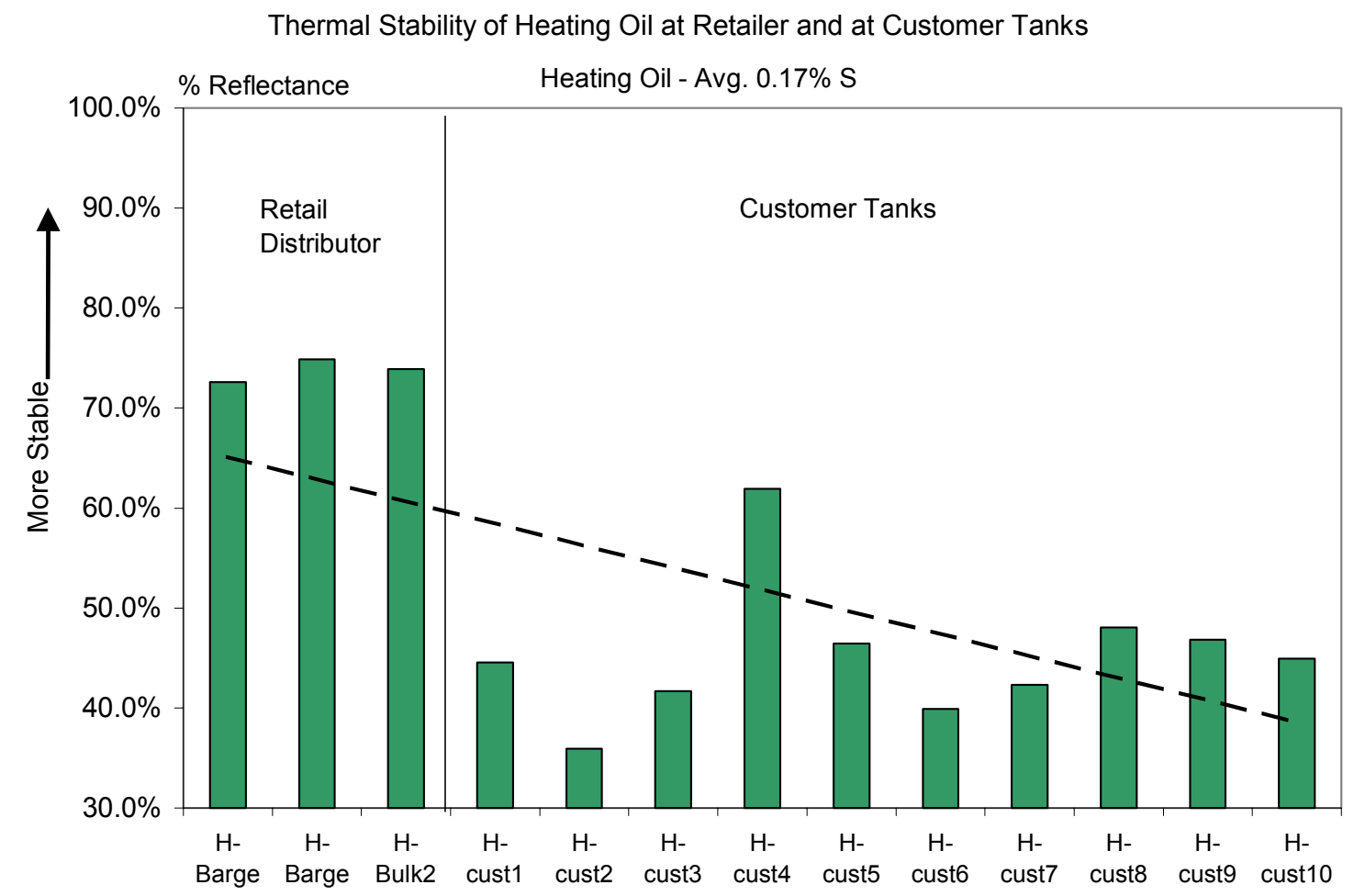

Figure 3. Comparison of thermal stability $\left(150{ }^{\circ} \mathrm{C}, 90 \mathrm{~min}\right.$. $)$ of fuels supplied by distributor and in customer tanks.

\subsection{Conclusions}

The findings of this survey indicate that contamination in the customer tanks is the leading cause of sediment (sludge) build-up, filter plugging and burner shut down. Insoluble particulates produced from unstable fuels also contribute to sediment formation.

The solutions to improving fuel performance and reducing service calls must be a multi-pronged approach. One must consider the following:

- Fuel chemistry - Stable fuels at the supply source are needed to maintain fuel quality downstream in the customer tanks. Refining processes that are being used to reduce the fuel's sulfur content help to improve its stability. The ultra-low sulfur product exhibits excellent stability characteristics due to the lack of reactive nitrogen- and sulfur- containing compounds. For less stable fuels, the use of antioxidant stabilizing additives upstream may help to improve or maintain its stability.

- $\quad$ Preventative maintenance is the key to minimizing filter plugging problems. Simple tests are available for field use to detect significant amounts of water, or microbial 
growth that could plug filters. Tank inspection and tank design must allow for periodic water removal. Biocide treatment may be needed in cases where there is severe microbial infestation.

\subsection{References}

[1] White, E., IASH 2000, $7^{\text {th }}$ International Conference on Stability and Handling of Liquid Fuels, Graz, Austria, Sep. 24-29, 2000, p. 717.

[2] Bacha, J. and Lesnini, D., "Diesel Fuel Thermal Stability at $300{ }^{\circ} \mathrm{F}, " 6^{\text {th }}$ International Conference on Stability and Handling of Liquid Fuels, Vancouber, Canada, Oct. 13-17, 1997, pp. 671-684.

[3] Kuchen, C. and Haase, F. (IWO), "Development of Heating Oil Quality Considering Ecological, Economic, and Technical Aspects, VDI Conference on Oil Burner Technology for Very Low -Firing Rates, Hannover, Germany, Jan. 2002.

[4] Green, J. B., Stirling, K. Q., Ripley, D. L., and Vanderveen, "The Effects of Moderate to Severe Hydrotreating on Diesel Fuel Properties and Performance," $6{ }^{\text {th }}$ International Conference on Stability and Handling of Liquid Fuels, Vancouber, Canada, Oct. 13-17, 1997, pp. 629-648.

[5] Waynick, J. A., "Effect of Increasingly Severe Hydrotreating on Stability-Related Properties of No. 2 Diesel Fuel," $6^{\text {th }}$ International Conference on Stability and Handling of Liquid Fuels, Vancouber, Canada, Oct. 13-17, 1997, pp. 649-648.

\section{ACKNOWLEDGEMENTS:}

The authors wish to thank the participants of the NORA Fuel Performance Committee, the petroleum marketers, the service managers and technicians, equipment manufacturers, and the researchers for their dedication and assistance on the progress of this NORA project. 


\section{APPENDIX}

Survey of Customer Tanks- Field Observations 


\begin{tabular}{|c|c|c|c|c|c|c|}
\hline Location & Sample appearance & Service issues & $\begin{array}{l}\text { BS\&W \% } \\
\text { vol }\end{array}$ & $\begin{array}{l}\text { Water,in. } \\
\text { paste }\end{array}$ & Bacteria & $\begin{array}{l}\text { Fungus, Yeast \& Mold } \\
\text { (Field Test Kit) }\end{array}$ \\
\hline H-cust1 & & No service history available & $<0.05$ & ND & neg & slight \\
\hline $\mathrm{H}$-cust2 & & No emergency calls & $<0.05$ & ND & slight & slight \\
\hline H-cust3 & $\begin{array}{l}\text { Bottom sample dark } \\
\text { grey; line sample } \\
\text { looked clear, felt filter } \\
\text { clean (last changed } \\
11 / 01 \text { ) }\end{array}$ & $\begin{array}{l}\text { No-heat } 12 / 01 \text { repair oil line, replaced pump; } \\
\text { No heat } 11 / 01 \mathrm{CO} 2 \text { charges, replaced filter; } \\
\text { last cleanings } 5 / 00,8 / 99 \mathrm{CO} 2 \text { charges }\end{array}$ & 4.00 & ND & slight & slight \\
\hline H-cust4 & & $\begin{array}{l}\text { New tank installed } 6 / 00 \text {; no-heat calls } 11 / 01 \\
\text { replaced motor; } 11 / 01 \text { wiring, } 12 / 00 \text { replaced } \\
\text { nozzle, burner parts, } 11 / 00 \text { replaced nozzl, no- } \\
\text { heat } 4 / 01 \text { replaced primary control }\end{array}$ & $<0.05$ & ND & slight & slight \\
\hline H-cust5 & $\begin{array}{l}\text { Felt filter contained } \\
\text { thick sludge on } \\
\text { cartridge }\end{array}$ & $\begin{array}{l}\text { Call } 2 / 02 \text { running on arrival, replaced nozzle, } \\
\text { adjust burner; last cleaning } 7 / 01 \text { replaced } \\
\text { pump strainer, nozzle, filter. }\end{array}$ & 1.40 & ND & slight & slight \\
\hline H-cust6 & $\begin{array}{l}\text { Filter and line sample } \\
\text { looked clear }\end{array}$ & $\begin{array}{l}\text { Odor call } 10 / 00 \text { replaced nozzle; no hot water } \\
5 / 00 \text { replaced nozzle, adj. electrodes; } \\
\text { cleaning } 4 / 00 \text { replaced nozzle, filter }\end{array}$ & $<0.05$ & ND & slight & slight \\
\hline H-cust7 & $\begin{array}{l}\text { Bottoms lots of water, } \\
\text { yellow fuel }\end{array}$ & $\begin{array}{l}\text { Existing sludge problem, shuts off burner } \\
\text { before fuel delivery, no-heat } 2 / 02 \text { after } \\
\text { delivery, } 11 / 00 \text { improper operation, filters } \\
\text { replaced, } \mathrm{CO} 2 \text { charges }\end{array}$ & 100 & 1.5 & slight & heavy \\
\hline H-cust8 & & $\begin{array}{l}\text { Serviced only when system has operational } \\
\text { problems; no heat calls } 11 / 01,2 / 00,11 / 98 \\
\text { each time replacing filter, nozzle, pump } \\
\text { strainer }\end{array}$ & 15 & 0.5 & heavy & heavy \\
\hline H-cust9 & $\begin{array}{l}\text { Bottom sample high } \\
\text { particulate } \\
\text { loading,felt filter looks } \\
\text { clean }\end{array}$ & No fuel related calls & 3.00 & ND & slight & moderate \\
\hline $\mathrm{H}$-cust10 & & $\begin{array}{l}\text { Some fuel-related problems; } 3 \text { no-heat calls } \\
\text { and } 1 \text { cleaning in } 10 / 01 \text {, cleaning } 1 / 01 \text {, } \\
\text { smoke/fumes } 7 / 00,2 \text { calls } 9 / 99-10 / 99 \text {. }\end{array}$ & 99.5 & 1.5 & moderate & ND \\
\hline
\end{tabular}

\begin{tabular}{|c|c|c|c|c|c|c|}
\hline Location & Sample appearance & Service issues & $\begin{array}{l}\text { BS\&W \% } \\
\text { vol }\end{array}$ & $\begin{array}{l}\text { Water,in. } \\
\text { paste }\end{array}$ & Bacteria & $\begin{array}{l}\text { Fungus, Yeast \& Mold } \\
\text { (Field Test Kit) }\end{array}$ \\
\hline S-cust1 & $\begin{array}{l}\text { Bottoms dark grey, } \\
\text { heavy sediment }\end{array}$ & No service history avail. & 20.0 & 1 & slight & heavy \\
\hline S-cust2 & & No fuel problems & 0.07 & ND & slight & \\
\hline S-cust3 & Bottom sample clear & No fuel problems & 0.02 & ND & neg & slight \\
\hline S-cust4 & Bottoms dark & No service history avail. & 7.00 & 0.25 & mod-heavy & heavy \\
\hline S-cust5 & & $\begin{array}{l}\text { No significant fuel problems;no-hot water } \\
11 / 01 \text { adj. ignitors, } 12 / 01 \text { placed can of 'hot' in } \\
\text { oil tank }\end{array}$ & 18.0 & 0.25 & slight & heavy \\
\hline S-cust6 & & $\begin{array}{l}\text { No significant fuel problems; no-heat in } \\
3 / 23 / 00 \text { replaced relay, nozzle; no heat } \\
3 / 14 / 00 \text { replaced burner motor, pump, nozzle } \\
\text { line }\end{array}$ & $<0.05$ & ND & neg & neg \\
\hline S-cust7 & $\begin{array}{l}\text { Bottoms dark, filter } \\
\text { was very dirty }\end{array}$ & $\begin{array}{l}\text { No-heat calls (5 in last } 2 \text { yrs.); tank cleaning, } \\
\text { sludge problem }\end{array}$ & 1.10 & 0.125 & neg & slight \\
\hline S-cust8 & & No fuel problems & 0.05 & ND & neg & slight \\
\hline S-cust9 & Bottoms clear & No fuel problems & $<0.05$ & ND & neg & neg \\
\hline S-cust10 & & No fuel problems & $<0.05$ & ND & neg & neg \\
\hline L-cust1 & $\begin{array}{l}\text { Bottom sample with } \\
\text { lots of sediment }\end{array}$ & No fuel related calls, $6 / 94$ cleaned fuel tank & 1.00 & ND & slight-mod & \\
\hline L-cust2 & $\begin{array}{l}\text { Sample taken after } \\
\text { pump strainer }\end{array}$ & $\begin{array}{l}3 / 02 \text { Odors; } 9 / 01 \text { PMl; } 1 / 01 \text { No-heat, nozzle } \\
\text { fouled, installed new nozzle; } 1 / 01 \text { no-heat } \\
\text { replaced nozzle; } 9 / 00 \text { new tank installed }\end{array}$ & $<0.05$ & ND & neg & neg \\
\hline L-cust3 & $\begin{array}{l}\text { Sample taken after } \\
\text { pump strainer }\end{array}$ & $\begin{array}{l}\text { No fuel related problems; } 5 / 00 \text { new tank } \\
\text { installed }\end{array}$ & 4.50 & 0.125 & moderate & \\
\hline L-cust4 & $\begin{array}{l}\text { Fuel line was } \\
\text { clogged; sample was } \\
\text { taken when oil line } \\
\text { was cleared using } \\
\text { hand piston pump }\end{array}$ & $\begin{array}{l}\text { Odors 9/01, 8/01 PMI, } 5 / 01 \text { no heat, CO } \\
\text { detector going off, } 12 / 00 \mathrm{PMl} \text {; new tank } \\
\text { installed } 8 / 00 \text { transferred } 225 \text { gallons of oil }\end{array}$ & 10.0 & 0.5 & slight & \\
\hline
\end{tabular}




\begin{tabular}{|c|c|c|c|c|c|c|}
\hline Location & Sample appearance & Service issues & $\begin{array}{l}\text { BS\&W \% } \\
\text { vol }\end{array}$ & $\begin{array}{l}\text { Water,in. } \\
\text { paste }\end{array}$ & Bacteria & $\begin{array}{l}\text { Fungus, Yeast \& Mold } \\
\text { (Field Test Kit) }\end{array}$ \\
\hline L-cust5 & $\begin{array}{l}\text { Heavy bottom } \\
\text { sediment } \& \text { water }\end{array}$ & $\begin{array}{l}\text { Tank bottom pump-out on } 3 / 02 ; 3 / 02 \text { no hot } \\
\text { water, replaced water valve; } 3 / 02 \text { water leak; } \\
2 / 02 \text { replaced thermostat; } 2 / 01 \mathrm{PMI} ; 1 / 01 \text { No } \\
\text { hot water, replaced vent, checked circulator; } \\
12 / 00 \text { No hot water, replaced vent; } 11 / 00 \text { No } \\
\text { hot water, checked water heater; } 11 / 00 \text { No } \\
\text { hot water, checked water heater, purged air; } \\
11 / 00 \text { No heat, checked thermostat, running } \\
\text { on arrival, unable to find any problems; } 7 / 00 \\
\text { water leak; } 3 / 00 \text { bled piping; } 3 / 00 \text { installed } \\
\text { vent; } 2 / 00 \text { No hot water, replaced valve, } \\
\text { backflow preventer was leaking water; }\end{array}$ & 100 & 3 & & \\
\hline L-cust6 & $\begin{array}{l}\text { Sample was taken } \\
\text { with piston pump } \\
\text { purged with tank fuel } \\
\text { before sample was } \\
\text { taken; hand pump } \\
\text { may have previous } \\
\text { contamination }\end{array}$ & $\begin{array}{l}\text { No fuel related problems; } 7 / 96 \text { new oil line; } \\
\text { fuel tank cleaned 10/93, fuel filtered }\end{array}$ & 2.00 & 0.5 & slight & \\
\hline L-cust7 & & $\begin{array}{l}\text { No fuel related problems going back to } 1994 \\
\text { with annual PMI }\end{array}$ & $<0.05$ & ND & neg & slight \\
\hline L-cust8 & $\begin{array}{l}\text { Fuel thief picked up } \\
\text { some "oily" } \\
\text { insolubles; bottom } \\
\text { sample looked darker }\end{array}$ & $\begin{array}{l}\text { No fuel related calls with new tank; 3/02 PMI, } \\
12 / 01 \text { new tank installed }\end{array}$ & 5.00 & ND & neg & none \\
\hline L-cust9 & & $\begin{array}{l}\text { 2//02 No-heat, replaced burner coupling; 2/02 } \\
\text { PMI; 3/01 PMI; } 1 / 01 \text { installed Tiger-loop; } 1 / 01 \\
\text { New tank installed }\end{array}$ & $<0.05$ & ND & slight & \\
\hline Location & Sample appearance & Service issues & $\begin{array}{l}\text { BS\&W \% } \\
\text { vol }\end{array}$ & $\begin{array}{l}\text { Water,in. } \\
\text { paste }\end{array}$ & Bacteria & $\begin{array}{l}\text { Fungus, Yeast \& Mold } \\
\text { (Field Test Kit) }\end{array}$ \\
\hline L-cust10 & $\begin{array}{l}\text { Bottom sample had } \\
\text { some sediment; fuel } \\
\text { thief picked up some } \\
\text { "oily" insolubles on } \\
\text { the surfaces; two line } \\
\text { samples were taken } \\
\text { unfiltered and filtered }\end{array}$ & $\begin{array}{l}\text { No fuel related problems; new tank installed } \\
10 / 00\end{array}$ & 2.00 & ND & neg & slight \\
\hline M-cust1 & $\begin{array}{l}\text { Bottom sample with } \\
\text { heavy sediment; } \\
\text { trace amounts of } \\
\text { gummy oil droplets }\end{array}$ & $\begin{array}{l}\text { No service history avail. Nozzle size } 4.5 \mathrm{gph} \text {, } \\
\text { top feed supply, felt filter }\end{array}$ & 4.00 & 1.2 & ND & heavy \\
\hline M-cust2 & & $\begin{array}{l}\text { No service history avail. Nozzle size 6-7 gph, } \\
\text { top feed, oil sits idle in tank for about } 6 \\
\text { months off-season }\end{array}$ & 2.36 & ND & moderate & heavy \\
\hline M-cust3 & & $\begin{array}{l}\text { No service history avail. Bottom feed, last } \\
\text { maintained 12/15/01 new felt filtercartridge } \\
\text { installed. }\end{array}$ & 0.04 & ND & ND & slight \\
\hline M-cust4 & $\begin{array}{l}\text { Traces of gum } \\
\text { deposits on fuel thief } \\
\text { sampler, sample } \\
\text { taken with filter } \\
\text { removed, through } \\
\text { pump strainer }\end{array}$ & $\begin{array}{l}\text { No service history avail. Nozzle } 1.0 \mathrm{gph} \text {, felt } \\
\text { filter; fuel oil is contantly recirculated- during } \\
\text { season pump runs } 24 \mathrm{hrs} / \text { day, high circulation }\end{array}$ & 28.0 & 0.4 & slight & heavy \\
\hline M-cust5 & & $\begin{array}{l}\text { No service history avail. Bottom feed, felt } \\
\text { filter replaced annually as part of in-house } \\
\text { maintenance as for all the other tanks }\end{array}$ & 2.10 & ND & ND & moderate \\
\hline M-cust6 & & $\begin{array}{l}\text { No service history avail. Bottom feed, felt } \\
\text { filter replaced annually as part of in-house } \\
\text { maintenance }\end{array}$ & 1.70 & ND & moderate & heavy \\
\hline
\end{tabular}


Paper No. 02-04

The Oilheat Industry Roadmap-

Toward a Sustainable Energy Future

Daniel Brewer

Energetics, Inc.

7164 Gateway Drive

Columbia, MD 21046

Phone: (410) 953-6289

Fax: (410) 290-0377

E-mail: dbrewer@energetics.com

Internet: www:energetics.com 


\section{The Oilheat Industry Roadmap- Toward a Sustainable Energy Future}

\section{$\underline{\text { Introduction }}$}

The oilheat industry is forming strategic partnerships with the U.S. Department of Energy (DOE) and Brookhaven National Laboratory (BNL) to make technological advancements that will reduce the cost and increase the efficiency of oilheat, both today and into the future. The oilheat industry is motivated to take a major step forward in regaining market share. The Petroleum Marketers Association of America (PMAA) and the newly formed National Oilheat Research Alliance (NORA) are facilitating working relationships throughout the oilheat industry and with government to make these goals a reality. High electricity prices, uncertain energy supplies, volatile natural gas spikes, and uneven electricity deregulation policies in the U.S., are opening the door for oilheat. It is time to cross the threshold into the 21 century.

The oilheat industry is in a compromised position. It markets a commodity over which it has limited control - of the source, quality, price, and availability. Yet, the industry has managed to be a clean, cost-efficient supplier of premium indoor comfort to over 10 million homes in the United States. The U.S. Department of Energy in partnership with leaders of the oilheat industry, have taken a further step forward in developing a vision and roadmap for research, development, and commercialization of new products and systems. The result of this effort is this document, the Oilheat Industry Roadmap- Toward a Sustainable Energy Future. The Roadmap provides a framework for recognizing both future challenges to the oilheat industry and opportunities for strategic public and private partnerships that will address these challenges through a set of specific actions, ultimately achieving the vision for the future.

\section{Background}

More than 10 million households in the United States use oil for space and water heating. It is a safe, economical, clean burning, and energy-efficient fuel. For over 50 years, oil has been the primary space and water heating fuel for homes, businesses, and schools in both Northeastern and Central Atlantic states.

Oilheat surfaced as a primary heating fuel in the 1940's and 1950's, replacing coal furnaces, which required daily attention and maintenance. At that time, oil was

Percentage of U.5. Households Using Heating OII

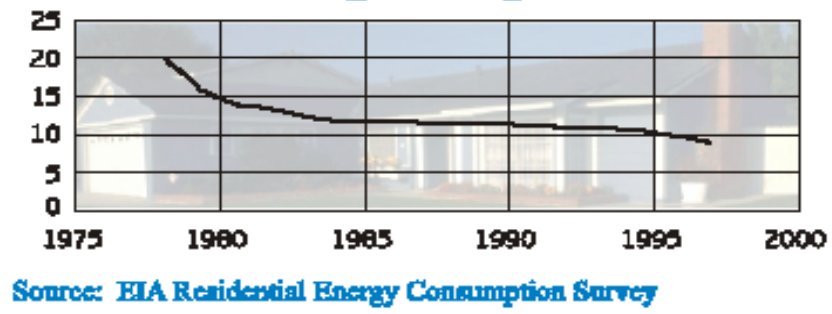
seen as a modern, clean alternative to coal, which was much more difficult to store, often generated noxious fumes, and resulted in ashes and cinder which homeowners had to dispose of manually. The combination of the Gulf oil crisis of the 1970's, aggressive marketing by the natural gas industry and the public's misconception of 
oilheat as old-fashioned and environmentally harmful, have all led to a gradual decline in the percentage of U.S. households using oilheat.

Oilheat offers consumers a product that compares favorably with other home heating options. Modern oil burners produce negligible amounts of smoke and soot. Oil burning appliances (furnaces, boilers, etc.) are typically $85 \%$ efficient or higher. Homeowners and building managers receive the most value when they choose oil as a heating fuel.

Not only is oil economical, efficient, portable, and relatively easy to store, it is also a very safe heating fuel. If an oilheat tank leaks, it is non-explosive. In addition, the risk of carbon monoxide exposure from the fuel is low. When a burner goes out of adjustment, oil generally generates smoke before high levels of carbon monoxide are released, alerting a homeowner or building manager of a potential problem. By contrast, it is impossible for building owners or managers to detect a carbon monoxide leak by simply looking at a natural gas or propane burner.

\section{Oilheat's Use in the Marketplace}

Heating oil is a middle distillate fuel; other middle distillates include kerosene, jet fuel, and highway diesel fuel. Refiners primarily produce heating oil in the winter, when demand is the highest. They can increase production to a modest degree; production levels then reach a point at which refiners may need to produce other petroleum products, which cannot be sold in sufficient quantities during those winter months. Thus, to help meet high winter demands, refiners build inventories in the prior summer and fall. However, if demand is high for another seasonal petroleum product, such as gasoline, refiners may delay production of heating oil, thus lowering inventories.

Refiners and importers ship heating oil by barge, tanker, rail, or pipeline into a central distribution area, such as New York Harbor, where it is then redistributed to wholesale terminal operations throughout the country. The product is then distributed by truck to local oilheat dealers for storage or sent directly to residential, commercial, and institutional consumers.

Heating oil is a highly seasonal fuel, used primarily in the October to March time period; in addition, homes and buildings that use oil for heating are primarily found in the Northeast, which includes New England and the Central Atlantic states. Of U.S. households that use oilheat, $69 \%$ are in the Northeast and account for $78 \%$ of 1999 residential heating oil sales.

Annual Res/dentlal Heating Oll Sales -1999

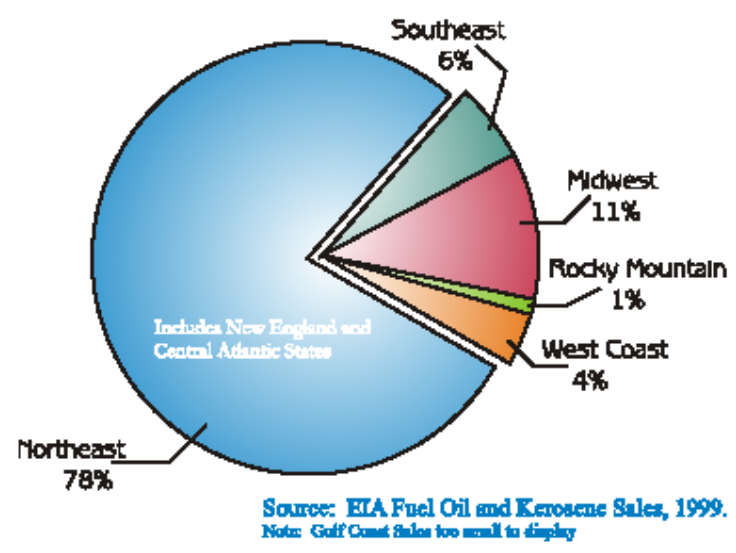

The oilheat industry's unique and significant advantage over electric and natural gas heating is that it has access to a worldwide refining infrastructure and is easily and economically transported. For example, in the Northeast, transportation costs comprise $20 \%$ of oil's total cost, versus $80 \%$ for natural gas. In addition, heating oil is inexpensive to store in large wholesale terminals, helping to offset peak winter demand. 
Across the country, oilheat is rarely installed in new home construction or in remodeled or renovated buildings. Eighteen percent of all new homes constructed before 1950 used oil as their main heating fuel; today that number has dropped to $4 \%$. This is due to the fact that builders have little interest in the heating system operating costs but are very sensitive to capital costs required to heat homes. In turn, utilities offer builders cash subsidies to install natural gas or electric heating systems, and these subsidies are almost always paid by the rate payer, not the stockholders. Unfortunately, this is a state-by-state issue regulated by state public service commissions. The oilheat industry has been unsuccessful in eliminating this subsidy.

\section{The Oilheat Industry Today}

The U.S. oilheat industry employs more than 160,000 workers, most of whom are trained and highly skilled technicians in over 6,000 small, highly competitive, familyowned businesses. These small oilheat marketers, distributors, and suppliers compete for customers against local gas and electric utilities, as well as each other. Due to this highly competitive market, oilheat suppliers provide a full range of professional, in-home services exclusive to oil heat companies - an important advantage for homeowners and building managers. Oilheat industry professionals take great pride in providing superior servicing of oilheat equipment. Whether it is the middle of the night or in below-freezing temperatures, servicemen are always available to diagnose and fix problems. Building on this customer service philosophy, the oilheat industry is striving to maintain and build their market share, as well as move into new niche markets.

The U.S. Department of Energy (DOE), in cooperation with oilheat marketers and equipment manufacturers, has, in past years supported improvements in the efficiency and technology of oil heating equipment. This cooperative relationship has led to tremendous advancements in the efficiency of oilheat equipment, saving consumers over $\$ 6$ billion and resulting in savings of $\$ 500$ for each $\$ 1$ invested in research and development.

In 2000, Congress recognized the need for increased research, development and demonstration (RD\&D), by passing the National Oilheat Research Alliance (NORA) Act of 2000, which created a national check-off program for the oilheat industry. Such check-off programs are voluntary, initiated and run by the industries that fund them. Implementing regulations are self-imposed and administered by members of the industry. Among the anticipated programs to be initiated with the oilheat funds, is collaborative research on oilheat technology enhancements, such as production of "clean oil" through the removal of sulfur and reduction of nitrogen, and improved transportation and storage. NORA and the Petroleum Marketers Association of America (PMAA) are facilitating a working relationship with leaders of the oilheat industry to enhance education and communication activities, and improve the public's perception of oilheat. 


\section{Forces Driving the Industry}

Many factors will determine the future of oilheat in the U.S. over the next twenty years - technological change, market forces, customer needs, environmental pressures, and regulatory and institutional issues.

\section{Technological Change}

New energy technologies are playing an important role in determining the future of the oilheat industry. Low NOx burners $(<50 \mathrm{ppm})$ allow oilheat to be as clean a heating option as any available and provide high equipment reliability. Two-stage burners improve efficiency, reduce cycling rates, and prolong the life of the oilheat system. Clean oil combustion technologies, such as the Fan Atomized Burner, are being developed to meet future environmental regulations and allow for integration of oilheat into total energy systems - heating, cooling, and power.

Information technologies are critical to all aspects of business. Smart technologies allow oilheat suppliers to manage their customers' heating systems more effectively. Many hours are already spent by technicians in diagnosing problems, but self-diagnostic equipment could be used to identify problems and cut back on service times. Flame quality monitors are being developed to notify customers when burners have to be serviced, instead of waiting for the system to fail.

In the future, technologies that supply heat as a byproduct of power will help oilheat penetrate the buildings cooling, heating, and power (BCHP) market. Oilheat thus will grow not only within the CHP market, but will help double CHP capacity to $92 \mathrm{GW}$ by the year 2010 .

Improved tank technology will allow systems to be more environmentally friendly. Customers will not be concerned about tank leaks and environmental and economic impacts associated with them. Tanks will reduce fuel contamination, be appropriately sized, visually pleasing to the homeowner or building manager, and will maintain efficient fuel delivery.

Poor fuel performance accounts for up to one-half of service calls. Additives can improve fuel performance characteristics and prevent accumulation of contaminates within fuel tanks. Additive research can improve choices and effectiveness.

Biofuels blended with distillate oil can provide a complete or partial substitute for oilheat when supplies are low. Biofuels are manufactured from vegetable oils, cooking grease, or animal fats and can be used in combination with distillate oil or as a pure renewable fuel. Many states offer tax credits for the use of renewable fuels. Currently biofuels are not exempt from federal and state taxes, but in the future biofuels may be recognized as "renewable fuels" and become eligible for tax incentives. The low sulfur content of biofuels will certainly meet future environmental regulations. 


\section{Market Forces}

The price of crude oil on the world market drives the price of heating oil. The cost of heating oil, compared to competitive fuels (e.g., natural gas, propane, electricity), drives its use in the marketplace. In areas of the U.S. where electricity and natural gas are transported short distances from the source of supply, they are preferred heating fuels. Electric baseboard systems usually have lower installed capital costs than oilheat systems, even though they are less energy efficient.

Although the residential sector is the primary market for oilheat, the commercial sector, which accounts for $36 \%$ of U.S. Distllate Prices Increase with Crude Oll total energy consumption, presents a huge

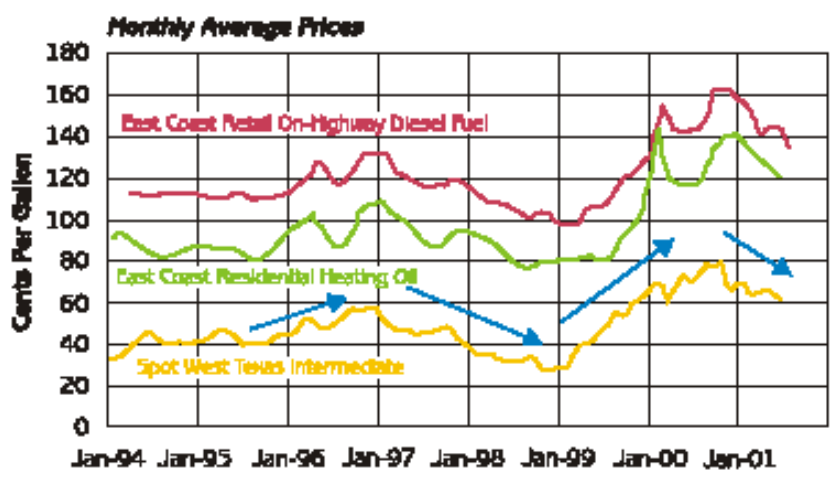

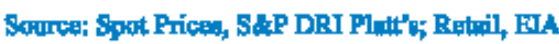
opportunity. Forty-six percent (46\%) of the U.S.'s electricity is consumed in the commercial energy space and water heating market. Currently, only $4 \%$ of commercial buildings nationwide use fuel oil for space and water heating, presenting a large market opportunity for this fuel.

\section{Environmental Pressures}

Air quality emission regulations for sulfur and NOx are becoming increasingly stringent. In past years, the oilheat industry has been able to respond to environmental requirements for limiting sulfur and NOx. With new, cleaner oil burning technologies, oilheat should be able to respond again.

Underground tank leaks can become very costly to homeowners and building managers. Fortunately, many states have pollution funds, which cover all, or part of pollution from tank leaks; private insurance is also available for around $\$ 100$ per tank.

\section{$\underline{\text { Regulatory and Institutional Constraints }}$}

Oilheat's image stands in the way of improvements in market share. This image, an often negative one, results from lack of education. Consumers switch from oilheat to natural gas, for no other reason than their perception that natural gas is less expensive and cleaner; in reality, converting to gas or electricity does not make economic or environmental sense. From an environmental perspective, it is better to conserve a BTU of oil by replacing old equipment or improving energy efficiency, than to replace the system with a BTU of gas.

Consumers need to be educated about oilheat's cost effectiveness and environmental friendliness. Residential and commercial/institutional builders need better information and technical assistance on oilheat system design and installation. A comprehensive marketing and education program will help shed oilheat's negative image and improve the environment for attracting industry workers. 
Federal and state transportation regulations specify the number of hours oilheat drivers may spend on the road. This has had a negative impact on the industry. Just recently, however, the U.S. Department of Transportation approved the Oilheat Delivery of Hours of Service Program. This program grants commercial motor vehicle drivers an exemption from hours-of-service restrictions when making winter home heating oil deliveries within a 100 air-mile radius of a central terminal or distribution point.

Fuel quality specifications will play a role in oilheat's future. Low sulfur fuel oil is beginning to gain favor as a home heating fuel. Current residential heating oil has an average sulfur value of $0.25 \%$. Studies have shown that sulfur emissions lead to fouling of heating oil equipment, lowering system efficiency and increasing the need for frequent equipment cleaning. Low sulfur $(0.05 \%)$ fuel oil is currently used in highway transportation; it can lower service costs and maintain oilheat system efficiency.

The heating industry is seasonal. Oilheat distributers respond to market demand by lowering their prices, affecting profitability. By contrast, the price of natural gas and electricity is allowed by state regulatory policies, to remain high during similar periods of low demand. This situation creates and unfair advantage for natural gas and electric utilities.

\section{Background and Structure of the Oilheat Vision and Roadmap}

The Oilheat Industry Roadmap process began with a Vision Workshop held at Brookhaven National Laboratory in August 2001. Oilheat dealers, researchers, equipment manufacturers, and other stakeholders considered the most critical market, regulatory, institutional, and technology issues affecting the future of oilheat and created a vision for 202 and beyond. The vision is shown below:

The oilheat industry will be a customer-driven supplier of premium indoor comfort. Oilheat will be a consumer fuel of choice -affordable, environmentally friendly, and offering total energy solutions for on-site space heating and cooling, hot water, and power. By capitalizing on its already strong infrastructure, the industry will provide worry-free, self-sufficient, virtually invisible energy systems to its customers. The oilheat industry will regain its commercial and institutional customers and expand its residential market. New niche markets will be developed, to capture a substantial portion of not only the heating market, but also the total energy market by the year 2020.

Following the Vision Workshop, a National Oilheat Industry Roadmap Workshop was held on November 13-14, 2001, at the University of Maryland, College Park, Maryland. This meeting involved many of the same stakeholders as the Vision Workshop, and others as well, who creatively looked at solutions to technical, institutional, and market barriers facing the industry. Participants refined the vision and strategic goals, identified barriers that threaten the growth of the industry, and developed actions to overcome the barriers. This roadmap, The Oilheat Industry Roadmap-Toward a Sustainable Energy Future, is a result of their deliberations. It consists of three main action areas: 


\section{- Improving fuel quality and performance}

- Enhancing equipment and service

- Expanding markets and applications

\section{Improving Fuel Quality and Performance}

The oilheat industry must strive to enhance oilheat fuel performance through improvements in fuel quality and storage systems. Problems associated with heating oil quality put the industry at a competitive disadvantage with other residential heating products, including natural gas and electric heat. Considering that fuel quality has decreased over the last 30 years, improving fuel quality must be a top priority for the industry.

The decline in fuel quality is attributed to refiners' preference for increasing the yield of a barrel of crude oil at the expense of fuel stability. Additionally, the quality and sulfur level of imported heating oil varies widely. The fuel's quality depends as well on the method by which it is stored, as most degradation occurs during storage. During storage, unstable fuels containing reactive fuel molecules combine to form larger macromolecules. In a process called "repolymerization," these macromolecules agglomerate into an undesired sludge. An additional problem affecting fuel quality is the presence of unwanted metallic elements.

A number of additives can be used to modify specific fuel properties and improve quality, enhance performance, and improve storage and handling characteristics. The most commonly used additives include flow improvers, detergents, antioxidants, corrosion inhibitors, metal deactivators, and biocides. Stabilizers are used to reduce "repolymerization" and detergents are used to reduce nozzle clogging, reduce soot build-up, and disperse sludge so that it can safely pass through the system. A metal deactivator can also be used to negate the degrading effects of copper particles. The additive's performance or fuel's response to a given additive must be measured to determine its dosage and effectiveness. Laboratory and field work analyzes how these various additive concentrations affect fuel quality and performance.

Improvements in fuel storage and quality have the potential to enhance oilheat's competitive edge in the marketplace. By utilizing existing research results and initiating new R\&D, barriers may be successfully addressed and the vision of the oilheat industry will be achieved.

The oilheat industry has identified eight priority actions that it believes will address the barriers to improving fuel quality, storage, and performance. With the exception of fuel system storage protocols and biodiesel fuel applications, successful completion of each action depends on the success of the others. All of them need to be addressed within five years and continued into the future. They are listed in chronological order; the first action needs to be completed before the second and so forth.

- Identify fuel quality research

- Develop additive and performance data

- Test and document ultra-low sulfur premium fuel data

- Develop fuel storage system protocols 
- Define a standard for premium high quality fuel

- Develop an educational program on the benefits of premium low-sulfur fuel

- Market premium oil to consumers

- Research applications of biofuels

\section{Enhancing Equipment and Sevice}

Oil-fired heating systems consist of several subsystems. The oil burner pump draws fuel from the tank, which is atomized and mixed with just the right amount of air for efficient combustion. An electric spark provides the ignition for the fuel/air mixture; and the flame produces heat in a combustion chamber, which is released to the heat exchanger. Air is thus heated in the furnace or water in the boiler. The heated air or hot water is routed through ducts or pipes to radiators or hot water baseboard units located throughout the building. By-products of this combustion process, which primarily include water vapor, carbon dioxide and minor amounts of sulfur dioxide, nitrogen

Oil Heating System

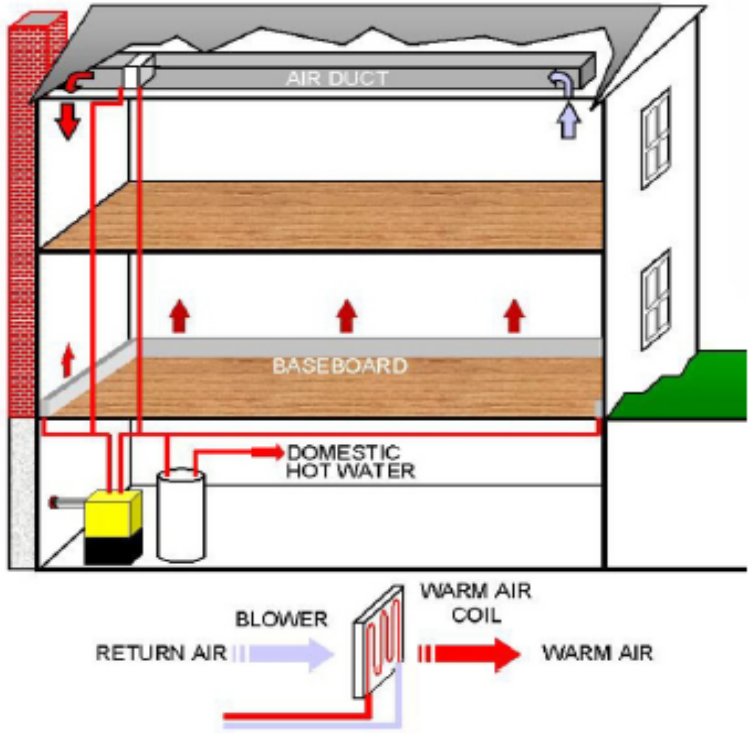
oxides, and particulate matter, are exhausted to the outside ambient environment through a flue pipe connected from the heat exchanger to a chimney or a direct ventilation system.

These oilheat subsystems consist of many parts, which work in a harmonious fashion to produce heat efficiently. When there is a malfunction in the oilheat system, a highly trained technician has to be able to diagnose and fix the problem in a timely manner. Enhancements in oilheat equipment and service will reduce malfunctions, lower total installed system costs, maintain high efficiencies, and lower environmental emissions, ultimately leading to an expansion of markets and applications for oilheat.

The oilheat industry has identified six key actions to enhance equipment and service and help achieve the vision for the oilheat industry. They are:

- Institute low sulfur fuel as standard

- Develop a research and development plan for the oilheat industry

- Lower the total installed costs of the oilheat system

- Build an RD\&D program for low-NOx systems

- Develop self-diagnostic and self-adjusting control technologies

- Research novel combustion techniques 


\section{Expanding Markets and Applications}

The oilheat market has remained flat, or has declined, during the last twenty-five years. As a result, the industry is developing new strategies to maintain and grow its market share while utilizing oil in innovative, potentially revolutionary ways. Market share improvements -- retaining existing customers and reaching out to new ones, enhancing marketing and advertising, and changing the public's perception of oilheat - must be on the industry's agenda if its future is to grow brighter. New and expanded applications for oil are being investigated as well, including use of oil-fired energy systems for integrated buildings, cooling, heating, and power; on-site electric generation;

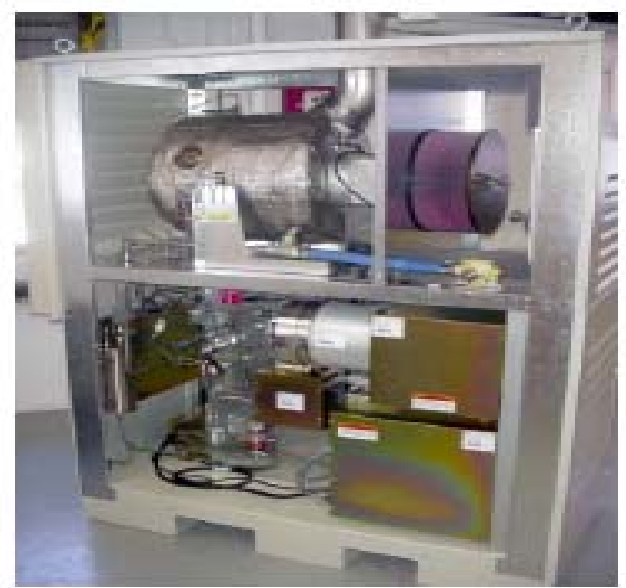

Diesel Micro Turbine Electric Power Generator domestic hot water and air conditioning; desiccant cooling systems; photovoltaic systems; and fuel cells. Among the industry's goals for the long term future are:

- Changing the public's perception to one of oilheat as a clean, costeffective, and versatile fuel

- Accelerating electric-to-oil conversions in existing buildings, and improving the market share for oilheat systems in new construction by $5-10 \%$ by 2020

- Expanding energy efficiency and distributed energy services to oilheat customers, including on-site electric generation, oil-fired, energy efficient space and water heating and cooling, and oil-fired integrated buildings, cooling, heating, and power (BCHP) systems

The oilheat industry has identified six priority actions to address the barriers listed above and to achieve the vision that all industry stakeholders support for the future:

- Change consumer perceptions about oilheat

- Improve builder education and incentive programs

- Grow an educated oilheat workforce

- Research potential growth markets

- Increase electric to oil conversions

- Integrate oilheat with new, advance building technologies, equipment, and systems 


\section{Acknowledgements}

- Arlex Oil

- Brookhaven National Laboratory

- CAMNET

- Carlin Combustion

- Champion Energy

- Energetics, Inc.

- Energy Kinetics

- Energy Research Center

- ET Lawson

- Exergy Partners

- Fuel Advantage Marketing

- Hago Manufacturing

- Hughes Oil

- National Association of Oilheat Service Managers

- National Oilheat Research Alliance

- New England Fuel Institute

- New York State Energy Research and Development Authority

- Oilheat Manufacturing Association

- Oilheating Journal

- Petro

- Petroleum Marketing Association of America

- RW Beckett

- Santa Fuels

- Suntec

- The SICO Company

- Thermo Products

- Thermo-Dynamics

- U.S. Department of Energy

- VR Boltz

- Weyant Oil Services 
Paper No. 02-05

IES Heating Oil Fueled Microturbine Power Technology

Roger J. McDonald

Brookhaven National Laboratory

Building 526

12 North Six Street

Upton, NY 11973

Phone: 631-344-4197

Fax: 631-344-2359

E-mail: mcdonald@bnl.gov

Internet: www.bnl.gov 


\title{
IES Heating Oil Fueled Microturbine Power Technology
}

\author{
Roger J. McDonald, Brookhaven National Laboratory (BNL)
}

\section{Introduction}

Integrated Energy Systems (IES) combine onsite power generation or distributed generation technology with thermally activated technologies to provide cooling, heating, and other process functions using the thermal energy normally wasted in the production and transportation of electricity. The IES program provides technology solutions to meet the objectives of doubling the overall efficiency, providing energy choices, reducing environmental emissions, conserving fuel, increasing energy security, and optimizing energy delivery. The United States Department of Energy, Office of Distributed Energy and Electricity Reliability (DOE/DEER) has sponsored BNL to conduct an Integrated Energy Systems project. This effort involves microturbine based technology used for distributed power generation as well as integrated applications including heating, ventilation and air-conditioning (HVAC) functions in the future. The future of this technology can provide an opportunity for the oilheat industry to open new markets for their product and expand the potential of IES system benefits in a synergistic effort.

The oil fueled microturbine power generator installed at BNL during 2002 and is supplied with ASTM No. 2 heating oil. The turbine unit is capable of producing up to 29 kilowatts of electricity, which is utilized by the local power grid. Initial results as presented provide for an evaluation of performance characteristics including efficiency under various operating conditions, as well as detailed environmental emissions.

The unit can also be connected to a heat recovery system that was designed and built to extract waste exhaust heat from the turbine exhaust. In the future, the system will be tested as a cogenerator supplying both electricity and heat to the building over the winter periods. The heat exchanger will supply a portion of the heat to the building where the unit is installed. This building houses among other groups, the BNL Oilheat Research Program and the Oilheat Research Laboratory. Future project plans may also include performance characterization using renewable bio-fuels such as biodiesel and other similar bio-sourced liquid fuels. Recent discussions with an international research organization may also provide an opportunity to obtain an absorption cooling unit to be coupled to the microturbine providing cooling in the summer time.

\section{Description of the Microturbine Technology}

Although many oilheat marketers may supply diesel fuel to customers with diesel-fired stationary reciprocating engine generators, most may not be as

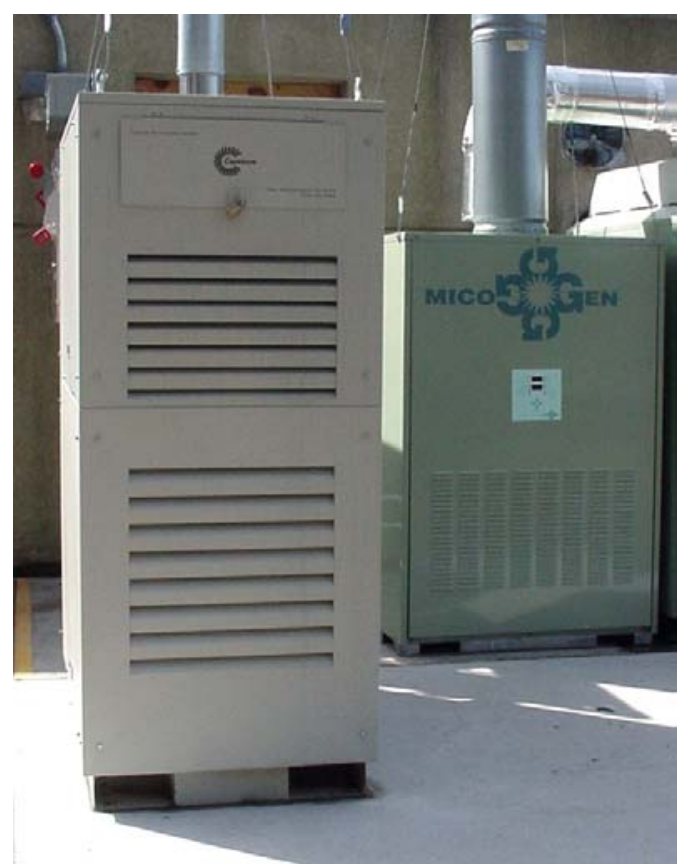

Figure 1 Heating oil fueled $29 \mathrm{~kW}$ microturbine installed at the BNL Oilheat Research Laboratory 
familiar with microturbine driven systems. Miroturbine systems are a very recent product innovation. They were first marketed in 1998 following ten years of research and product development.

A turbine is a heat engine and uses the combustion of fuel and air to produce output power. The turbine combustion engine has three basic components: an air compressor, a combustor where fuel is injected and a turbine where the products of combustion expand in a turbine to produce power. To enhance the efficiency a heat recuperator is often used in the design to extract waste heat from the exhaust used to preheat combustion air before fuel injection. In this application, the power output from the turbine is designed to maximize shaft power connected to a generator while trying to minimize undesired combustion exhaust emissions.

The system installed at BNL incorporates a compressor, recuperator, combustor, turbine and permanent magnet generator. The rotating components are mounted on a single shaft that rotates up to 96,000 RPM (full load) and is supported by air bearings. The generator is cooled by intake airflow, eliminating the need for liquid cooling.

The microturbine is a compact power generator providing electrical power up to $29 \mathrm{~kW}$. The unit can be configured in grid-connect mode (as installed at BNL) or in a stand-alone mode as a power backup source. It supplies 400-480 VAC, 50/60 HZ

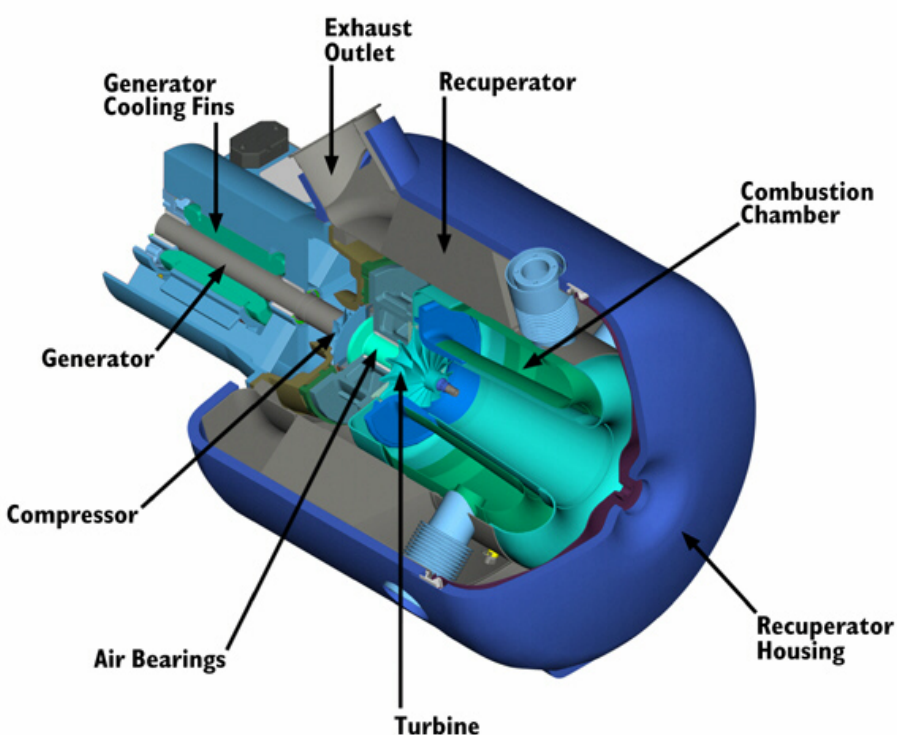

Figure 2 Cut-a-way drawing of microturbine three-phase power. The unit tested includes a digital based power controller with patented software. Solid state power electronics allow grid-connected operation. The unit is an air-cooled designed with patented air bearing on the turbine and includes an outdoor enclosure. The unit is approximately 80 inches in height as has a foot print of 30 inches in width and 60 inches in depth and weighs approximately 900 pounds. The unit does not require any liquid lubricants or cooling liquids.

\section{Test Plan Summary}

The installation of the oil microturbine was finished and all operational readiness and safety reviews were completed by May 2002. Initial test plans were focused on emission characterization and determination of the operating efficiency of the unit. This included determination of nitrogen oxides (NOx), carbon monoxide and oxygen concentration coupled with measurements of fuel consumption and electric power output under various load conditions, 
from $10 \mathrm{~kW}$ up to the maximum output. The unit is nominally rated at $29 \mathrm{~kW}$ but actual output and efficiency are dependant on ambient conditions particularly temperature, as with any combustion turbine. The turbine cycle being dependent on the integral air compressor component is sensitive to changes in air density and as such temperature is a significant factor.

In the future the unit can be combined with other components of the BNL Integrated Energy System including the heat exchanger (already in place) which will recover waste heat from the exhaust and supplies this heat to the building during the heating season. The oil-fueled microturbine is part of a larger micro-power-grid being assembled at BNL. Plans also call for future expansion into cooling technologies using absorption chillers and fuel cell technologies including the use of fuel cells powered by oil.

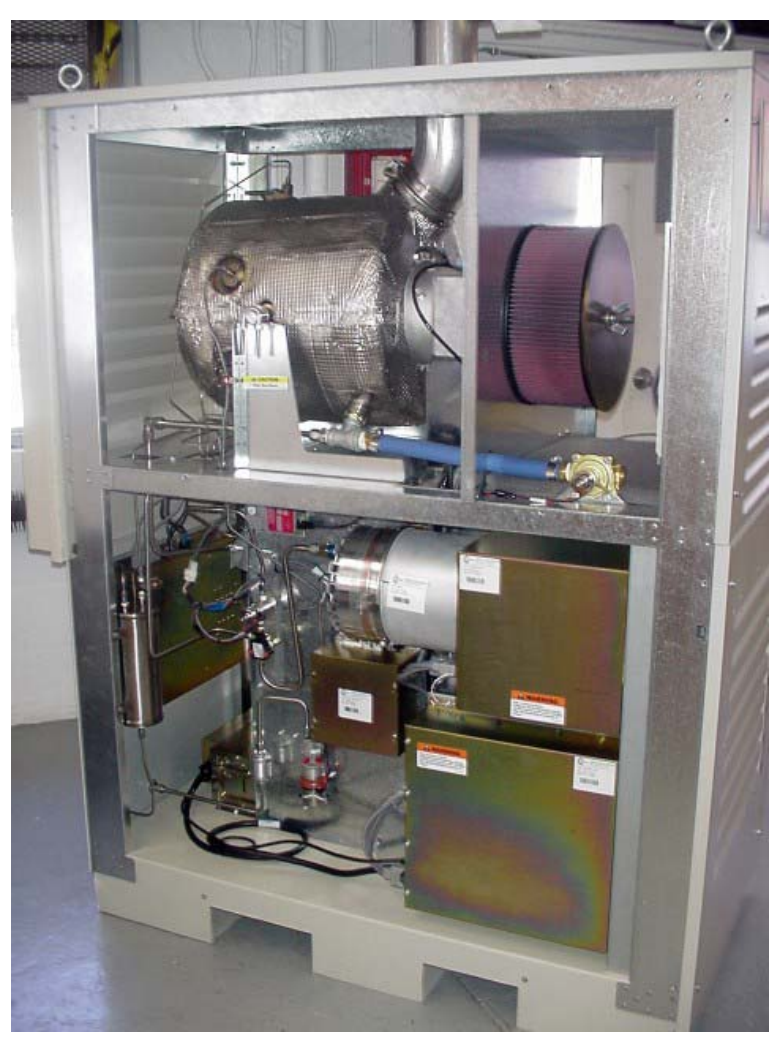

Figure 3 Interior view of microturbine

\section{Test Apparatus}

Efficiency: The fuel consumption was measured using a positive displacement flow meter (Ista Model VZO-4) with an accuracy of $+/-1 \%$ and a resolution of $1 / 100$ gallon. A contracted testing laboratory following ASTM test standards determined the density of the fuel and heating value. The electric power output was monitored by using the manufacturers on board sensors using a remote monitoring software system supplied. This software package can monitor over sixty operational data points and store them in a file in a spreadsheet format.

Emissions: Emission data was obtained using BNL's Oilheat Laboratory analyzers. Nitrogen oxide was measured with a Beckman Model 955 chemiluminesent analyzer. Carbon monoxide and oxygen levels were measured using a Testo 350 portable combustion analyzer, which uses electrochemical cells for oxygen and carbon monoxide detection.

\section{Results}

Efficiency:

The efficiency of the microturbine and the electric power output (load) both as a function of the firing rate are shown in Figure 4. The tests were run at the maximum output level, $25 \mathrm{~kW}, 20$ $\mathrm{kW}, 15 \mathrm{~kW}$ and $10 \mathrm{~kW}$ power level demands. The manufacturer specifications indicate an efficiency of $24.4 \%(+/-2 \%)$ at air temperatures below $59 \mathrm{~F}$ and using the higher heating value of the fuel. The ambient air temperatures on the day of the tests were in the range of 69 to $71 \mathrm{~F}$ with a pressure of 30.32 inches of $\mathrm{Hg}$. The efficiency at this temperature range was expected to 
be somewhat lower, near $22.5 \%$ based on the manufacturer's data. Indeed BNL measured an efficiency of $22.2 \%$. These numbers are in excellent agreement and the difference is well within the measurement error range. During early testing of the unit prior to the detailed measurements reported in this paper, the unit's efficiency was measured at $23 \%$. This was during March when the temperatures were lower. During mid-winter periods an efficiency level of $24 \%$ would seem reasonable based on this data. Next winter this will be determined with more precision.

\section{Power Ouput and Efficiency versus Input Rate}

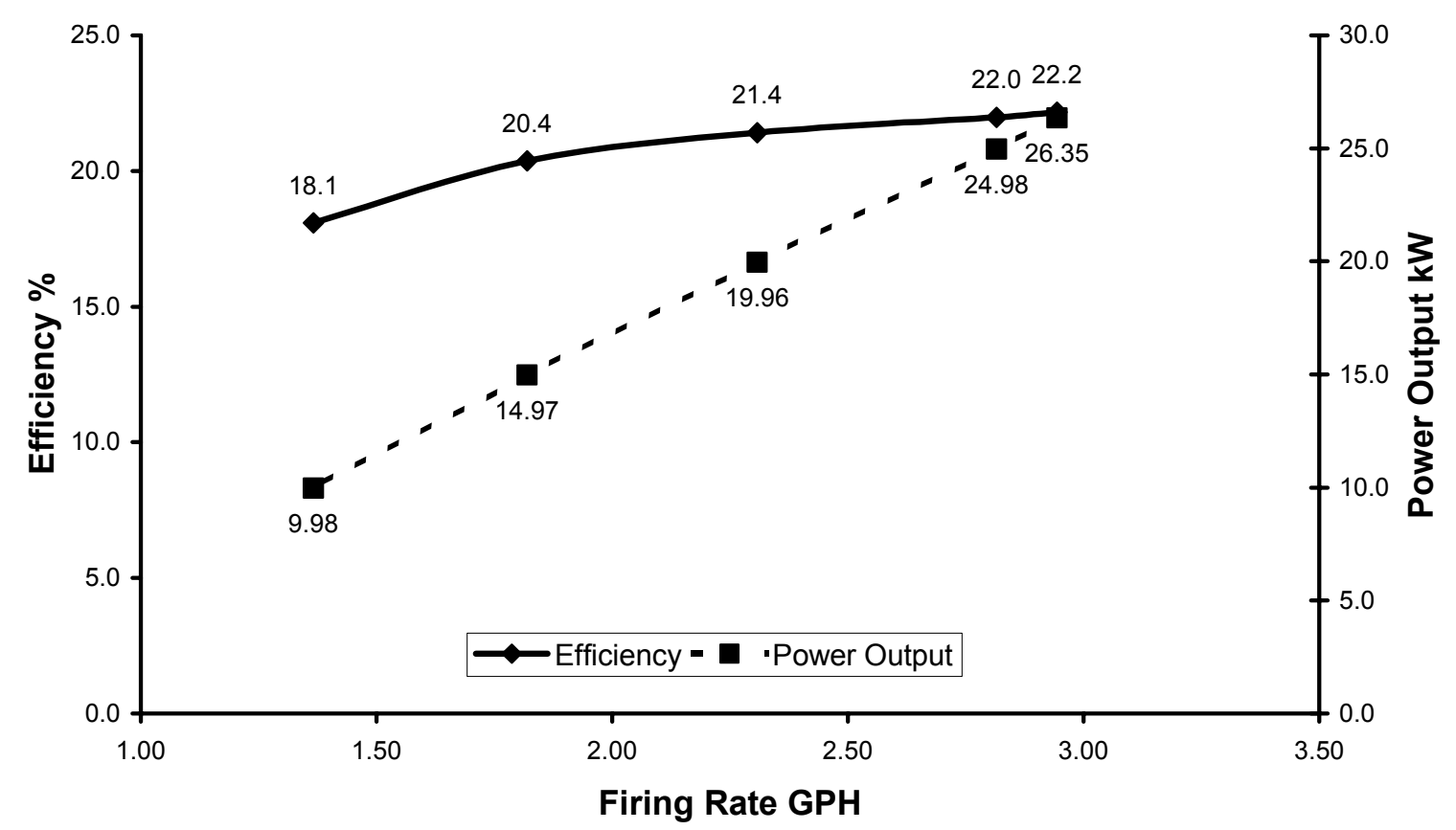

Figure 4 Efficiency and Power Output Characteristics

Emissions:

The environmental emissions most relevant concerning combustion turbines are nitrogen oxides (NOx) and carbon monoxide (CO). NOx is a precursor to the formation of ozone in the atmosphere, which causes smog. $\mathrm{CO}$ is a poisonous gas formed when carbon is not fully burned. The US Environmental Agency is concerned with ambient air limits of both. The manufacturer of the microturbine tested at BNL designed the unit to limit the emissions of both $\mathrm{CO}$ and NOx.

According to the manufacturer of the microturbine tested, it uses a lean-premix combustion system to achieve low emissions at the full power range. Lean-premix operation requires operating at a high air to fuel ratio within the primary combustion zone. The large amount of air is thoroughly mixed with the fuel before combustion. This premixing of the air and fuel enables clean combustion to occur at a relatively low temperature. Injectors control the air to fuel ratio and the air-fuel mixture in the primary zone to ensure that the optimal flame temperature is achieved for NOx minimization. 
The higher air to fuel ratio results in a lower flame temperature, which leads to lower NOx levels. In order to achieve low levels of $\mathrm{CO}$ with low NOx levels, the air and fuel mixture is retained in the combustion chamber for a relatively long time period. This allows for more complete combustion of the $\mathrm{CO}$. The unit has a large primary zone volume within its combustor chamber, which allows the air and fuel to remain in the combustion zone for a relatively long time period according to the manufacturer.

Figure 5 presents the NOx data obtained by BNL during its tests of the microturbine. Data is plotted as measured and corrected to both $3 \%$ and $15 \%$ oxygen levels. The data at the $3 \%$ oxygen level correction is included for comparison to results obtained when testing boilers or furnaces where it (3\%) is the basis for comparison. Likewise for turbines $15 \%$ is the normal basis for comparison. The oxygen measurements ranged from $18.1 \%$ at the highest firing rate to $18.7 \%$ at the lowest fuel input rate.

\section{Nitrogen Oxides (NOX) Emissions}

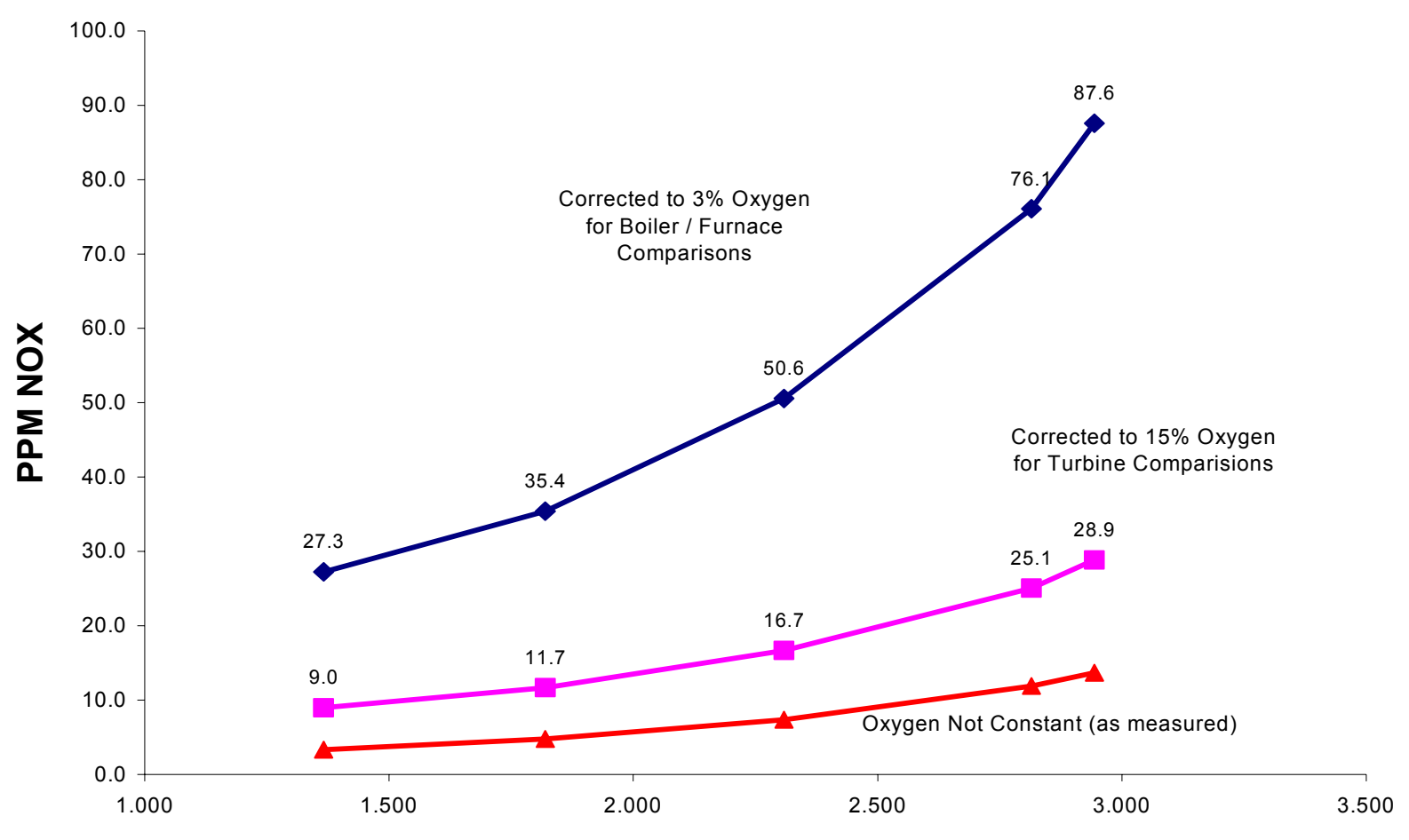

Firing Rate GPH

Figure 5 Nitrogen Oxide Emission Data

It is important to keep in mind that the determination of NOx emission levels is quite challenging at these levels, very dilute (high oxygen content) and very low as measured actual values, in the range of 3-14 ppm. Very slight shifts in the values can shift the corrected values significantly up or down. They are however very interesting in that the maximum value was $88 \mathrm{ppm}$ (at $3 \%$ oxygen) or $29 \mathrm{ppm}$ (at 15\% oxygen) and compare favorably with modern residential oil-fired 
heating equipment. When compared to stationary reciprocating engine generators they are dramatically lower. The shape of the curve indicates a strong dependence on input rate which can be anticipated as thermal NOx formation is most likely the predominant contributor to the total NOx emission level. At lower fuel input rates the combustion intensity would be significantly reduced producing lower temperatures on average.

The carbon monoxide data is presented in a similar manor in Figure 6.

\section{Carbon Monoxide (CO) Emissions}

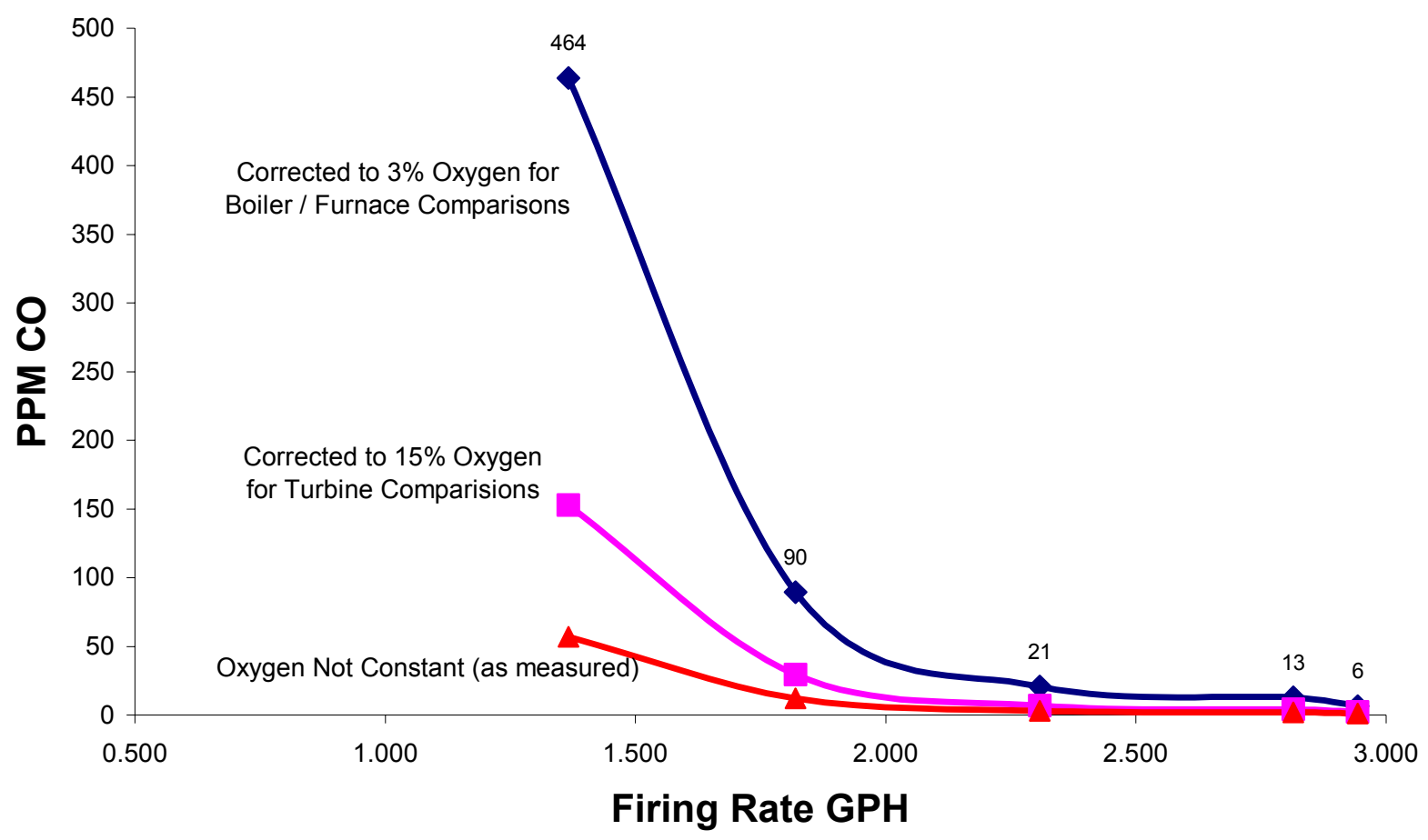

Figure 6 Carbon Monoxide Emission Data

Again, with the exception of the lowest firing rate $(10 \mathrm{~kW}$ output) the $\mathrm{CO}$ levels are quite low. This holds true even when corrected to $15 \%$ oxygen levels. At the $3 \%$ oxygen level a corrected measurement of $90 \mathrm{ppm}$ at the $15 \mathrm{~kW}$ level starts to indicate less then optimum performance when compared to a residential oil heating system. Again, it is important to remember that the actual emission measurements are all below $60 \mathrm{ppm} \mathrm{CO}$ even at the $10 \mathrm{~kW}$ output level.

\section{Conclusions and Future Plans}

Although there is more testing planned for the microturbine in the future, to date the results are significant. At maximum electric power output, the turbine has an efficiency of $22.2 \%$ based on the higher heating value. The emissions are quite low for a combustion system as indicated in the prior discussion. In order to illustrate this point Figure 7 indicates how the microturbine NOx 
emission data compare with other stationary systems capable of generating power in an Integrated Energy System. The values are those used by the US Environmental Protection Agency in AP-42 as compared to the microturbine tested. Carbon monoxide emission data also indicate low levels except at the lowest power output levels. Even at this load condition, at the high excess air levels of operation in the turbine, the result is a low concentration in volumetric terms.

\section{Emission Factors}

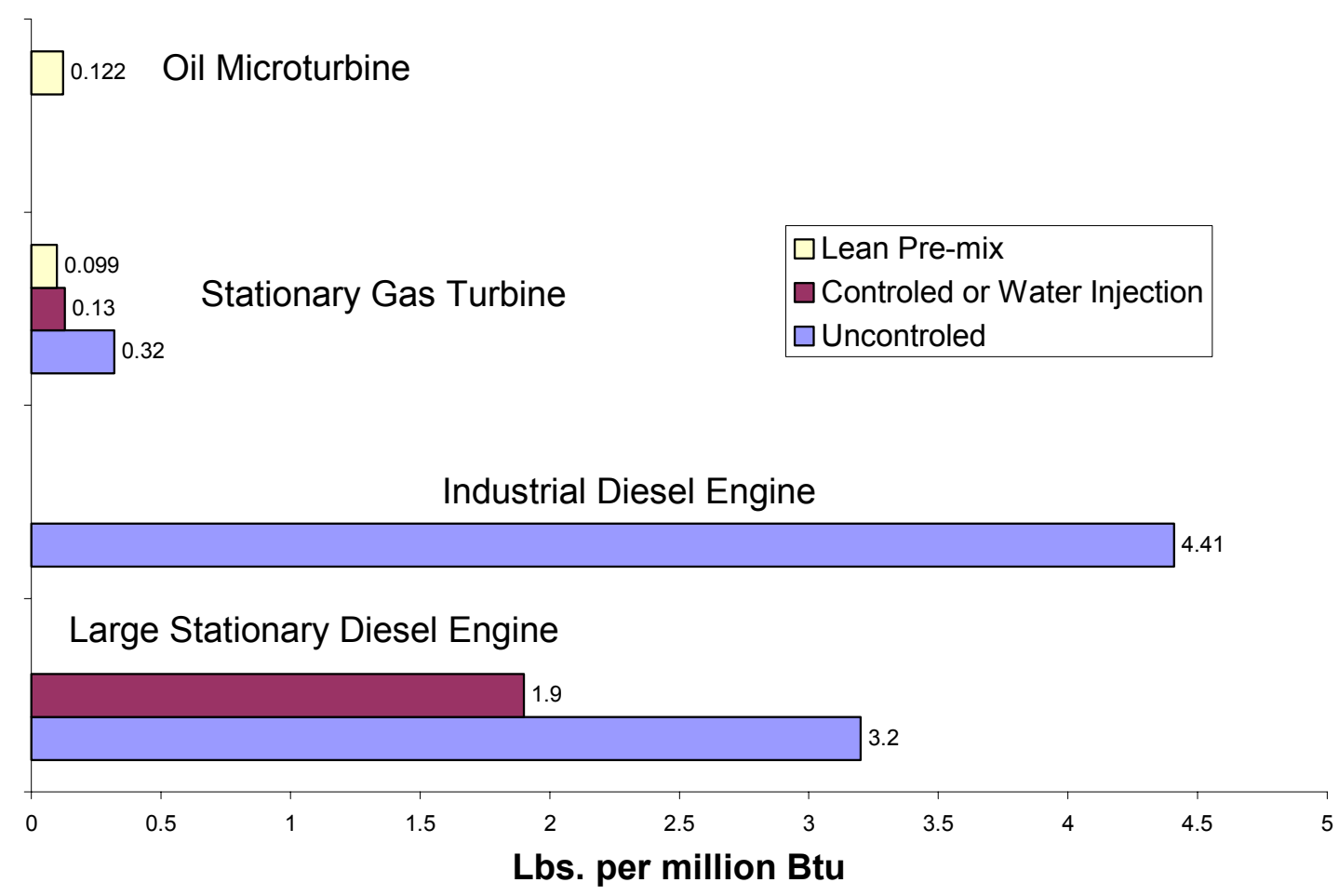

Figure 7 Diesel Engine and Turbine Emission Factors

In the future, the microturbine will be evaluated under various seasons including wintertime operation. The system will be evaluated with regard to it use as part of an actual Integrated Energy System where waste heat will be used to power heating or cooling system components designed for use with the power generator. This year it was already too late to recover waste heat. The heating season ended before the completion of the site installation and start of the microturbine tests.

When looking at the potential of this system in an IES mode it is important to consider the nature of the combustion products coupled with the design of the planned heat exchanger. The device that would make use of the normally wasted heat must be design appropriately. When fired with a normal sulfur content level heating oil with up to $0.5 \%$ by weight, it is essential to consider the potential for corrosion and fouling of a heat recovery system. If a low sulfur content heating oil with a maximum sulfur content of $0.05 \%$ by weight is selected the potential for corrosion with be 
dramatically reduced. If the full potential in the waste heat is to be extracted the system must be designed to withstand the condensation process, which is the worst case condition. Table 1 lists the significant results of the study in tabular format. Under the maximum electric output, the heat lost up the stack is approximately 280,000 Btu per hour. The exhaust is very dilute, an excess air level of almost $600 \%$. The stack temperature was $560 \mathrm{~F}$ gross. Allowing for conventional materials (non-condensing), a realistic figure for a combined IES efficiency is estimated at about $70 \%$.

Table 1 Summary of ASTM No.2 Heating Oil Fueled 29 kW Microturbine Results

\begin{tabular}{|c|c|c|c|c|c|c|c|c|c|c|c|c|}
\hline GPH & $\begin{array}{c}\text { kW } \\
\text { Output }\end{array}$ & $\begin{array}{c}\text { Eff. } \\
\%\end{array}$ & $\begin{array}{c}\text { Stack } \\
\text { Temp F }\end{array}$ & $\begin{array}{c}\text { O2 } \\
\%\end{array}$ & $\begin{array}{c}\text { Excess } \\
\text { Air \% }\end{array}$ & $\begin{array}{c}\text { Btu Loss } \\
\text { Stack }\end{array}$ & $\begin{array}{c}\text { NOx } \\
\text { @Ox } \\
@ 3 \%\end{array}$ & $\begin{array}{c}\text { NOx } \\
@ ~ 15 \%\end{array}$ & $\begin{array}{c}\text { CO } \\
\text { @ 3\% }\end{array}$ & $\begin{array}{c}\text { CO } \\
@ ~ 15 \%\end{array}$ \\
\hline 2.94 & 26.6 & 22.2 & 561 & 18.1 & 584 & 280066 & 13.7 & 87.6 & 28.9 & 1 & 6 & 2 \\
\hline 2.82 & 25.0 & 22.0 & 555 & 18.1 & 584 & 264003 & 11.9 & 76.1 & 25.1 & 2 & 13 & 4 \\
\hline 2.31 & 20.0 & 21.4 & 522 & 18.3 & 634 & 215818 & 7.4 & 50.6 & 16.7 & 3 & 21 & 7 \\
\hline 1.82 & 15.0 & 20.4 & 487 & 18.5 & 693 & 169181 & 4.8 & 35.4 & 11.7 & 12 & 90 & 30 \\
\hline 1.37 & 10.0 & 18.1 & 464 & 18.7 & 761 & 129616 & 3.4 & 27.3 & 9.0 & 57 & 464 & 153 \\
\hline
\end{tabular}

GPH - gallons per hour input, Eff. - efficiency based on higher heating value, NOx and CO presented as measured and corrected for $3 \%$ and $15 \%$ oxygen levels for comparisons.

The microturbine tested was equipped with a recuperator used for internal heat recovery of the heat energy rejected by the turbine. This heat is recycled to increase the turbine efficiency. The turbine without the recuperator would have an efficiency of only about $15 \%$. However, the unit as tested (with a recuperator) may not be the optimum for an IES system. A computer model found in the literature (based on a similar microturbine) indicates that a unit without a recuperator may be coupled with a heat recover unit and achieve an IES efficiency of up to about $75 \%$. However, the electrical output would be only represent about $15 \%$ of the input fuel energy.

In the future BNL is also hopeful that an appropriate thermal absorption cooling technology can be identified for IES testing as well as evaluating the use of biodiesel or alternate biofuel blends as a fuel source.

Acknowledgements:

The author would like to acknowledge the contributions of Yusuf Celebi (BNL Engineer) who provided his excellent talents in helping to conduct the laboratory testing of the microturbine and C.R. Krishna, Ph.D. (BNL Science Staff) who provided valuable consulting expertise on turbine design and operation. The author would also like to thank DOE/DEER for supporting this work, in particular Ronald Fiskum, DOE Program Manager. This work was conducted by BNL under DOE contract DE-AC02-98CH10866 with Brookhaven Science Associates. 


\section{Paper No. 02-06 \\ Update on Use of Biodiesel Blends in Boilers}

C.R. Krishna, T.A. Butcher, R.J. McDonald, Y. Celebi and G. Wei Brookhaven National Laboratory \& Ralph R. Mills, Abbott \& Mills Inc.

Building 526

12 North Six Street

Upton, NY 11973

Phone: 631-344-4025

Fax: 631-344-2359

E-mail: krishna@bnl.gov

Internet: www.bnl.gov 


\title{
Update on Use of Biodiesel Blends in Boilers
}

\author{
C.R. Krishna, T.A. Butcher, R.J. McDonald, Y. Celebi and G. Wei \\ Brookhaven National Laboratory \\ Ralph R. Mills \\ Abbott \& Mills Inc.
}

\subsection{Introduction}

Biodiesel is a 'diesel-like' fuel that is derived from processing vegetable oils from various sources, such as soy oil, rapeseed or canola oil, and also waste vegetable oils resulting from cooking use. The American Society for Testing and Materials (ASTM) has recently published a standard for biodiesel, D 6751-02. In view of its similarity to diesel fuel, it has been tested fairly extensively in diesel engines. It has not been as widely tested for boiler applications and in residential heating applications.

If it could be demonstrated that blends of biodiesel and heating oil can be used with few or no modifications to the equipment or operating practices in space heating, substantial benefits may be realizable. A fraction of the national fuel needs could be met with domestic and potentially locally produced agricultural based fuels, which are renewable and environmentally beneficial, being sulfur-free, biodegradable, and nontoxic. It could also contribute to fuel source diversity for space heating, reducing the vulnerability to petroleum market disruptions, and providing a cushion for the effects of future sudden price spikes. This paper will describe some of the results obtained from testing in the laboratory and in the field that could help in meeting this goal.

\subsection{Biodiesel Fuel Blends}

\subsection{Composition, Heating Value and Biodiesel Blend Terminology}

Biodiesel is a name applied to fuels manufactured by the esterification of renewable oils, fats and fatty acids. The fatty acids may be derived from vegetable oils such as soybean or rapeseed (canola), rendered tallow, or waste materials such as cooking and trap greases [1]. The resulting product has $10-12 \%$ oxygen by weight and little or no sulfur and has been shown to reduce the particulate emission in diesel engine use. Chemically, it is essentially non-aromatic and has a higher cetane number than normal diesel fuel. It has a heating value of about 123,000 BTU per gallon compared to about 140,000 BTU per gallon of \#2 fuel oil. It has a slightly higher density. Biodiesel is completely miscible with home heating oil and so blends can be easily generated if mixed well so that the differences in density do not lead to stratification. In passing, a matter of common terminology should be noted. The blends are made in volumetric percentages and designated as $\mathrm{B} X$ where $X$ is the percentage of biodiesel in that blend of biodiesel in petroleum diesel. For example, B10 has $10 \%$ biodiesel and B100 is neat biodiesel. In the work reported here, the blends were made with home heating oil rather than diesel. 


\subsection{Fuel Blend Properties}

As part of the research done at Brookhaven National Laboratory, some of the properties of the blends relevant to burning were measured by a testing laboratory. They are given below as figures 1-3.

Flash Point of Heating Oil Blends

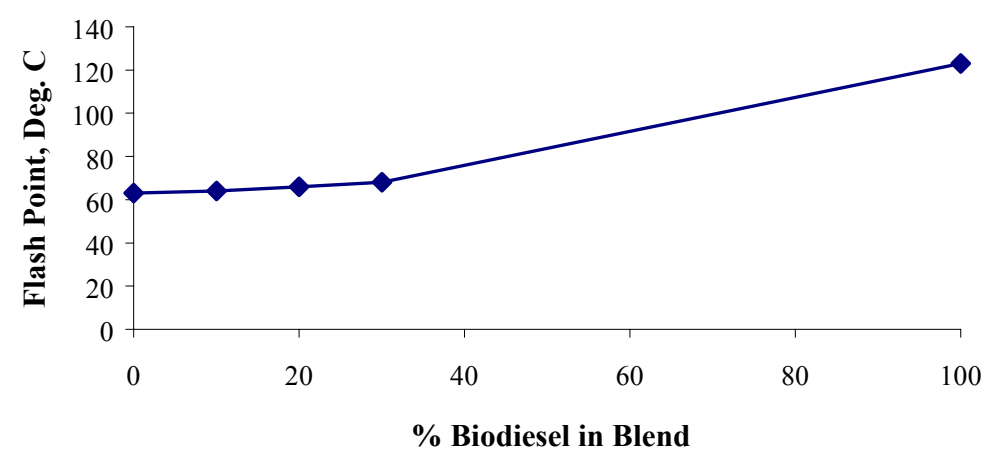

Figure 1. Flash Points of Blends

Viscosity of Biodiesel Blends in Fuel oil

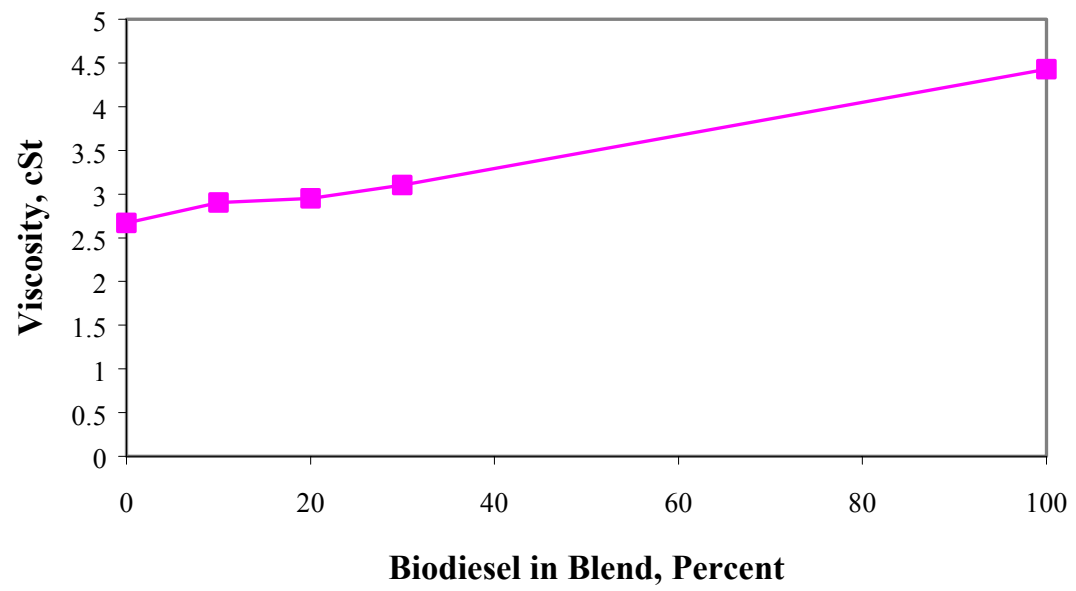

Figure 2. Viscosity of Blends 
Pour Point of Heating Oil Blends

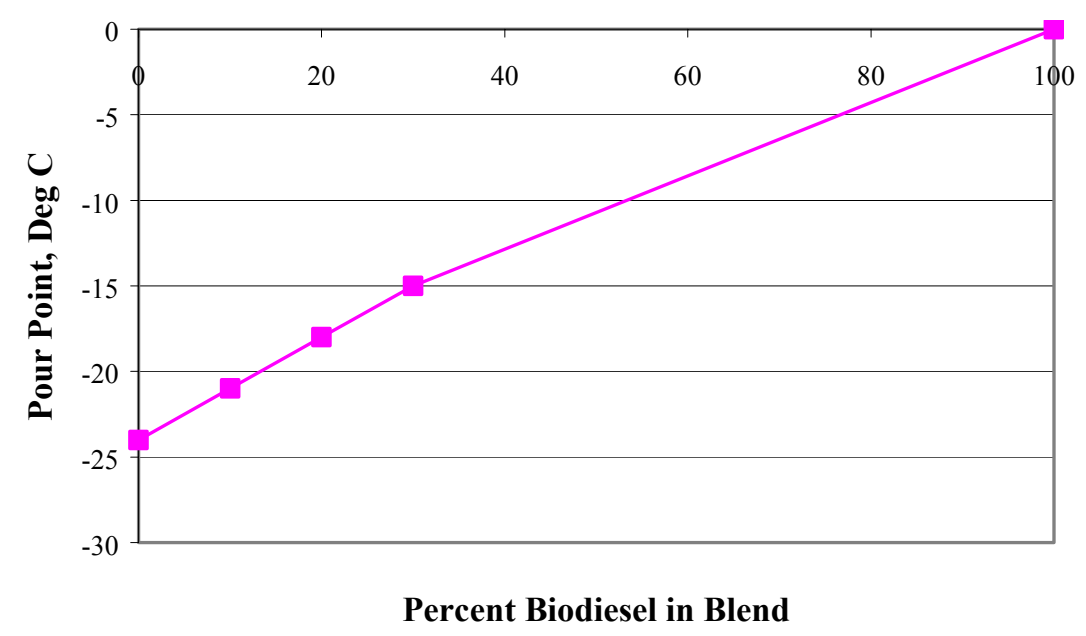

Figure 3. Pour Point of Blends.

Figure 1 shows that the flash point does not change significantly up to about $30 \%$ biodiesel in the blend, which could indicate that ignition in a boiler will not be much different with blends at least up to that value. The viscosity range shown in figure 2 indicates that even the neat biodiesel is within the range allowed by the ASTM \# 2 oil specifications. The pour point variation shown in figure 3 identifies one of the potential areas of concern in use of the blends in normal usage in home heating. There seems to be a significant increase in the pour point (and by inference, in the cloud point) with the blends and could pose problems of storage in non-heated or out-door locations in the winter months. This will be addressed to some extent in the report on the field tests below.

\subsection{Laboratory Testing of Biodiesel Blends}

\subsection{Laboratory Tests in a Residential Boiler}

The test facilities in the Oilheat Research Laboratory were used for these tests. The blends were fired in a three section, cast iron, wet base boiler. The hot water was cooled by circulation through a plate heat exchanger, which in turn was cooled by building water. A modern retention head type burner with a pressure nozzle rated at 0.6 gallons per hour and operating at a pump pressure of $140 \mathrm{psi}$ was used in the tests. These conditions were maintained for all the blends. The Burner operating conditions were set using the value of oxygen in the stack and of Bacharach smoke number with the No. 2 oil and were left unaltered for subsequent runs with the different blends. No changes were made to the nozzle, the ignitor, the cad cell and the control. 
Constant sampling flue gas emission analyzers were used to measure the concentration of oxygen (paramagnetic measurement), nitrogen oxides (chemi-luminescent measurement) and carbon monoxide (infrared measurement) in the exhaust stack. A special sampling line built to meet the requirements of the analyzers is used to draw the sample from the stack. Smoke was measured using the ASTM \# D2156-80 method and a manually operated piston type sample pump. Figure 4 is a photograph of the test set up.

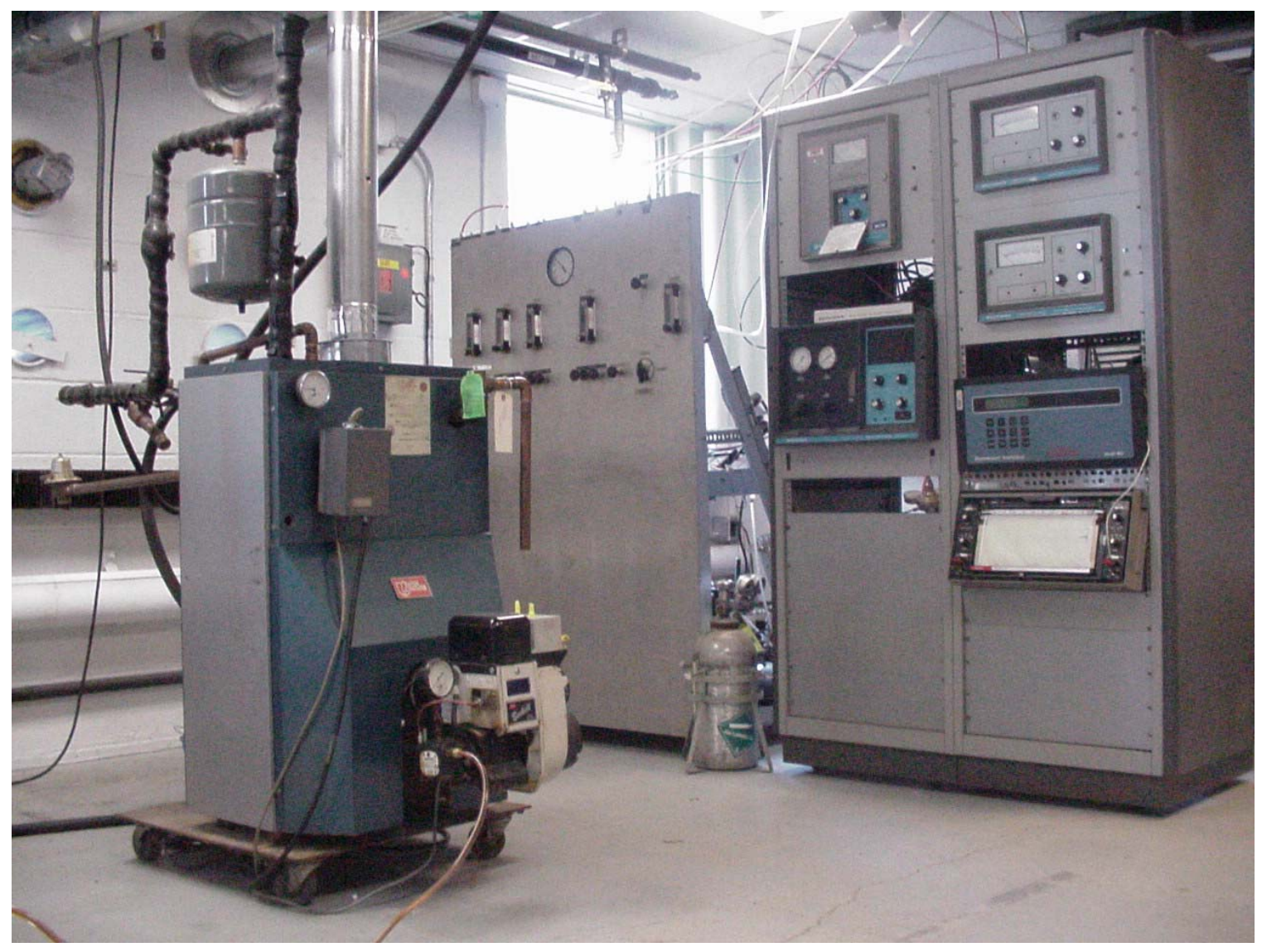

Figure 4. Residential Boiler Test Set up

The steady state tests were conducted by letting the boiler warm up to the normal operating temperature of about $140^{\circ}-150^{\circ} \mathrm{F}$. The Smoke number, NOx and the $\mathrm{CO}$ were measured at different excess air levels by changing the settings of the air damper on the burner and reflected by changes in the measured oxygen concentration in the stack.

\subsection{Results from Residential Boiler Tests}

The comparative performances will be reported as a function of stack oxygen, which corresponds to excess air. Figure 5 suggests that the B20 emits slightly lower Carbon Monoxide than the base $\# 2$ fuel. Broadly speaking, the addition of the biodiesel seems to reduce the emission of carbon monoxide, probably as one would expect. 


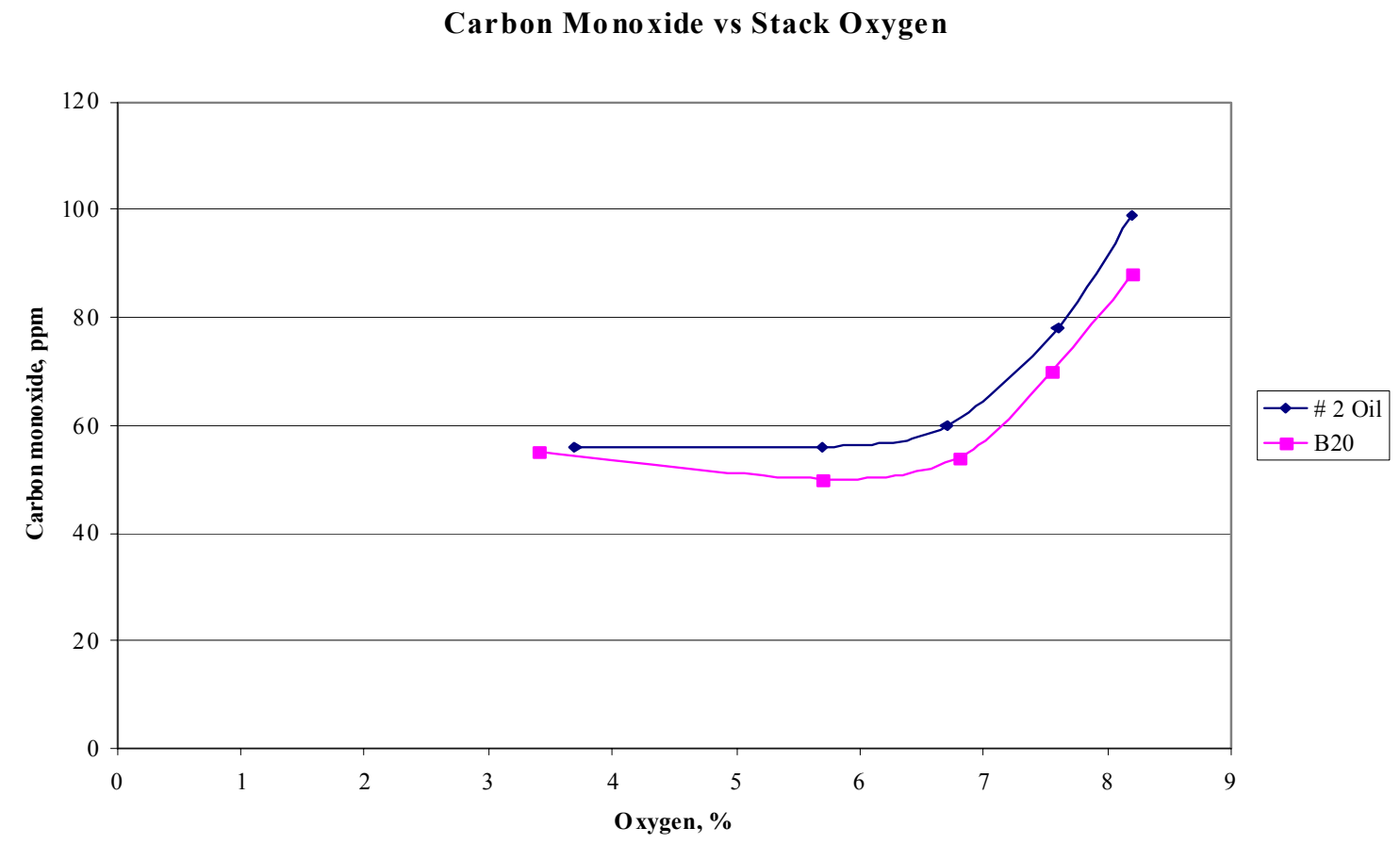

Figure 5. Carbon Monoxide emissions in blend tests

Figure 6 below is a composite of the NOx emission from all the blends and fuel oil. It is clearly evident that the NOx levels are lower especially at higher amounts of biodiesel in the blends. This was somewhat unexpected, as the diesel engine data indicate similar or slightly higher NOx with biodiesel blends than with petroleum diesel. Of course, the combustion situations are vastly different. This reduction in NOx in boilers could be an advantage in the use of biodiesel (and blends) in such applications. While one could generally say this might be due to lower flame temperatures, a more detailed study would be needed to establish the reasons for it, especially in view of the apparent contrary results in engines. The presence of oxygenated compounds in the fuel, which amount to about $10 \%$ by weight of oxygen, as well as possibly lower nitrogen than home heating oil, could be partly responsible for this reduction in NOx. 


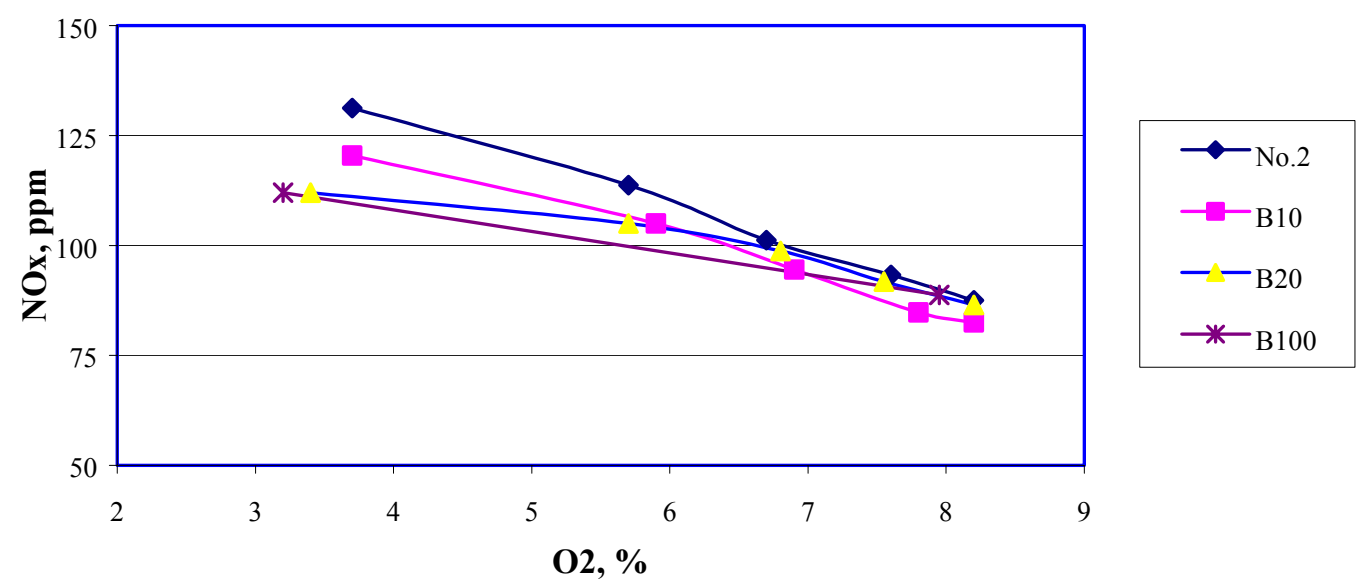

Figure 6. NOx emission from the Residential Boiler Tests

\subsection{Commercial Boiler Tests}

These steady state tests were conducted in a hot water boiler of 'commercial' size, which can supply hot water or steam and has a nominal rating of 1.8 million Btu per hour. A standard retention head burner was used with a nozzle rated at $7.0 \mathrm{GPH}$ and a $70^{\circ}$ solid cone spray. The fuel pump pressure was set at 150 PSI as recommended by the burner manufacturer and at this pressure, the fuel oil firing rate measured was $8.05 \mathrm{GPH}(1.12$ million Btu per hour). The boiler steady state conditions were defined by steam output conditions of $5 \mathrm{psig}$ and $100^{\circ} \mathrm{C}$. The boiler was started up and warmed to the steady state conditions on \#2 fuel oil. The fuel input was then switched to the 'blend' under test and the measurements were taken when steady state was reached again. The tests were conducted with the same small positive draft in the stack of about 0.15 inches of water to avoid skewing of the stack measurements by intrusion of extraneous room air. The burner has different air settings that can be set to give different excess air levels for combustion and the tests were conducted at the same four settings for the stock fuels and the blends. Figure 7 is a photograph of the set up for the commercial boiler tests. 


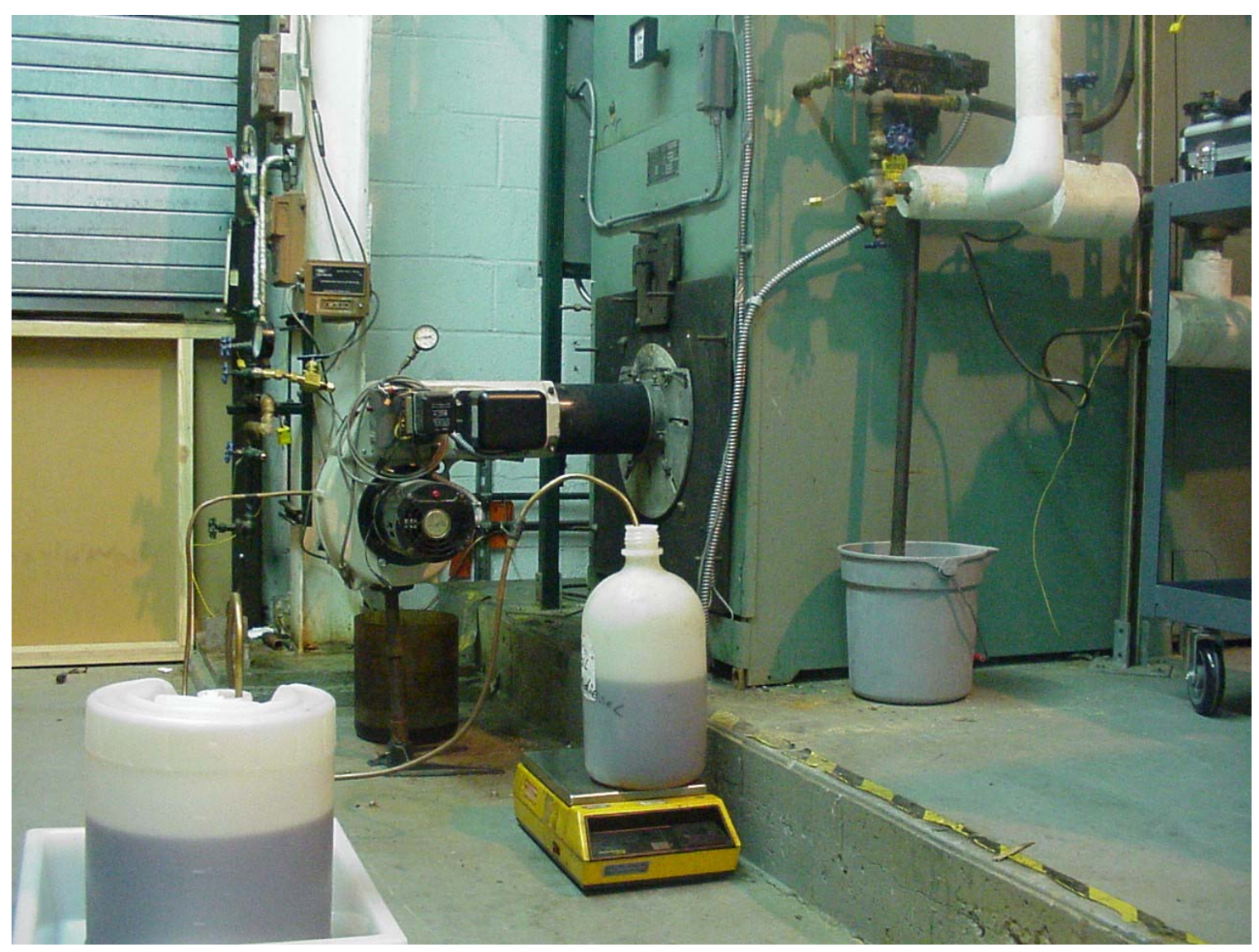

Figure 7. Commercial Boiler test setup.

\subsection{Commercial Boiler Test Results}

A general observation in these tests is that the smoke levels were lower with increase in the amount of biodiesel in the blend, as in the residential boiler tests. The results for the NOx emission are given in Figure 8 below. We find that there is significant reduction in the NOx levels with increasing amount of biodiesel in the blend with fuel oil. 


\section{NOX VS. O2 for Commercial Boiler}

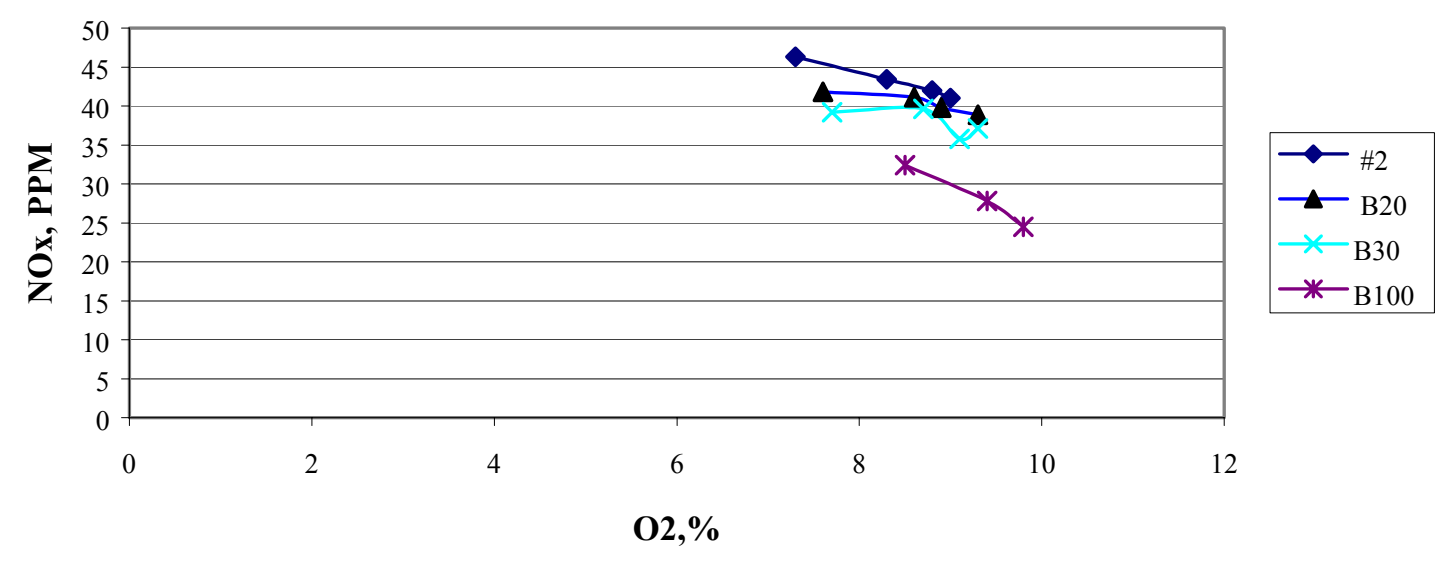

Figure 8. NOx in the Commercial Boiler.

\subsection{Field Tests in homes}

Following the research reported above, the New York State Energy Research and Development Authority (NYSERDA) decided to launch a field test of a B20 blend. This is being carried out at Abbott and Mills of Newburgh, New York. The cooperation of about one hundred customers who were willing to be participants was enlisted. The equipment consists primarily of a variety of boilers and different types of burners. The storage tanks are primarily 275 gallon tanks in basements, but there are also a few above ground and buried tanks outside the heated space. The Biodiesel is delivered by tanker, and stored in a large tanker trailer in a heated 'warehouse'. It was blended at the B20 ratio by metering it to the delivery tanker set apart for this use and then adding the fuel oil, thereby 'splash mixing' the two. The blend was delivered to the selected homes in the normal delivery pattern. The boilers were or had been serviced in the normal annual cycle and no changes were made to any of the equipment. At the time of this writing, about 55,000 gallons of the blend, which translates to about 11,000 gallons of biodiesel, have been delivered.

Approximately one hundred Abbott \& Mills customers have been participating in the testing. These customers have been with Abbott \& Mills on an average of nine years. Abbott \& Mills has been tracking fuel related service calls, and the number of filters changed per gallon of fuel delivered. All results to date have been normal with no significant changes.

During the test period, single digit outside temperatures have been recorded six times. Even though there are fifteen above ground outside fuel oil tanks in this customer group, there have been no recorded cold weather related service calls. 
Tune-ups that are regularly scheduled have not been changed. Technicians have been asked to report anything unusual. So far, the only comment has been "It smells a little different when I open up the filter".

Bottom samples were taken from a sample of tanks at the start of the test and will be compared with similar samples taken at the end. Nozzles and filters will also be collected and analyzed.

The only customer complaint received was a customer calling in about this great test that her neighbor was doing and why she was not asked to do it. After checking, she was informed that her home had been part of the test for the previous six months, a fact that her husband had forgotten to mention!

\subsection{Further Activities}

The cost of biodiesel, which currently is higher than that of diesel or heating oil, could discourage its use despite some of its attractive features. Hence, there is a need to find liquid biofuels for use as boiler fuels that do not necessarily have to meet the ASTM specification in its entirety and so could be cheaper potentially. NYSERDA has initiated research to do this and a project has been started with NOCO Energy Corp and Brookhaven National Laboratory, along with Archer Daniels Midland (ADM). ADM generates a byproduct in one of their processes that has broadly the properties of biodiesel with some departures from ASTM D6751-02. Brookhaven National Laboratory has begun testing blends of this biofuel in heating oil in essentially the same manner as described above for biodiesel. The results so far seem to indicate, that combustion performance, perhaps not surprisingly, is similar to that with biodiesel blends. We are also proposing that there may be benefits in blending this biofuel with Residual or No. 6 oil for boiler/furnace applications. This work is in preliminary stages.

We are exploring the possibility of further field tests in residential and commercial settings with different blends. There are also proposals to determine some of the potential benefits of using biodiesel to reduce fine particulate emissions.

\subsection{Acknowledgements}

The work at Brookhaven National Laboratory with the biodiesel in space heating applications was initiated with funding by the National Renewable Energy Laboratory and we thank the program manager Dr. K. Shaine Tyson for encouragement and support. We thank Mr. Ray Albrecht, the program manager at NYSERDA for constant encouragement, and NYSERDA for funding of the continuation of the biodiesel testing and for the work with biofuels. 
Paper No. 02-07

An Examination of Oil Burner Flue Gas Composition, Emissions and Testing Technologies

Wesley Mellon, Engineering Manager

David D'Amico, Project Engineer

Peter J. Cullen, Technical Service

Bacharach, Inc.

621 Hunt Valley Circle

New Kensington, PA 15068

Phone: 724-334-5000/800-736-4666

Fax: 724-334-5001

E-mail: petec@bacharach-inc.com

Internet: www.bacharach-inc.com 


\title{
An Examination of Oil Burner Flue Gas Composition, Emissions and Testing Technologies
}

\author{
Contributing Bacharach Team Members: \\ Wesley Mellon, Engineering Manager \\ David D'Amico, Project Engineer \\ Peter J. Cullen, Technical Service
}

\section{Scope:}

The intent of this paper is to examine oil burner flue gas composition. Emphasis will be placed on formation of oxides of nitrogen and sulfur oxides in the flue gases. We will detail the latest technologies for the measurement of the concentrations of these emissions and outline proper measurement procedures. Current governmental regulations and testing requirements will be outlined with an explanation of the combustion analysis equipment required to accurately measure flue gas emissions to ensure code compliance.

\section{Oil Burner Flue Gas Emissions:}

Combustion of fuel oil will result in the generation of flue gas that can be broken down into the following nine components:

- Oxygen

- Carbon monoxide

- Carbon dioxide

- Nitrogen

- Oxides of nitrogen

- Sulfur oxides

- Water

- Hydrocarbons

- Particulate matter

Of these nine, we will concentrate on nitrogen oxides and sulfur oxides emissions. These emissions are commonly referred to as "NOx" and "SOx"

\section{Nitrogen Oxides Emissions:}

Nitrogen oxides emissions are a combination of nitric oxide (NO) and nitrogen dioxide (NO2). For years the prevailing thought was that in-stack NOx was composed of 95\% NO and 5\% NO2. However, through further studies and testing it has been determined that this may not be the case, and that $\mathrm{NO} 2$ can make up a greater portion of the total NOx. Therefore, it has become important to measure both NO and NO2 and understand how they are generated. In the fuel oil combustion process the formation of nitrogen oxides occurs in a number of ways. The first results from thermal fixation of the nitrogen in the combustion air and is called "thermal NOx". There are three major factors that determine the quantity of the thermal NOx generated: 
1. The peak flame temperature.

2. The extent of the fuel air mixing that occurs.

3. The time duration the flue gas is exposed to the peak flame temperature.

If there were an increase in any of these three factors, higher NOx production would result.

The second nitrogen oxide emission results from the concentration of nitrogen in the fuel oil and is called "fuel bound NOx". The quantity of fuel NOx generated will be a direct result of the concentration of nitrogen in the fuel. The higher the fuel bound nitrogen concentration, the higher the percentage of fuel bound NOx generated. Generally, residual oils have a higher percentage of fuel bound nitrogen than does distillate oils so they will generate more fuel bound NOx. Typically $20 \%$ to $80 \%$ of the fuel bound nitrogen is converted to NOx. Fuel bound NOx can be generated to the extent that it is the major portion of total NOx.

There is a third NOx generation called "Prompt NOx". The generation of prompt NOx is a result of a chemical reaction, which occurs between the nitrogen in the combustion air, and the hydrocarbon in the fuel oil. This occurs only in the low flame temperature stages of fuel oil combustion and results in a minimal percentage of the total NOx generation.

NOx generation is a major concern of regulatory agencies due to the fact that NOx emissions have a direct link to the production of unwanted ground level ozone. When combined with Volatile Organic Compounds (VOC's) the result is smog production. NOx emissions also contribute to the formation of acid rain. Smog and acid rain production will result in environmental damage and poses health concerns as well.

\section{Sulfur Oxides Emissions:}

Sulfur oxides emissions are a combination of sulfur dioxide ( $\mathrm{SO} 2)$ and sulfur trioxide (SO3) and are commonly referred to as "SOx". The vast majority of the SOx generated, upwards of $95 \%$, is $\mathrm{SO} 2$. In the fuel oil combustion process the formation of sulfur oxides is a result of the oxidation of the sulfur contained in the fuel oil. The concern of the quantity of SOx generated is that sulfur oxides emissions combine with the water vapor contained in the flue gas or in the atmosphere to form a sulfuric acid mist. Airborne sulfuric acid has been detected in smog, acid rain and even snow. This acid is extremely corrosive and poses a danger to the environment.

\section{Emission Regulations on NOx and SOx:}

The original Clean Air Act was passed in 1963. In 1970, revisions established the basis for the national air pollution control program. The revisions of 1990 created the most far-reaching regulatory increases on emissions reductions, and we refer to these amendments as the 1990 Clean Air Act. While the Clean Air Act is a Federal Law covering the entire country, the states are charged with a great deal of the responsibility of carrying out the Act. Each state must develop a state implementation plan (SIPs) that explains how a state will do its job under the Clean Air Act. The EPA must approve 
each SIP, and if a SIP is not acceptable, the EPA can take over enforcing the Clean Air Act in that State. The South Coast Air Quality Management District of California is perhaps the best-known emission regulatory agency because of the aggressive approach they adopted by establishing strict limits on emission levels. The smog issue in California helped drive these strict regulations in an attempt to curb not only smog generation but also ground level ozone.

Several areas of the United States have been designated as ozone non-attainment areas. A designation of non-attainment means that this locality failed to meet the standards set forth in the National Ambient Air Quality Standards (NAAQS) established by the United States Environmental Protection Agency. Among the Oilheat States on this list are Massachusetts, Rhode Island, Connecticut and areas of New Hampshire, all listed as serious non-attainment areas. New York, New Jersey and parts of Pennsylvania have been classified as extreme and severe non-attainment regions.

An examination of the emissions regulations in many of the oil using states points out the difficulty states are having in developing a comprehensive plan for dealing with flue gas emissions. Many of the states regulations mirror that of another state. A small change in the minimum input requirement or a small change in what is considered Best Available Control Technology (BACT) is all that separates requirements from state to state. BACT has been used as a "catch-all" when states did not have specification for emission regulations. The revisions of The Clean Air Act in 1997 introduced the term Maximum Available Control Technology (MACT). While different in terminology the underlying goal is to utilize the most advanced control technology to minimize emissions. The good news is that commercial/industrial burner manufacturers have taken the lead in developing control and burner technologies to keep the industry ahead of regulatory mandates by showing sincere effort to develop ever improving technology.

\section{Here is a partial list of current state emission regulations in heavy oil consuming states:}

\section{-MASSACHUSETTS}

BACT (Best Available Control Technology) on new boilers over 10MMBTU input. BACT is $30 \mathrm{ppm}$

-CONNECTICUT

Regulates NOx at 180ppm

-NEW JERSEY

BACT on new boilers over $20,000 \mathrm{lbs} / \mathrm{hr}$

New Jersey DEP BACT is $30 \mathrm{ppm}$ 
-NEW YORK

NYS DEC limits NOx to $0.1 \mathrm{lbs} / \mathrm{mmbtu}$ on all boilers 500hp and over

NYC DEP requires permits on all boilers.

-PENNSYLVANIA

Limit is 30ppm for new boilers over $350 \mathrm{HP}$

In recent years we have seen a trend towards lowering both the maximum allowable emission level as well as imposing these limits on combustion systems having lower firing rate inputs.

All NOx measurements must be corrected to 3\% oxygen content in the flue gas measured. This method of correcting to a know oxygen content allows for a consistent measurement standard by which comparisons can be made and adherence to regulations can be monitored. The following formula is used for correcting NOx emissions to $3 \%$ $\mathrm{O} 2$ :

$$
\operatorname{NOx}(3 \% \text { O2 })=\operatorname{NOx}(\text { measured }) * 17.9 /(20.9-\text { O2\% }(\text { measured }))
$$

Advanced Test Equipment Technology and Proper Methodology For Achieving Test Data Accuracy.

In years past chemiluminescent testing equipment has been the predominant method employed for measuring NOx emissions. Today, however, dramatic advances in electrochemical sensor technology combined with the addition of advanced measuring techniques and equipment have paved the way for accuracy, dependability, durability and equipment cost reductions in the new environmental-combustion efficiency analyzing equipment.

The Bacharach ECA450 (Environmental Combustion Analyzer) is one example of the current state of the art in testing technology. The ECA450 is designed to incorporate the latest advancements in sensor technology with sample conditioning capabilities to bring testing accuracy to new heights while simplifying the process. The ECA450 has electrochemical sensors to measure $\mathrm{NO}, \mathrm{NO} 2$ and $\mathrm{SO} 2$. These sensors allow for direct analysis of each of the gases in the flue gas sample. Measuring NO2 directly instead of indirectly eliminates underreporting due to losses in conversion factors. The NO and $\mathrm{NO} 2$ sensors are designed to be accurate to within $5 \%$ of the reading or $5 \mathrm{ppm}$. The SO2 sensor is designed to be accurate to within $5 \%$ of the reading or $10 \mathrm{ppm}$. 


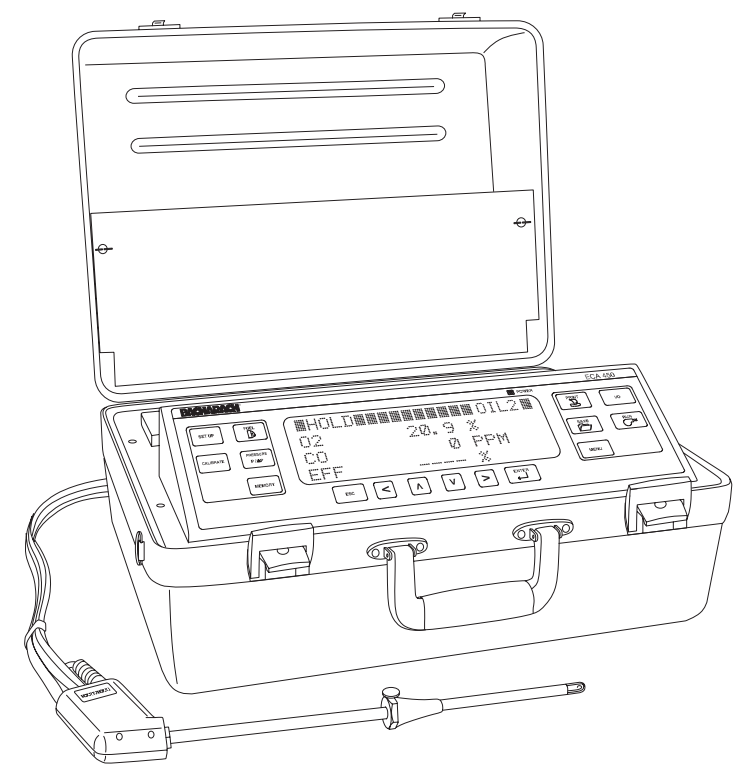

\section{Flue Gas Sample Conditioning:}

Sample condition technology is another key component necessary to ensure measurement accuracy. Standard probe and hose assemblies incorporate a water trap and filter that the flue gas sample must pass through. These types of probe assemblies provide the analyzer with a saturated combustion sample that can be used for accurate measurements of $\mathrm{O} 2, \mathrm{CO}$ and $\mathrm{NO}$. However, if $\mathrm{NO} 2$ and $\mathrm{SO} 2$ are to be measured accurately, some type of sample conditioning must be used. Standard probe and hose assemblies are not sufficient to accurately measure $\mathrm{NO} 2$ and $\mathrm{SO} 2$ because condensate collects in the water trap and along tubing walls, and acts to remove $\mathrm{NO} 2$ and $\mathrm{SO} 2$ from the sample. Therefore, when measuring $\mathrm{NO} 2$ and $\mathrm{SO} 2$ it is critical to prevent their exposure to condensation in the hose assembly or water trap that would result in underreporting their concentrations in the flue gas sample. To accomplish this the sample temperature needs to be kept above its dew point temperature (approximately $120 \mathrm{~F}$ for $\# 2$ fuel oil) until the water vapor can be removed from the sample. If the sample must be transported over a long distance and the sample temperature has a chance of dropping below the dew point, heated sample lines can be used to keep the sample warm. The sample is then delivered to a Peltier cooler which drops the sample temperature below the dew point, causing the water vapor to change phase into a liquid state. The sample is then immediately separated from the liquid water. The conditioned sample is then delivered to the instrument at a dew point of approximately 45 degrees $\mathrm{F}$, and the liquid is pumped away. Below is a diagram of a Peltier cooler assembly. There are two types of sample conditioning assemblies available. The standard model is capable of handling most applications, however, a larger capacity model is also available. You must determine the amount of time you plan to be sampling the flue gas and the condensation 
that will result. If the test time is unusually long, or if you are continuously sampling and data logging you will want to have the larger capacity sample conditioning system.

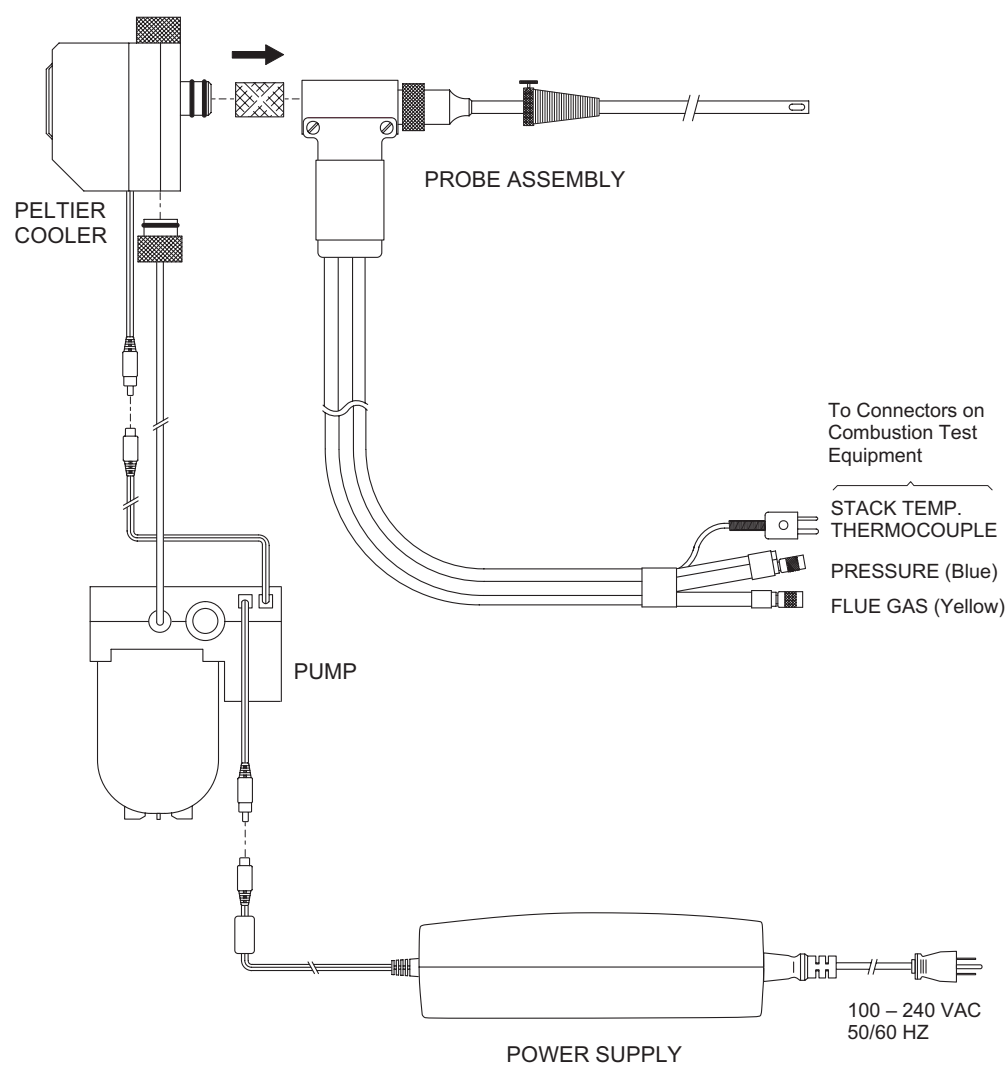

In addition to the accuracy of the ECA450, several other features have been designed into the unit to give the operator a variety of communication capabilities. Data logging capabilities allow for long term monitoring of flue gas content. Storage of the logged data can be done within the unit or the data can be downloaded to a PC for spreadsheet analysis. Repeatability is a basic test criterion. The simplicity of operation allows for rapid repeatability verification. Ease of set-up and the portability of the unit minimize testing time and maximize productivity.

The ECA450 allows for the display of pollution unit for $\mathrm{CO}, \mathrm{NO}, \mathrm{NO} 2$ and $\mathrm{SO} 2$ in parts per million (ppm), pounds of pollutant per million BTU (\#/MBTU), milligrams of pollutant per cubic meter of gas $(\mathrm{mg} / \mathrm{m} 3)$ and grams of pollutant per gigajoule $(\mathrm{g} / \mathrm{GJ})$. This flexibility simplifies adherence to a multitude of regulatory requirements.

\section{Conclusions:}

As states face increasing pressure to come into compliance with The Clean Air Act of 1990, regulations on emissions and reporting and documenting of emissions is sure to 
increase. It is imperative that we as an industry embrace current state of the art testing technologies while continuing to strive for further analysis equipment design improvement. As oil burner manufacturers invest significant research and development dollars into producing burners that will lower emission output, the importance of the accuracy of the testing of these emissions cannot be overstated. If the Oilheat Industry does not take a pro-active approach to understanding and dealing with emissions issues, we are putting our industry in peril. We must be able to demonstrate that as an industry we are committing significant research and development dollars toward efforts to reduce emissions from oil combustion products. This will demonstrate our desire to be an environmentally conscious partner in a national effort to reduce emission levels. Only through this industry wide effort can we avoid the inevitable infliction of regulatory requirements that we may find unattainable. 
Paper No. 02-08

Europe: Lowering $\mathrm{NO}_{\mathrm{x}}$ Emissions in Forced-Draft Burners -- Practical Considerations

for North America

Written by

P. Bolognin, A. Cervato, F. De Boni, B. Marracino

Riello Burners, Combustion Research Center

Legnago, Italy

Adapted and edited by

S. Williams

Riello Burners North America

2165 Meadowpine Boulevard

Mississauga, Ontario L5N $6 \mathrm{H6}$

Canada

Phone: 8004743556

Fax: 8662743556

Internet: www.riello-burners.com

E-mail: swilliams@rbna.com 


\section{Europe: Lowering $\mathrm{NO}_{\mathrm{x}}$ Emissions in Forced-Draft Burners -- Practical Considerations for North America}

Written by

P. Bolognin, A. Cervato, F. De Boni, B. Marracino

RIELLO BURNERS, Combustion Research Center, Legnago, Italy

Adapted and edited by

S. Williams

RIELLO BURNERS NORTH AMERICA, Mississauga, Canada

\section{Introduction}

In this paper, we will present our findings gained in Europe, in the area of forced-draft burners; particularly, in the development of combustion equipment designed for reduced pollutant emissions.

By the term "forced-draft burner", we refer to a burner generally using liquid or gas fuel, in which the supply of combustion air is delivered by a dedicated fan that is normally an integral part of the burner. This so-called "monobloc" design creates resistance in the combustion head, as well as the flue gas passages in the heating appliance, and overcomes the furnace pressure present in the combustion chamber.

We will briefly review the most prominent European technical and environmental regulations, both in terms of the types and degree of emissions-control they require and how those standards are evolving.

We will then present a technical overview of the family of forced-draft burners generically known as "Yellow Flame" burners. To follow, we will present a technical overview of the new, innovative generation of burners designed for low $\mathrm{NO}_{\mathrm{x}}$ emissions, which are generically referred to as "Blue Flame" burners. Among other issues, this discussion enables a number of interesting observations to be made on the correct management of forced-draft burners.

In closing, we move on to an examination of the operational technologies used in designing low $\mathrm{NO}_{\mathrm{x}}$ burners, presenting a number of critical points and highlighting particular system requirements - requirements to be kept in mind by system designers in North America. The focus will be on the required design changes based on European experiences.

\subsection{Standards: One of the driving forces behind the innovation}

Until a few years ago, the industry in Europe was generally of the opinion that the forced-draft burner could be considered a mature product; having reached a level of development that did not permit future technical improvement, with the exception of fine-tuning, quality, etc. 
In fact, recent years have brought almost total standardization of the technical solutions adopted in forced-draft burners, which has also given rise to a high level of consistency in terms of operational functions. The technology was state-of-the-art and appeared unlikely to change, unless it did so at a very slow rate.

What has transformed this state of affairs is an increasingly widely felt and common concern over environmental problems. The first concrete action to deal with these concerns was the introduction in some European countries (Germany and Switzerland, to name two) of laws and regulations regarding the limits of pollutant emissions. As a result, burner manufacturers found themselves faced with constraints, which called for a radical rethinking of the state-of-the-art technologies employed up to this point, if such regulations were to be complied with.

This evolution in standards has not only brought about changes in existing regulatory limits, but has also introduced new parameters to be monitored and therefore made subject to restrictions. Among these, the parameter that has undoubtedly contributed most to the need for new technology is the requirement to control emission levels of $\mathrm{NO}_{\mathrm{x}}$. The effect of this regulatory segmentation has been the emergence of two distinct markets, sometimes within the same country, and the development of two distinct categories of burners, each designed for compliance with one of the standards.

In other words, it is no longer possible for a single type of forced-draft burner to meet all of the standards currently in place in Europe. The pervasive shift from traditional types of burners to those producing low emissions has led to a large-scale redefinition of burner design. To meet the new criteria, burner manufacturers have had to employ radical new technology, materials and combustion techniques, with a resulting increase in costs that is significant. This technological and cost differential has created the two co-existing markets, each requiring its own type of burner.

Another aspect worthy of note is the chronological evolution of the new standards. For example, the limits for $\mathrm{NO}_{\mathrm{x}}$ provided by the German RAL-UZ9 standard, which a product must comply with to be awarded the Blue Angel environmental quality mark, have varied over the years. The upgrading of existing products to meet the new limits, although not compulsory, is mandatory if the products are to be successfully marketed. The German standard is reviewed every three years.

This volatile regulatory trend has stimulated the European burner market, which until now has been rather static. Not only must today's forced-draft burner designs meet current needs, but they must also take into account the new and more demanding regulatory measures which will be encountered in the rapidly approaching future.

\subsection{State-of-the-art: emissions of the traditional burner}

Before proceeding to analyze how the new requirements can be tackled, we should first examine the current situation in terms of $\mathrm{NO}_{\mathrm{x}}$ emissions. $\mathrm{NO}_{\mathrm{x}}$ emission values were measured during a verification campaign recently conducted in Italy, in which several samples of traditional-type burners (conventionally referred to as "Yellow Flame" burners) were utilized. Data was recorded 
according to fuel type, and field performance levels were simultaneously compared with the performance of similar burner models in the laboratory. It was discovered that measurements recorded under standardized conditions in the laboratory, were much lower than those taken under actual operating conditions in the field.

\subsection{Findings}

The majority of the $\mathrm{NO}_{\mathrm{x}}$ measurements taken in the laboratory, in conformance with the EN 267 or DIN 4787 standard and depending on output, fall within the range of 0.09 to 0.12 lbs/MMBTU. The fuel used had organic nitrogen content of about $0.05 \% \mathrm{wt}$; specific heat load was maintained at around $96,600 \mathrm{BTU} / \mathrm{ft}^{3}$ and combustion took place without flame inversion in the chamber. However, the behavior of these burners, once they were used in the field, was somewhat different. The majority of the values from the measurements taken are scattered in a range between 0.12 and $0.18 \mathrm{lbs} / \mathrm{MMBTU}$. The dispersion can be attributed to considerable inconsistency in the aforementioned parameters: a different organic nitrogen content in the fuel, varying specific heat loads (which can reach values of over 193,200 BTU/ $\mathrm{ft}^{3}$ ), the presence of flame inversion in the combustion chamber, and the high temperatures of the thermal-carrier fluid (e.g., steam or diathermic oil).

There is only a limited amount of complete laboratory data on $\mathrm{NO}_{\mathrm{x}}$ emissions measured during standardized tests in compliance with EN 267 or DIN 4787 standards. One of the reasons for this is that this type of burner is not subjected to type-approval tests. The other is because - as briefly mentioned in the introduction $-\mathrm{NO}_{\mathrm{x}}$ represents a parameter which has only recently been given the attention it deserves, even though the development of $\mathrm{NO}_{\mathrm{x}}$ burners dates back to a time in the not so distant past when these pollutants where not monitored.

Although the sample was limited, laboratory tests revealed average $\mathrm{NO}_{\mathrm{x}}$ measurements of 0.30 $\mathrm{lbs} / \mathrm{MMBTU}$, corresponding to values in the field, which ranged from 0.30 to $0.60 \mathrm{lbs} / \mathrm{MMBTU}$. The field results were strongly weighted by the differing organic nitrogen content in the fuel, which was so variable as to make the amount of the emissions unpredictable, regardless of the characteristics of the burner or heating appliance used.

\subsection{The-state-of-the-art: emissions of the Low NO burner}

Unlike traditional-type burners, Low $\mathrm{NO}_{\mathrm{x}}$ type installations are practically non-existent in Italy, which meant the monitoring of this type of liquid fuel burner had to be performed in Switzerland, on a relatively limited number of systems all fueled by light-oil with limited outputs (1.36 MMBTU/hr).

\subsection{Findings}

All the laboratory tests produced emission values below $0.07 \mathrm{lbs} / \mathrm{MMBTU}$ (the limit for Swiss approval according to LRV '92 is 0.07 lbs/MMBTU @ 3\% $\mathrm{O}_{2}$ ). However, the general lower limit of these values was observed at $0.05 \mathrm{lbs} / \mathrm{MMBTU}$. The working conditions were the same as those established for the laboratory tests conducted with traditional-type light-oil burners. Although the outputs here were generally lower, the corresponding emission values were higher. 
This is the result of the different combustion technology used. These tests were conducted with burners incorporating flame inversion in the combustion chamber.

In the field tests, the resulting range of emission values is narrower (varying from 0.06 to 0.09 $\mathrm{lbs} / \mathrm{MMBTU}$ ) than is the case with traditional-type burners. This is due in large part to the applicable Swiss legislation, which calls for annual testing by the "chimney sweeps" and local municipal inspectors. Failure to comply with the limits in force results in the obligation and cost of taking corrective measures, which often results in a replacement of the burner.

Another reason for this uniformity is that the average Swiss installer is more up-to-date regarding technological innovation, and is normally equipped with a portable flue gas analyzer. This means that when starting up systems in the field, and during subsequent maintenance work, main operational parameters such as emissions, excess air and flue gas temperature can be checked and reset when necessary.

The remaining differences between the field and laboratory tests had to do with the different nitrogen content of the fuel and the different architectures of the combustion chambers. The specific heat loads on the other hand, were quite uniform and close to those reached in the laboratory. More importantly, the results show that with reference to traditional burners, we can quite safely say that the current Low $\mathrm{NO}_{\mathrm{x}}$ technology enables nitric oxide emissions to be halved under actual field conditions.

It should be noted that while $\mathrm{CO}$ emissions generally remained very low (below 0.012 $\mathrm{lbs}$ (MMBTU) in both the laboratory and field tests, the dispersion of the values was affected by different working conditions (e.g., flame inversion in the combustion chamber). This is an important factor in determining the best balance between optimum values for $\mathrm{NO}_{\mathrm{x}}$ emissions and those for $\mathrm{CO}$ emissions. The techniques used for the reduction of $\mathrm{NO}_{\mathrm{x}}$ sometimes involve a certain critical limit on $\mathrm{CO}$ emissions.

\subsection{Low $\mathrm{NO}_{\mathrm{x}}$ burner design}

At this point, it seems appropriate to briefly illustrate an example of a Low $\mathrm{NO}_{\mathrm{x}}$ oil-fired burner combustion head. The example in question is of course not entirely representative of the various solutions currently available on the market, but is sufficiently informative to provide some understanding of the remarks made.

Figure 1 features a schematic representation of a combustion head design used in Low $\mathrm{NO}_{\mathrm{x}}$ lightoil burners up to 1.2 MMBTU, and based on a rather groundbreaking concept. The principle of operation calls for the total combustion airflow to be divided into three streams, with the external one generating a very fast annular jet, which exploits the entrainment phenomenon to suck air back by way of the surrounding environment, thus establishing recirculation inside the chamber, of the flue gases generated by combustion. These gases mix with the combustion air during the combustion reaction, enabling the flame temperature to be kept down and limiting the formation of thermal $\mathrm{NO}_{\mathrm{x}}$. 
Additional reduction in the emission of $\mathrm{NO}_{\mathrm{x}}$ is obtained by injecting the fuel in the external region of the combustion airflow. In this case, the fuel droplets with smaller diameters are drawn forward, diluting the combustion process to further decrease the flame temperature. The fuel droplets with greater diameters (therefore mass and kinetic energy) escape the air jet, are caught up in the recirculated gas flow and subjected to partial evaporation before combustion.

This evaporation causes part of the fuel to be burnt in its vapor phase, and at the same time decreases the dimensions of the larger fuel droplets, thus avoiding the cracking of their nuclei which reduces (and in most cases, eliminates) the formation of soot inside the flame.

Together, these two effects (present in most Low $\mathrm{NO}_{\mathrm{x}}$ light-oil burners) generally lead to the flame taking on a bluish color (similar to gas-fueled flames). Hence, the name "Blue Flame" burners.

Compared to a traditional-type burner, the greater load losses of the Low $\mathrm{NO}_{\mathrm{x}}$ combustion head dictate the need for a ventilating structure with higher performance characteristics than Yellow Flame burners of equivalent output. Also, the different composition of the light spectrum emitted by the flame calls for measurement systems that are very different from the photocells commonly used with Yellow Flame burners.

\subsection{Low $\mathrm{NO}_{\mathrm{x}}$ systems: some critical points}

The type of combustion head described in the section above is designed to effectively oxidize the fuel without oxidizing the nitrogen present in the combustion air and in the fuel itself. However, maintaining good performance levels in a system powered by a Low $\mathrm{NO}_{\mathrm{x}}$ forced-draft burner presents some difficulties. This section discusses how performance can be maintained with appropriate burner and heating appliance combinations, and suggests what some future objectives of research in this area might be.

\subsection{Specific heat load}

In the past, a typical approach, aimed at keeping the cost of the heating appliance down, was to reduce the size of the combustion chamber as much as possible, without sacrificing heat output. High specific heat loads encouraged the complete oxidation of the fuel, reducing the emission of carbon monoxide and other incombustible elements to negligible levels. This obvious benefit notwithstanding, high heat loads in the combustion chamber lead to increased flame temperatures, which increase the production of $\mathrm{NO}_{\mathrm{x}}$.

Based on the data currently available, we can state that with existing Low $\mathrm{NO}_{\mathrm{x}}$ technologies the maximum allowable specific heat load for maintaining good performance levels is equivalent to $96,600 \mathrm{BTU} / \mathrm{ft}^{3}$. This means that correct combination with a Low $\mathrm{NO}_{\mathrm{x}}$ burner must involve a more generously sized combustion chamber, compared to traditional solutions for which, as we have mentioned, specific heat loads of 193,200 BTU/ $\mathrm{ft}^{3}$ are easily reached. Of course, this means increased costs as far as the heating appliance is concerned. 


\subsection{Architecture of the combustion chamber}

Still on the subject of keeping costs down, a widely adopted solution, especially in the field of water boilers for heating, is that involving the development of the combustion process in the central part of the furnace, creating a subsequent inversion of the flow of flue gases which run back through the combustion chamber, "enveloping" the flame and passing into the heat exchanger at the point where the burner is mounted.

The creation of long, narrow flames and the sufficient introduction of the burner head into the combustion chamber have in the past enabled burner and heating appliance combinations that meet a variety of needs, but not that of reducing $\mathrm{NO}_{\mathrm{x}}$ emissions. On systems incorporating Low $\mathrm{NO}_{\mathrm{x}}$ burners, this combustion chamber architecture may prove to have a detrimental effect for at least a couple of reasons.

The first relates to the process described above. The flow of flue gases, which runs back through the furnace enveloping the flame, does in fact confine the flame to a volume smaller than the actual combustion chamber volume, considerably increasing the real specific heat load. In addition, with respect to the heat exchange, the flue gases (rich in $\mathrm{CO}_{2}$ ) constitute a sort of insulating screen between the flame and the walls of the heating appliance, causing an additional increase in the temperature in and around the flame.

The second reason lies in the complex aerodynamics generated by Low $\mathrm{NO}_{\mathrm{x}}$ type combustion heads. These aerodynamics give rise to the recirculation of the flue gases which, on being drawn back into the combustion chamber, are reintroduced into the flame resulting in the fractionation of the fuel and combustion air supply. This fractionation affects the combustion process, favoring certain chemical kinetic paths over others.

Good performance levels are without a doubt encouraged by the presence of a unidirectional flow, and disturbed by the presence of return flows, which, in most cases, alter the aerodynamics generated by Low $\mathrm{NO}_{\mathrm{x}}$ combustion heads. Evidence of this was found when comparing the emission of nitric oxides generated by two Low $\mathrm{NO}_{\mathrm{x}}$ burners coupled, in a first instance, with a combustion chamber where the flue gases escape from the bottom, and in a second instance using a similar combustion chamber in which flame inversion was set up. In the second instance, emissions increased by up to $50 \%$.

Knowledge of the above dynamics has encouraged the emergence in the Low $\mathrm{NO}_{\mathrm{x}}$ market of socalled 3-pass boilers, which position the flue gas outlet at the bottom of the furnace from which the gases then pass into the convective heat exchange compartment. Once again, increased efficiency in limiting emissions corresponds to a greater financial burden, deriving from the increased complexity of construction and testing of this type of heating appliance.

\subsection{Combustion instability}

The need to reach a compromise between oxidizing the fuel without oxidizing the nitrogen, the resulting use of flue gas recirculation and the related reduction of areas in which oxidation occurs inevitably lead to latent instability in the combustion process. 
Testing has revealed the progress of the pressure measured in the furnace and its output spectrum for the three different types of burners: Yellow Flame, Blue Flame and a third type known as "Deep Blue Flame" - a burner still in the experimental phase, which manages to cut $\mathrm{NO}_{\mathrm{x}}$ emissions in half compared to the average Blue Flame burner.

These measurements indicate the need to gradually switch from traditional-type burners to those producing less pollution. As we progress from the Yellow Flame to the Deep Blue Flame burner, the amplitude of the pressure waves generated by the combustion process increases, and at the same time we witness a compression of the spectrum, sliding towards increasingly low values. Greater amplitudes often mean the emergence of combustion instability phenomena which can limit the operational elasticity of the heating system, making it more sensitive than traditionaltype systems to a variety of parameters, such as environmental conditions (particularly temperature and density of the combustion air), the heating equipment flue-gas exhaust duct system's own frequencies, the properties of the fuel (in particular, for liquid fuels the viscosity and geometry of the spray, for gaseous fuels the presence of inert elements such as nitrogen, water vapor or carbon dioxide).

This greater sensitivity of Low $\mathrm{NO}_{\mathrm{x}}$ burners to external factors is contributing towards the growing use of modular systems as a valid solution, i.e., pre-combined burner and heatingappliance assemblies with specific heat loads and combustion chamber architectures that are consistent with the provisions discussed above. Each component is developed specifically for combination with the other, or at least subjected beforehand (by either the burner or heating appliance manufacturer) to operational tests. In the coming years we will most certainly witness an increase in the versatility of the new Low $\mathrm{NO}_{\mathrm{x}}$ systems.

\subsection{Electrical power consumption}

When previously describing the Low $\mathrm{NO}_{\mathrm{x}}$ combustion head, we mentioned how the head design creates considerable load losses in the combustion air circuit, and how this consequently calls for ventilating structures which are oversized compared to traditional-type Yellow Flame burners of equivalent output.

This is generally true for all current commercially available Low $\mathrm{NO}_{\mathrm{x}}$ burners. One of the main consequences of this adjunct feature on such burners is an increase in electrical power consumption. As an example, when comparing the rated data of the electric motors of a number of Yellow Flame and Blue Flame burners (produced by various manufacturers) at various heat capacities, initial observations reveal an almost linear trend, with only slight dispersion, in the case of traditional burners, while the Low $\mathrm{NO}_{\mathrm{x}}$ burners are characterized by considerable dispersion. This is additional evidence of how a consolidated and uniformed technology in the case of Yellow Flame burners contrasts with the large number of technical solutions - often rather different from each other - adopted by the manufacturers of Blue Flame burners.

Nonetheless, the most important consideration is that switching from a Yellow Flame to a Blue Flame burner will generally result in an increase in electrical power consumption of $100 \%$ or more. Whether the harmful emissions are created by the burner in its combustion phase, or by the 
thermoelectric power plant producing the extra power needed, is somewhat of a moot point. Suffice to say that it will be necessary to allow for these increased energy requirements in the design phase of the electrical systems for Blue Flame burners.

\section{Conclusions}

Having reached the end of this brief summary, a number of considerations seem clear.

The environmental concerns that exist in Europe also exist in North America. Therefore, in North America, despite the passive appearance of legislators and the relative inactivity on the part of manufacturers and system designers involved in the development of combustion technology, in the not-too-distant future we will most likely follow in Europe's footsteps. More rigorous restrictions regarding pollutant emissions generated by combustion processes will be imposed throughout North America.

At present, by taking advantage of proven and available technologies, it is possible to reduce $\mathrm{NO}_{\mathrm{x}}$ emissions by at least $50 \%$, by directly controlling the combustion process using Low $\mathrm{NO}_{\mathrm{x}}$ burners combined with suitable heating appliances.

For the near future, an important focus will be the development of suitable methods to effectively control the pressure fluctuations induced within the combustion chamber. It is apparent that the appliance manufacturers will be forced to increase their current combustion chamber sizes, to lower and control heat loading from within. This design change will assist in maintaining both combustion and flame stability. Unfortunately, this change, coupled with the increased demand for power consumption, will raise overall system costs.

Looking into the longer term, to truly tackle the emissions problems, it appears that joint design and product development initiatives between burner and heating appliance manufacturers will be both desirable and necessary.

And finally, to maintain the "rated" performance levels, being the standard levels measured in the laboratory, important consideration will have to be given to the proper installation and maintenance of the burners and heating appliances. In the absence of effective regulation in this area, education and training of installation and service technicians must certainly be encouraged and promoted. 


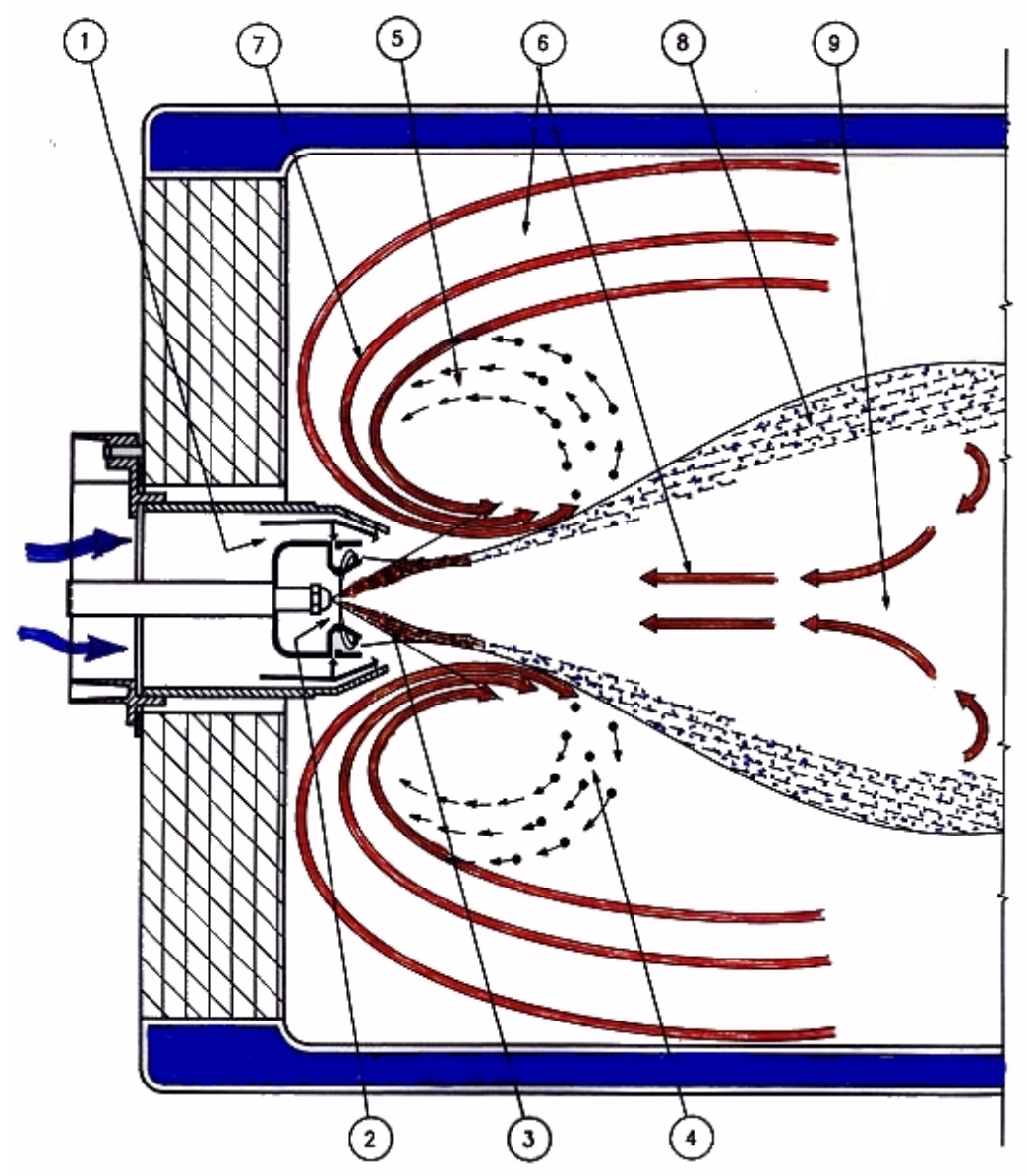

Fig. 1 - Schematic representation of the operation of a Blue Flame type light-oil forced draft burner combustion head $(614,100$ BTU/h - 1,194,200 BTU/h): 1 - Combustion air $\mathbf{2}$-Flame stabilization area $\mathbf{3}$ - Fuel spray $\mathbf{4}$ Spray drops with larger diameters $\mathbf{5}$ - Vaporized fuel $\mathbf{6}$ - Recirculated flue gases $\mathbf{7}$ - Flue gases/Vaporized fuel mixture 8 - Combustion with Air / Vaporized fuel / Recirculated flue gases mixture 9 - "Cold" nucleus of the flame. 
Paper No. 02-09

Low Cost/No Cost Techniques to reduce NOx in Residential Oil Burners

Charles Feldman, David Engley, Michael Shayda and Kenneth Stadtlander Carlin Combustion Technology, Inc. 70 Maple St.

East Longmeadow, MA 01028

Phone: 413-525-7700

Fax: 413-525-8306

E-mail: info@carlincombustion.com

Internet: www.carlincombustion.com 


\section{Low Cost/No Cost Techniques to reduce NOx in Residential Oil Burners}

\section{Introduction}

Emissions $\left(\mathrm{CO}_{2}\right.$, Particulate PM-10, Particulate PM 2.5, $\mathrm{CO}$ and NOx) from large oil burners, large gas burners, and other fossil fuel burning equipment has been a concern for many years now. Driven in large part by the Clean Air Act, the National Ambient Air Quality Standards and other state air quality rules, large high firing rate equipment has been regulated or controlled to some degree since the early 1980's. The first to come under scrutiny were the large electric power plant burners and similarly large-size facilities. From that starting point, focus trickled down over the years to lesser firing rate burners through to the commercial industrial size range.

In addition to commercial industrial, power plant and other large equipment, California has for several years now regulated the NOx emissions from residential gas fired water heaters and other residential gas fired equipment. Texas now appears to be following in California's footsteps, adopting the current South Coast Air Quality Management District NOx Emissions Rules.

In these states and other areas where the lowest NOx regulations are in place, virtually no oil is being burned today. But then again, these areas were never big oilheat markets. They are typically warmer climates with low space heating requirements. Moreover, in these regions when oil was used it was usually limited to commercial and process applications or as a backup fuel. Consequently, the oilheat industry has not been impacted very heavily by these regulations; and as a result, very little work has been done to develop a residential low NOx oil burner.

Where regulations exist, the techniques used to lower and control NOx emissions, especially in the large appliances, are well know and well understood. And at this point, the concepts are well proven with thousands of field installations that have employed various strategies, but primarily limited to larger gas-fired equipment.

This paper attempts to explore ways to reduce NOx emissions in residential oil burners using conventional burner designs and applying these simple well known and well understood emissions reduction techniques and or the use of alternate fuels. The intent here was to discover if it is possible to achieve meaningful NOx reduction using current equipment designs and making relatively minor, no cost, or perhaps more realistically, low cost modifications to that equipment. We wanted to look at possible changes to things like:

- Burner Set-Up

- The Burner Firing Rate

- The Burner Control Protocol

- The Fuel Specifications

- The Heat Exchanger Type

- Heat Exchanger Heat Release Rates

- Heat Exchanger Designs 
We wondered if the addition of a simple NOx reduction technique or a combination of strategies could result in significant NOx reduction without significant added cost. We felt that $10 \%$ to $15 \%$ reduction in emissions would be significant, while choosing not to assign any dollar value to define significant added cost for reasons that will be apparent later.

We ultimately decided to look at the following NOx reduction possibilities:

- $\quad$ Burner Set-Up With Low (15\%) and High (50\%) Excess Air Levels

- $\quad$ Reduced Firing Rates

- Interrupted vs. Constant Ignition

- Low Sulfur Oil (.05\% by Weight)

- Ultra Low Sulfur Oil (.005\% by Weight)

- Various Bio-Fuel Blends

- B45

- B10

- B20

- B30

- $\quad$ Induced Flue Gas Recirculation (IFGR)

As is often the case, our findings were not always as expected. In fact, some were difficult to understand at first, but after some study were reasonable and explainable.

In quantifying rates of reduction, the first question that arose was what is the baseline for NOx emissions from a typical oil burning appliance? So, our first study was to establish that baseline. To accomplish this task, we used test data developed in our Combustion Lab at Carlin and solicited the help of a local oil dealer to help gather field data. Automatic TLC Division of Heating Oil Partners of Hartford, Connecticut volunteered to assist in this effort, and we thank them for their help and cooperation.

The data collected by Automatic TLC was randomly chosen. Carlin provided a portable analyzer capable of measuring NOx. Automatic TLC had their field service supervisors collect the data during the normal course of their service and installation activities. See Appendix A for combustion analyzer specified tolerances.

\section{NOx:}

\section{Background}

NOx is a generic term used to describe two (2) different chemical compounds. These two (2) compounds are $\mathrm{NO}$ (nitric oxide) and $\mathrm{NO}_{2}$ (nitrogen dioxide). In the combustion process where NOx is formed, there are three (3) basic constituents of NOx. They are: prompt NOx, thermal NOx, and fuel-bound nitrogen.

\section{Prompt NOx:}

Prompt NOx is the NOx that is generated as part of the combustion process itself. It is the byproduct of the chemical reaction that results in combustion. In order to achieve combustion, 
you must have fuel, oxygen, and heat (a source of ignition). When you mix fuel oil and combustion air and provide a heat source, a chemical reaction takes place. That chemical reaction produces: heat, carbon dioxide, oxygen, nitrogen, water vapor and prompt NOx among other compounds in low concentrations including CO (carbon monoxide). This prompt NOx component is usually a very small percentage of the total NOx generated, and the most difficult to deal with. Very few burner manufacturers even attempt to control it. Some large commercial/ power plant size equipment and some atmospheric premix designs do address this constituent, and it usually results in very low single digit NOx performance.

\section{Thermal NOx:}

Thermal NOx is the NOx generated by the chemical reaction between nitrogen and oxygen at elevated temperatures, generally in excess of $1600^{\circ} \mathrm{F}$ to $1800^{\circ} \mathrm{F}$. The higher the flame temperatures the more NOx that is generated. This is the constituent of NOx that most burner manufacturers try to control. Staged air, staged fuel, FFGR (forced flue gas recirculation), IFGR (induced flue gas recirculation), internally induced flue gas recirculation and steam injection are all techniques that try to reduce peak flame temperatures thereby reducing NOx emissions.

\section{Fuel Bound Nitrogen:}

Fuel bound nitrogen is just as it says, nitrogen contained within the fuel. Typically, natural gas has little to no nitrogen while fuel oil has a nitrogen content in the range of $.02 \mathrm{lbs} / \mathrm{mmbh}$. This level of nitrogen contained within the fuel will typically add about 25 PPM to the combustion process. Adding nitrogen to the combustion process through the fuel source only provides more opportunity to create NOx.

\section{The Solution To Pollution Is Not Dilution:}

Since it is customary to measure NOx and CO in terms of PPMVD (parts per million volume dry), it is important to establish a reference point at which these measurements are taken. Higher excess air levels will produce lower NOx and $\mathrm{CO}$ measured as a percentage of the total mass flow. Therefore, a generally accepted industry standard is to reference all measured NOx and $\mathrm{CO}$ readings at $3 \% \mathrm{O}_{2}$ (approximately $15 \%$ excess air). If measurements are taken at any $\mathrm{O}_{2}$ (excess air level) other than $3 \% \mathrm{O}_{2}\left(15 \%\right.$ excess air), a mathematical correction back to $3 \% \mathrm{O}_{2}$ is necessary.

To correct any measured $\mathrm{O}_{2}$ reading to $3 \% \mathrm{O}_{2}$, you first need to calculate a NOx correction factor, then multiply the measured $\mathrm{O}_{2}$ by that correction factor. To calculate the NOx correction factor: divide $17.9\left(20.9 \% \mathrm{O}_{2}-3 \% \mathrm{O}_{2}\right)$ by 20.9 minus the measured $\mathrm{O}_{2}(17.9 /[20.9-\mathrm{X}])$. To correct the measured $\mathrm{O}_{2}$ to $3 \%$, multiply the measured $\mathrm{O}_{2}$ by the calculated correction factor.

EXAMPLE 1

Measured $\mathrm{O}_{2}=2 \%$

$17.9 /(20.9-2)=0.947 \%$

$2 \times 0.947=1.9 \% \mathrm{O}_{2}$
EXAMPLE 2

Measured $\mathrm{O}_{2}=5 \%$

$17.9 /(20.9-5)=1.126 \%$

$5 \times 1.126=5.6 \% \mathrm{O}_{2}$ 


\section{Establishing a Baseline for NOx}

Establishing a baseline or typical expected level of NOx emissions from a residential oil burner was a bit more difficult than one might imagine. While some data has been published over the years (see: "EMISSIONS CHARACTERISTICS OF MODERN OIL HEATING EQUIPMENT”, R. Krajewshi, Y. Celebi, R. Coughlan, T. Butcher \& R. McDonald, Brookhaven National Laboratory, 1990; "OXIDES OF NITROGEN (NOx) AND OIL BURNERS", T. Butcher, Brookhaven National Laboratory, L. Fisher, PE Consultant, B. Kamath, Heat Wise Inc., T. Kirchstetter, UC Berkley \& John Batey, Energy Research Center, Inc.; "EXPANDED USE OF RESIDENTIAL OIL BURNERS TO REDUCE AMBIENT OZONE AND PARTICULATE LEVELS", John Batey, Energy Research Center), we were not able to find any comprehensive broad-based study. From our own lab test data collected as part of our normal applications testing activities, we know that NOx emissions vary significantly from one heat exchanger design to another. Also, from our own observations, we know that newer heat exchanger designs, especially cast iron boilers, tend to have higher heat release rates and consequently higher NOx emissions levels than older designs. And, again from our experience, we know that residential appliances tend to emit higher NOx levels than do commercial size appliances. So, to better define this baseline, we settled upon a two-step approach.

1. We reviewed our files for existing data and began a test program to gather new data.

2. We solicited the help of a local oil dealer to gather field data for us.

The results of this testing confirmed our suspicions that the age of the burner design and the design of the heat exchanger play a major roll in NOx generation. In very general terms, older less efficient equipment tend to emit lower NOx emissions levels, while newer more efficient appliances tend to emit higher NOx levels. Also, in very general terms, heat exchangers with combustion chambers that contain refractory tend to generate higher NOx emissions than do heat exchangers with little or no refractory.

\section{Field Survey Results:}

Field surveyed units included; warm air furnaces, steel boilers, cast iron sectional boilers and oil fired hot water heaters. Among this sampling was a reasonable diverse cross section of equipment ranging from: current heat exchanger designs, to both burner and heat exchanger brands that are no longer being produced, to manufacturers that are no longer in business; see Appendix B for additional data. The average NOx emissions rate from this population was 110 PPMVD (corrected to $3 \% \mathrm{O}_{2}$ ). Other average data was as follows:

Average Firing Rate........................... 0.80 GPH

Average CO2 ..................................... 10.5 \%

Average Net Stack Temperature........................ 464 ${ }^{\circ} \mathrm{F}$

Smoke (none exceeded a trace).........89\% Measured "0" Smoke

$11 \%$ Measured a Trace

Average Combustion Efficiency....................... $78.8 \%$

Average NOx Emissions Rate....................110 PPMVD 
It should also be noted that $83 \%$ of these appliances utilized constant duty ignition controls.

\section{Lab Test Results:}

Like the field test, our lab test heat exchangers included a similarly representative cross section of designs. Included was: a cast iron sectional boiler, a steel boiler, a warm air furnace and an oil fired water heater; see Appendix B for additional data. But unlike the field test units, these units were fired to the manufacturers published rate and adjusted to minimum excess air levels (15\%), and then to maximum excess air levels (50\%). The average NOx emission rate was 170 PPMVD using constant duty ignition. The constant duty control data was chosen here in an attempt to replicate, as closely as possible, the field test lot. Other average data was as follows:

Low Excess Air (15\%):

Average Firing Rate............................. 1.00 GPH

Average CO2 ......................................... 13.1\%

Average Net Stack Temperature.......................... 456 45

Smoke .......all measured between a trace (-) and a number "1" Smoke

Average Combustion Efficiency.......................... 84.7\%

Average NOx Emissions Rate.......................165 PPMVD

High Excess Air (50\%):

Average Firing Rate................................. 1.00 GPH

Average CO2 ....................................... 10.1\%

Average Net Stack Temperature......................... 467 $47^{\circ} \mathrm{F}$

Smoke ................................all measured "zero" smoke

Average Combustion Efficiency.......................... 82.4 \%

Average NOx Emissions Rate.......................176 PPMVD

The fuel oil used for this testing, as well as all other testing of standard fuel oil, came from the same feedstock. Before testing began, we procured a large enough lot to complete all tests including the blending of the bio-fuel. This fuel oil was controlled, and segregated from the fuel we use for our routine testing activities; see Appendix $\mathrm{C}$ for additional details.

Clearly the newer equipment, with higher heat release rates and tighter, more efficient, more compact flame patterns, are generating higher peak flame temperatures resulting in higher NOx emissions. If this design trend continues, we can expect to see average NOx emissions from residential oil burners continue to rise.

\section{Interrupted vs. Constant Ignition}

As we had discovered in research done three (3) years ago, the electrical spark used to ignite an oil burner creates NOx, due to the ionization properties of the high voltage electrical arc. This NOx can be measured and was documented in our earlier study, "ADVANCED OIL BURNER CONTROL FUNCTIONALITY AND HOW IT EFFECTS OVERALL PERFORMANCE" 
(April 16, 1999). Testing for this project revisited this issue to re-verify the benefits of interrupted ignition reported in our earlier study.

Comparison testing between constant and interrupted duty ignition was performed under all test conditions, and in all cases, some reductions in NOx was observed when the spark was turned off. The magnitude of reduction varied quite widely between the various test conditions, heat exchanger type, fuel type, excess air level, and firing rate. Nonetheless, the average reduction was 11.3 PPMVD (corrected to $3 \% 0_{2}$ ).

To further define the NOx contribution added by the ignition spark, we installed a test burner in each of our four (4) test heat exchanger designs. The burners were fired without fuel, and NOx readings were taken with the spark on and with the spark off. With the spark off, in all cases, we recorded a zero NOx reading. With the spark on, our initial uncorrected readings varied from 8 to 18 PPMVD; but without a flame and combustion $\mathrm{O}_{2}$ reading, we were unable to correct the raw numbers to our $3 \% \mathrm{O}_{2}$ reference point. We confirmed, by opening and closing the burner air shutter, that higher quantities of air through the heat exchanger would change (dilute) our uncorrected NOx reading.

In an attempt to get an accurate reading, we fired one of the test burners, adjusted the air/fuel ratio to achieve a $3 \% \mathrm{O}_{2}$ concentration in the stack, and then ran the burner with the spark on, but without flame. The measured NOx level was 14 PPMVD. This testing was performed in all four heat exchangers with similar results.

From this, we can conclude that while performance will vary from one installation to another, due to other site specific factors or combinations of factors, on average, we can expect a 14 PPM NOx reduction using interrupted duty ignition. Or, using our field test baseline, roughly a $13 \%$ reduction in NOx emissions.

\section{5\% vs. 50\% Excess Air Levels}

A commonly used technique to reduce emissions in commercial industrial and larger equipment is to cool the flame in an effort to reduce peak flame temperatures. Flue gas recirculation, staged fuel, staged air, and steam injection are commonly used techniques. We wondered if high excess air levels would provide the same type of cooling effect and have a similar result.

To evaluate this theory, we adjusted the air fuel ratios for all test conditions to the same low and high $\mathrm{CO}_{2}$ levels. The low $\mathrm{CO}_{2}$ replicated a $50 \%$ excess air level, while the high $\mathrm{CO}_{2}$ replicated a $15 \%$ excess air level.

The results of this testing was counter to the theory. At higher excess air levels, the measured NOx emission rate actually increased by an average of $8 \%$. While unexpected, this result is not unreasonable considering the fact that an oil flame is usually bigger at low excess air levels and contains more soot precursors, both of which contribute to flame cooling by radiation, which limits peak flame temperatures. 
In analyzing the data further, we noted an average increase in excess air from $18.25 \%$ to $50 \%$ and an average increase in stack temperature from $456^{\circ} \mathrm{F}$ to $467^{\circ} \mathrm{F}$. A contributing factor appears to be that providing the combustion process with additional oxygen in the presence of higher temperatures more than offsets the cooling effect of the higher excess air levels. This phenomena is further supported by "low excess air" burner designs offered by some commercial industrial burner manufacturers that reduce NOx emissions by operating very close to stoichiometric air fuel ratios. These types of designs make little or no free oxygen available to combine with the nitrogen in the combustion air to form NOx. Conversely, as is demonstrated here, by adding lots of additional oxygen to the combustion process, that additional oxygen more easily finds and combines with the nitrogen present in the combustion process, and as a result, more NOx is generated.

\section{Low Sulfur Oil (.05\% by Weight)}

Low sulfur fuel oil has been experimented with quite widely in recent years. Removing sulfur from the oil reduces the sulfur oxide deposits that accumulate on the heat exchangers surfaces and maintains a cleaner heat exchanger and a higher level of heat transfer for a longer period of time. The process used to remove sulfur from fuel oil also removes some nitrogen contained in the oil as well, see Appendix $\mathrm{C}$ for additional detail. The lower fuel bound nitrogen levels should result in lower NOx emissions rates. Other testing done with low sulfur oil has documented this lower NOx emission rate phenomena. Our study here was to attempt to quantify the amount of reduction that might be expected compared to standard fuel oil.

As was expected, the low sulfur oil produced NOx emissions that were $11.9 \%$ lower than standard fuel oil. The best results were observed when firing low excess air levels (12.9\% CO2) and interrupted ignition (16\% NOx reduction), and poorer but good results under higher excess air levels (10.13\% CO2) with constant ignition (8.3\% NOx reduction).

\section{Ultra-Low Sulphur Oil (.005\% by Weight)}

If the .05 sulfur fuel oil does a reasonably good job of reducing NOx emissions, we wanted to look at the new .005 product to see if it would provide further emissions reduction opportunities, see Appendix $\mathrm{C}$ for additional details. So, we repeated the tests done for the .05 low sulfur fuel oil, and to our amazement, got better results than we had expected.

The average NOx reduction using this ultra low sulfur oil (.005) was $22.7 \%$. Better results were achieved under low excess air settings $(12.95 \% \mathrm{CO} 2)$ and interrupted ignition (average $25.6 \%$ NOx reduction), and poorer but good results under high excess air settings $(10.13 \% \mathrm{CO} 2)$ and constant ignition (average $18.1 \%$ NOx reduction).

\section{Reduced Firing Rates}

Reducing the firing rate of any piece of equipment has the effect of lowering the heat release rate. It is well documented on commercial industrial size equipment that higher heat release rates $(175,000$ to $200,000 \mathrm{BTU} / \mathrm{Ft} 3$ or higher) result in higher NOx emissions, while lower heat release rates $(125,000$ to $100,000 \mathrm{BTU} / \mathrm{Ft} 3$ or lower) translate into lower NOx emission rates. Our attempt here was to discover 
if simply lowering the firing rate would improve the emissions performance of residential appliances.

We arbitrarily picked $20 \%$ as the reduced firing rate for our testing. Knowing that most oil-fired equipment is oversized by a rather sizable margin, we felt comfortable with this magnitude of reduction. In selecting this percentage, we were mindful that we needed to be able to support the load on the appliance, while providing enough of a reduction to impact our NOx emissions rate, but not too much as to create a flue gas condensation problem. Again, all tests were repeated at a rate $20 \%$ below the manufacturers nameplate rating.

In the course of these tests, we did see a significant drop in average stack temperatures (about $10 \%$ ), and in fact, had two (2) cases where the stack temperature dropped below $300^{\circ} \mathrm{F}$. In addition, we did have a few cases where we could not achieve the desired excess air levels. And finally, despite these expected results, we did not see the expected NOx reduction. There was no measurable effect by reducing the firing rate by $20 \%$.

In one final attempt to test this theory, we tried to down-fire the test heat exchangers by $50 \%$. We were unsuccessful in our attempts to achieve acceptable combustion results with our hot water heater and our steel boiler. But, we were able to fire the cast iron sectional boiler and the warm air furnace at $50 \%$ of the manufacturers rating and at our specified test excess air levels. These test results too did not show any NOx reduction benefit to down-firing the units. There was a nominal increase in the NOx emissions at the high excess air rate; and a nominal reduction in NOx emissions at the low excess air rate. But on balance, down-firing does not appear to be a viable option.

\section{Bio-Fuel Blends}

Our experimentation with bio-fuels was instigated by the claim that bio-fuels contained little or no sulfur and or nitrogen. We wondered if a bio-fuel blend would yield results similar to that of low sulfur fuel oils.

We knew some studies were using a $20 \%$ blend of bio-fuel and fuel oil (B20). So for comparison purposes, we considered testing three blends; B10, B20 and B30. But upon reflection, we reconsidered opting to try $\mathrm{B} 15, \mathrm{~B} 30$ and $\mathrm{B} 45$. Our rational was the wider variant might yield more dramatic results. However, before mixing the three blends, we decided to try a small sampling of B45.

When we attempted to prepare a small sample blend, we encountered our first surprise. Our drum of bio-fuel had frozen up at room temperature $\left(60^{\circ} \mathrm{F}\right)$. After consulting with the distributor, we thawed the drum, mixed our B45 and attempted to fire the blend. Unfortunately, we were not able to clean up the fire and achieve a zero to a trace of smoke. After trying and successfully firing a B30 blend, we returned to our original plan to test B10, B20 and B30.

As discussed earlier, the fuel oil used to blend with this bio-fuel come from the same lot as was used for all other standard fuel oil testing. We were very careful to prevent the possibility of any 
cross contamination between the fuels. In addition to segregation and labeling, we dedicated a pump and set of oil lines for each fuel; see Appendix $\mathrm{C}$ for additional details.

All three (3) blends were fired in all test appliances and under all test conditions. In no case did we see any NOx reduction. However, of additional significance is the fact that we did not see any other operational or performance changes either. All three blends fired very much like standard fuel oil.

\section{IFGR (Induced Flue Gas Recirculation)}

Induced flue gas recirculation was one of the earliest techniques used by commercial industrial burner manufacturers to reduce emissions on large power gas burners. Several techniques were employed from induced (IFGR) to forced (FFGR) (fan assisted) to internally induced flue gas recirculation, all of which worked quite well. It is interesting to note that the internally induced flue gas recirculation method uses the same basic principals as was used by the old Blue Ray technology, the same as the Brookhaven FAB Burner and the same as is currently used by several European residential manufacturers today.

With an outside air intake boot installed on a Carlin EZ Burner, we connected the combustion air intake to the heat exchanger flue pipe. In that recirculation flue pipe, we installed a tee to allow the introduction of room air and two dampers to control the mix between room air and flue gas. The burner was run and various concentrations of flue gas and room air were tested; see Appendix D for additional details.

This type of system was more commonly used on commercial industrial power gas burners, and rarely if ever used on oil burners. One problem experienced with this type of system on commercial industrial burners was the propensity of the burner flame to become very unstable if the flue gas recirculation rate exceeded $12 \%$ to $15 \%$. None the less, using this type of system, commercial industrial gas burners could easily achieve sub 30 PPMVD NOx levels.

To our surprise, the EZ Burner did not experience this instability problem when subjected to high flue gas recirculation rates. Below is a recap of results at various rates of flue gas recirculation.

\begin{tabular}{|c|c|c|c|c|}
\hline FGR Rate & Interrupted & Constant & CO PPM & Reduction \\
\hline $5 \%$ & $131 \mathrm{PPM}$ & $135 \mathrm{PPM}$ & $0 \mathrm{PPM}$ & $18 \%$ \\
\hline $10 \%$ & $111 \mathrm{PPM}$ & $122 \mathrm{PPM}$ & $0 \mathrm{PPM}$ & $28 \%$ \\
\hline $15 \%$ & $96 \mathrm{PPM}$ & $101 \mathrm{PPM}$ & $0 \mathrm{PPM}$ & $40 \%$ \\
\hline $20 \%$ & $88 \mathrm{PPM}$ & $92 \mathrm{PPM}$ & $0 \mathrm{PPM}$ & $45 \%$ \\
\hline $30 \%$ & $58 \mathrm{PPM}$ & $69 \mathrm{PPM}$ & $6 \mathrm{PPM}$ & $60 \%$ \\
\hline $45 \%$ & $26 \mathrm{PPM}$ & $31 \mathrm{PPM}$ & $8 \mathrm{PPM}$ & $80 \%$ \\
\hline
\end{tabular}


In addition to the surprisingly good reduction in NOx emissions, in most cases the measured $\mathrm{CO}$ levels were zero. Only at the two (2) highest recirculation rates did we see any $\mathrm{CO}$ at all, albeit very nominal levels.

Two potential problems became immediately apparent though. The burner housing became unacceptably hot, especially at the highest FGR rates, and the flame began turning blue at anything over $10 \%$ FGR and was totally blue over $20 \%$ FGR rates.

None the less, this very inexpensive system could provide up to $80 \%$ NOx reduction with some design changes to address the two problems noted above. In addition, we could easily meet our targeted $10 \%$ to $15 \%$ emissions reduction using this method with as little as $5 \%$ FGR where temperatures would be much more tolerable (approximately $5^{\circ} \mathrm{F}$ to $10^{\circ} \mathrm{F}$ over ambient). In particular, high efficiency appliances where stack temperatures are lower, especially condensing furnaces, could benefit from this technique.

\section{Conclusion}

Clearly, there are a number of low cost, near no cost ways to reduce NOx emissions in residential oil burners, including:

- Low excess air. For virtually no cost, a well tuned burner, operating at low excess air levels, can reduce NOx emissions by $5 \%$ or more.

- Interrupted duty ignition. For a control upgrade of less than $\$ 5.00$ an estimated $10 \%$ NOx reduction can be achieved.

- Low sulfur oil (.05 by weight). For a few pennies a gallon, an estimated $10 \%$ NOx reduction can be achieved.

- Ultra-low sulfur oil (.005 by weight). For perhaps a few pennies a gallon more than low sulfur oil, an estimated $20 \%$ NOx reduction can be achieved.

- Flue gas recirculation. While some technical issues need to be addressed, for less than $\$ 50.00$ in material cost, a $20 \%$ reduction in NOx can be achieved.

And then there is the possibility of combining several of these strategies to achieve even higher NOx reduction levels. For example:

- A well tuned burner, operating at low excess air levels with an interrupted duty ignition control, firing ultra-low sulfur fuel oil, can on average reduce NOx emissions by $25 \%$ or more.

- The use of flue gas recirculation to cool the flame, whether that cooling flue gas be externally ducted from the flue pipe or recirculated within the burner flame zone, can reduce NOx emissions by $50 \%$ or more using today's standard 0.05 (.25) sulfur fuel oil. 
Unfortunately, no measurable benefit was evident from the other studied methods: reduced firing rates or bio-fuel blends. However, there may be other opportunities utilizing other techniques not explored here.

No one knows what, if any, NOx emissions reductions will be required of residential oil burning equipment in the future. However, as this study demonstrates, there are several options available to the industry to reduce residential oil burner NOx emissions should the need present itself in the future. 


\section{Appendix A}

\section{Test Equipment:}

Two combustion analyzers were used to collect data for this study. One for the field test data collection and a second for the lab test data collection. Both pieces of equipment were manufactured by Bacharach Instrument Company and were factory calibrated prior to the beginning of this test program. During the testing and data collection process, calibration was monitored and rechecked using calibrating span-gas.

\section{Lab Test Equipment:}

Lab test data was collected using a Bacharach Model ECA 450 Analyzer. The manufacturers specified tolerances are as follows:

$$
\begin{aligned}
\mathrm{O}_{2} \text { (oxygen) } \ldots \ldots \ldots \ldots \ldots \ldots \ldots \ldots \ldots & \pm 0.3 \% \text { (on flue gas) } \\
\mathrm{CO} \text { (carbon monoxide) } \ldots \ldots \ldots \ldots \ldots . & \pm 5 \% \text { of reading or } \pm 10 \mathrm{ppm}, \text { whichever is greater } \\
\mathrm{NO} \text { (nitric oxide) } \ldots \ldots \ldots \ldots \ldots \ldots \ldots . & \pm 5 \% \text { of reading or } \pm 5 \mathrm{ppm}, \text { whichever is greater } \\
\mathrm{NO}_{2} \text { (nitrogen dioxide) } \ldots \ldots \ldots \ldots \ldots . & \pm 5 \% \text { of reading or } \pm 10 \mathrm{ppm}, \text { whichever is greater } \\
\mathrm{Stack} \text { Temperature } \ldots \ldots \ldots \ldots \ldots \ldots \ldots & \pm 4 \% \text { between } 32^{\circ} \mathrm{F} \text { and } 255^{\circ} \mathrm{F} \\
& \pm 6 \% \text { between } 256^{\circ} \mathrm{F} \text { and } 480^{\circ} \mathrm{F} \\
& \pm 8 \% \text { between } 481^{\circ} \mathrm{F} \text { and } 752^{\circ} \mathrm{F} \\
\mathrm{SO}_{2} \text { (sulfur dioxide) } \ldots \ldots \ldots \ldots \ldots \ldots & \pm 5 \% \text { of reading or } \pm 10 \mathrm{ppm} \text { whichever is greater }
\end{aligned}
$$

\section{Field Test Equipment:}

Field test data was collected using a Bacharach Model PCA 65 Portable Analyzer. The manufacturers specified tolerances are as follows:

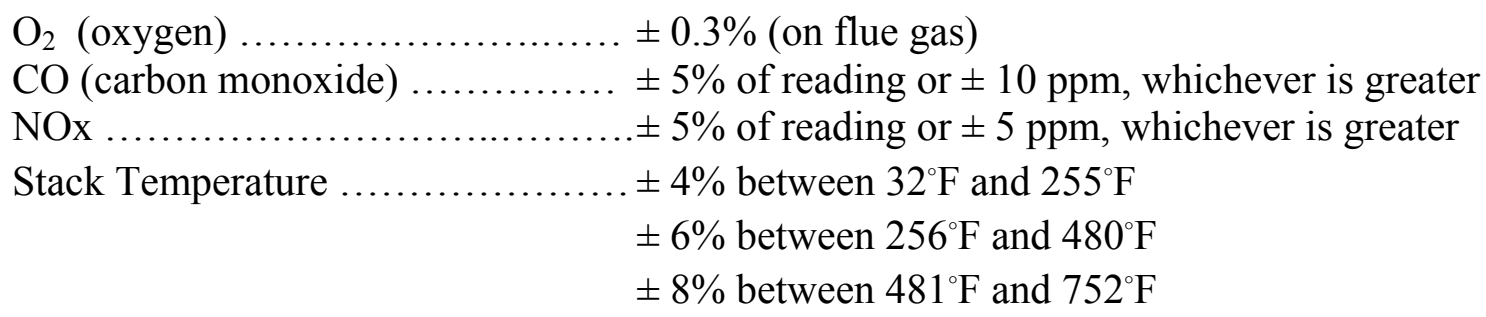




\section{Appendix B}

\section{Field Test Heat Exchangers:}

Field test data used in this report was taken from thirty-five (35) heat exchangers, including:

Fifteen (15) Cast Iron Sectional Boilers

Three (3) Steel Boilers

Thirteen (13) Warm Air Furnaces

Four (4) Oil Fired Hot Water Heaters

These heat exchangers were fired by one of seven (7) different burner brands, two (2) of which no longer produce burners.

Firing rates ranged from .50 to $1.25 \mathrm{GPH}$. Larger firing rates considered small commercial equipment were not included in the reported data.

\section{Lab Test Heat Exchangers:}

The Heat Exchangers used to collect data for the lab test portion of this study included:

One (1) Cast Iron Sectional Boiler

One (1) Horizontal Tube Steel Boiler

One (1) Warm Air Furnace

One (1) Direct Fired Hot Water Heater

All are current production models from manufacturers prominent within the industry and all four (4) included a combustion chamber. For this study, we did not test any heat exchangers without a chamber, but in reviewing the data on file for heat exchangers (cast iron sectional and steel boilers) without a chamber, NOx emissions levels were considerably lower, as was also the case for commercial-size equipment. 


\section{Appendix C}

Fuel Analysis

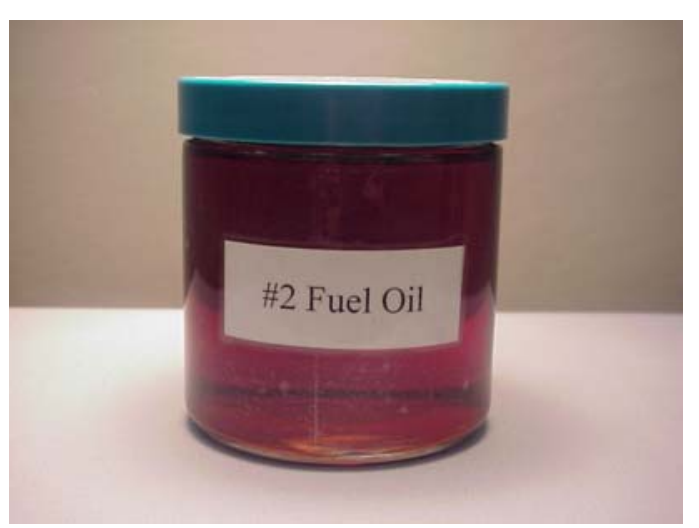

\section{No. 2 Fuel Oil Sample:}

\section{$\underline{\text { Result }}$}

Sulfur:

Nitrogen:

Carbon:

Hydrogen:

Oxygen:

$0.242 \%$
$170 \mathrm{ppm}$
$86.39 \%$
$13.50 \%$
$0.02 \%$

Method

D-4294

D-4629

D-5291

D-5291

D-5291

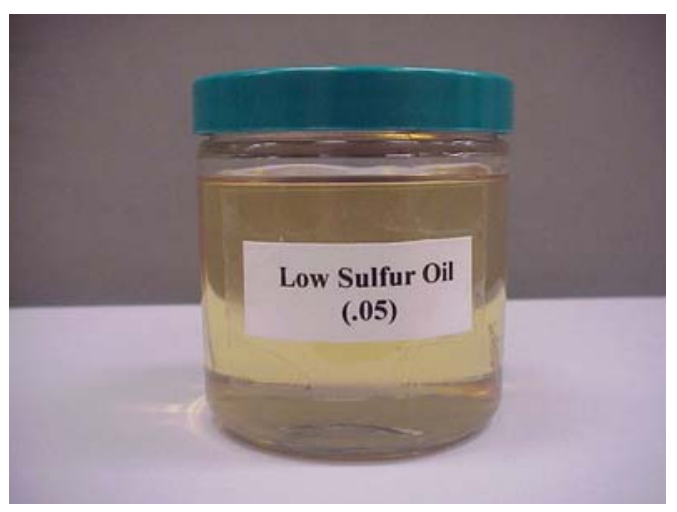

Low Sulfur Oil Sample (.05 by weight):

\section{$\underline{\text { Result }}$}

Sulfur: $\quad 0.0343 \%$

Nitrogen:

Carbon:

Hydrogen:

Oxygen:
$29 \mathrm{ppm}$

$86.47 \%$

$13.32 \%$

$0.02 \%$
Method

D-4294

D-4629

D-5291

D-5291

D-5291

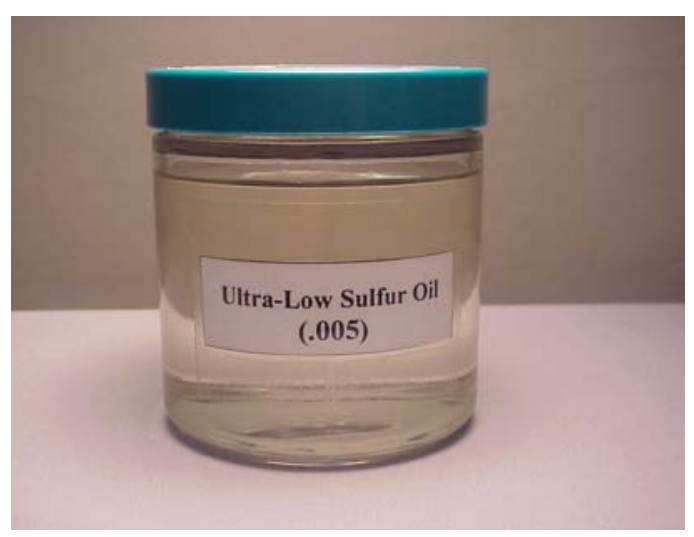

\section{Ultra-Low Sulfur Oil Sample} (.005 by weight):

\section{$\underline{\text { Result }}$}

Sulfur:

Nitrogen:

Carbon:

Hydrogen:

Oxygen:
$0.0049 \%$

4 ppm

$86.21 \%$

$13.69 \%$

$0.02 \%$ $\underline{\text { Method }}$

D-4294

D-4629

D-5291

D-5291

D-5291 


\section{Appendix C (Cont.)}

\section{Fuel Analysis}

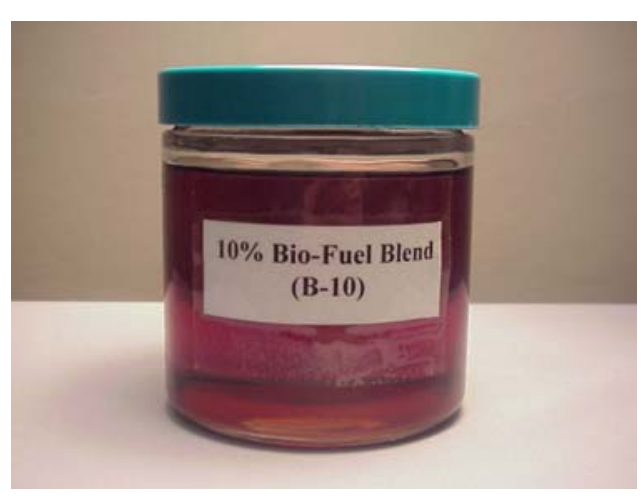

\section{0\% Bio-Fuel Blend Sample:}

$\begin{array}{lll} & \underline{\text { Result }} & \text { Method } \\ \text { Sulfur: } & 0.238 \% & \text { D-4294 } \\ \text { Nitrogen: } & 183 \mathrm{ppm} & \text { D-4629 } \\ \text { Carbon: } & 85.73 \% & \text { D-5291 } \\ \text { Hydrogen: } & 13.28 \% & \text { D-5291 } \\ \text { Oxygen: } & 0.02 \% & \text { D-5291 }\end{array}$

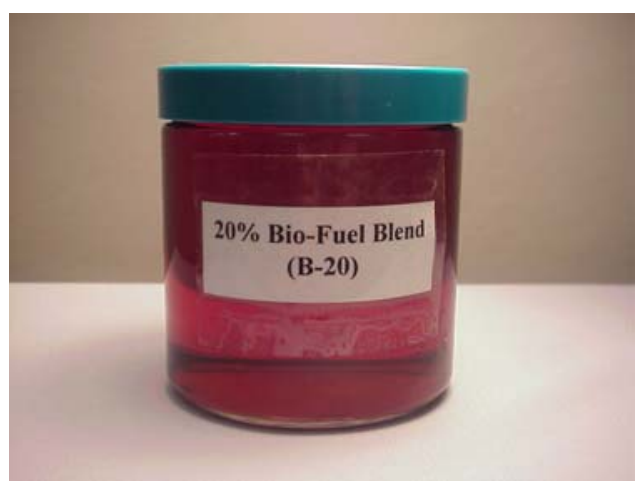

\section{0\% Bio-Fuel Blend Sample:}

$\begin{array}{lll} & \text { Result } & \text { Method } \\ \text { Sulfur: } & 0.218 \% & \text { D-4294 } \\ \text { Nitrogen: } & 183 \mathrm{ppm} & \text { D-4629 } \\ \text { Carbon: } & 84.41 \% & \text { D-5291 } \\ \text { Hydrogen: } & 12.97 \% & \text { D-5291 } \\ \text { Oxygen: } & \text { N/A } & \text { D-5291 }\end{array}$

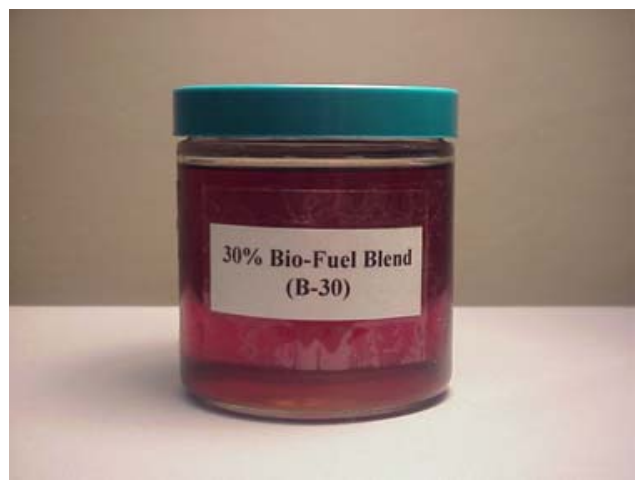

30\% Bio-Fuel Blend Sample:

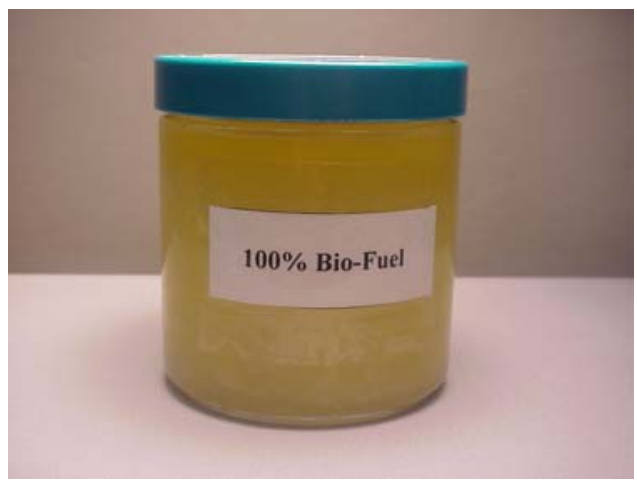

\section{0\% Bio-Fuel Sample:}

\section{$\underline{\text { Result }}$}

Sulfur:

Nitrogen:

Carbon:

Hydrogen:

Oxygen:

$5 \mathrm{ppm}$

$76.29 \%$

$12.25 \%$

N/A

\section{$\underline{\text { Result }}$}

$0.20 \%$

$177 \mathrm{ppm}$

$84.16 \%$

$13.15 \%$

N/A

$0.0076 \%$ $\underline{\text { Method }}$

D-4294

D-4629

D-5291

D-5291

D-5291

$\underline{\text { Method }}$

D-4294

D-4629

D-5291

D-5291

D-5291 


\section{Appendix D}

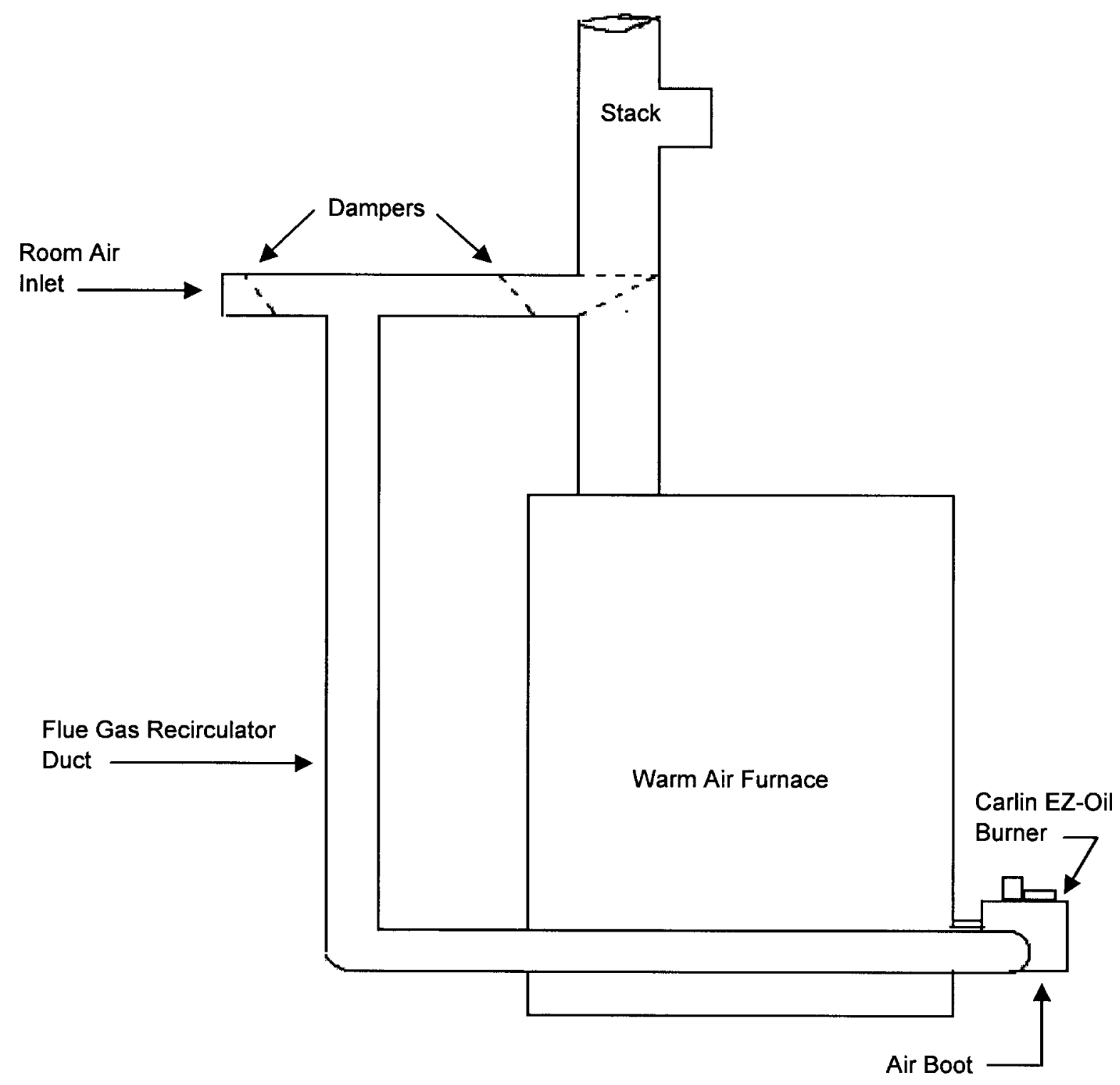


Paper No. 02-10

Factors Affecting Oil Burner NOx Emissions

Victor J. Turk, P.E.

R.W. Beckett Corp.

P.O. Box 1289

Elyria Ohio 44036

Phone: 440 353-6280

Fax: 440 353-6080

E-mail: vturk@beckettcorp.com

Internet: www.beckettcorp.com 


\section{Factors Affecting Oil Burner NOx Emissions}

Victor J. Turk, P.E., R.W. Beckett Corp.

\section{Abstract:}

A number of factors influencing oil combustion system performance have a significant effect on NOx emissions. These include burner design / operating parameters, appliance design / configuration and fuel type. Using a combination of experimental analysis and routine data gathering, these factors are compared, confirming the effects of three key precursors of high $\mathrm{NO}_{\mathrm{X}}$ formation - droplet flames, high flame temperatures and high fuel-bound nitrogen. Some typical performance levels are presented.

\section{Introduction}

Oil burner emissions include a number of chemical species that are the result of the combustion process. Although primary combustion product emissions (carbon dioxide) are of concern because of the long-range greenhouse effect, the more significant emissions involve the trace gasses that have a potentially more immediate effect on the environment. Oxides of sulfur are responsible for heat exchanger and flue corrosion, and these sulfur oxide particles have been identified as nucleation sites for certain particulate emissions. These emissions are directly related to fuel-borne sulfur, and are controlled by controlling fuel sulfur content. Carbon monoxide is a highly toxic inhalant, and has an acute and immediate effect on health at relatively low concentrations when it accumulates in the living space outside of the appliance exhaust system. These emissions are generally related to burner stoichiometry, and are controlled by proper set-up practice.

Additional significant emissions are the oxides of nitrogen, $\mathrm{NO}_{\mathrm{X}}$, that are precursors of ground-level ozone, the key component of smog. Although not currently regulated for residential oil burners in the primary North American market areas, this emission is receiving significant attention because of its potential environmental and economic impact. Control schemes for this pollutant are the focus of this paper.

\section{Factors influencing $\mathrm{NO}_{\mathrm{X}}$ emissions}

Oxides of nitrogen are formed almost exclusively in the combustion process. There are a series of reactions responsible for generating the $\mathrm{NO}_{\mathrm{X}}$, but the primary, rate-controlling reaction is the reaction between nitrogen gas $\left(\mathrm{N}_{2}\right)$ and dissociated oxygen $(\mathrm{O})$ to form nitric oxide $(\mathrm{NO})$ and dissociated nitrogen $(\mathrm{N})$, as in equation (1).

$$
\mathrm{N}_{2}+\mathrm{O} \leftrightarrow \mathrm{NO}+\mathrm{N}
$$

The rate for this reaction is a function of flame temperature, and increases as temperature increases. Other oxides of nitrogen form during the various stages of combustion by a complex series of reactions, and these are usually in lower concentrations.

Elevated $\mathrm{NO}_{\mathrm{X}}$ appears to be related to the presence of droplet flames (non-premixed diffusion flames) and higher flame temperatures. The larger fuel droplets can burn as individual "droplet flames" in which the fuel distills and burns at a stoichiometric ratio near one as it travels 
downstream in the flame zone. The closer the stoichiometric ratio is to one, the higher is the flame temperature, with its concomitant increase in NO formation.

Higher concentrations of nitrogen, and especially elemental nitrogen, in the flame contribute to the formation of $\mathrm{NO}_{\mathrm{X}}$, since an increase in reactants drives the reaction in the direction of the products of the reaction. The nitrogen present in combustion air at roughly $78 \%$ is a primary contributor, but nitrogen can be found in many fuels in a fuel-bound form, which also can contribute significantly toward the formation of $\mathrm{NO}_{\mathrm{X}}$.

Strategies that can reduce flame temperatures, avoid droplet flames in favor of premixed flames and minimize nitrogen are all useful in minimizing the formation of $\mathrm{NO}_{\mathrm{X}}$. These strategies are applied through burner design (flame temperature and droplet flame control), appliance design (flame temperature control) and fuel composition (nitrogen content). A number of experimental observations are presented that demonstrate these effects in the following discussion.

\section{Experimental considerations}

A variety of burners, appliances and fuels were used to evaluate the different strategies for reducing the formation of $\mathrm{NO}_{\mathrm{X}}$. Three burner designs, two wet-base cast iron boilers and two furnaces (all with different geometries and construction details) and several fuel compositions including petroleum fuels, bio-fuels and blends are described in Table 1.

Table 1 - Experimental Test Vehicles

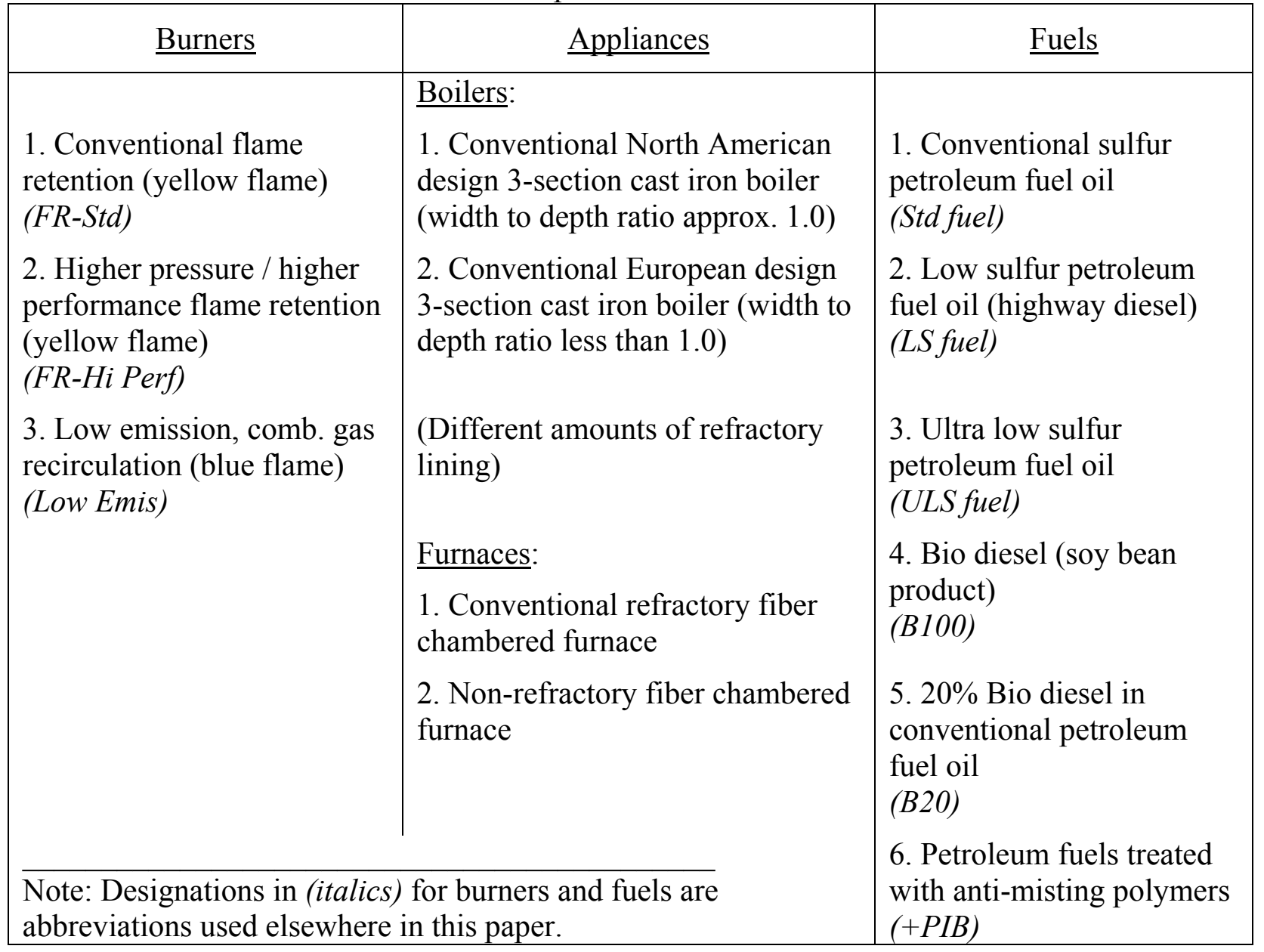


Combustion performance was measured as NO using an infra-red combustion gas analyzer. Measurements were taken at $3 \% \mathrm{O}_{2}\left(13.3 \% \mathrm{CO}_{2}\right.$ for petroleum based fuels) and NO results were converted to equivalent $\mathrm{NO}_{\mathrm{X}}$, assuming a ratio of $0.95 \mathrm{NO} / \mathrm{NO}_{\mathrm{X}}$. The appliances were operated at their recommended firing rates.

\section{Burner design factors}

Burners play a major role in reducing $\mathrm{NO}_{\mathrm{X}}$ because they control the dynamics of the combustion process and in doing so, minimize droplet flames in favor of premixed flames and control flame temperatures. Droplet flames can be minimized in several ways: by reducing droplet size and enhancing mixing (and therefore, approaching the premixed state); by increasing the relative velocity between the combustion air and the fuel droplets so that the flame is extinguished, allowing the droplet to vaporize more completely prior to combustion; and by reducing the available oxygen content around a droplet, effectively extinguishing the flame.

The three burner designs representing conventional flame retention, higher pressure / higher performance flame retention and low emissions flue gas recirculation were evaluated for $\mathrm{NO}_{\mathrm{X}}$ with a variety of fuels. The appliance for all tests was the North American style cast iron boiler with full refractory. In each case, $\mathrm{NO}_{\mathrm{X}}$ levels reported are compared to baseline conditions (conventional flame retention using standard fuel). These results are shown in Figure 1.

Burners that develop higher static pressures can be used to increase the effective mixing of fuel and air, and to the extent that they can generate higher velocities, extinguish droplet flames, which enhances fuel vaporization before combustion. The high performance flame retention burner show a $35-45 \%$ reduction in $\mathrm{NO}_{\mathrm{X}}$ levels compared to the standard burner, regardless of fuel. Higher static pressures also can be used to induce flue or combustion gas recirculation (FGR). Inducing these gasses into the combustion process helps to quench the combustion process, reducing flame temperatures, and reduces available oxygen, extinguishing droplet flames. Depending on the point

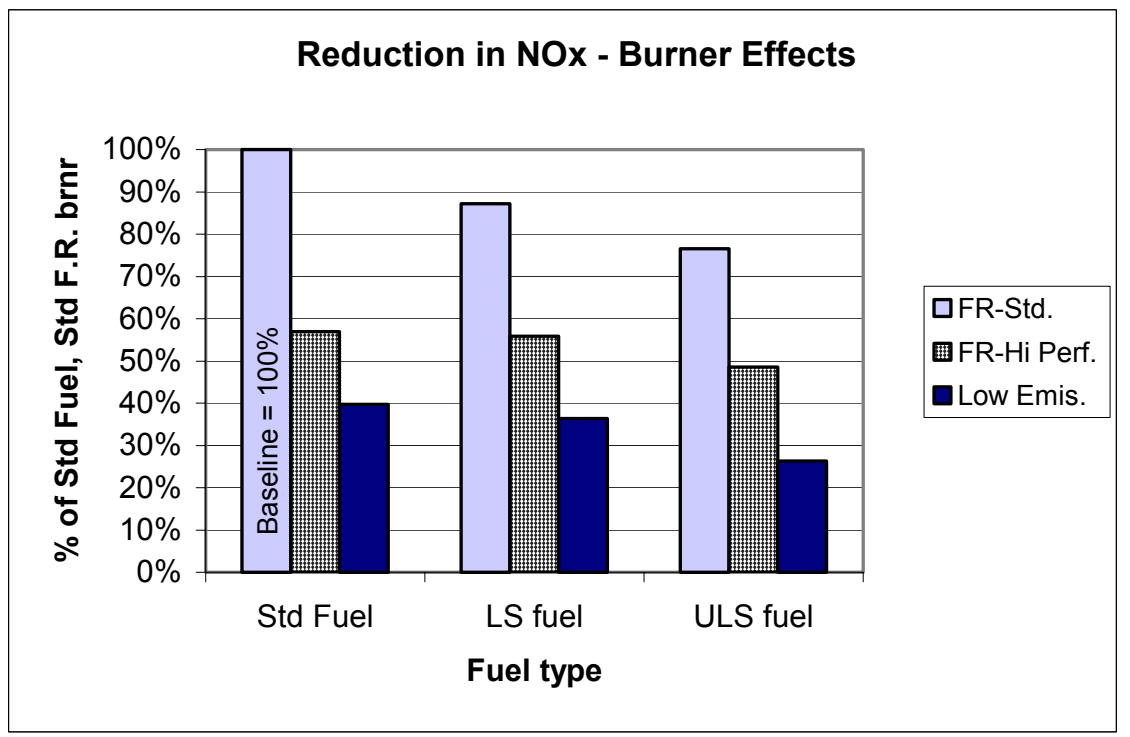

of introduction, the recirculated combustion gasses can help to vaporize the fuel droplets. The low emission burner showed a further 30$40 \%$ reduction in $\mathrm{NO}_{\mathrm{X}}$ levels compared to the high performance burner, showing these additional effects. Air atomization as an alternative to pressure atomization of fuel can be used to reduce droplet size, and can enhance mixing when air is introduced near the point of atomization.

Figure 1 - Burner effects on $\mathrm{NO}_{\mathrm{X}}$ emission. 


\section{Appliance design factors}

Both chamber shape and chamber refractory affect $\mathrm{NO}_{\mathrm{X}}$ formation in that they influence heat absorption and therefore flame temperature. "Cold" water-backed cast iron boiler chamber walls absorb heat from the flame, and reduce the temperature that can be maintained within the flame. Increased refractory reduces heat absorption and also reflects heat back into the flame, increasing the temperature that can be maintained within the flame. Longer, narrower flame paths alter the heat transfer conditions and appear to reduce the temperature that can be maintained within the flame.

The data in Figure 2 show these effects. The full refractory, North American style boiler was used as the base line, and reducing the amount of refractory in the chamber effected a reduction of $\mathrm{NO}_{\mathrm{X}}$ emissions. The modified chamber shape European boiler showed further reduction in $\mathrm{NO}_{\mathrm{X}}$ emissions. The low emission burner was used for this comparison because of its flexibility in readily firing a variety of chambers regardless of design.

Furnace chambers tend to operate at hotter temperatures since they are cooled by air that has a lower heat capacity. Many furnaces are designed with refractory chambers that further exacerbate this effect. However, furnaces can be successfully designed without refractory chambers and without this refractory to reflect heat back into the flame, observations show that these appliances perform similarly to cast iron boilers. These effects also are shown in Figure 2.

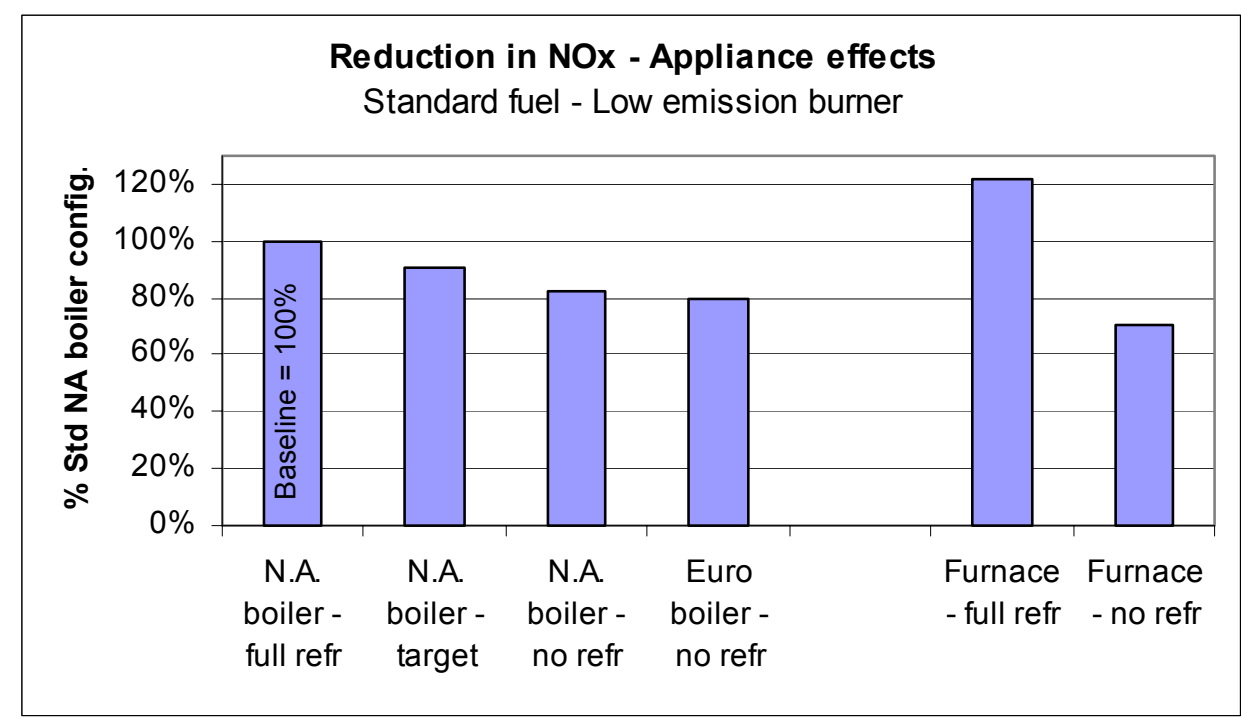

Figure 2 - Appliance effects on $\mathrm{NO}_{\mathrm{X}}$ emission.

\section{Fuel factors}

Fuel characteristics effect $\mathrm{NO}_{\mathrm{X}}$ formation primarily through the amount of nitrogen chemically bound in the fuel molecules. Fuel-bound nitrogen levels are determined by the fuel source and by the subsequent treatment that it receives. Other potential fuel effects can come from chemical additives that are designed to modify atomization characteristics or flame temperatures.

Petroleum-based fuels - All petroleum crude stocks contain varying small amounts of nonhydrocarbon materials or impurities, and the more important of these (at least from the emissions 
standpoint) are nitrogen- and sulfur-bearing compounds. Sulfur-bearing compounds have received more attention in recent years because of the potential emission improvements associated with their reduction in highway fuels (both middle distillate diesel fuels and light distillate gasolines). The hydro-treating processes that are used to reduce sulfur during refining also reduce nitrogen by a similar mechanism. Although the two reactions have different rates and the effects are independent because nitrogen and sulfur are present independent of each other in different refinery stocks, the general rule is that by reducing sulfur content the nitrogen content of the fuel is reduced as well. Typical sulfur and nitrogen contents in common petroleum-based fuels are shown in Table 2.

Table 2 - Typical Sulfur and Nitrogen contents in Petroleum Fuels

\begin{tabular}{|c|c|c|c|c|}
\hline (all values, ppm) & $\underline{\text { S-Nom }}$ & $\underline{\text { N-Nom }}$ & $\underline{\text { S-Range }}$ & $\underline{\text { N-Range }}$ \\
\hline $\begin{array}{c}\text { Ultra Low Sulfur } \\
\text { (Gr. 2-D diesel) }\end{array}$ & 10 & 4 & $<15$ & $<5$ \\
Jet-A & 870 & 15 & $<3000$ & $<20$ \\
$\begin{array}{c}\text { Kerosine } \\
\text { (Gr. 1-K) }\end{array}$ & 870 & 15 & $<300$ & $<20$ \\
$\begin{array}{c}\text { Hi-Way Diesel } \\
\text { Gr. 2-D low sulfur) }\end{array}$ & 360 & 150 & $<500$ & $100-200$ \\
$\begin{array}{c}\text { Off Road Diesel } \\
\text { (Gr. 2-D diesel) }\end{array}$ & 3260 & 350 & $2000-5000$ & $200-500$ \\
$\begin{array}{c}\text { Heating Oil } \\
\text { (Gr. 2 fuel oil) }\end{array}$ & 1700 & 650 & $1000-3000$ & $<900$ \\
\hline
\end{tabular}

Courtesy of Exxon-MobilCorporation

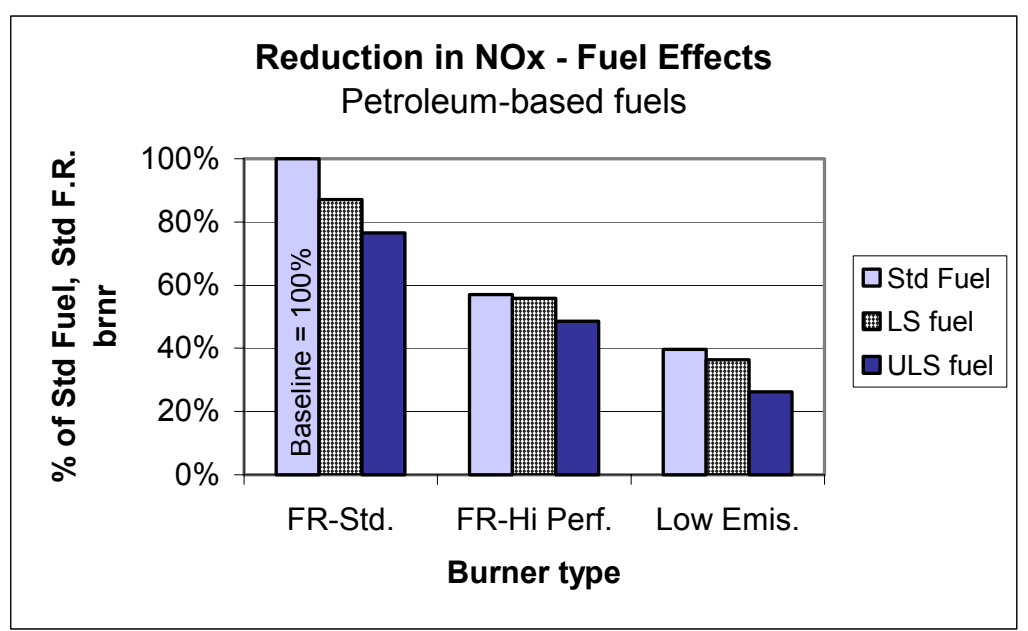

Figure 3 - Fuel sulfur effects on $\mathrm{NO}_{\mathrm{X}}$ formation
Reduced sulfur / nitrogen fuels were evaluated in all three burner designs, and showed important reductions in $\mathrm{NO}_{\mathrm{X}}$ formation. The reductions shown in Figure 3 show the cumulative effects of both fuel and burner effects. These fuelrelated reductions were similar from burner to burner, with the low sulfur fuel reducing $\mathrm{NO}_{\mathrm{X}} 5-10 \%$ compared to the standard fuel, and the ultra low sulfur fuel reducing $\mathrm{NO}_{\mathrm{X}}$ by 20-30\% compared to the standard fuel.

Bio-fuels - Bio fuels are inherently low in sulfur because of their biological source, but this does not necessarily predict that nitrogen will be low. Sources of this product are fairly diverse, and include vegetable oils, animal fats and reclaimed fats and oils. Since sulfur does not need to be stripped from bio-fuels, they are not subjected to the same processing as petroleum fuels, and do not receive 
this same opportunity for nitrogen reducing treatment. The higher heating value of this fuel is very similar to petroleum fuels, and flame temperatures are expected to be similar. A soybean-based biofuel was evaluated in both the neat (100\%) state and diluted to $20 \%$ bio-fuel in $80 \%$ standard fuel.

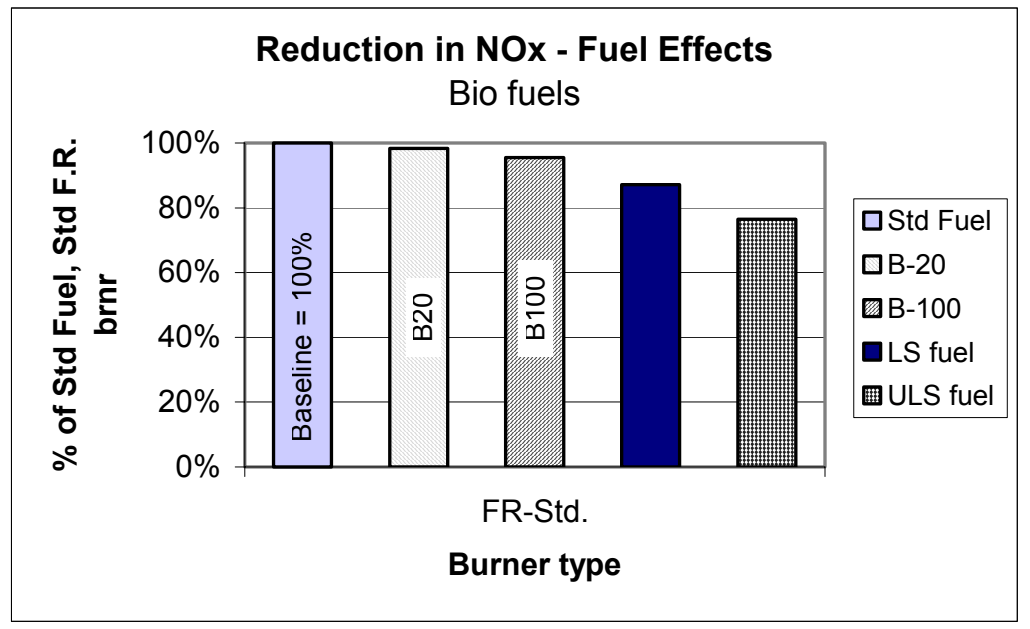

Bio-fuels were evaluated in all three burner designs, and showed only a minimal reduction in $\mathrm{NO}_{\mathrm{X}}$ formation with the two yellow flame burners, and a nominal reduction with the low emission burner. The results in Figure 4 show the results with the standard burner. Considering the fuel compositions and flame temperatures, these results are not unexpected.

Figure 4 - Bio-fuel effects on $\mathrm{NO}_{\mathrm{X}}$ formation

Additized fuels - Anti-misting additives that are usually added to aviation fuels to minimize misting (very fine particle production) during fuel tank damage can be added to burner fuels to control atomization. One additive, poly isobutylene (PIB), has been found to produce droplets with a smaller mean diameter and less variation in droplet size compared to the same fuel without the additive. The additive was used at a recommended dose of $10 \mathrm{ppm}$ to evaluate its effectiveness.

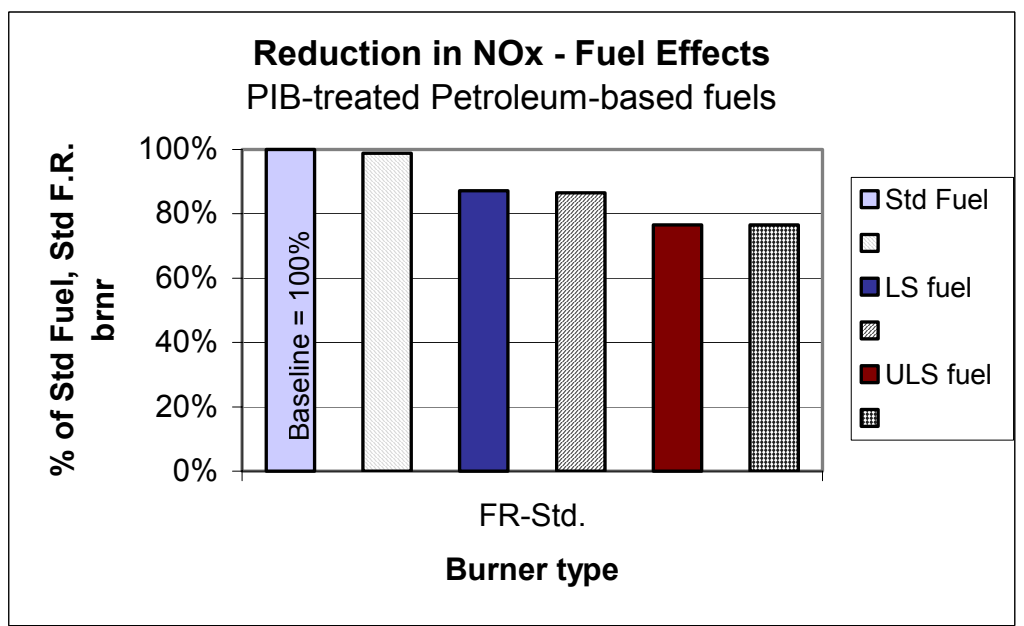

Figure 5 - Anti-misting additive effects on $\mathrm{NO}_{\mathrm{X}}$ formation
The PIB treated petroleum fuels (standard, low sulfur and ultra low sulfur) showed no significant change in $\mathrm{NO}_{\mathrm{X}}$ formation in any of the three burner designs. The results in Figure 5 show the results with the standard burner. The additive did not appear to make any significant changes in atomization. One possible explanation for this is because of the high degree of mechanical shear from the pump gear set may have cut the long chain PIB molecules.

\section{Conclusions}

Burner design, appliance design and fuel all play a role in $\mathrm{NO}_{\mathrm{X}}$ formation, and all can be controlled as strategies for reducing $\mathrm{NO}_{\mathrm{X}}$ emissions. The overall effectiveness of the various factors ranks as follows:

- Burner design provides the most significant reduction in $\mathrm{NO}_{\mathrm{X}}$ formation, with a potential of up to $60 \%$ reduction when a conventional flame retention burner is replaced with a low emission burner. 
- Appliance design can support an important reduction in $\mathrm{NO}_{\mathrm{X}}$ formation, with a potential of $20-40 \%$ reduction when conventional refractory lined chambers are replaced with cooler non-refractory lined chambers having shapes that are more conducive to low emission operation.

- Fuel composition can provide an important reduction in $\mathrm{NO}_{\mathrm{X}}$ formation, with a potential of $20-30 \%$ reduction when standard sulfur/nitrogen fuels are replaced with ultra low sulfur/nitrogen fuels.

\section{APPENDIX}

Table 3 - Selected properties of test fuels

\begin{tabular}{|c|c|c|c|c|}
\hline $\begin{array}{c}\text { Fuel } \\
\text { Designation }\end{array}$ & $\begin{array}{c}\mathrm{S} \\
(\mathrm{ppm})\end{array}$ & $\begin{array}{c}\mathrm{N}^{*} \\
(\mathrm{ppm})\end{array}$ & $\begin{array}{c}\text { Gravity } \\
(\mathrm{API})\end{array}$ & $\begin{array}{c}\text { Viscosity } \\
\left(\mathrm{mm}^{2} / \mathrm{s}\right)\end{array}$ \\
\hline Std fuel & 2120 & 960 & 34.4 & 2.3 \\
LS fuel & 250 & 840 & 33.9 & 2.1 \\
ULS fuel & 91 & 780 & 39.8 & 2.4 \\
B100 & $<100$ & 1400 & 29.0 & 2.8 \\
B20 & $2912 * *$ & 1050 & 32.9 & 2.6 \\
\hline
\end{tabular}

* Nitrogen contents are suspect (high), but are shown for reference, and to show relative levels.

** Dilution fuel (standard petroleum fuel oil) at $3395 \mathrm{ppm}$.

\section{REFERENCES}

The Ignition and Combustion of Drops in Sprays of No. 2 Heating Oil, B.J. Wood, W.A. Rosser, Jr. \& H. Wise, Stanford Research Inst., Menlo Park, CA. API Research Conf. On Distillate Fuel Combustion, paper CP63-7, 1963.

Soot Formation by Combustion of an Atomized Liquid Fuel, A. Sjogren, Combustion Institute, Pennsylvania State University. $14^{\text {th }}$ Symposium (International) on Combustion, 1972.

Nitrogen Oxides (NOx) and Oil Burners, T.A. Butcher, L.A. Fisher, B. Kamath, T. Kirchstetter \& J. Batey, Brookhaven National Laboratory, Upton, NY. Proceedings of the 1994 Oil Heat Technology Conference and Workshop, 1994.

Typical Sulfur and Nitrogen contents in Petroleum Fuels, Exxon-Mobil Corporation, 2002. 
Paper No. 02-11

The Autothermal Evaporation of Liquid Fuels by Using Cool Flames

Klaus Lucka, Heinrich Koehne Oel - Wärme - Institut gGmbH Kaiserstrasse 100 52134 Herzogenrath, Germany Phone: +49 (02407) 951816 Fax: +49 (02407) 951818

E-mail: k.lucka@owi-aachen.de Internet: www.owi-aachen.de 


\section{THE AUTOTHERMAL EVAPORATION OF LIQUID FUELS BY USING COOL FLAMES}

Klaus Lucka, Heinrich Koehne, Oel - Wärme - Institut gGmbH, Kaiserstr. 100, 52134 Herzogenrath, Germany

\section{ABSTRACT}

Modern mixture preparation systems for liquid fuels require a homogeneous fuel vapour air mixture. To make this possible a separation of the combustion- and mixing zone from the high temperature oxidation zone is necessary. Simultaneously the demand of a simple and inexpensive construction has to be fulfilled.

The use of cool flame reactions offers the opportunity to establish a technical vaporizing system for various fuels. Through such systems pre-mixing technologies can be applied for a number of liquid hydrocarbons such as FAME, nheptane, fatty acids and mixtures with IGO. The chemical reaction is investigated in a glass reactor that offers an optical approach and the possibility for temperature measurement in the reaction zone. Samples of the reaction gas can be taken and analysed by gas chromatography.

\section{INTRODUCTION}

In case of an oxidation of hydrocarbons the implementation of a premixing technology is favourable for different reasons. The quality of the fuel air mixture has a substantial influence on the development of products and pollutants. By means of separating the mixing zone from the oxidation process a selective creation of products can be achieved.

In the application of liquid fuels a simple technical execution of such systems exists in the injection of fuels into a preheated air flow. For a number of fuels this can be combined with the occurrence of exothermal reactions before the actual ignition. A significant feature of a set of liquid hydrocarbons is a temperature range where the conversion due to these reactions is decreasing with increasing temperature. This area is characterized as the negative temperature coefficient NTC [Bernard]. So called cool flames appear. These are combined with a partial oxidation of the fuel and a partial consumption of oxygen. A number of complex chemical chain reactions appear within the cool flames with the involvement of free radicals and a multitude of different intermediate products that show different life times. Stimulated aldehydes emit a weak blue light within the reaction [Lewis]. The cool flame reaction can be determined for a number of liquid hydrocarbons, especially representative pure chemicals have been studied. Also technical fuels such as industrial gas oil (IGO) and diesel as well as fuels from renewable energy sources e.g. rapeseed methyl ester (RME) show cool flames [Lucka99]. It was found that the initial and final temperatures of the fuels used are virtually identical. Apart from the initial temperature of RME, which is raised due to the boiling range of $330{ }^{\circ} \mathrm{C}$ to $340{ }^{\circ} \mathrm{C}$, all the temperatures lie within a narrow band. The dependency of the final temperature on the air ratio is negligible.

The heat released within the reaction makes an autothermal and at the same time residue free evaporation of the liquid fuels possible. Autoignition of the fuel air mixture can be securely avoided by the chemically restricted cool flames. Thus the apparent contradiction with liquid fuels can be handled which is that the temperature necessary for the complete evaporation of the fuel exceeds the theoretical ignition temperature. The key to the production of cool flames lies in the lack of stability of the links formed within the chain reactions as a result of oxygen being absorbed. That means that by achieving gas temperatures of approximately $480{ }^{\circ} \mathrm{C}$ further reactions of the mixture are limited. For this reason a reduction in the preheating of the air has only a very small effect on the final temperature of the cool flame.

The evaporation of fuels using cool flames enables the application of liquid fuels in the fields of application including the burner technology, fuel processors, the technique of turbines and engine technology.

\section{EXPERIMENTAL}

The investigations were carried out in a double-walled glass reactor. Thus an optical approach of the reaction was possible, which allowed a recording of the pale blue light of the reaction products. A photograph of the cool flame reaction could be taken with a ten minutes exposure time. The fuels RME, IGO a mixture of IGO and 5\% RME and the representative fuel $n$-heptane were sprayed into a preheated air flow by means of a simplex nozzle. A geared pump provided the necessary fuel pressure. The temperature of the gas flow was measured along the reactor axis. At the end of the $0.7 \mathrm{~m}$ long reactor samples of gas could be taken from the reaction and analysed by gas chromatography. 


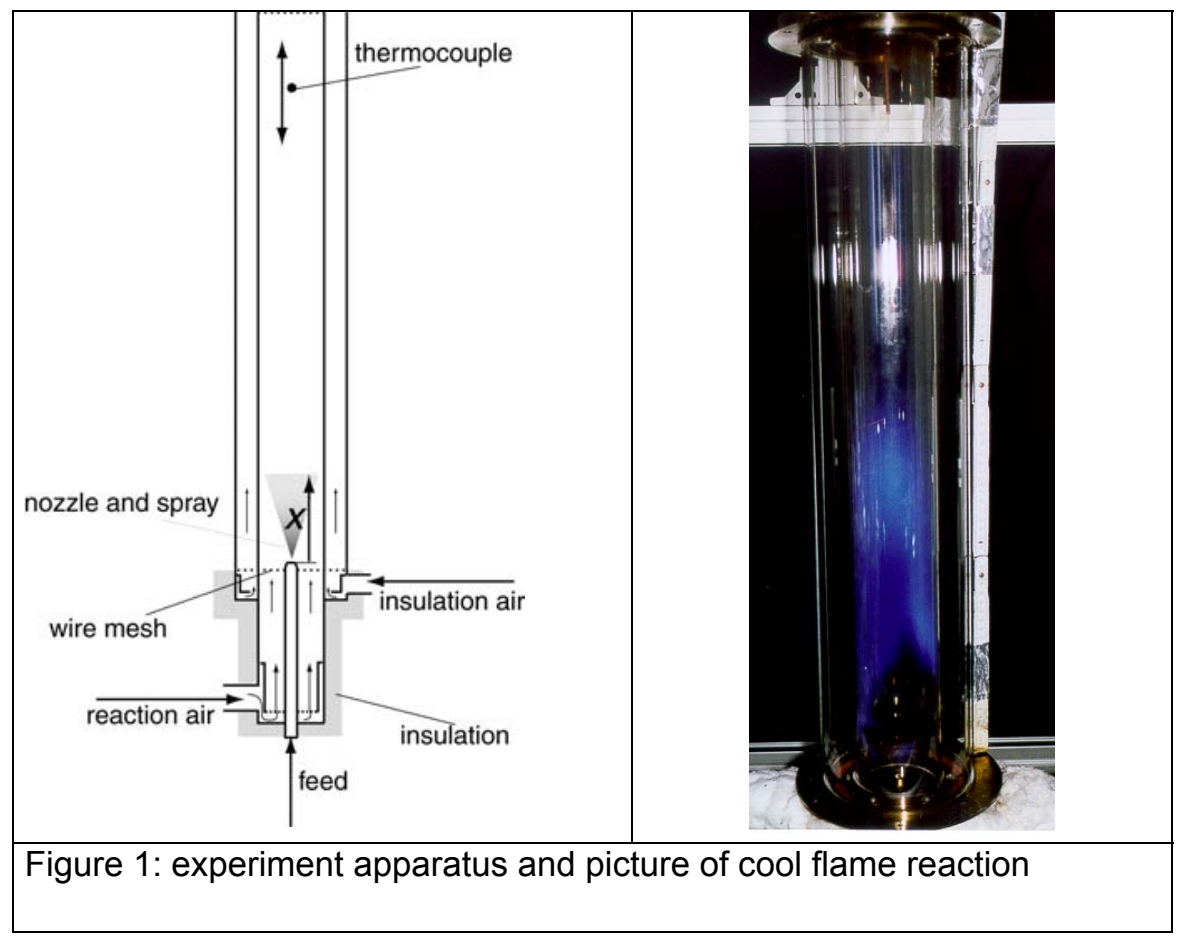

Besides the fuels the air inlet temperature and the air ratio were varied. The adjustment of the thermal boundary conditions was made by the regulation of the temperatures of the insulation and reaction air. Figure 1 shows the reactor design and an integral picture of the reaction zone of the cool flame reaction for IGO.

\section{RESULTS AND DISCUSSION}

\section{Regimes of exothermic pre reactions}

The fuel was injected either in air or in nitrogen to determine the different cool flame behavior. The injection into nitrogen was chosen to avoid oxidation reactions. The different temperature behaviors when fuel is injected into air or nitrogen give information about the heat release rate. The vertical axes always cover a temperature range of $200 \mathrm{~K}$. The horizontal axes cover an elapsed time of 800 seconds. Consequently, the different tests in Figure 2 could be compared directly to each other.

The axial temperature drop in the reactor when fuel is injected into hot nitrogen is nearly independent from the air inlet temperature. This was expected since oxidation reaction leading to a temperature increase in the reactor were avoided. A very different behavior is observed when the fuel is injected into hot air. At air inlet temperatures of about $310^{\circ} \mathrm{C}$ there was no difference between fuel injection in air or in nitrogen. This leads to the statement that below $310^{\circ} \mathrm{C}$ there are no exothermic pre-reactions in form of cool flames. There could be very weak exothermic pre-reaction called slow combustion but these reactions did not increase the temperature significantly. When fuel was injected into $350{ }^{\circ} \mathrm{C}$ hot air cool flame reactions were observed. The temperatures in the reactor increased up to $460{ }^{\circ} \mathrm{C}$ and stable conditions could be established. The amount of reaction rate and the related heat release from the cool flame changes significantly when the air inlet temperature is increased. Exothermic pre-reactions could even still be observed at air inlet temperatures of $550{ }^{\circ} \mathrm{C}$ with a reduced heat release.

The IGO/air mixture is heated while flowing along the reactor. Most of the fuel is heated and evaporated after $0,1 \mathrm{~m}$ to $0,15 \mathrm{~m}$. A completely different axial temperature distribution is recorded when the air inlet temperature was increased up to $359^{\circ} \mathrm{C}$ and cool flame chemistry took over. The IGO/air mixture temperature reached a steady state temperature of about $460^{\circ} \mathrm{C}$ which was due to the heat release from the cool flame. Since the air inlet temperature was below $470{ }^{\circ} \mathrm{C}$ the gradient $\Delta \mathrm{T} / \mathrm{dx}$ after the temperature drop is quite strong. The gradient gets weaker when the inlet temperature is higher than $470{ }^{\circ} \mathrm{C}$. This leads to the conclusion that the heat release is much stronger when the inlet temperature is below $470^{\circ} \mathrm{C}$. Higher temperatures are connected with a lower heat release rate of the pre-reactions. 

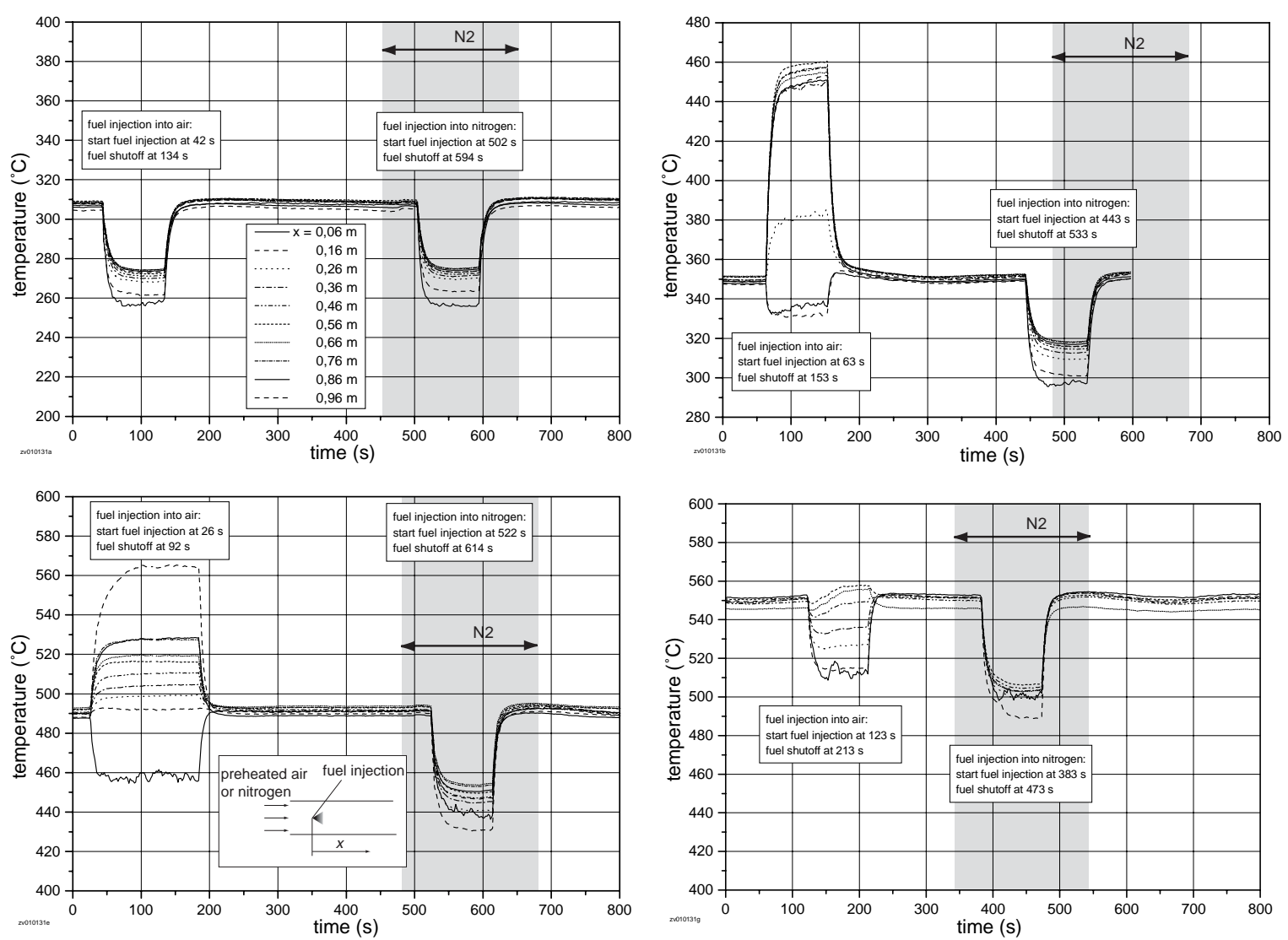

Figure 2: Axial temperatures versus time at different air inlet temperatures to determine the heat release rate of the cool flame, fuel injection into air and nitrogen, $P=8,7 \mathrm{~kW}, \lambda=1,27$

\section{The limit between autoignition and cool flames}

The temperatures before autoginition versus the axial distance from fuel injection are plotted in Figure 3 . Each temperature distribution was measured at different reactor lengths. To enable the measurement of different autoignition delay times the reactor length was reduced with increasing air inlet temperatures. The axial temperature

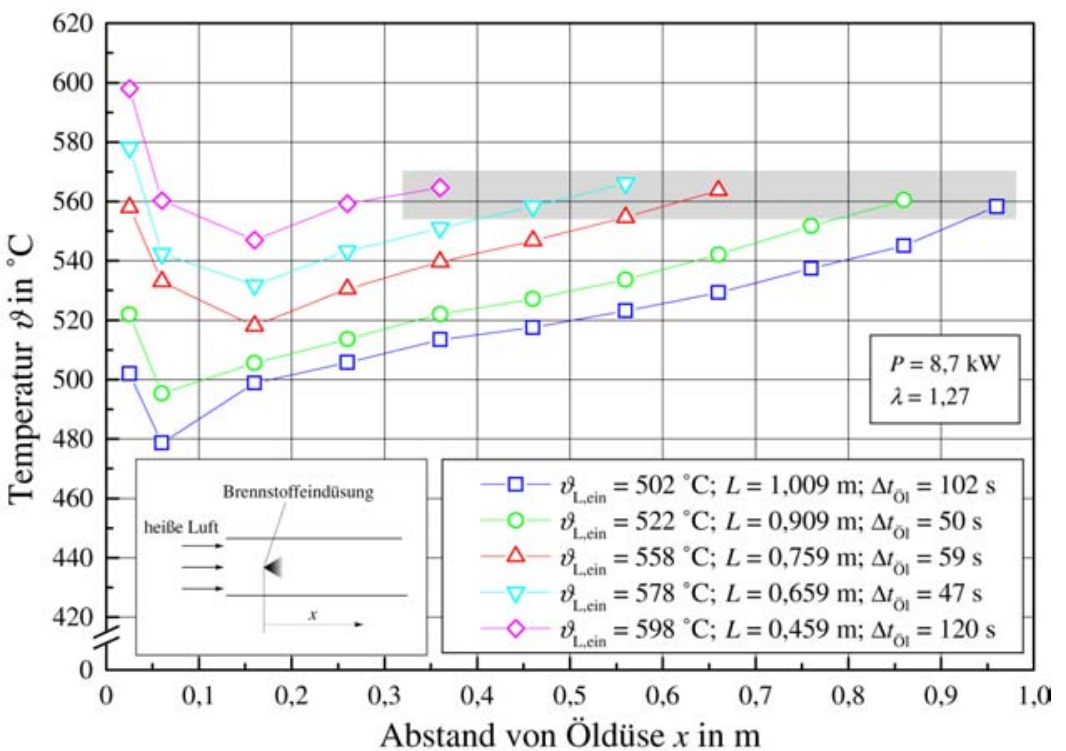

Figure 3: temperatures along the reactor at different air inlet temperatures before autoignition occurs at the end of the reactor [Steinbach] distribution at different air inlet temperatures was qualitatively always the same. After the temperature drop in the heating- and evaporation zone the temperature steadily increased to a temperature of about $560{ }^{\circ} \mathrm{C}-$ $570{ }^{\circ} \mathrm{C}$. It is interesting that always the same end gas temperature was reached before ignition took over. This result is in agreement with Westbrook [Westbrook] who showed that the ignition always occurs when a certain temperature is reached.

Even at higher air inlet temperatures than $570{ }^{\circ} \mathrm{C}$ with fuel injection running ignition was not observed instantly but after some seconds. This is because the mixture was cooled down under the critical ignition temperature due to the fuel heating and evaporation. An ignition in a system is likely when the temperature reaches $570{ }^{\circ} \mathrm{C}$ and free radicals are present. If the residence time is shorter than the autoignition delay time no ignition is expected. Figure 3 also shows that the duration of fuel injection until 
autoignition occurred could change significantly. The reaction rate of the cool flame and the combined heat release rate change with temperature. Therefore tests have been conducted at different air inlet temperatures. The air inlet temperature was kept so low that under the prevailing circumstances no ignition occurred. This led to nearly steady state conditions in the reactor.

\section{Thermal boundary conditions}

The requirements for initiation of the reaction were determined in the system by the variation of the thermal boundary conditions. The fuel was sprayed into the thermally conditioned reactor. The initiation of cool flames was determined by means of temperature measurement at the end of the reactor. If no reaction occurs, the gas temperature decreases

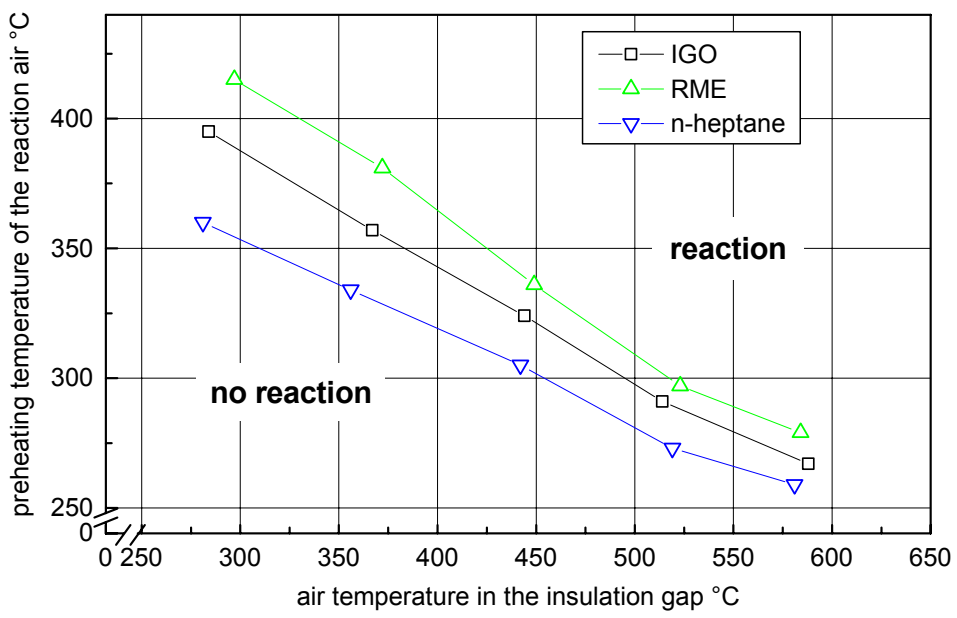

Figure 4: Initiation conditions for the cool flame reaction, different fuels are sprayed into a preheated air stream, $P=10 \mathrm{~kW}, \lambda=1.4$ [Mengel] due to the evaporation of the liquid. Raising the inlet temperature of the reaction air successively you reach the limit when an initiation can be observed detecting a temperature jump at the end of the reactor which is due to exothermal reactions. The limit divides the thermal boundary conditions of the system into an area of the cool flames and the area, within which no exothermal reactions are to be determined.

The beginning of cool flame reaction can not be assigned to characteristic temperature in this apparatus after figure 4. Rather the energy balance of the system is decisive. The reaction can be started up either with enthalpy transport through reaction air using high inlet temperatures in the reactor or through heat transfer to the reaction zone from the reactor walls.

With regard to the fuels the observed behaviour is rather comparable. N-heptane indicates the lowest starting up temperatures. The necessary temperatures increase around $15 \mathrm{~K}$ to $30 \mathrm{~K}$ for IGO which could be due to the high percentage of aromatic content of $28 \%$. Aromatic hydrocarbons tend to react at much higher temperatures than alcanes. Starting up the reaction for RME still on around $20 \mathrm{~K}$ higher temperatures are necessary which is due to the boiling range of 330 to $340{ }^{\circ} \mathrm{C}$. In case the thermal boundary conditions are chosen so that cool flame reactions occur in the respective area from figure 4 stationary temperature profiles establish, which were measured with the aid of the adjustable thermocouple.

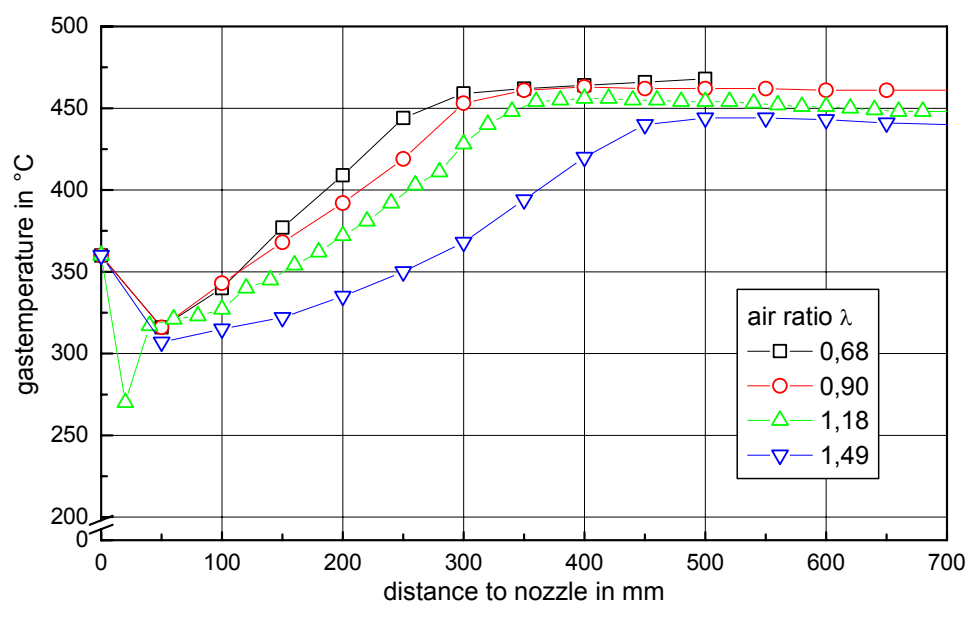

Figure 5: temperature distribution on the axis of the reactor as a function of the distance to the nozzle, fuel RME, $P=10 \mathrm{~kW}$.
Influence of the air ratio

Figure 5 presents the axial temperature profile for the injection of RME as a function of the distance from the fuel atomizer. The thermal output was $10 \mathrm{~kW}$. The air ratio was varied between 0,68 and 1,49 .

Close to the nozzle low temperatures are measured due to the evaporation of the liquid fuel. After that the temperature rises again due to mixture effects between fuel vapour and hot air. The starting of the cool flames is connected with a distinct temperature gradient, which ends apparently later at high air ratios. In this part of the gas flow the pale blue light of the reaction is visible as shown in figure 1. The final temperatures reach approximately $450^{\circ} \mathrm{C}$ almost independently on the air ratio. This originates in the chemical limitation of the reaction. Since the fuel conversion within the 
cool flame is in a first approximation proportional to the amount of air, more fuel conversion is to be determined with higher air ratios.

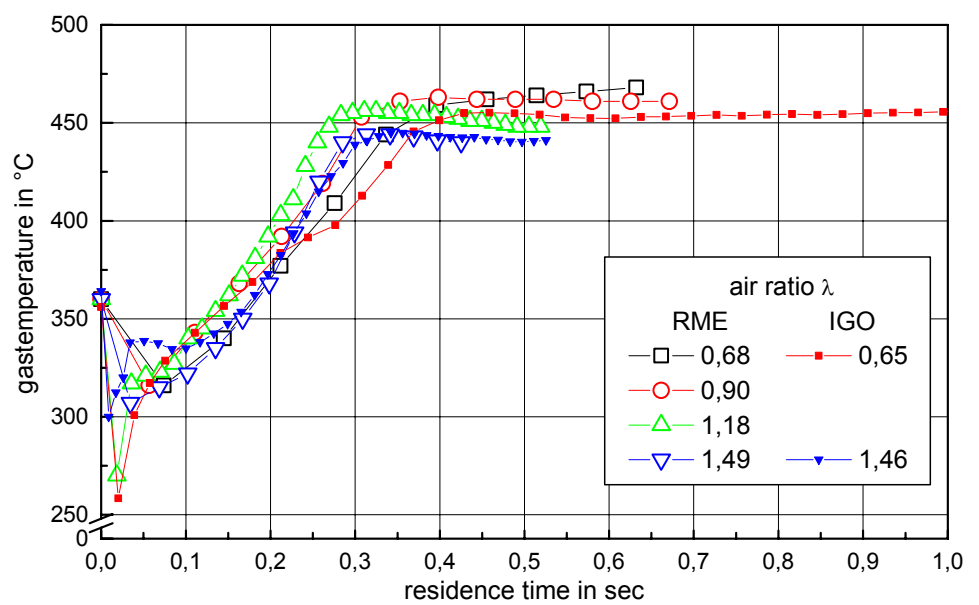

Figure 6: temperature distribution on the axis of the reactor as a function of the residence time, RME and IGO, $P=10 \mathrm{~kW}$

\section{Influence of the fuel type}

Figure 6 shows the appropriate temperature distribution as a function of the residence time. The conversion of the local temperatures into the temporal distribution was done using the local flow velocities. According to the figure the reaction of the cool flames starts independently of the air ratio after a time of approx. 0,15 seconds. This time represents the sum of the chemical and physical induction time, until the cool flames starts. The reaction is finished after a time of 0,3 to 0,5 seconds. These characteristic values are valid for any executed air ratio under the given thermal boundary conditions.

For comparative reasons some temperature distributions for the fuel IGO are included. The final temperatures of the reaction are slightly lower than that of RME. For this fuel the characteristic reaction times are comparable. The same is valid also for $n$-heptane, here the final temperatures however are approx. $20 \mathrm{~K}$ higher, and a mixture of IGO with 5\% RME which shows no significant difference to the behaviour of pure IGO.

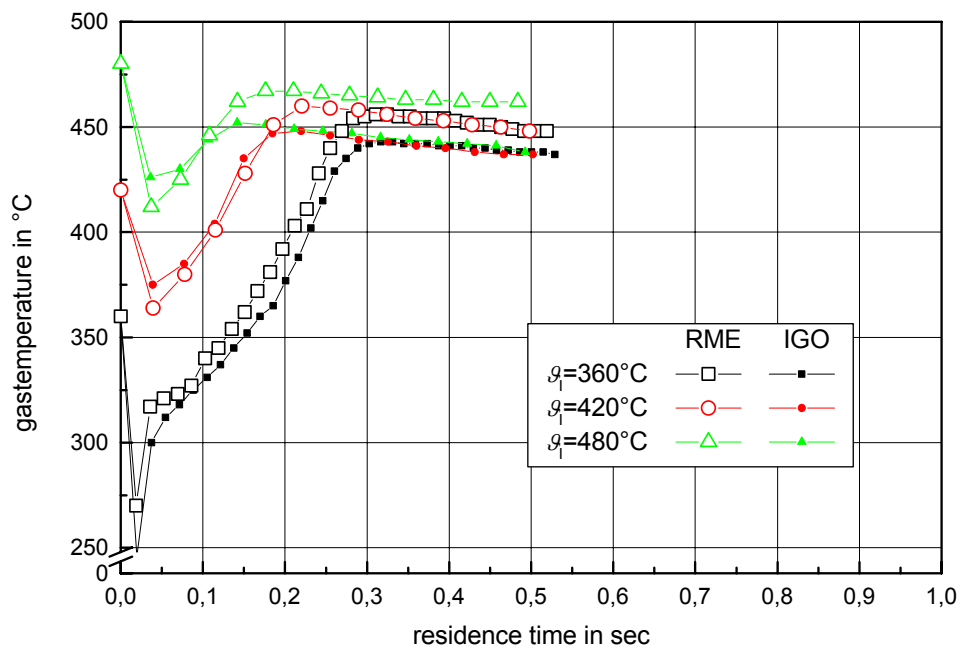

Figure 7: temperature distribution on the axis of the reactor as a function of residence time, RME and IGO, $p=10 \mathrm{~kW}$.

\section{Influence of the inlet temperature}

Figure 7 shows the temperature distribution for the injection of RME and IGO with different inlet temperatures. The processes are very much comparable for the fuels. Due to the chemical limitation the final temperature of the reaction

is not only independent of the air ratio but also of the inlet temperature and amounts in all cases around $450^{\circ} \mathrm{C}$. The cool flame reaction of RME reaches higher temperatures. The results show that the temperature rise within the cool flame reaction decreases with rising inlet temperature. The reaction time is decreasing with increasing inlet temperatures accordingly. Assuming that the temperature rise is proportional to the fuel conversion (same mass flows assumed), a reduction of the fuel conversion with rising temperature can be determined. This is the reason why the evaporator can be run safely without autoignition.

\section{Cool flame products}

The correlation between inlet temperature and conversion rate in the reaction can also be established analysing the gas chromatography studies of the reaction products. The surveyed RME consists to $87 \%$ of $\mathrm{C}_{18}$ fatty acids. In the reaction a molecular chain shortening and a partial oxidation take place, so that a set of different hydrocarbons can be detected in the gaseous phase of the reaction. These compounds are partially unstable. Besides a number of oxidation products are detected. 


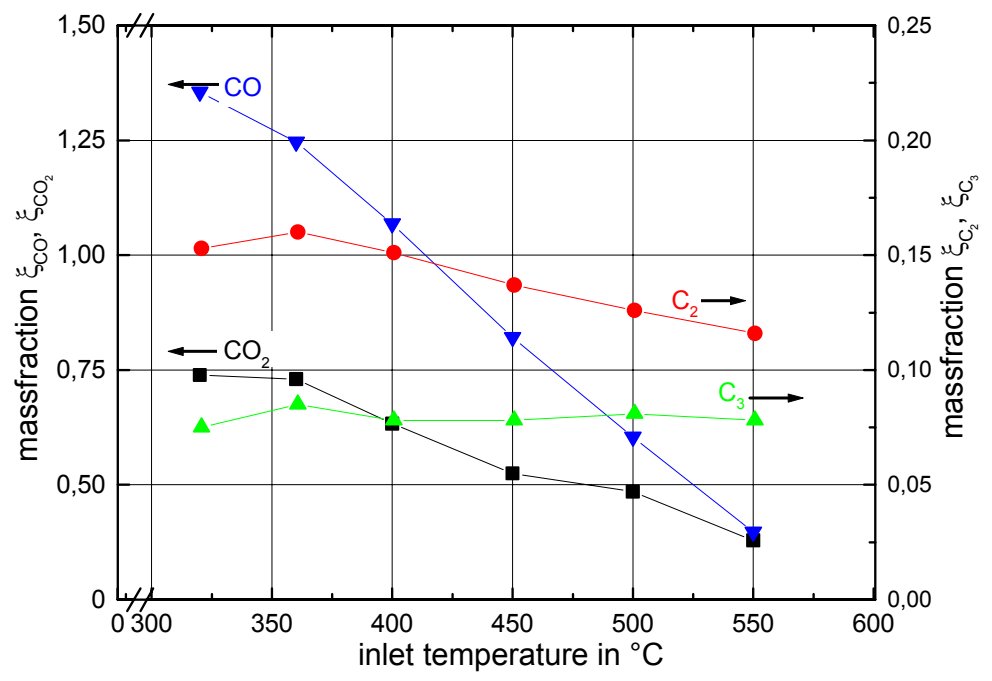

Figure 8 shows the analyses by gas chromatography by means of a heat conductivity detector, with which a limited number of species can be determined. Apart from small quantities of ethane and propane carbon monoxide, a maximum of 1.3 percentage, and carbon dioxide in larger proportions are found within the cool flame. The portion of these oxidation products decreases with rising inlet temperature; accordingly the remaining oxygen content increases. This pronounced NTC-behaviour can thus be proven also with the fuel RME.

Figure 8: Mass fraction of different reaction products, fuel RME, $P=$ $10 \mathrm{~kW}, \lambda=1.2$

\section{Energy conversion in cool flames}

After the cool flame is initialised the system runs without additional external heat. Equally the reaction conversion rises with a decrease in the heat supply (Fig. 9). Approximately eight percent of the heating value is converted in the cool flames to evaporate the hydrocarbons and to pre-heat the oil-air-mixture in sub-stoichiometric operation points when no air pre-heating is included. As a result of oxidation and decay reactions, it is mainly long hydrocarbon chains that react to form short molecules during this process. A conversion into carbon monoxide and carbon dioxide can be verified in the cool flame product.

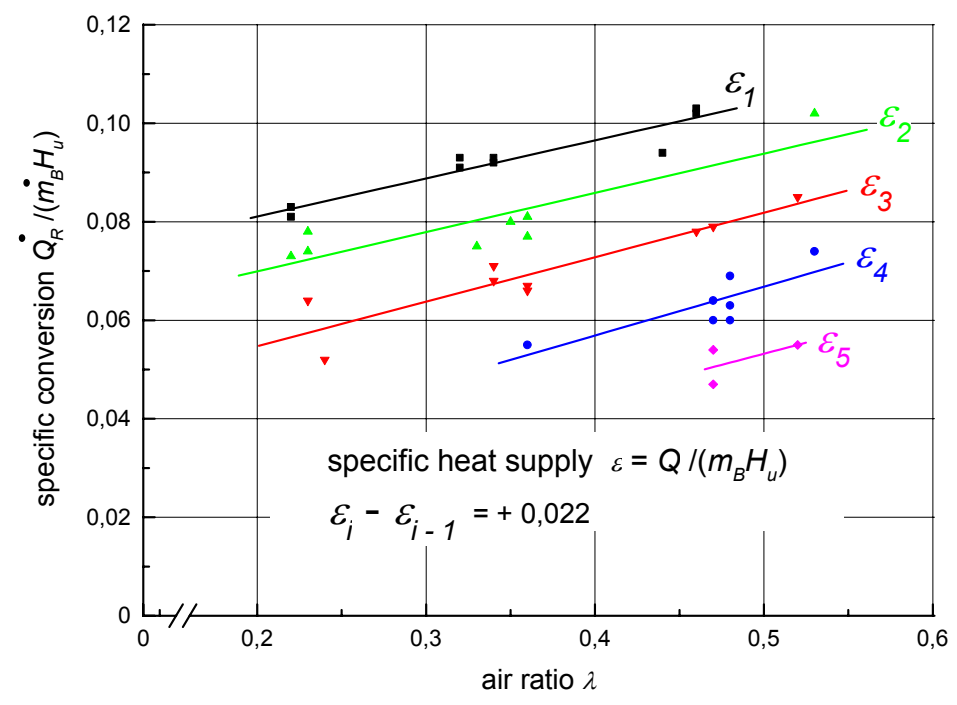

Figure 9: Reaction conversion in the cool flame as a function of the air ratio and the specific heat supply; IGO, $P=5 \mathrm{~kW}$

\section{EXAMPLES FOR APPLICATIONS}

\section{Reformer Design}

The Oel-Wärme-Institut (OWI) has developed a fuel processor to produce fuel cell suitable gases by using industrial gas oil, diesel or gasoline as well as renewable fuels. The fuel processor consists of two reaction chambers which are thermally decoupled as well as isolated to prevent flash back. The design of the fuel processor is shown in Fig. 9. In the first stage the liquid fuel is mixed and evaporated with the combustion air necessary for the process. The heat required for the evaporation is produced autothermically by pre-reactions of the fuel/air mixture in the form of a cool flame. This phenomenon features a complete and residue-free evaporation of liquid hydrocarbon mixtures. Autoignition does not result even after long residence times as the characteristics of the reaction kinetics inhibit this. The initialisation of the cool flame reactions takes place when the hydrocarbon is atomised in the preheated air stream with $\vartheta \sim 310^{\circ} \mathrm{C}$. Therefore an air pre-heater is provided in the set-up. The heat needed to actuate the pre-reaction can also be produced with a start-up burner. After initialisation air pre-heating is not mandatory since the internal heat management of the evaporator holds the reaction zone steady. By using cool flame for the evaporation the demand on 
the oil-spray quality is less than in conventional systems. Therefore low firing rates are achievable with commercially available atomising systems.

The produced homogeneous fuel/air mixture at a temperature of about $420^{\circ} \mathrm{C}$ is transferred to the second stage of the fuel processor by catalytic partial oxidation (CPO) below $1000{ }^{\circ} \mathrm{C}$. The measured temperatures are shown in Fig. 10 with respect to time. The system is sensitive on variations of the air ratio. After $15 \mathrm{~h}$ on stream the air ratio has been reduced from $\lambda=0.38$ to 0.36 . Thus the temperatures in the catalyst are reduced by $80 \mathrm{~K}$ whereas the temperatures in the cool flames keep steady.

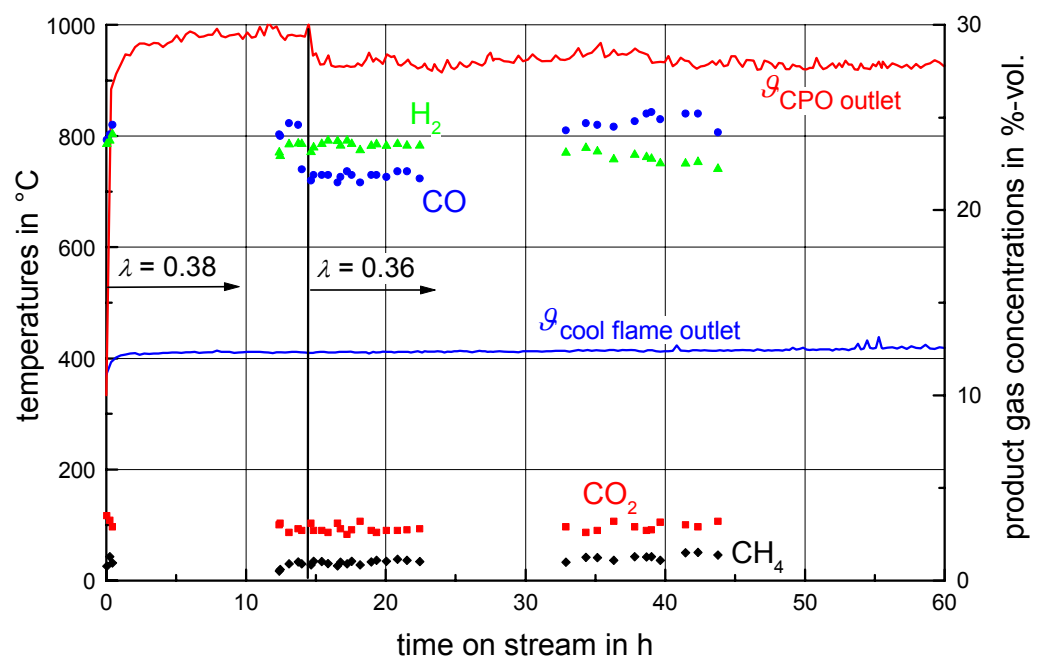

Figure 10: Measured product gas concentrations and temperatures in the fuel processor with respect to the time on stream $(\lambda=0.38$ $0.36, P=5.5 \mathrm{~kW}$, fuel sulfur content $\xi_{s}=10 \mathrm{ppm}$ ) [Hartmann]

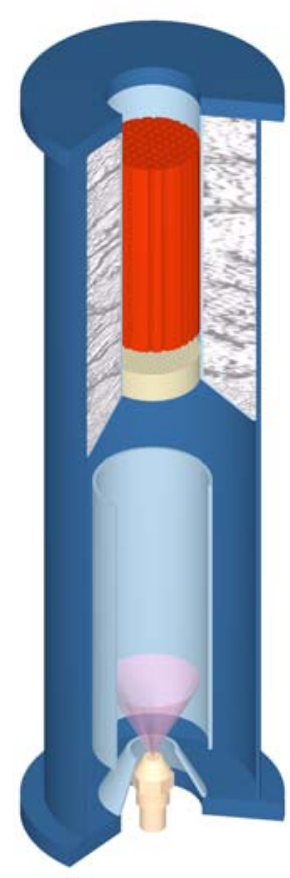

The conversion of hydrocarbons is very good. The concentrations of carbon monoxide and hydrogen reach $23 \%$ to 24 $\%$ and are close to the equilibrium concentration. Caused by the high catalyst temperatures the overall hydrocarbon concentration is lower than $1.5 \%$. The formation of acetylene as a soot precursor can be neglected so that the formation of soot is avoided. Soot formation has not been detected in the evaporator or the catalyst. Carbon deposits have been found in the outlet tube which connects the fuel processor to the off gas burner. In this region where the temperature is significantly below $800{ }^{\circ} \mathrm{C}$ the conditions for the Boudouard and heterogeneous water gas reaction are favoured.

\section{Burner concept with cool flames - The porous burner}

Combustion in porous, inert media offers exceptional advantages compared to techniques of free flame burners. The relatively new technology of porous medium burners is characterized by higher burning rates, increased flame stability with low noise emissions and lower combustion zone temperatures which lead to a reduction in $\mathrm{NO}_{\mathrm{x}}$ formation. Porous medium burners also show low emissions of $\mathrm{CO}$ and very small scale sizes. Additionally, complex combustion chamber geometries, which are not feasible with conventional state of the art combustion techniques, are possible.

A novel combustion technique based on the combustion in porous media has been developed in the last years at the Department of Fluid Mechanics at the University of Erlangen. The major novelty of this work is the combustion stabilization principle, which allows an extremely stable operation of the premixed combustion process in the porous matrix. The flame stabilization layer is placed inside of the porous matrix and is well defined by the matrix design. The most important criterion which determines whether or not a combustion process can take place inside a porous structure is its critical pore size. If the size of the pores is smaller than this critical dimension, flame propagation is prohibited; the flame is always quenched. On the other hand, if the pore size exceeds the critical dimension, flame propagation inside the porous structure is possible. In the porous burner, the combustion process is stabilized with a sudden change of the pore size.

A porous burner for liquid fuels like IGO should be operated with a clear separation between the combustion and the evaporation process. The oil porous burner combines the concept of the cool flame vaporizer developed at OWI with 
the porous burner concept developed at LSTM-Erlangen. The result is a high power modulating oil burner with low exhaust gas and acoustic emissions, operating with a condensing heat exchanger and thus allowing an efficiency improvement by $10 \%$. Figure 11 shows the concept of the porous burner Unit and the emissions during power modulation.

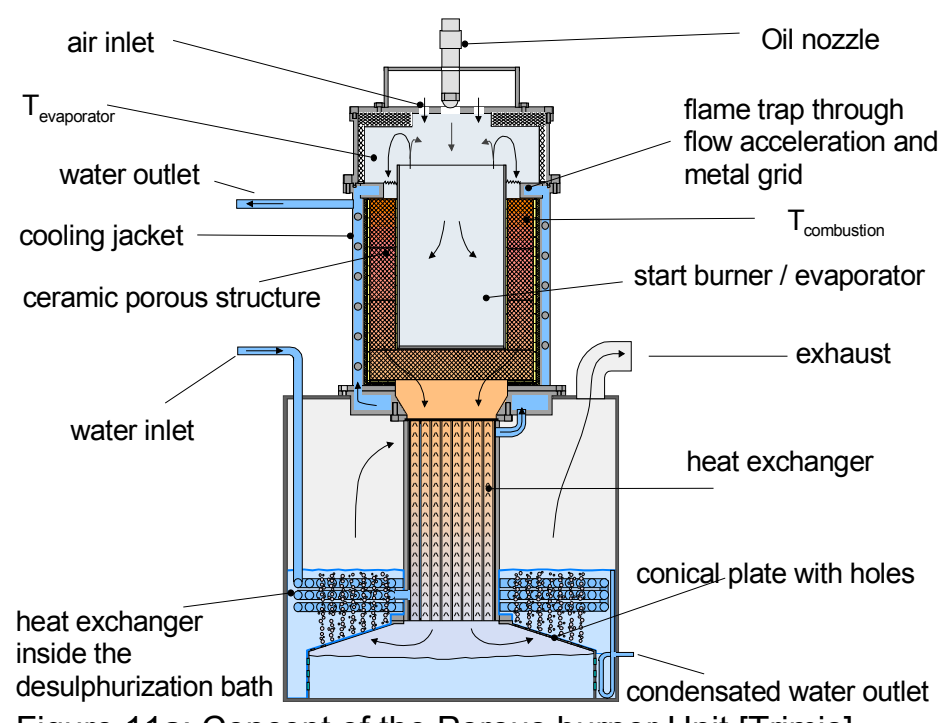

Figure 11a: Concept of the Porous burner Unit [Trimis]

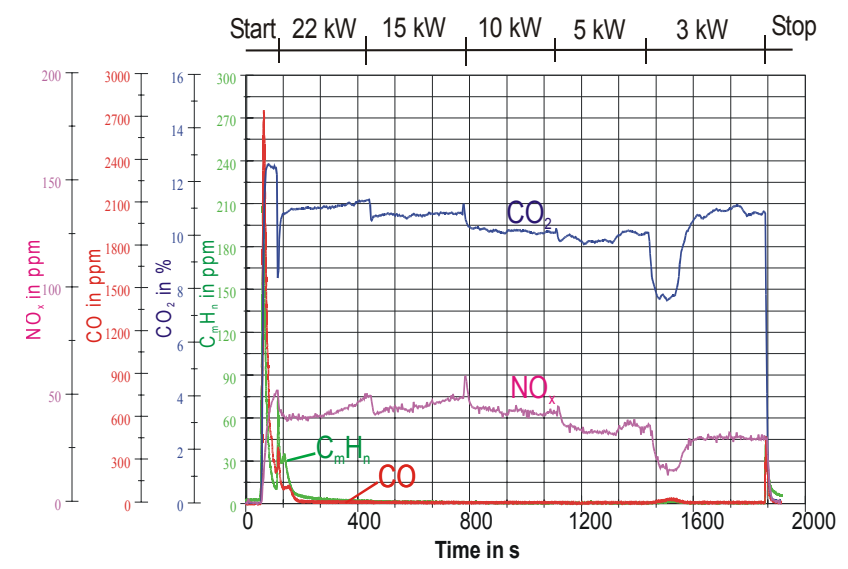

Figure 11b: Transient emissions during modulation

\section{REFERENCES}

Griffiths, J. F.; Barnard, J. A., Flame and Combustion. Third Edition, Glasgow: Blackie Academic \& Professional, 1995, ISBN 0-7514-0199-4.

Lewis, B; von Elbe, G., Combustion, Flames and Explosions of Gases. Third Edition, London: Academic Press Inc., ISBN 0-12-446751-2.

Westbrook, C. K., Chemical Kinetics of Hydrocarbon Ignition in Practical Combustion Systems, 28th Symposium on Combustion, Vol. 28, 2000.

Steinbach, N; Lucka, K. and Köhne H. Investigation of the ignition phenomena and the autoignition delay time of IGO/air mixture in a continuous flow reactor at atmospheric pressure, Sixth International Conference on Technologies an Combustion for a Clean Environment, Portugal, 9.-12.7.2001.

Lucka, K. and Köhne, H., Usage of Cold Flames for the Evaporation of liquid Fuels, Fifth Conference on Technologies and Combustion for a Clean Environment, Lissabon, 1999.

Gitzinger, H.P., Nutzung Kalter Flammen für die Gemischbildung zur Realisierung eines Strahlungsbrenners für flüssige Brennstoffe, PhD thesis, ISBN: 3-8265-4937-6, RWTH Aachen, 1999.

D. Trimis, K. Wawrzinek, O. Hatzfeld, K. Lucka, A. Rutsche, F. Haase, K. Krüger, C. Küchen, A novel porous burner for liquid fuels based on porous media combustion and cool flame vaporization, combustion and the environment, $24^{\text {th }}$ Event of the Italian Section of Combustion Institute, 16.-19. September 2001, ISBN 88-88104-01-1.

K. Lucka, N. Steinbach, C. Mengel, H. Köhne, Autotherme Verdampfung als Vorraussetzung für Vormischtechniken von flüssigen Brennstoffen, VDI-TGA Fachtagung, Brenner in der Heiztechnik, 31.1.2002, Hannover.

C. Mengel, L. Hartmann, H. Köhne, K. Lucka, Multi-fuel reformer for SOFC technologies in stationary and automotive applications, World Renewable Energy Congress VI, 29.6.-5.7.2002, Köln.

L. Hartmann, K. Lucka, C. Mengel, H. Köhne, POX-Reformer for Gas Oil / Diesel in Stationary and Automotive SOFC Technologies, $5^{\text {th }}$ European Solid Oxide Fuel Cell Forum, 1.-5. Juli 2002, Luzern, Schweiz. 
Paper No. 02-12

Results of the Flame Quality Monitor Field Test Program

Henry E. Troost, PE, Honeywell International, Dr. Thomas Butcher, Brookhaven National Laboratory, \& Andrew M. Rudin, Insight Technologies, Inc.

Henry E. Troost, PE, Honeywell International 1985 Douglas Dr. N.

Golden Valley, MN 55422

Phone: 763-954-6581

Fax: 763-954-4003

E-mail: henry.troost@honeywell.com

Dr. Thomas Butcher, Brookhaven National Laboratory

12 North Sixth St., Bldg. 526

Upton, NY 11973-5000

Phone: 631-344-7916

Fax: 631-344-2359

E-mail: butcher@bnl.gov

Andrew M. Rudin, Insight Technologies, Inc.

1150 Walnut Ave.

Bohemia, NY 11716

Phone: 631-261-6940

Fax: 631-262-7840

E-mail: arudin@insighttechnologies.net

This presentation was prepared with the support of the U.S. Department of Energy, under Award No. DE-FC26-00NT40994. However, any opinions, findings, conclusions, or recommendations expressed herein are those of the author(s) and do not necessarily reflect the views of the DOE. 
Results of the Flame Quality Monitor Field Test Program

T. Butcher, Alex Mistretta, Yusuf Celebi, and George Wei, BNL; Henry Troost, Honeywell; and A. Rudin, Insight Technologies

\section{Introduction}

The Flame Quality Indicator (FQI) concept was conceived as a low cost technique to monitor an oil burner flame and inform a service organization when attention is required. The aim of the FQI concept was to reduce no-heat calls, unscheduled service calls, soot problems and extend the interval between heat exchanger cleanings. This paper reports on a two-year field test that is near completion, of a commercial product based on this concept; the Honeywell Flame Quality Monitor (FQM). The test program included another commercial form of this concept - the Advanced Flame Quality Indicator (AFQI) developed by Insight Technologies. The objective of this field test has been to evaluate the effectiveness of this concept under real field conditions and to quantify the benefits. Technical background on the development of this concept and an introduction to the field test have been provided in earlier papers and reports ${ }^{1,2,3}$.

The FQI concept employs a cad cell in an oil burner to measure the brightness of the flame after a fixed warmup period. The flame brightness is measured at every burner cycle and compared with a "setpoint" that was established when the burner was last serviced and correctly tuned. If the flame brightness deviates from the setpoint by more than a preset amount, the burner is considered to be "out-of-range" and should be serviced.

The Honeywell Flame Quality Monitor is a small electronic device that works in combination with the Honeywell R7184, microprocessor-based, burner primary control. The FQM can be mounted on the jacket of a boiler or furnace and connected, via a small modular cable, to the data port on the R7184. The FQM gets the flame brightness signal and also power from the oil burner primary control. The FQM display panel has a "calibrate" button that is used by the service technician to establish the initial setpoint. There is also a set of LEDs that indicate the burner condition. If a burner is out-of-range, a high or low LED comes on. If the burner has been out-of-range for more than three cycles the FQM goes into an "alarm mode". In this mode, the high or low LED flashes and a set of contacts are closed. These contacts can be used to work in conjunction with an existing home security system, or trigger any other type of alarm indicator. The service organization would then service the burner as needed, and reset the FQM.

The Insight Advanced Flame Quality Indicator was used in tandem with the FQM to provide an additional capability to monitor combustion data from all test sites remotely via the Internet. The AFQI also monitors FQM alarm status as well as cad cell and stack temperature sensor inputs. With this configuration, sensor data is collected and automatically uploaded to Insight's Webserver via a telephone connection. The data, received by a proprietary gateway application, is stored in a SQL Server database and processed to provide run-time information including: alarm status, flame signal, stack temperature, cumulative run-time, number of burner cycles, and run-time per cycle. 
Insight's monitoring website displays historical burner data in graphic format that quickly indicates cycling patterns, onset of combustion problems and trends associated with degradation of combustion. The monitoring website also provides the capability to automatically send alarm notifications via e-mail whenever the flame signal exceeds a high or low limit.

The test sites monitored by the AFQI required installation of an additional cad cell and 9VDC wall-type transformer power supply. A data logger was used to record ambient room temperature at a number of test sites.

\title{
Field Test Participants
}

To develop a representative set of homes for this field test assistance was sought from service companies in several states where oil heat is predominantly used. The objective was to get a diverse set of climates and conditions. The response from the organizations approached was very positive. Some organizations approached early in the program installed 10-20 units. Others that joined the project later installed just a few. The participating service organizations, roughly in order of number of units installed (with highest number first) are:

\author{
E.T. Lawson, Virginia \\ Santa Fuels, Connecticut \\ V.R. Boltz, Pennsylvania \\ Heritage Energy, New York (Catskill Region) \\ Agway Energy Products, New York (Finger Lake Region) \\ Sico, Pennsylvania \\ General Utilities, New York (Long Island)
}

In addition to the test sites listed above, several were installed in homes of BNL families and Long Island facilities of the U.S. National Park Service including the Fire Island Lighthouse. Energy Kinetics, Inc., a boiler manufacturer in New Jersey, installed several test units as well. For all organizations, BNL staff provided training on the project and made periodic visits to the organizations.

For every test site, basic data was collected during installation including: appliance type, burner manufacturer, tank location, venting arrangement, and domestic hot water arrangement. After installation, a basic combustion test was done to establish the performance baseline. A total of 83 units were installed during the project. Most of these were installed on boilers although the set also included commercial boilers, furnaces, and water heaters.

During normal operation, the AFQI makes a scheduled call to Insight's Webserver on a regular basis to provide information about the AFQI signal, the status of alarms, the burner run-time and cycling data. The time interval between calls can be programmed as desired but typically, a frequency of once daily was chosen for this study. In some cases 
more frequent calls were set up. The participating organizations could access and view the status of their installed units from Insight's monitoring website using a unique user name and password. When alarms occurred, the planned procedure was for the service organization to visit the site, document the condition of the burner, check the alarm status of the FQM and to correct any burner malfunctions encountered. Upon completion of this procedure, the FQM and $\mathrm{AFQI}$ were reset.

\section{Results}

This project is being completed at present and the final analysis and report will be available in the Fall, 2002. As of the present time, analysis of results for some service organizations is complete. For every site, final analysis includes a review of service history during the test period, flame quality signal trends from the AFQI, and the AFQI and FQM alarms that occurred. A set of outcome codes have been established and are being assigned to the test sites. These include:

1. No AFQI Alarms, justified

2. No AFQI Alarms, unjustified

3. No FQM Alarms, justified

4. NO FQM Alarms, unjustified

5. AFQI Low, justified

6. AFQI High, justified

7. AFQI Low, unjustified

8. AFQI High, unjustified

9. FQM Low, justified

10. FQM High, justified

11. FQM Low, unjustified

12. FQM High, unjustified

13. FQM unknown, justified

14. FQM unknown, unknown, unjustified

15. Monitoring Equipment Problems

16. Extraordinary Boiler/Furnace Equipment Problems

At some of the sites service was required during the test program and the AFQI and FQM's needed to be reset. In these cases, the test period may be divided into two parts and separate outcome codes may be assigned for each test period.

In addition to the outcome codes, a set of fault codes are being assigned based on the type of problem which occurred at the sites. As might be expected, most of the problems observed are fuel system related: fouled nozzles, plugged fuel lines and filters, and fuel pump problems.

At the beginning of the project participating organizations were invited to include sites in the program which have some history of problems. While some were certainly in this category, the population set typically included a mix of sites including service 
organization facilities, homes of service technicians and other people directly associated with the service organizations, and typical customers.

When alarms occurred, efforts were made to identify the causes. However, in some cases either the unit was serviced before the cause could be established or no clear cause for the alarm could be identified. In looking for a cause for an alarm, the first test is a basic combustion test in steady state and in many cases this will identify the presence of a problem. In a significant number of the test sites, however, the problem was traced to a malfunction with either ignition or cutoff, which leads to head coking and fuel deposits in the burner air tube. While these malfunctions lead to alarms they don't always show up as problems in steady state combustion performance. In the results analysis, being completed at present, every effort is being made to resolve as many of the indicated alarms as possible.

Throughout the test project, numerous burner malfunctions were clearly identified when FQM alarms were logged. Some examples include:

Example 1 - The AFQI flame signal data indicated sharp fluctuations at this site from day to day, well out of the acceptable operating range. The problem was traced to a crack in an underground oil tank that allowed water inflow. The tank was replaced and the problem corrected.

Example 2 - Shortly after a fuel delivery, the AFQI reported flame signal data that started drifting rapidly out-of-range. Within a week, an alarm condition was indicated by the FQM. Upon inspection of the site, a very high pump suction pressure was measured and it was found that the oil line and filter were blocked with sludge. While under high pump vacuum, air was being drawn into the fuel line and nozzle assembly leading to: after-drip, oil vapor drifting back into the burner air tube, and nozzle coking. Even under these conditions, the burner continued to operate. The situation was corrected and the AFQI subsequently reported the flame signal returned to normal.

Example 3 - This site monitored a cast iron boiler with a history of soot-up problems which was a concern to the service organization. Over a period of several months, the AFQI signal was observed to be drifting toward the out-of-range limit. BNL staff along with a service technician visited this site. Upon inspecting the site, the FQM was observed to be in an alarm mode. On shutdown, the burner was observed to rumble lightly, indicating poor shut-off. Steady state combustion performance was determined to be acceptable. The service technician observed the flue openings were heavily sooted and that the unit was heading rapidly for another problem. The heat exchanger was cleaned and the fuel pump replaced which greatly improved shut-off performance. The FQM system was credited with preventing a serious repeat problem at this customer site.

Example 4 - An alarm was noted at one site where a boiler was being monitored. The service company did not respond when alarm notification was received. Several days later they received a call that heavy smoke was observed from the chimney. When the 
service technician arrived the refractory combustion chamber was found to have collapsed. The boiler was replaced.

Example 5 - One site had monitoring equipment on both a boiler and a water heater and both units had flame signals which were very steady for months. Suddenly, one morning an alarm was reported on both units at about 5 AM. At about 8 AM the homeowner called in, reporting that he had run out of oil (this was a "will-call" account).

Figure 1 shows the trend in flame quality signal over time for a properly operating unit as displayed on the Insight web site. Figure 2 shows the flame signal trend for a burner which developed a blocked fuel filter shutdown.

Beyond flame quality measurement, the project results provide interesting information on field operating conditions. The Insight database provides cumulative run-time and number of burner cycles which proved to be very useful. From this data, the average burner "on" time, cycling rate, and if the nozzle size is known, daily fuel consumption can be calculated.

Figure 3 shows daily run times and number of cycles for a boiler with a tankless coil in the winter. Figure 4 shows the same information for the same boiler in the summer.

For any site the average burner run-time can be found by simply dividing the total runtime by the total number of cycles. Figure 5 shows the distribution of average run-times for all units. The mean of all these run-times is 5.5 minutes.

Another interesting analysis involves examination of how cycling rate and run-time vary with outdoor temperature. In the analysis, the number of degree days assigned to each day can be used as a measure of the average outdoor temperature and this information is available from either local weather services or the participating service organization. Degree days are counted from midnight to midnight and the AFQI's call at different times during the day. Because of this, the approach being used is to analyze run-time and cycle data for a 24 hour period over a two day period, during which the average outdoor temperature was very steady. The 24 hour period might be, for example 10 AM one day to $10 \mathrm{AM}$ the next, depending upon when the AFQI called. The degree days per day value for the two adjacent days was applied to that time period.

Figure 6 shows results in the form of Run-time vs. Degree Days for some selected sites with a linear fit-line through each data set. For every tested location there is a "design outdoor temperature". Design outdoor temperature is the outdoor temperature upon which residential heat load calculations are based. From the design temperature there is a corresponding number of degree days per day. By extrapolating the run-time trend line to the design point, the amount of time that the burner would run on the "design day" can be determined. This number, represented in hours, is divided by 24 to determine the oversize factor for the heating appliance. For the units shown, the oversize factor is typically 2 . This information can be combined with firing rate and combustion efficiency to get a 
measure of the actual heat load for the house on the design day and aid in sizing replacement equipment.

Figure 7 shows an example of the variation of average run-time per day with outdoor temperature. It might be expected that the average run-time increases as the weather gets colder and heat demand increases. For some of the sites, a small increase in average runtime is observed under the coldest conditions although in others, the average run-time is fairly constant over the year. This implies that the run-time is very strongly constrained by the capacity of the system to absorb the heat and deliver it to the house. Longer runtimes would require a higher ratio of hydronic system distribution capacity to firing rate, or possibly higher mass boilers for a given firing rate.

The run-time information, provided by the flame quality monitoring can be combined with firing rate information to estimate fuel consumption, providing an alternative to the degree day method of planning deliveries. To illustrate this, an analysis was done at one site with a nominal nozzle size of 1.25 gph. Delivery data was obtained for this site over a one-year period. Using the data for the first delivery at this site during the test, the amount of oil predicted to be delivered was $8 \%$ (or 13 gallons) lower than the actual delivery. Based on the first delivery data it was calculated that the actual firing rate was 1.35 gph (fuel pump pressure was not measured). Using the calculated firing rate, the actual delivery and the delivery predicted based on burner run-time were then compared for the next 6 deliveries. Figure 8 shows this comparison. The largest difference between the actual and predicted deliveries was 5.9 gallons. The average difference was 2.2 gallons.

\section{Conclusions}

The two-year test of the Honeywell FQM system will be completed by this Fall. Results to date have shown the system can be very useful in reducing service costs by providing early warning of fault conditions and extending time intervals between scheduled service. Some unresolved warning indications have also been received. Efforts are underway to resolve many of these. The information provided by flame monitoring can be used for other purposes including: evaluating cycling rate and identifying sites with short cycling rates, estimating oversize factors for units operating in the field, and accurately estimating actual oil usage based on run-time.

\section{References}

1. Butcher, T. Performance Control Strategies for Oil-fired Residential Heating Systems - Project Report. BNL Report 52250, July 1990.

2. Butcher, T., W. Litzke, and R. McDonald. Development And Technology Transfer Of The BNL Flame Quality Indicator For Oil-Fired Applications. BNL Report 61860, September, 1994.

3. Troost, H., T. Butcher, and A. Rudin, Paper No. 01-02, Field Test of the Flame Quality Monitor, Proceedings of the 2001 National Oilheat Research Alliance Technology Conference, BNL Report 52625, April 2001. 


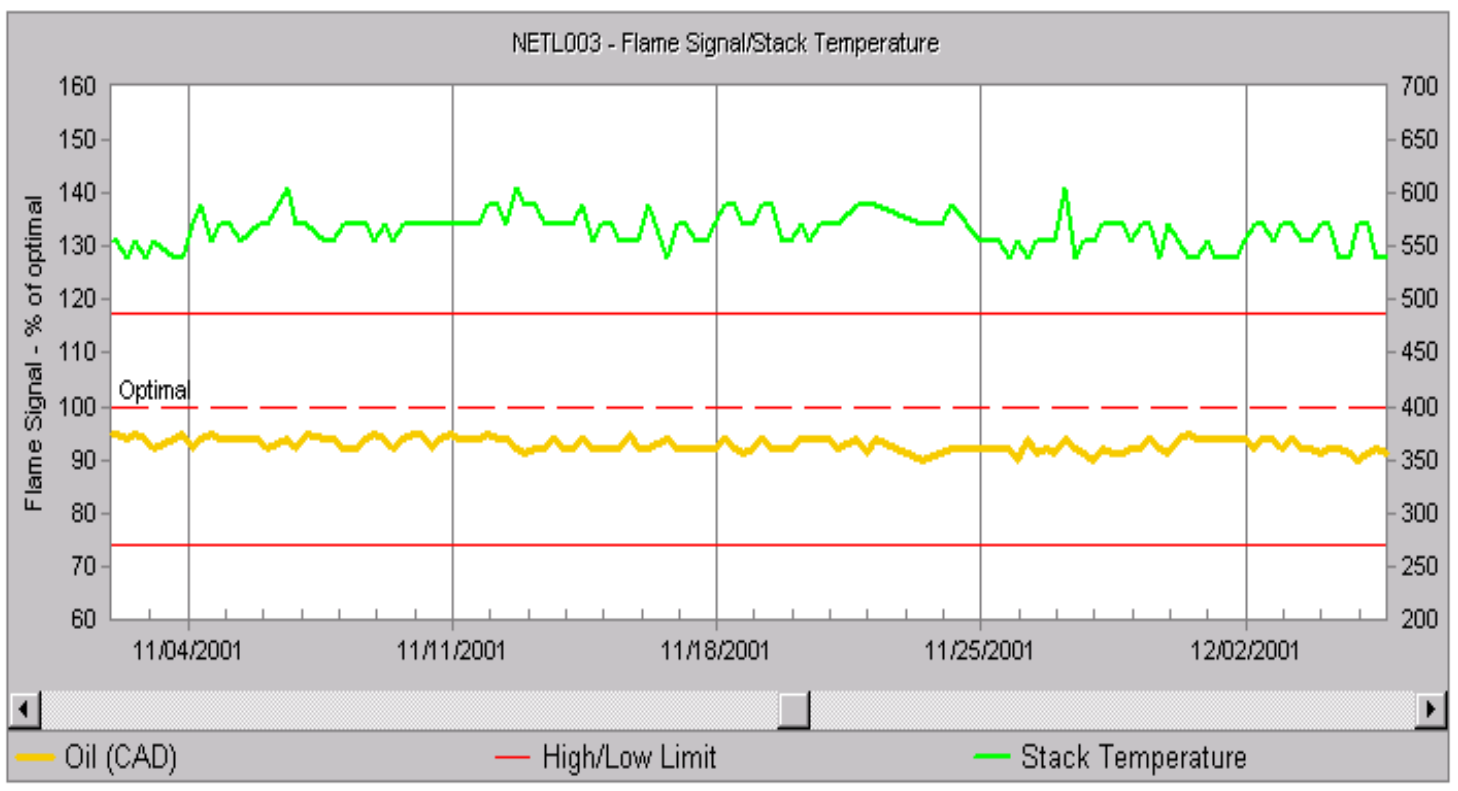

Figure 1: Example of signal trends in a properly operating boiler. Graphic from Insight web site. The lower line represents flame quality signal and the upper is flue gas temperature.

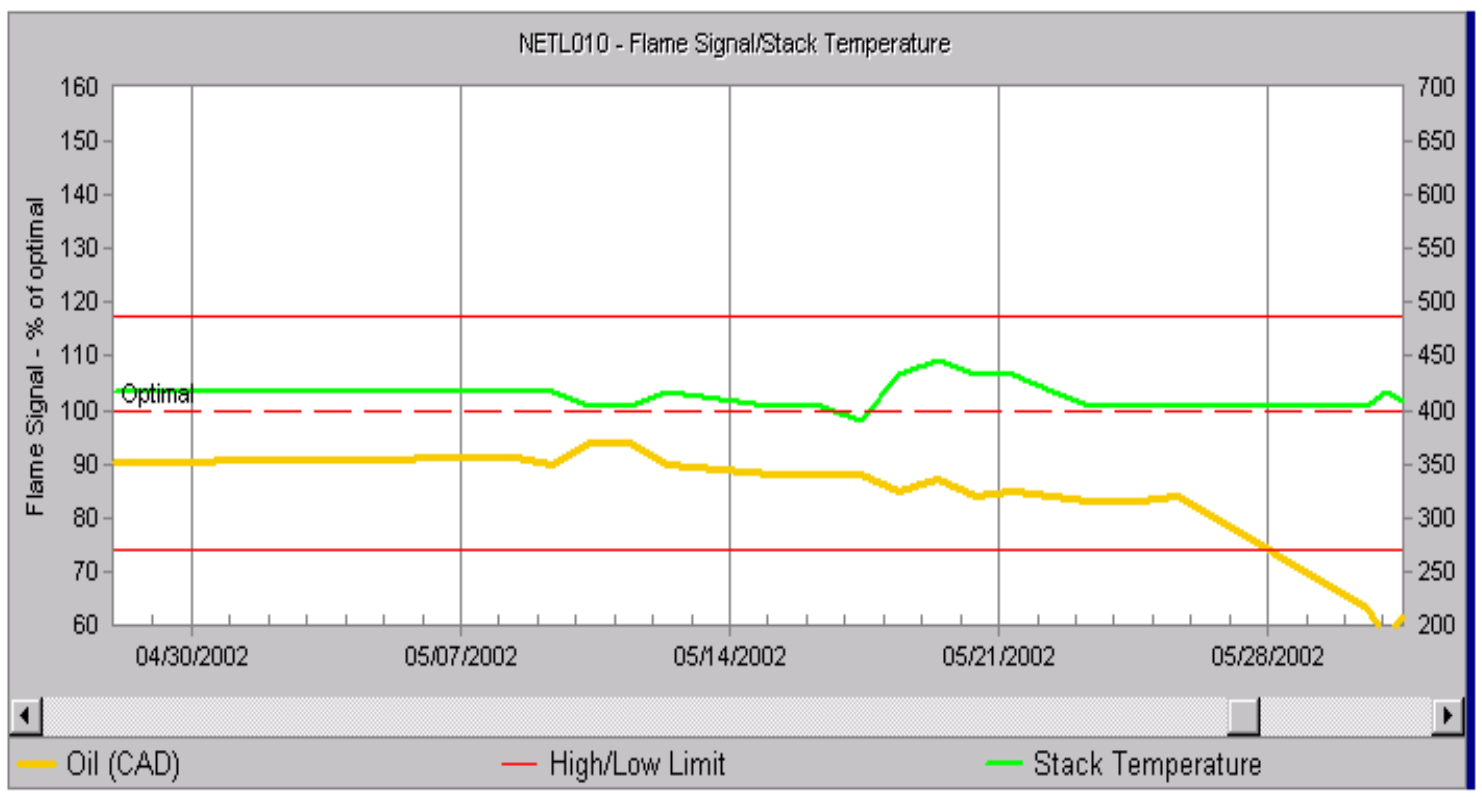

Tools Printable Version

Figure 2: Example of flame quality trend in the case of a burner problem. Fouling of the fuel line filter caused this alarm which led to a burner shutdown. 


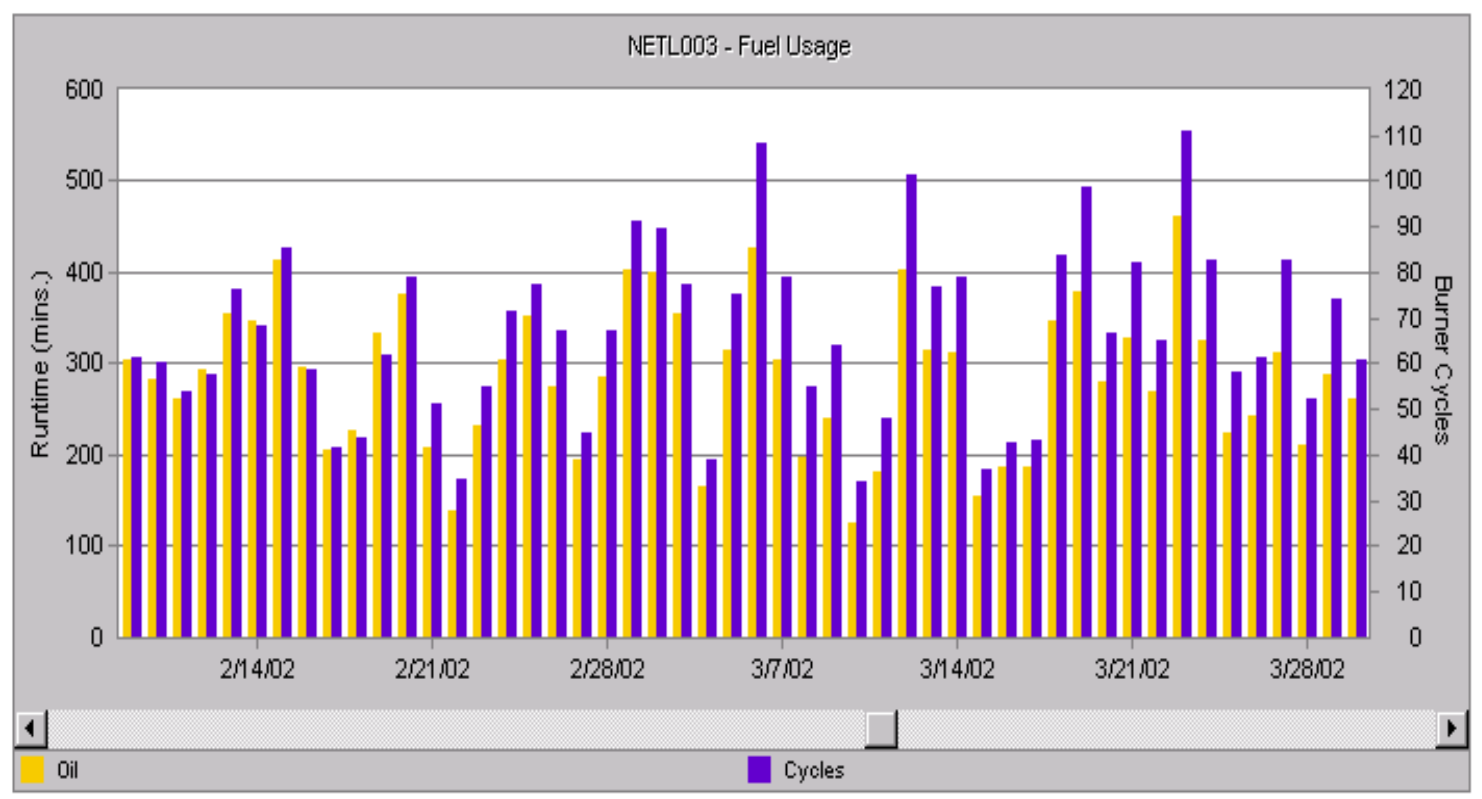

Figure 3: Example graphic from Insight monitoring web site. Run-time (light/yellow bars) and number of cycles (dark/blue bars) per day during winter.

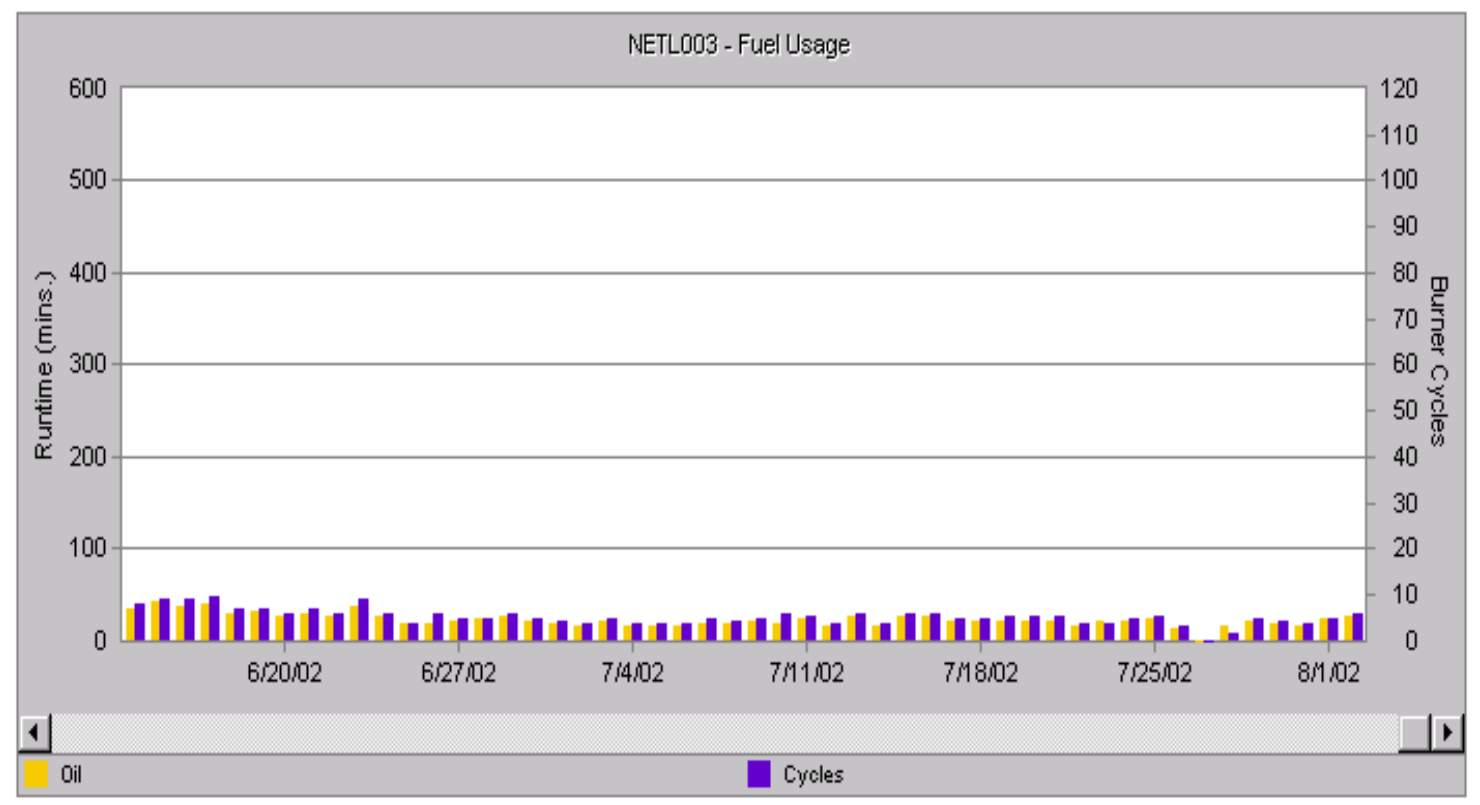

Tools Printable Version

Figure 4: Example graphic from the Insight monitoring web site. Run-time and cycles per day during summer. Boiler with a domestic hot water coil but very light domestic hot water load. 


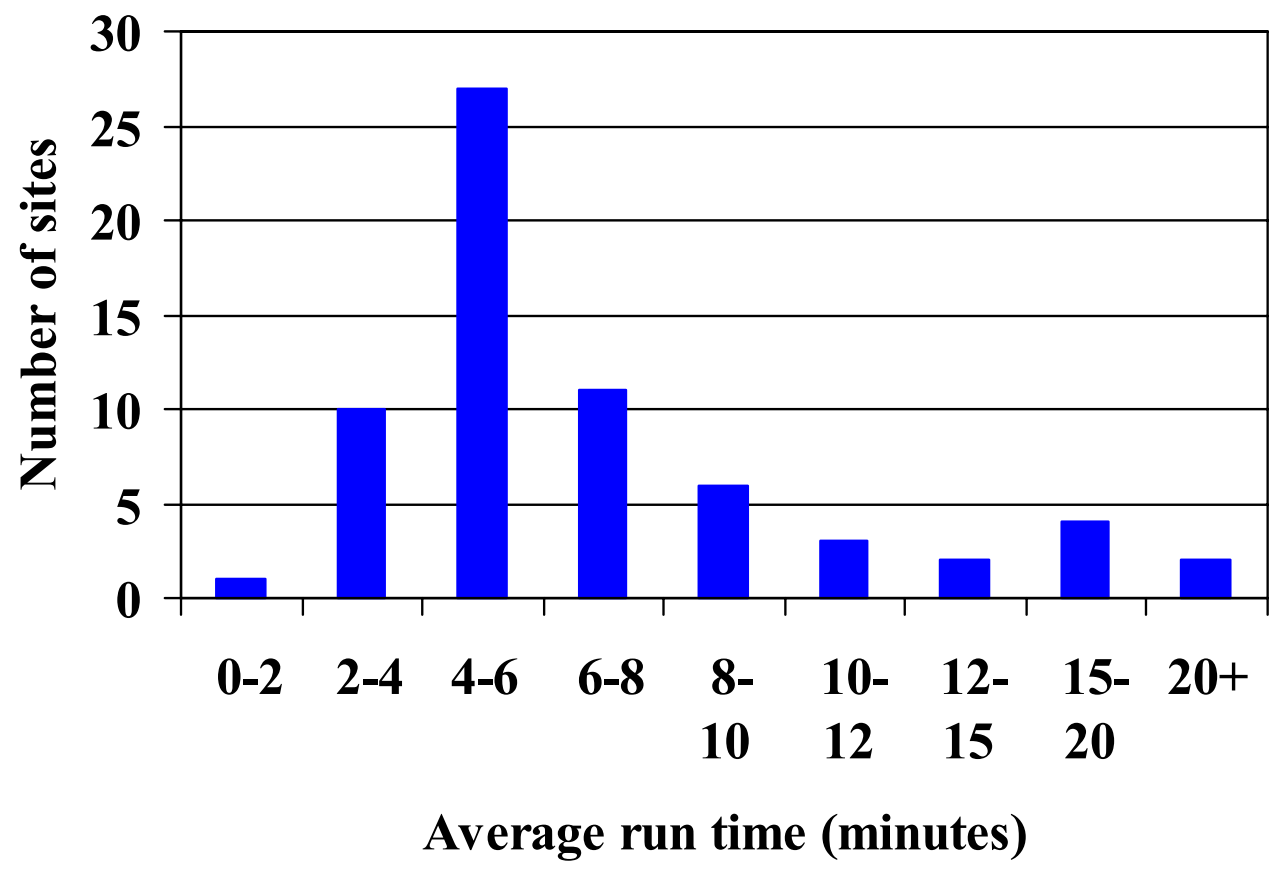

Figure 5: Distribution of average run-times for all units

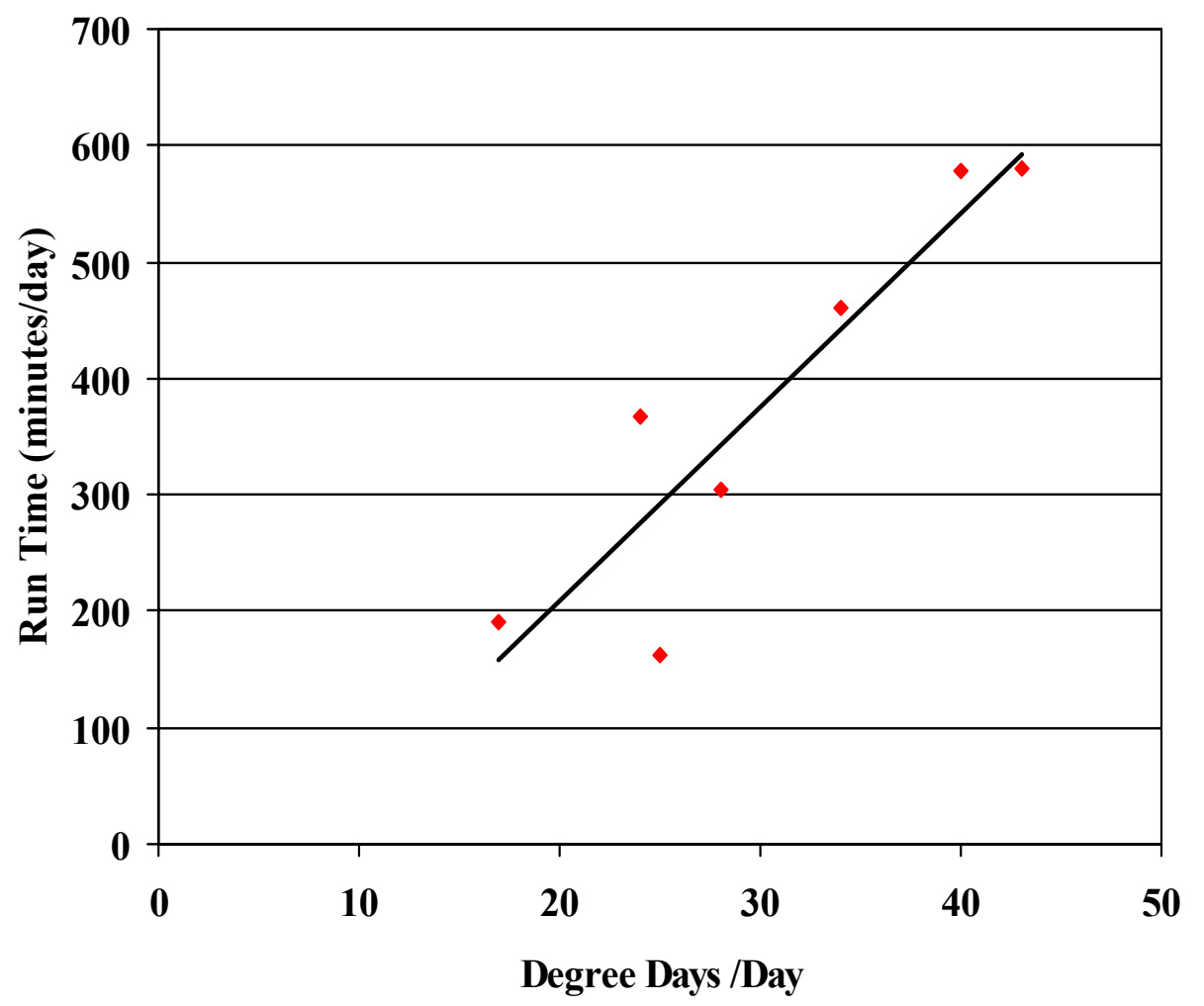

Figure 6: Example results from the monitoring web site. Run-time as a function of outdoor temperature 


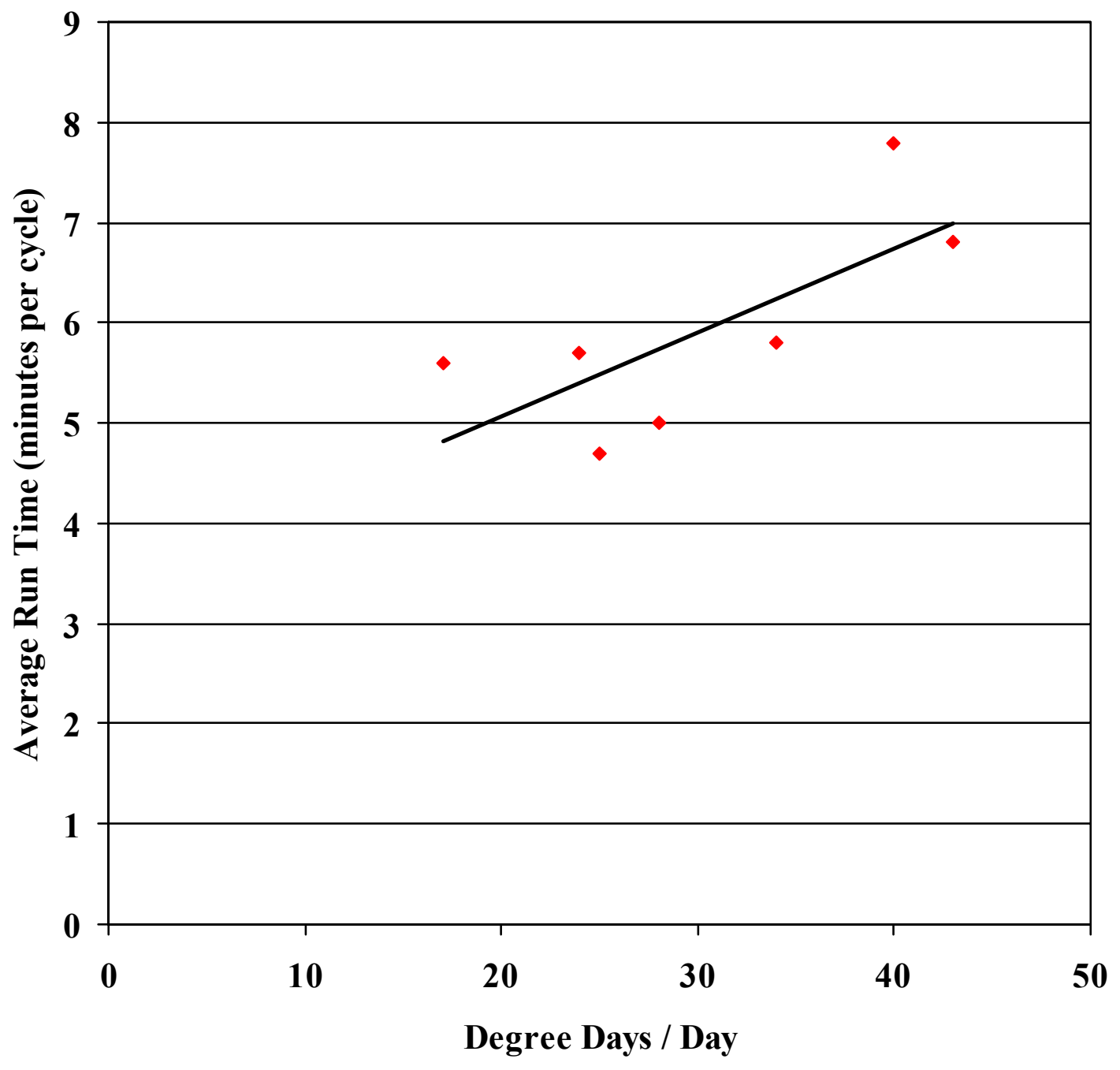

Figure 7: Example results from monitoring web site. Effect of outdoor air temperature on average run-time per cycle 


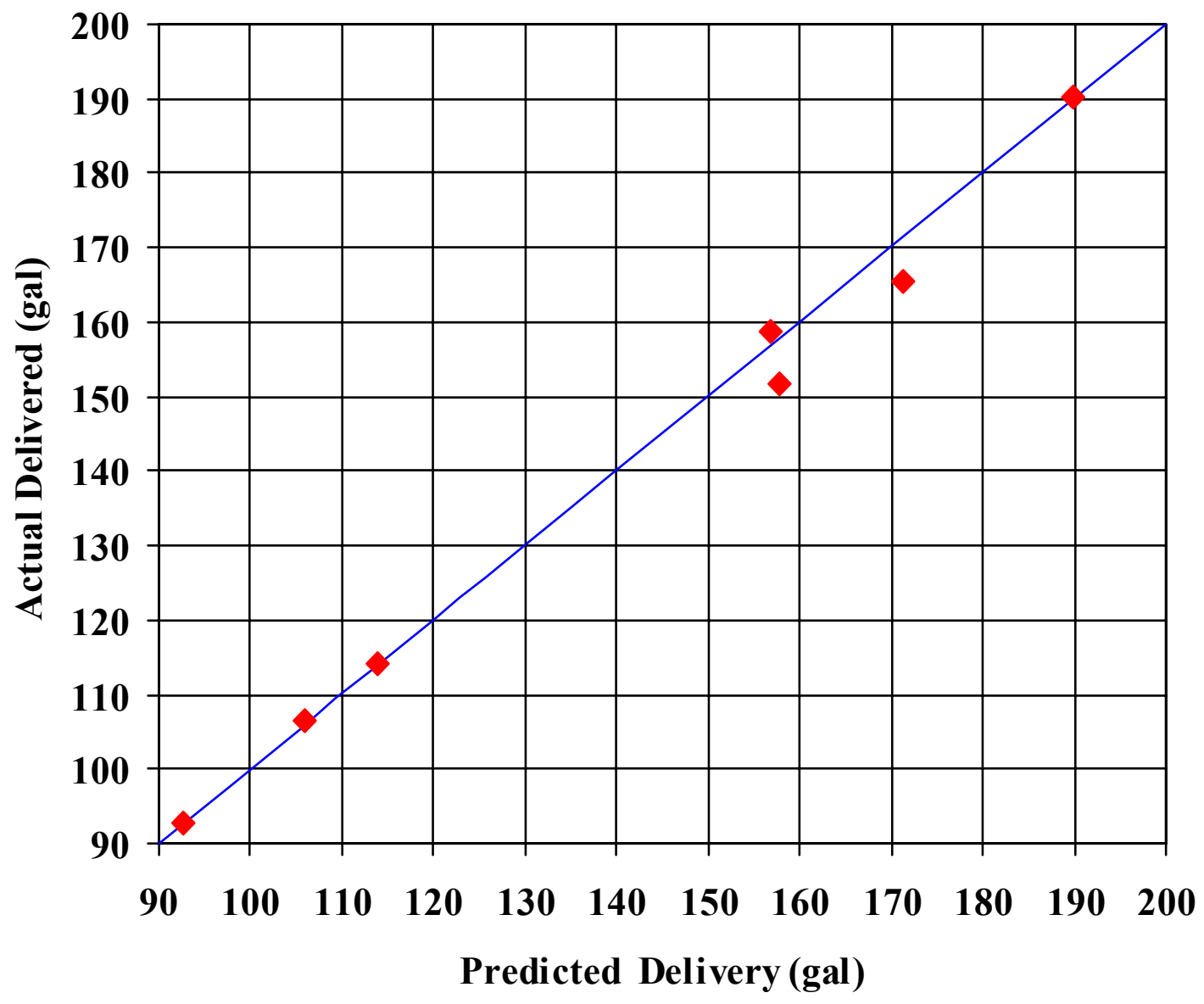

Figure 8: Comparison of actual amount of oil delivered to one site with the predicted amount based on run-time from the monitoring system. 


\section{Paper No. 02-13 \\ Assessing $\mathrm{PM}_{2.5}$ Emissions from Distillate Fuel Oil Heating}

S. Win Lee, I. He, T. Herage, E. Kelly and B. Young

CANMET Energy Technology Center-Ottawa

Natural Resources Canada

Ottawa, Canada. K1A 1M1

Phone: 613 996-3873

Fax: 613 992-9335

E-mail: swlee@nrcan.gc.ca

Internet: www.nrcan.gc.ca/es/etb/cetc 
Assessing $\mathrm{PM}_{2.5}$ emissions from distillate fuel oil heating

S. Win Lee, I. He, T. Herage, E. Kelly and B. Young

CANMET Energy Technology Center-Ottawa. Natural Resources Canada.

\begin{abstract}
The oil heating industry is anxious to understand the implications of scientific and regulatory issues relating to the new fine particulate matter (PM) regulations in North America. Although research is continuing to address apparent knowledge gaps in many areas including health and environmental impacts of fine PM, specific source sector contribution information is relatively scarce at present. While fossil fuel combustion systems are identified as particulate emitters, the relationships between stack emissions and ambient PM levels are difficult to elucidate due to the complex atmospheric transformation pathways involved. Source apportionment modeling methods are usually applied to identify PM contributions from various point sources to the regional ambient particulate concentrations that are subject to regulatory compliance. However, critical information such as source types, meteorological conditions, temporal and spatial data and source characteristic profiles are essential in source apportionment and the need for reliable emission data from specific sources becomes apparent.

CANMET, with the cooperation of Environment Canada and Canadian utilities, recently launched a new research program to examine fine PM concentrations from stationary combustion equipment. Research focuses on measurement and characterization of PM emissions under both stack and simulated ambient conditions, the latter being achieved by using a new source dilution sampler. To date, source characteristic profiles for $\mathrm{PM}_{2.5}, \mathrm{PM}_{10}$ and total $\mathrm{PM}$ from residential oil heating units and pilot-scale boilers, burning fuel oils and pulverized coals, have been established. Ongoing work emphasizes on the modification of the prototype measurement systems for field applications. As well, additional investigations are being conducted to examine the impact of variables such as fuel quality, operating conditions and equipment design on fine PM emissions to provide emission reduction strategies for the industry. This paper reports initial findings on the associations between distillate fuel properties and fine PM emissions.
\end{abstract}

\title{
INTRODUCTION
}

The U.S. Environmental Protection Agency (USEPA) promulgated revised National Ambient Air Quality Standards (NAAQS) for ozone and particulate matter in 1997 to address ambient concentrations of very fine PM (1). The particles with an aerodynamic diameter less than $2.5 \mu \mathrm{m}$, commonly known as $\mathrm{PM}_{2.5}$, are introduced to the standards based on the reported concerns over human health effects associated with these respirable substances. Several studies have shown associations between fine PM concentrations and adverse health effects including increased mortality and cardiopulmonary and cardiovascular illnesses in most susceptible people although only a few key reports are referenced here (2-5). The effect of ambient fine PM on the visibility degradation has also been widely reported in industrialized countries. Similar regulatory considerations are given in Europe with the world health organization's

acknowledgment of the evidence of associations between PM concentrations and adverse effects on human health at low levels of exposure commonly encountered in developed countries (6). The Office of Air and Radiation of the EPA reported the U.S. implementation timeline for PM standards in 2000, as shown in Table 1(7). 
Table 1. The US implementation timeline for PM standards

\begin{tabular}{l|l}
\hline 1997 & EPA issues Final PM $_{2.5}$ NAAQS \\
$1998-2000$ & Ambient PM monitors put in place nationwide \\
$1999-2003$ & Collect monitoring data \\
2002 & EPA completes 5-year scientific review of standards \\
$2003-2005$ & EPA designates non-attainment areas \\
$2005-2008$ & States submit implementation plans for meeting the standard \\
$2012-2017$ & States have up to 10 years to meet the standards plus one year extensions \\
\hline
\end{tabular}

In Canada, the desirable limit for ambient $\mathrm{PM}_{2.5}$ is stipulated under the Canada Wide Standards (CWS) and $\mathrm{PM}_{10}(\mathrm{PM}$ with aerodynamic diameter less than $10 \mu \mathrm{m})$ is listed as one of the toxic substances in the priority substances list (PSL) of the Canadian Environmental Protection Act (8). Under the CWS, $30 \mu \mathrm{g} / \mathrm{m}^{3}$ of PM concentration reported by 24-hour averaging time, based on the $98^{\text {th }}$ percentile ambient measurement annually averaged over three consecutive years, is to be achieved by year 2010. A review process is being planned for complete scientific, technical and economic analysis to reduce information gaps and uncertainties by the end of the year 2005 to establish, revise or supplement the CWS for the year 2015 as appropriate. Most recently, $\mathrm{PM}_{2.5}$ and $\mathrm{PM}_{10}$ precursors such as $\mathrm{NOx}, \mathrm{SOx}, \mathrm{NH}_{3}$ and volatile organic compounds have been declared toxic by adding them to the schedule I of the PSL in July 2000 and June 2001 respectively. Under the advisement of CCME, joint actions by the federal and provincial authorities are to be taken to reduce emissions that contribute to PM and ground-level ozone by developing comprehensive, multi-pollutant emission reduction strategies for Canadian industries. The electric power generation, base metal smelting and pulp and paper industries are among the six sectors selected, based on their extensive utilization of fossil fuels.

Fossil fuel fired systems release many air emissions including gaseous and particulate emissions during combustion. Stationary combustion generated PM contain carbonaceous matter, acidic species and many elements that are of significant health concern. While it is generally accepted that combustion generated particles have greater impact on human health than naturally occurring particles, the actual mechanisms and contribution by the chemical and size characteristics of PM are currently not well understood. Moreover, actual contribution of PM from the combustion sources to ambient concentrations is difficult to elucidate because of complex transformation under diverse meteorological conditions and the contributions from other nearby sources. Source apportionment methods are usually applied to determine individual PM contribution from different point sources to ambient pollution, known as receptor concentrations (9-13). The size and chemical composition of PM from each source type, known as source signatures or source characteristic profiles are essential in source apportionment modeling. However, the current source-emission inventory data have been identified as inadequate since samples have been collected using conventional high temperature filter methods. Previous studies have established that many existing PM data obtained using in-stack samplers and EPA Method 5 equipment are representative of neither the size distribution nor the chemical composition of stack particles after they reach the atmosphere (14). Simulation of near ambient, plume conditions can be achieved by source dilution sampling of PM. The source dilution approach allows for atmospheric transformation processes of the particles and thus provides ambient-comparable, source signature profiles for source apportionment modeling. At present, fine PM data from industrial sources are limited since high temperature sampling techniques are normally used. In addition, inadequacies still exist in the reported studies, especially in optimization and control of experimental parameters such as dilution ratio, 
residence time and relative humidity inside the dilution tunnel. A reliable fine PM measurement protocol is highly desirable for the following important reasons; to produce new source PM characteristic information of major combustion point sources for PM management strategies for the plant; to provide much needed source-receptor relationship information for science-based policy formulation; and in assessing the effectiveness of PM control technologies for stationary combustion systems.

In view of these requirements, a new source fine PM measurement methodology was developed to address the apparent information gaps (15-20). Research is being conducted at Natural Resources Canada with additional support by two Canadian utilities and Environment Canada with the objectives of examining source PM characteristics from the electrical power generation sector. Two prototype samplers have been developed for the combustion units having low stack velocities $(<5 \mathrm{~m} / \mathrm{s})$ and medium velocities $(<20 \mathrm{~m} / \mathrm{s})$. The larger sampler is being retrofitted for field measurement on utility-scale boilers. The basic sampling protocol involves dilution of flue gas with purified air by 20 to 40 times inside a dilution maintained at a $40 \%$ relative humidity to allow for cooling and simulation of atmospheric transformation processes. Portions of the diluted gas are withdrawn, while maintaining isokinetic sampling, through selected cyclone and impactor inlets and filter packs to collect the PM fractions. The method provides mass concentrations of $\mathrm{PM}_{2.5}, \mathrm{PM}_{10}$ and total $\mathrm{PM}$ and their size and chemical composition information. To date, fine PM emissions from the combustion of diesel fuels, No. 2 and No. 4 heating fuels, and pulverized coal have been determined and characterized using the two samplers. A recent investigation addressed the association between fuel oil properties and fine PM emissions from residential oil-fired combustion systems. This paper summarizes the preliminary observations from this research conducted under accelerated laboratory operating conditions, as it related to PM emissions from combustion of fuel oils containing different sulphur concentrations.

\section{MATERIALS AND METHODS}

Experimental fuels

This investigation included five petroleum distillate fuel oils with sulphur contents of 0.05 to $0.6 \%$. Four test fuels were prepared using a low sulphur diesel fuel, having $0.05 \%$ or 500 ppm sulphur, as a stock and by adding known quantities of sulphur-doping agent, ditertiary dibutyl sulphide. The fuels contain nominal concentrations of $0.05,0.1,0.3$ and $0.6 \%$ sulphur by mass. The fifth fuel is a regular No. 2 type heating fuel oil. The fuels are designated LD-0.05, LD-0.1, LD-0.3, LD-0.6 and No. 2. Table 2 gives properties of the light distillate fuels.

Table 2. Properties of Light Distillate Fuels

\begin{tabular}{l|ccccc}
\hline \multicolumn{1}{c|}{ Properties of Fuel Oil } & LD-0.05 & LD-0.10 & LD-0.30 & LD-0.60 & No. 2 \\
\hline \hline Ultimate analysis $(\mathrm{wt} \%)$ & & & & & \\
$\quad$ Carbon & 87.60 & 86.63 & 86.55 & 86.05 & 86.68 \\
Hydrogen & 13.30 & 13.47 & 13.35 & 13.23 & 13.40 \\
Sulphur & 0.06 & 0.10 & 0.31 & 0.62 & 0.20 \\
Ash & 0.00 & $<0.01$ & $<0.01$ & $\mathrm{NA}$ & 0.00 \\
$\quad$ Nitrogen & 0.004 & 0.005 & 0.005 & 0.004 & 0.007 \\
Density at $15^{\circ} \mathrm{C}\left(\mathrm{kg} / \mathrm{m}^{3}\right)$ & 838.0 & 838.3 & 838.9 & 839.5 & 847.2 \\
Gross calorific value $(\mathrm{cal} / \mathrm{g})$ & 10885 & 10903 & 10896 & 10893 & 10823 \\
Gross calorific value $(\mathrm{MJ} / \mathrm{kg})$ & 46 & 46 & 46 & 46 & 45 \\
Gross calorific value $(\mathrm{Btu} / \mathrm{lb})$ & 19596 & 19628 & 19615 & 19610 & 19484 \\
Kinematic viscosity at $40^{\circ} \mathrm{C}(\mathrm{cSt})$ & 2.3 & $\mathrm{NA}$ & $\mathrm{NA}$ & 2.3 & $\mathrm{NA}$ \\
\hline
\end{tabular}




\section{Fuel Oil Combustion Test Facility}

A cast iron boiler Model Starfire 3 manufactured by Utica Boilers of Utica, NY, U.S.A. was used. The boiler is rated at $30 \mathrm{~kW}$, heat capacity and is equipped with a high efficiency, Beckett model AF-2 oil burner. The combustion unit is located inside a constant temperature room that can provide similar temperatures for the test runs. The water circulation system and pneumatic control valves were operated using computer-controlled data acquisition software with PID (proportional, integral and derivative) logistics to maintain the boiler inlet and outlet water temperatures at $54^{\circ} \mathrm{C}$ and $83^{\circ} \mathrm{C}$ respectively. Continuous emission analyzers incorporated in the test rig measured the gas phase emission concentrations of $\mathrm{O}_{2}, \mathrm{CO}_{2}, \mathrm{CO}, \mathrm{NO}_{\mathrm{x}}$ and $\mathrm{SO}_{2}$ concentrations in the flue gas. The operation of the entire test facility is automatically controlled by a dedicated computer system in LabVIEW.

The fine PM measurement system and the method protocol have been previously reported (15-20). Particulate samples are later analyzed in a receptor-comparable manner for mass, size distribution, carbon, trace element concentrations and soluble sulphates. Briefly, particle size distribution was examined by transition electron microscopy (TEM); trace elements were determined by energy dispersive X-ray fluorescence (XRF); organic and elemental carbon contents by thermal-optical reflectance procedure and particle bound acidic species such as sulphites, sulphates, nitrates and hydrogen ions by ion chromatography (IC). Mass determination of all PM fractions was carried out by gravimetry using a microbalance placed inside a humiditycontrolled chamber maintained at $40 \%$ relative humidity.

\section{Experimental Procedures}

The test boiler operation was optimized using a reference No. 2 heating oil. Since the experimental results are required in a short time frame, accelerated laboratory simulation procedure was used to shorten laboratory operation time. A burner setting between Baccharach smoke No. 1 and No. 2 was selected to attain sufficient filterable PM mass concentrations within a reasonable sampling period. While this setting shortens the PM sampling time, this may also reflect realistic field conditions that can be found in a moderate percentage of homes. Most surveys of field burner settings indicate a wide variance in smoke numbers and most of them show smoke levels higher than number 2(21). More important, this selected setting provided very low excess air and high efficiency conditions at $\mathrm{CO}_{2}$ concentrations of $12.5-12.9 \%$ and $\mathrm{O}_{2}$ concentrations of $3.5-4 \%$. This setting provides a dynamic appliance efficiency of about $83 \%$, which is approaching the optimum conditions for a residential oil-fired boiler. Therefore, all fuels are evaluated after the burner is adjusted each time to attain the $\mathrm{CO}_{2}$ and $\mathrm{O}_{2}$ levels selected above. This criterion is considered the best compromise for this experimental work. Adjusting the burner at the same combustion air supply will not necessarily provide the best and fair operating conditions for all fuels since each fuel has optimized conditions that are different from the others. In other words, a cleaner burning fuel may be unnecessarily compromised in its air setting if it were operated under the same conditions selected for an average or poor-performing fuel. The combustion experiment for each fuel included a short cycle emission monitoring run and one continuous boiler "on" period, during which PM measurement was performed using the source dilution PM sampler. The short cycle test has a 1 hour steady state burner "on" mode followed by five $10 \mathrm{~min}$ "on" /10 min "off" cyclic operation. The fine PM measurement procedure usually requires 20-45 hours of continuous burner "on" operation, depending on the PM emission rate of the fuel. A minimum of three experiments for each fuel was conducted under both the short cyclic operation and the long PM sampling procedures. 


\section{RESULTS AND DISCUSSIONS}

\section{Emission Performance of the Fuels}

Boiler operating conditions were established to ensure that the experimental fuels were assessed without bias and that the results provided meaningful conclusions. Combustion experiments were therefore conducted under similar operating conditions, yielding comparable flue gas emission concentrations for all fuels. Table 3 gives the combustion results.

Table 3. Gaseous emissions of test fuels during steady state/cyclic operation and after normalizing to $3 \% \mathrm{O}_{2}$ concentrations

\begin{tabular}{|c|c|c|c|c|c|c|c|c|c|}
\hline & & \multicolumn{2}{|c|}{ LD-0.05 } & \multicolumn{2}{|c|}{ LD-0.10 } & \multicolumn{2}{|c|}{ LD-0.30 } & \multicolumn{2}{|c|}{ LD-0.60 } \\
\hline & & $\begin{array}{c}\text { Normal } \\
\text { Conditions }\end{array}$ & $3 \% \mathrm{O}_{2}$ & $\begin{array}{c}\text { Normal } \\
\text { Conditions }\end{array}$ & $3 \% \mathrm{O}_{2}$ & $\begin{array}{c}\text { Normal } \\
\text { Conditions }\end{array}$ & $3 \% \mathrm{O}_{2}$ & $\begin{array}{c}\text { Normal } \\
\text { Conditions }\end{array}$ & $3 \% \mathrm{O}_{2}$ \\
\hline \multicolumn{10}{|l|}{ Test Room Temperature } \\
\hline Stack Temperature & ${ }^{\circ} \mathrm{C}$ & $\begin{array}{l}19.3 \\
219\end{array}$ & $\begin{array}{l}19.3 \\
219\end{array}$ & $\begin{array}{l}20.1 \\
227\end{array}$ & $\begin{array}{l}20.1 \\
227\end{array}$ & $\begin{array}{l}20.5 \\
233\end{array}$ & $\begin{array}{l}20.5 \\
233\end{array}$ & $\begin{array}{l}20.1 \\
216\end{array}$ & $\begin{array}{l}20.1 \\
216\end{array}$ \\
\hline \multicolumn{10}{|c|}{ Stack emisions at steady state } \\
\hline Stack Carbon Dioxide & $\%$ & 12.8 & 13.3 & 12.7 & 13.4 & 12.7 & 13.2 & 12.4 & 13.1 \\
\hline Stack Oxygen & $\%$ & 3.7 & 3.0 & 3.9 & 3.0 & 3.7 & 3.0 & 4.0 & 3.0 \\
\hline Stack Sulphur Dioxide & ppm & 26 & 27 & 49 & 51 & 155 & 162 & 310 & 327 \\
\hline Stack Nitrogen Oxides & ppm & 98 & 102 & 112 & 117 & 114 & 119 & 102 & 108 \\
\hline Stack Carbon Monoxide & ppm & 26 & 27 & 24 & 25 & 21 & 22 & 22 & 24 \\
\hline \multicolumn{10}{|c|}{ Stack emisions during cyclic operation } \\
\hline Stack Carbon Dioxide & $\%$ & 12.9 & - & 13.0 & - & 12.8 & - & 12.7 & - \\
\hline Stack Oxygen & $\%$ & 3.5 & - & 3.6 & - & 3.5 & - & 3.6 & - \\
\hline Stack Sulphur Dioxide & ppm & 26 & - & 50 & - & 157 & - & 329 & - \\
\hline Stack Nitrogen Oxides & ppm & 98 & - & 110 & - & 117 & - & 104 & - \\
\hline Stack Carbon Monoxide & ppm & 30 & - & 29 & - & 23 & - & 31 & - \\
\hline Excess Air & $\%$ & 21.0 & - & 21.3 & - & 21.3 & - & 24.7 & - \\
\hline Dry Gas & lb./lb. Fuel & 17.2 & - & 17.3 & - & 17.4 & - & 17.8 & - \\
\hline
\end{tabular}

The emissions and temperatures in the table represent the average values of the monitored data from the boiler steady state runs during which PM sampling is conducted. The data show similar $\mathrm{CO}_{2}$ and $\mathrm{O}_{2}$ concentrations for all test fuels, which indicates that comparable boiler operating conditions were established. Similarly, comparable dynamic efficiency and excess air data were obtained for all combustion experiments.

The emission results suggest that gaseous emissions from the test fuels are similar except for the $\mathrm{SO}_{2}$ concentrations that increased with the increase in fuel sulphur. To evaluate emissions under comparable conditions, the results were normalized at $3 \%$ oxygen and are presented again in Table 3. $\mathrm{NO}_{\mathrm{x}}$ emissions do not appear to be influenced by the variation of fuel sulphur within the selected study range. The test fuels are not sufficiently different from each other to warrant a noticeable variation in $\mathrm{NO}_{\mathrm{x}}$ emissions. Figure 1 shows the effect of fuel sulphur on $\mathrm{SO}_{2}$ emissions. A linear positive effect of the fuel sulphur is noted. This phenomenon was observed during previous CANMET studies that examined the 0.01 to $1.2 \%$ fuel sulphur range. 


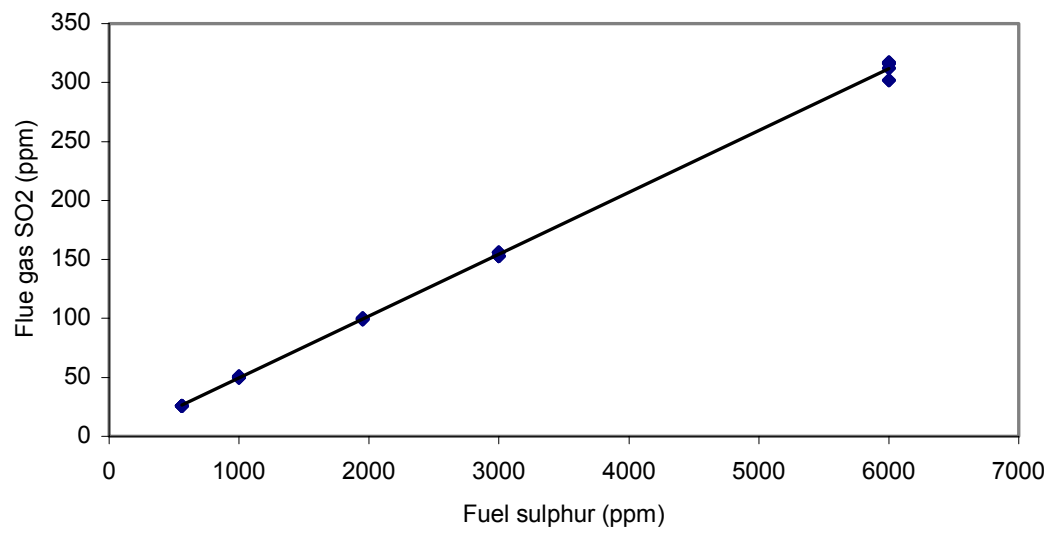

Figure 1 - Effect of fuel sulphur on flue gas $\mathrm{SO}_{2}$ emissions

Particulate Emissions

Table 4 gives PM emission results. Results are expressed in terms of filterable PM mass in $\mathrm{mg} / \mathrm{m}^{3}$ dry flue gas at standard temperature and pressure. Each sampling run collects two filter samples each for $\mathrm{PM}_{2.5}$ and $\mathrm{PM}_{10}$ fractions and one for the total $\mathrm{PM}$ fraction. Data for all replicated runs are given along with the calculated relative standard deviations. PM mass concentration results are reproducible within the same run as well as for replicate runs, although the absolute mass of particulate samples usually weighs about 250 to $1000 \mu \mathrm{g}$ per

Table 4 - Filterable PM mass concentrations of test fuels $\left(\mathrm{mg} / \mathrm{m}^{3}\right)$

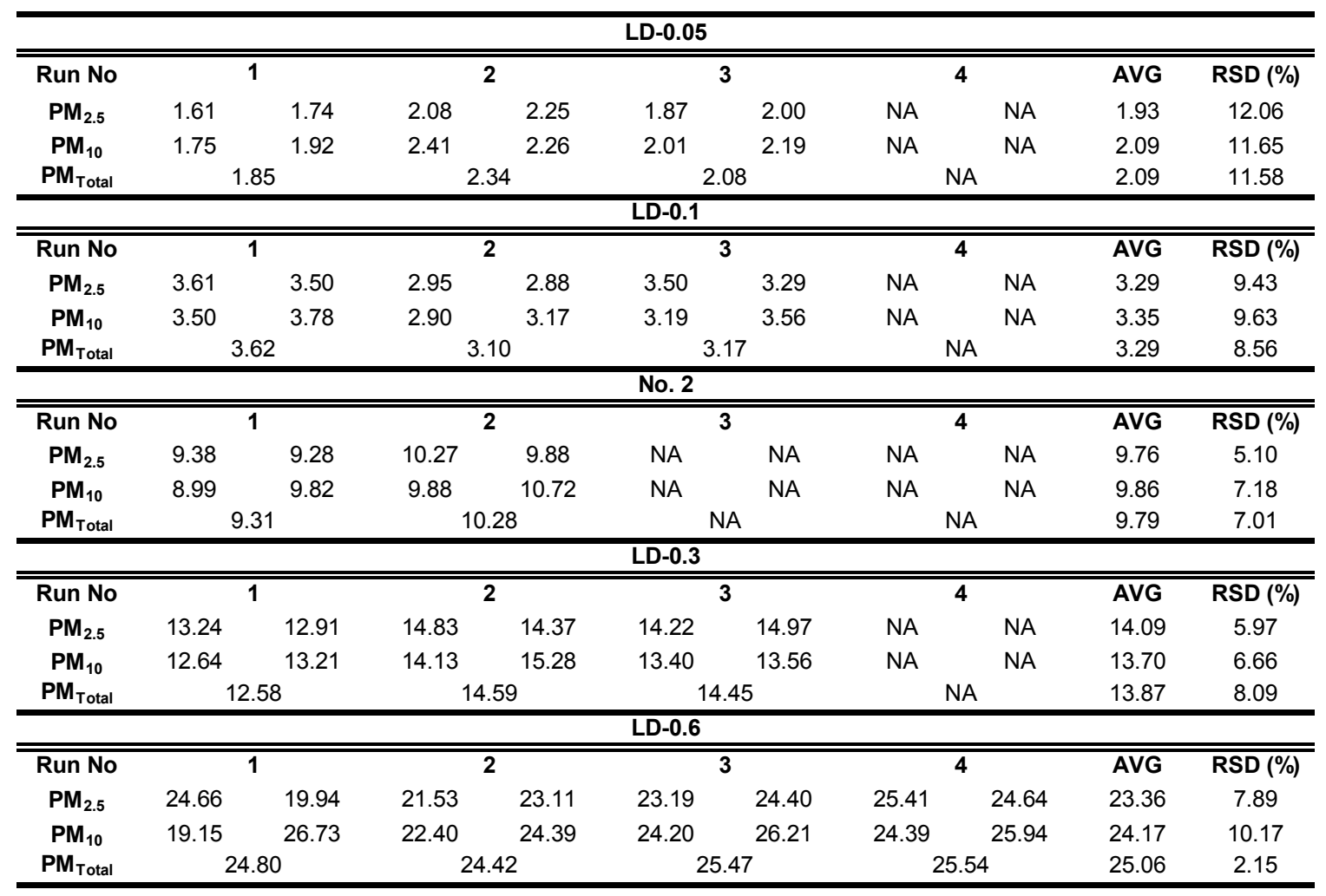

$R S D(\%)$-Relative Standard Deviation

NA-Not Applicable 
filter. A research project performed at the USEPA laboratories reported a total PM concentration of $6.1 \mathrm{mg} / \mathrm{m}^{3}$ for a fire tube boiler fired with No. 2 fuel containing $0.4 \%$ sulphur (22). CANMET results are in line with this literature value although the $70 \mathrm{~kW}$ EPA boiler is slightly bigger than the CANMET unit, which is rated at $30 \mathrm{~kW}$.

The data also show the apparent similarity of the mass concentrations for all PM fractions for a fuel. This suggests that all particulates emitted from distillate fuel fired residential boilers fall in the $\mathrm{PM}_{2.5}$ fraction. It should be noted that under the operating conditions described above this observation is only true for fuels containing up to $0.6 \%$ sulphur. Additional research is needed to confirm if this is applicable for other sulphur concentrations as well. Similar studies done for the transportation and mining engines reported that diesel fuels normally generate very small particles less than $1 \mu \mathrm{m}$ in diameter, known as ultra-fine PM. Previous research at CANMET using No. 4 type residual fuel oil showed the presence of about $10-15 \%$ of particles larger than $10 \mu \mathrm{m}$, in addition to $\mathrm{PM}_{2.5}$ and $\mathrm{PM}_{10}$. This will be discussed later when the $\mathrm{PM}$ size characteristic data are presented.

Data in Table 4 also reveals that the filterable PM mass concentrations increased with increased fuel sulphur content. This is demonstrated in Figure 2 for the $\mathrm{PM}_{2.5}$ and $\mathrm{PM}_{10}$ fractions. The similarity of the results for all PM fractions makes it difficult to see all data points in one graph. The results for No. 2 fuel oil also fall within the data set although its fuel hydrocarbon matrix is slightly different from those of diesel fuels. This observation appears to suggest that reduction of fuel sulphur could reduce particulate emissions from oil-fired residential heating units provided the equipment is properly maintained and operated near optimum efficiency

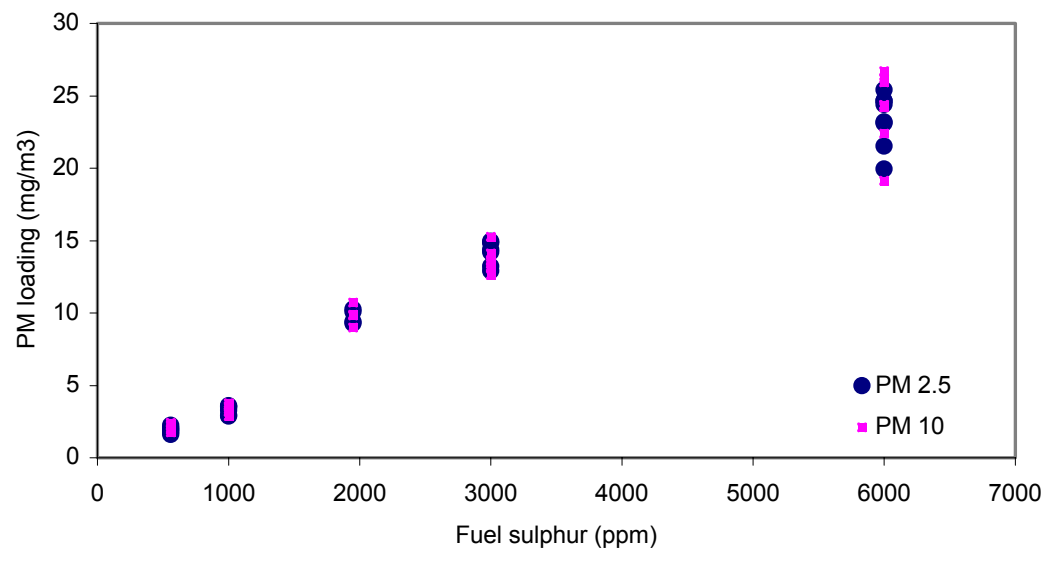

Figure 2 - Effect of fuel sulphur on $\mathrm{PM}_{2.5}$ and $\mathrm{PM}_{10}$ emissions

conditions. It should be noted that these results might not apply to other appliance and burner types since combustion conditions could be different among different units. In general, units that are functioning improperly would generate high levels of pollutant emissions and the effect of fuel quality on emission performance may not be apparent. A research study in Europe reported the mode of distributions of PM from small oil fired burners in the range of 10-15 nm (23). However, the researchers used a $150^{\circ} \mathrm{C}$ dilution air, instead of ambient comparable temperatures. Since atmospheric condensation and particle agglomeration processes cannot occur in high temperatures, particles are expected to be very small in such conditions.

PM Size and Morphological Characteristics

Initial size analysis of PM samples revealed that TEM analysis was required for these samples since the CCSEM (computer controlled scanning electron microscopy) technique, 
normally used for the PM analysis, would not provide accurate size data. Figure 3(a) shows a sample electron micrograph at an 85,000 magnification of a $\mathrm{PM}_{2.5}$ sample from LD-0.5 fuel. Figure 3(b) shows an overall field image of the same sample at 5,000 magnification. The clear droplet-like images are the pores of the filter media and only the opaque or dark images represent particulate materials. The laboratory confirmed two morphology types, the first type being the branched carbon chain agglomerate with round particles predominantly in the $0.05 \mu \mathrm{m}$ in diameter range. The second type represents clusters of round particles of comparable size. In addition, no distinction could be made between the $\mathrm{PM}_{2.5}, \mathrm{PM}_{10}$ and total $\mathrm{PM}$ samples or between those collected from the combustion of different test fuels. These observations suggest that all distillate fuels used in this study produced mainly carbon particles in the $0.05 \mu \mathrm{m}$ size range. This is comparable to the literature data, which report the size distribution of No. 2 fuel $\mathrm{PM}$ in the $0.02-3 \mu \mathrm{m}$ range (24) and that of No. 6 fuel with a mean diameter of approximately $0.1 \mu \mathrm{m}$ (25). Previous research at CANMET showed that No. 4 type residual fuel oils generated particles that are about $75-90 \%$ of the $\mathrm{PM}$ is $\mathrm{PM}_{10}$ and about $50-75 \%$ is $\mathrm{PM}_{2.5}$. The CCSEM data indicated the smallest PM size detected as $0.1 \mu \mathrm{m}$, which is almost the limit of the technique. In addition, the filter samples contain about $10-15 \%$ of particles that are larger than $10 \mu \mathrm{m}$.

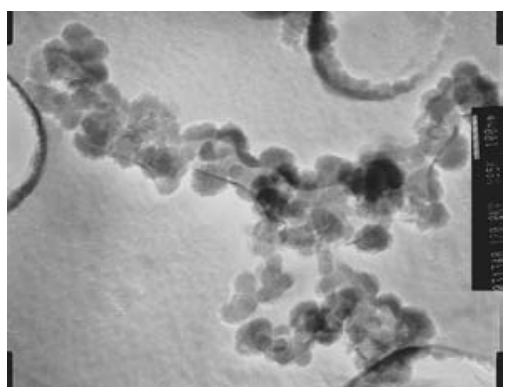

3(a)

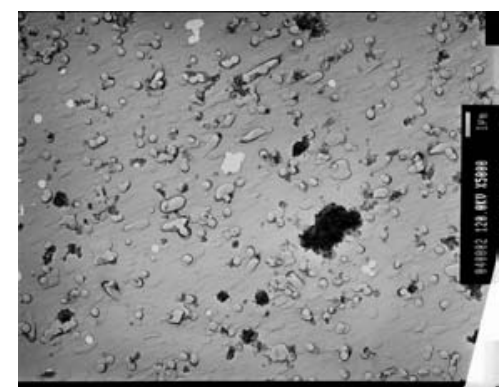

3(b)

Figure 3 - Typical transmission electron micrograph of $\mathrm{PM}_{2.5}$ agglomerate for $\mathrm{LD-0.05}$ fuel at 3(a) 85,000 magnification and 3(b) 5000 magnification

PM Chemical Composition

A better understanding of the chemical constituents of ambient particles is fundamental in bridging the knowledge gap between the air quality and its health effects. The acids and toxic trace elements found in ambient fine PM have been linked to a few known illnesses in humans and research animals. Ambient fine particles are generally made up of numerous species depending on the sampling location. These include acidic species such as sulphates and nitrates that exist as ammonium salts, carbon species, water, trace elements mainly in the form of oxides, earth crustal matter and other airborne fragments of natural and anthropogenic origins. On the other hand, source combustion PM is mainly composed of carbon species, condensed acidic species, water and trace elements. Sulphates and nitrates in PM are formed during the secondary PM formation process when primary $\mathrm{PM}$ such as $\mathrm{SO}_{\mathrm{x}}$ and $\mathrm{NO}_{\mathrm{x}}$ undergo a gas-to-particle transformation process. Sulphuric and hydrochloric acids also condense on PM surfaces but usually are detected as soluble sulphate and nitrate ions when the samples are dissolved in water. The CANMET protocol examined these PM constituents and the initial results are discussed.

Preliminary results showed soluble sulphate concentrations of $18-49 \%$ in filterable PM from combustion of fuels containing $0.05-0.6 \%$ sulphur. Their concentrations also increase with fuel sulphur content although a conclusive relationship has not been determined yet. This is to be 
expected since the flue gas $\mathrm{SO}_{2}$ levels clearly showed a linear positive relationship with fuel sulphur (Figure 1). Additional experiments are being planned to include a larger number of fuels to provide conclusive information. Current results are comparable to the data reported by California Institute of Technology (26) and previous CANMET data from No. 4 fuel oils (17). For No. 2 fuel combustion, CANMET data showed $35-40 \%$ of sulphate in the PM, where the California study reported 32\% sulphate, $29 \%$ elemental carbon, $6 \%$ organic carbon and $6 \% \mathrm{NH}_{4}$ ion. These $\mathrm{PM}$ concentrations are from industrial scale boilers burning No. 2 fuel oil. No appreciable amounts of soluble nitrates were detected in the PM samples from this study due to low concentrations of nitrogen oxides present in the flue gas.

Fossil fuel combustion produces organic carbons (OC) and elemental or graphitic carbons (EC), the latter being a key contributor to the atmospheric visibility degradation. Organic carbons are associated with numerous and complex organic species, some of which are known air toxic compounds. It has been reported that industrial oil-fired combustion systems tend to generate more elemental carbons than organic species, although their actual concentrations in PM highly depend on many variables including the combustion process itself, unit configuration, operation mode and fuel composition. Initial results from this study showed total carbon species concentrations of $11-73 \%$ in the PM samples from combustion of test fuels. The PM constituents of $\mathrm{OC}$ and $\mathrm{EC}$ concentrations range from $5-24 \%$ and $1-50 \%$, respectively. From No.2 fuel combustion, OC concentrations are 6-10\% and that of EC are 6-8\%. Since the OC/EC analysis technique is method dependent, the results are less accurate than the sulphate data. CANMET plans to conduct additional research to confirm these data. However, they are reasonably comparable to the reported literature discussed above (26). In addition, total carbon concentrations in PM appeared to decrease when fuel sulphur increased. This general reduction of carbon percentage in PM is to be expected since the percentage of sulphate in PM progressively increases as the fuel sulphur increases. Additional investigations are being planned to obtain conclusive information.

As for the trace metals, source combustion PM contains several oxides of mineral matter as contributed by the elements contained in the original fuel matrix. The current data revealed the absence of any measurable elements in the filterable PM. The very low, but similar concentrations of $\mathrm{Si}, \mathrm{P}, \mathrm{S}, \mathrm{Fe}$ and $\mathrm{Sn}$, that are in the ppm level, are noted in all samples regardless of the PM fraction or the sulphur content of the fuel. In other words, only minute quantities of trace elements are generated during combustion of diesel and No. 2 fuel on residential heating equipment. This can be expected since most of the light and middle distillate fuels contain only minute amounts of inorganic trace elements.

In summary, this study provides new information on ambient-comparable, fine PM emissions from residential combustion unit burning diesel and No. 2 heating fuel oils. It is expected that future research will reveal additional fine PM size and chemical property data that are of great benefit to the regulators, appliance manufacturer and fuel producers.

\section{REFERENCES}

1. Clean Air Act Amendments, Public Law 102-549, 104 Stat., November 15, 1990, 2399-2712.

2. Pope, C.A. In Particulate Matter: Health and Regulatory Issues. Air and Waste Management Association, 1995, VIP-49, 60-77.

3. Dockery, D.W. and Pope, C.A. Annu. Rev. Public Health 15, 1994, 107-132.

4. Bates, D.V. Environ. Res., 1992, 59, 336-349. 
5. Dockery, D.W., Schwartz, J., Spengler, D.J. Environ. Res., 1992, 59, 362-373.

6. Krzyzanowski, M.; Rolaf van Leeuwen, F.X. and Younes, M. In Health Effects of Particulate Matter in Ambient Air. AW\&MA, 1997, VIP 80, 25-29.

7. Brenner, R. Particulate Matter: the Federal Perspectives. In Proceedings of the Air Quality II Conference. September 2002. McLean, VA. U.S.A.

8. Canada Wide Standards. For PM and Ozone; Canada Gazette, February 5, 2000, Part 1, Vol. 134, No.6, 324-332; Canada Gazette, May 27, 2000, Part I Vol. 134, No.22, 1343-1645.

9. Scheff, P.A. In Receptor Methods for Source Apportionment: Real World Issues and Applications; Pace, T.G., Ed.; Air Pollution Control Assoc. Pittsburgh, PA, 1986, 78-93.

10. Harris, D.B. In Receptor Methods for Source Apportionment: Real World Issues and Applications; Pace, T.G., Ed.; Air Pollution Control Assoc. Pittsburgh, PA, 1986, 46-55.

11. Watson, J.G.; Robinson, N.F.; Chow, J.C., Henry, R.C., Kim, B.M,; Pace, T.G., Meyer, E.L.; Nguyen, Q. The US EPA/DRI Chemical Mass Balance Receptor Model, CMB 7.0 Environmental Software; 5(1), 1990.

12. Chow, J.C. In Receptor Methods for Source Apportionment: Real World Issues and Applications. Pace, T.G. Ed.; Air Pollution Control Assoc. Pittsburgh, PA, 1986, 194-211.

13. Stevens, R.K.; Pinto, J.P.; Willis, R.D.; Mamane, Y.; Novak, J.J.; Benes, I. In NATO ASI Series, Partnership Sub-Series 2, Environment. Allegrini, I. and De Santis, F. Eds.; 1996, Vol. 8, Urban Air Pollution.

14. Olmez, I.; Sheffield, A.E.; Gordon, G.E.; Houck, J.E.; Prichett, L.C.; Cooper, J.A.; Dzubay, T.G.; Bennett, R.L. JACPA. 1988, 38, 1392-1402.

15. Lee, S. Win, Pomalis, R., Young, B. and Dureau, R. In Proceedings from the International Symposium on Health Effects of Particulate Matter in Ambient Air. Air and Waste Management Association Special Publication, Prague, April 23-25, 1997, VIP-80, 546-556.

16. Lee, S. Win, Whaley, H., Pomalis, R. and Wong, J.K.L. ASME, EC, ISBN0-7918-1795-4, 1997, Vol.5: 97-105.

17. Lee, S. Win, Pomalis, R. and Kan, B. Fuel Processing Technology., 2000, 65-66 (0), 189202.

18. Lee, S. Win, Pomalis, R and Kan, B. Methodology development for measuring fine particulate emissions from fossil-fuel stationary combustion systems", Phase II, Report CETC 00-09 (CF), 2000.

19. Lee, S. Win. J. Air \& Waste Manage. Assoc., 2001, 51, 1568-1578.

20. Lee, S. Win, He, I., Herage, T. In Proceedings, $\mathrm{PM}_{2.5}$ and Electric Power Generation; Recent Findings and Implications. US Department of Energy. Philadelphia. April 9-10, 2002.

21. McCrillis, R.C. and Watts, R.R. J. Air \& Waste Manage. Assoc. 1992.

22. Miller, C.A., Ryan, J.V. and Lombardo, T. J. Air \& Waste Manag. Assoc., 1996, 46, 742-748.

23. Mohr, M., Schmatloch and Zaugg, H.P. In proceedings of the Second European Conference on Small Burner and Heating Technology, Stuttgart March 16-17, 2000.

24. Hildermann, L.M., Markowski, G.R., Jones, M.C. and Cass, G.R Aerosol Science and Technology, 1991, 14, 138-152.

25. Linak, W.P., Miller, C.A. and Wendt, J.O.L J. Air and Waste Manage. Assoc., 2000, 50, 15321544.

26. Rogge, W.F., Hildermann, L., Mazurek, M.A., Cass, G.L. and Simoneit, B.R. Environ. Sci. Technol., 1997, 31, 2731-2737. 
Paper No. 02-14

Oil Fired Pulse Combustion Boiler

\author{
Garry O. Hanson \\ HVAC Consultants, Inc. \\ 8453 Bridle Court \\ Florence, KY 41042 \\ Phone : 859 746-0826 \\ Fax: 859 746-0826 \\ E-Mail: gnhanson@aol.com
}




\begin{abstract}
Two models of oil fired pulse combustion commercial hot water boilers have been designed, developed and commercialized in a collaborative effort with a manufacturer. Prototype units were successfully tested in the laboratory with follow-up evaluation through the conduct of field trials and life cycle testing. In addition, both models were approved for compliance to the applicable Underwriters' Laboratories and Canadian Standards for oil burners and oil fired boilers. The units feature high reliability, excellent combustion characteristics, and significant energy savings generated from high efficiency and sealed combustion. Furthermore, the boilers are very compact with the ability to pass through a 36-inch wide doorway and utilize a unique heat exchanger and control system design.

This development represents the first product utilizing pulse combustion for fuel oil and by all standards is a significant technological breakthrough. This achievement opens the way to other developments which will place fuel oil fired appliances on a competitive leveling ground with gas fired appliances.
\end{abstract}

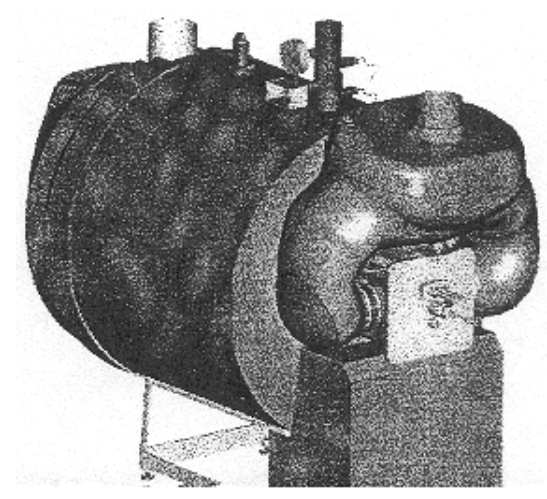

The first oil fired heating appliance to utilize pulse combustion technology. HISTORY OF PULSE COMBUSTION

The origin of pulse combustion can be traced to the German V-1 rocket which utilized an aerodynamic type valving system. The first commercial application of this technology to heating appliances on the North American continent occurred in Canada in the 1950 to 1960 time period. Greensteel Hydronics contracted with John Kitchen to apply the technology in his patents to manufacture and sell what was known then as the Lucas Rotax Pulsamatic residential hot water boiler. This boiler utilized mechanical type valves and fired on natural gas only. An estimated 540 units were installed in the Canadian area with ratings ranging from moderate to good success.

In 1979, Hydrotherm, Inc., introduced a new line of gas fired pulse combustion residential hot water boilers. These boilers were designed by John Kitchen but utilized a mechanical valve arrangement and combustion chamber-heat exchanger configuration quite different from the Lucas Rotax Pulsamatic boilers. 
In the 1960 to 1975 time period, considerable research was underway at the American Gas Association Research Laboratory to adapt gas fired pulse combustion technology to forced air furnaces. In 1976, an agreement between the Gas Research Institute, the American Gas Association Laboratories and Lennox Industries, Inc., led to the design and development of a number of models of gas fired pulse combustion forced air furnaces. Production was initiated in 1982 and in 1992 Lennox celebrated the completion of pulse furnace number one million to come off its Marshalltown, Iowa, assembly line.

In the 1980 to 1990 time period, Fulton Boiler Works, Inc., with funding and technical assistance from the Gas Research Institute, designed and developed a few models of gas fired pulse combustion commercial hot water boilers.

The only effort to develop an oil fired pulse combustion heating appliance was done by a Swiss company named Turbopuls. Also, in the 1980 to 1990 time period, they attempted to license a number of United States manufacturers in the manufacture and sale of a dual fuel gasoil pulse combustion residential hot water boiler. This boiler utilized a valving and combustion chamber design quite different from other gas pulse combustion counterparts and was never commercialized due to unacceptable performance characteristics.

\section{PROOF OF CONCEPT}

\section{DESIGN}

Prior technology that was applied in the design and development of this oil fired pulse combustion hot water boiler is revealed in the author's U.S. Patent Number 4,995,376, PULSE FURNACE, issued February 26, 1991. Figure 1 shows a cross section of the mixer head and combustion chamber arrangement.

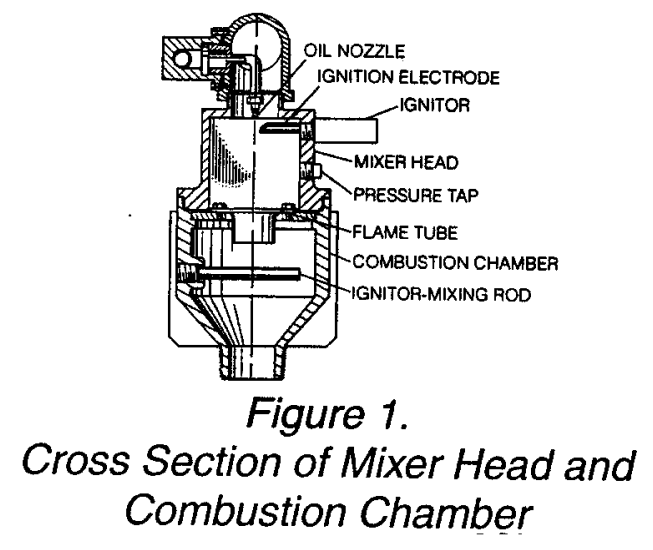

It can also be noted that the descriptive aspects of this patent are oriented toward a demonstrated successful mode with a residential forced air furnace (See Figure 2). 


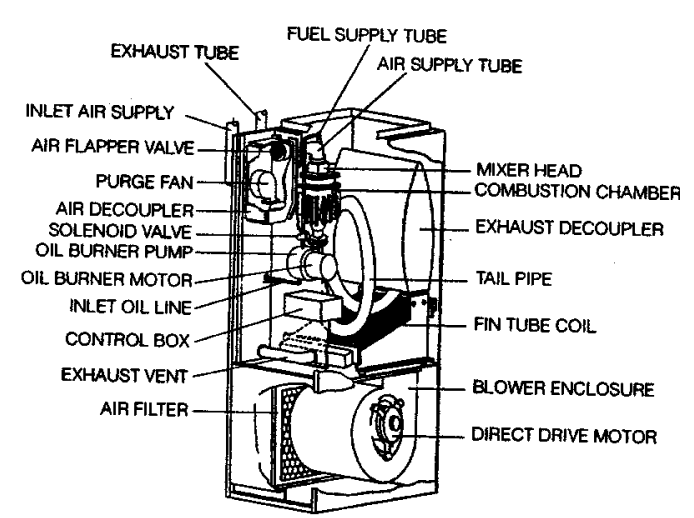

\section{Figure 2. \\ Possible Completed Assembly of an Oil Pulse Furnace}

At the suggestion of the author and acceptance by the manufacturer, it was decided to design to a 2,000,000 BTUh heating input rate. (Oil flow rate of 14.3 gallons per hour at 140,000 BTU's per gallon). Furthermore, because of the obvious risk involved, it was also agreed to build the prototype at minimum invested tooling cost.

Initial design was done with sketches utilizing iron pipe, plates, labor intensive construction and commercially available tailpipes that could be formed with standard mandrels. Special features applied to the design which are not revealed in the prior mentioned patent were utilization of two combustion air valves in parallel and a coaxial tube arrangement for the oil nozzle assembly. The coaxial tube arrangement permitted error free locating of the oil nozzle and also acted as a means for directing air flow over the nozzle (See Figure 3). These are important factors for successful operation of any oil fired appliance.

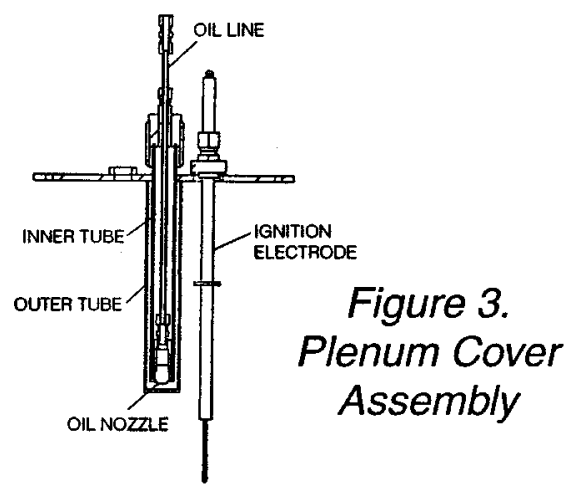

Formalized drawings were completed on a two dimensional CAD system, operational parts were specified and suppliers identified. Provisions were made in the design to locate thermocouples at appropriate locations to enable the evaluation of heat transfer characteristics and component temperatures. Provisions were also made for proper pressure taps to monitor operating pressures and resonant frequencies. 


\section{FABRICATION}

A custom job shop did most of the fabrication and all of the assembly of the verification model (See Figures 4 and 5).

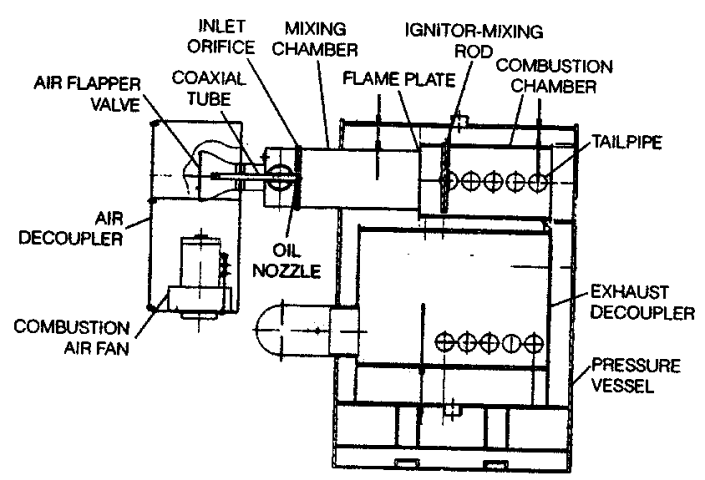

Figure 4.

Proof of Concept Model

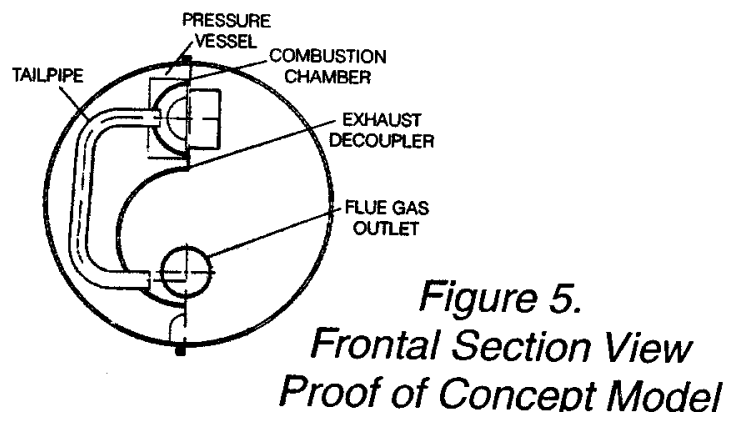

\section{TESTING}

Resonance was obtained on the first firing. However, operating pressures were somewhat lower than predicted. This produced the result of the two flapper valves being undersized and unable to provide sufficient excess combustion air for acceptable combustion performance. It was decided to reduce the heating input rate to match the sizing of the two combustion air flapper valves. Subsequently, the heating input rate was reduced to 1,200,000 BTUh (Oil flow rate of 8.6 gallons per hour at 140,000 BTU's per gallon) and complete operational characteristics were recorded at this input level. Due to the welding intensive construction, combustion performance could not be optimized. However, it was acceptable for providing necessary data for a decision as to the feasibility of proceeding ahead.

\section{EVALUATION}

Test data strongly suggested that an oil fired pulse combustion hot water boiler could be successfully designed and developed with potential for providing superior performance characteristics. It was felt that the shortcomings in combustion characteristics could be eliminated by identified adjustments in the interior parts of the mixer head-combustion chamber. Particularly pleasing were the results related to resonance stability, ignition reproducibility and heat transfer coefficients greater than those obtained with conventional mechanical burners. 


\section{MARKETING OBJECTIVES}

\section{PRODUCTION PROTOTYPE}

The Marketing Department set down certain specifications which were necessary for successful sales penetration into an identified market. Key objectives related to the design and development of this series of boilers were the following:

(1) Direct vent sealed combustion utilizing the smallest diameter tubing necessary for acceptable performance. Equivalent lengths for combustion air inlet and flue gas exhaust to be such as to satisfy the maximum expected for most installations.

(2) Packaged system completely assembled with only electrical, plumbing and direct vent tubing installation necessary to start operation.

(3) Boiler of such size as to be able to pass through a standard 36 inch doorway without disassembly of any component.

(4) Minimum flue loss efficiency of $83 \%$.

(5) Development of two models at base input rates of 350,000 and 500,000 BTUh.

(6) High reliability, low maintenance, with utilization of standard components.

(7) Manufacturing cost objectives as to enable the ability to compete with an identified competitor which had the greatest share of market.

(8) Obtain Underwriters' Laboratories and Canadian Standards approvals as to satisfy installation codes and acceptance by inspection authorities.

(9) ASME certified under Pressure Vessel Code Section IV for a maximum working pressure of 60 psig and a maximum temperature of 250 degrees Fahrenheit.

\section{DESIGN}

With application of test data from the Proof of Concept Model and prior technological know how, the first phase of the design involved calculations, sketches and modeling on the Pro Engineer three dimensional CAD system. At the very start, a decision was made to design the boiler for horizontal firing.

The mixer head, combustion chamber and tailpipe assembly were designed to resonate in a selected frequency range of 65 to 75 cycles per second. Prior experience dictated that this frequency range produced the best results for ignition and running stability. In the sizing of these components, heat transfer coefficients also had to be considered to meet the minimum flue loss efficiency goal of $83 \%$.

Operating pressures were predicted and flapper valves were designed and sized to provide sufficient excess combustion air for quality combustion characteristics (See Figure 6). As with the Proof of Concept Model, it was decided to utilize two flapper valves in parallel.

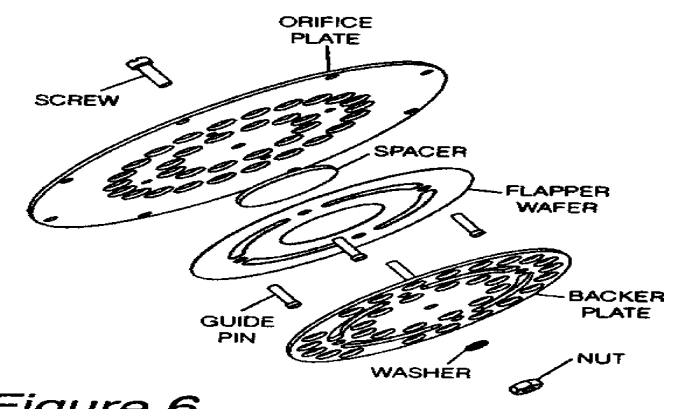

\section{Air Flapper Valve Assembly}


Mixer head and inlet plenum interior components, such as the flame plate and orifice assembly were also designed. In addition, the coaxial tube and oil nozzle assembly were defined.

The design of the tailpipe assembly had to be rather unique to satisfy compactness, resonant frequency and heat transfer requirements. This design employed unequal $U$ shaped tailpipes secured in a radial pattern on a flue gas entering lower tube sheet and a flue gas leaving upper tube sheet. (See Figure 7).

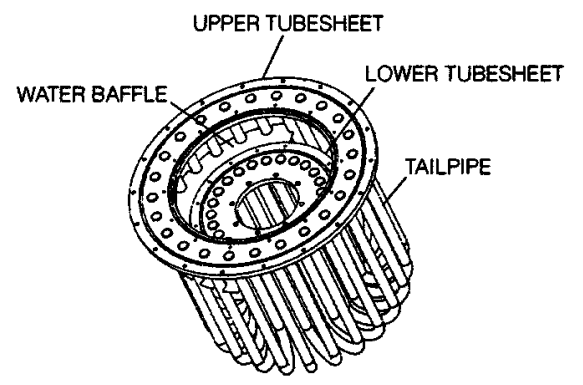

Figure 7.

Heat Exchanger Tube Bundle

In the design of the inlet plenum, mixing chamber and combustion chamber, it was decided to utilize a Class 35 gray iron casting because of the difficulty in fabricating the square mixing chamber to round combustion chamber transition. Furthermore, the casting eliminated possible joints that could leak. (See Figure 8).

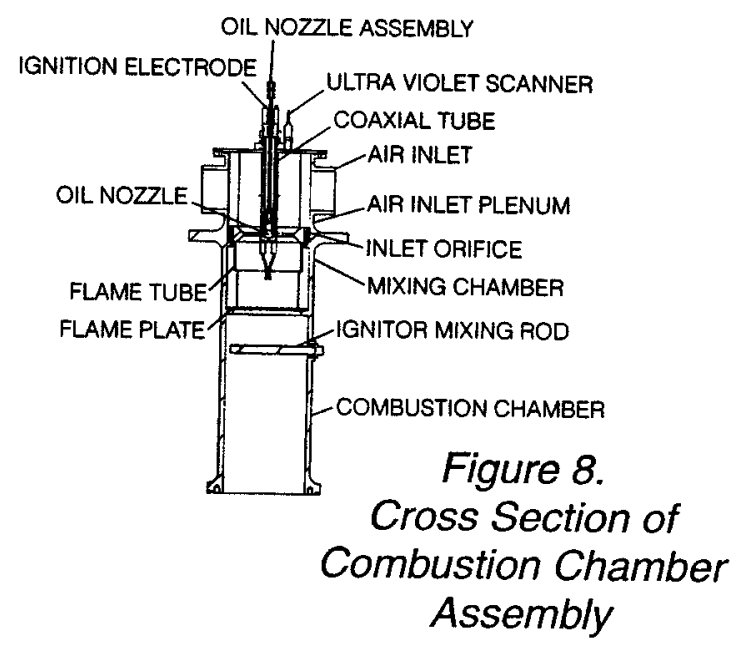

The design of the heat train was such as to permit disassembly of the pressure vessel to heat exchanger and individual heat exchanger parts for cleanability, as required in the Underwriters' Laboratories Standard Number 726, "Oil Fired Boiler Assemblies.” (See Figure 9). 


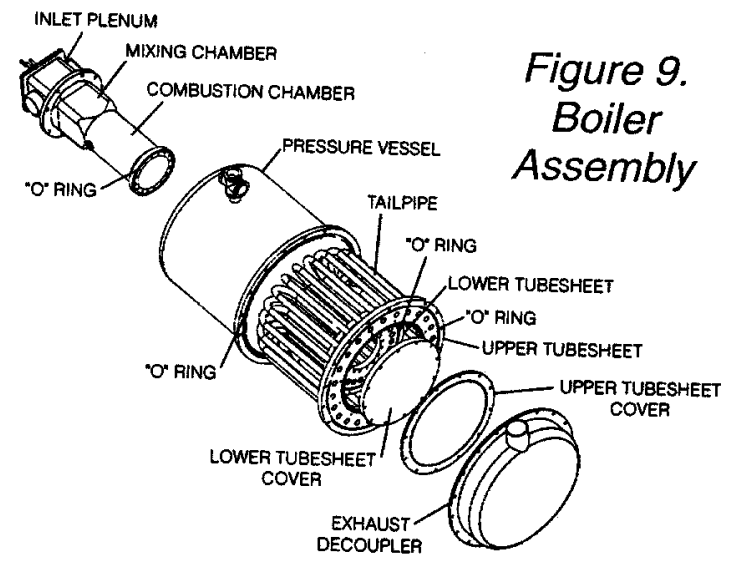

A positive function was designed into the control system which is not found in most other oil fired appliances. The logic requires that the spark ignition source must be proven before oil is admitted into the mixer head-combustion chamber. The control system functions are as follows:

(1) Upon a thermostat demand for heat, the combustion air fan is energized.

(2) Combustion air is proven by a pressure switch for a five second prepurge.

(3) The motor driving the oil pump and the ignition transformer are energized.

(4) For a timed trial of ten seconds, spark is proven by an ultraviolet scanner.

(5) A solenoid valve is energized allowing oil to flow from the pump through the oil nozzle and into the mixing chamber. Trial for ignition is ten seconds.

(6) Main flame is proven by the ultraviolet scanner.

(7) The ignition transformer is de-energized at the end of the ten second trial for ignition.

(8) After the heat demand has been satisfied, the solenoid valve and motor driving the oil pump are de-energized.

(9) The combustion air fan remains energized for a thirty second post purge.

\section{FABRICATION}

Fabrication of parts was done in the manufacturer's facility or by an outside source. Required functional purchased parts were received and all assembly completed at the manufacturer's facility.

\section{TESTING - LABORATORY}

The first test prototype was instrumented to provide operational data. Initial testing quickly indicated resonant frequency results at a level considerably lower than predicted and combustion quality less than acceptable. Resultant carbon monoxide and Bacharach smoke levels suggested a lack of homogenous air to fuel mix occurring in the mixing chamber. Design adjustments were made in the flame plate, inlet orifice assembly and coaxial tubes. Dramatically, the first firing with these changes produced greatly improved results with resonant frequencies falling within the predicted range and greatly reduced carbon monoxide and Bacharach smoke levels. Subsequent laboratory testing in the optimization of these component parts led to the attainment of a performance level which far exceeded anything that we had expected.

Combustion characteristics were outstanding, ignition was highly reproducible, resonance was stable, and efficiency and sealed combustion targets were exceeded. It was our opinion that we were now ready for field trial evaluation. 


\section{TESTING - FIELD TRIALS}

In the interests of timing and the ability to closely monitor performance characteristics, two field trial units were built and installed in the area of the manufacturer's facility in early March of 1999. One building served as the Administrative, Engineering, Marketing and Sales offices and the other was a manufacturing and office structure which produced a tank lining product. Both installations were quite similar with the exception of direct vent configuration. Both ducted the combustion air through the sidewall but in one flue gas exhaust was ducted through the roof, and, in the other, through the sidewall. Heating loads for both buildings at the peak of winter exceeded the 425,000 BTUh output of the field trial boilers. However, the late winter-early spring time of installation represented a heating load close match for both buildings. Consequently, considerable running time was experienced.

A great deal was learned about the operational aspects of this new technology. Combustion characteristics were relatively unchanged from time of start to time of discontinuance in early June. The results indicated superior clean, soot free combustion. This was verified visually by inspection of the heat exchanger passages, flue gas exhaust tubing and termination pieces. Component parts performed well without failure.

\section{TESTING - LIFE CYCLE}

Two boilers were set up for operation at burner on - burner off cycle rates simulating thermostat response to light and moderately heavy loads. The objectives were as follows:

(1) Possibly surface areas of the design which would require attention.

(2) Further verify long term reliability of ignition reproducibility, clean combustion characteristics, component parts and boiler construction.

Table 1 provides the results of each performance criteria as monitored at various points of accumulative cycles from start-up to the completion of 5403 cycles.

TABLE 1.

CYCLE TEST PERFORMANCE RESULTS

Conditions: Cycle rate of 6 minutes burner "on," 6 minutes burner "off"

\begin{tabular}{|c|c|c|c|c|c|c|c|c|}
\hline $\begin{array}{l}\text { NO. OF } \\
\text { CYCLES }\end{array}$ & $\begin{array}{l}\text { SPARK } \\
\text { SIGNAL }\end{array}$ & $\begin{array}{l}\text { FLAME } \\
\text { SIGNAL }\end{array}$ & $\begin{array}{c}\text { \% EXCESS } \\
\text { AIR }\end{array}$ & $\% \mathrm{CO} 2$ & $\begin{array}{c}\text { CO, PPM } \\
\text { (AIR FREE) }\end{array}$ & $\begin{array}{l}\text { NOx, PPM, } \\
(3 \% \text { O2) }\end{array}$ & $\begin{array}{l}\text { BACHARACH } \\
\text { SMOKE NO. }\end{array}$ & $\begin{array}{c}\text { \% FLUE LOSS } \\
\text { EFFICIENCY }\end{array}$ \\
\hline Start-up & Maximum & Maximum & 45 & 10.6 & 20 & 79 & 0 & 86.9 \\
\hline 569 & Maximum & Maximum & 43 & 10.7 & 14 & 69 & 0 & 87.3 \\
\hline 809 & Maximum & Maximum & 45 & 10.6 & 15 & 70 & 0 & 86.6 \\
\hline 1456 & Maximum & Maximum & 46 & 10.5 & 9 & 73 & 0 & 87.6 \\
\hline 2170 & Maximum & Maximum & 47 & 10.5 & 23 & 76 & 0 & 85.4 \\
\hline 3118 & Maximum & Maximum & 45 & 10.6 & 15 & 70 & 0 & 86.5 \\
\hline 3714 & Maximum & Maximum & 44 & 10.6 & 17 & 74 & 0 & 87.2 \\
\hline 4192 & Maximum & Maximum & 45 & 10.6 & 45 & 75 & 0 & 86.0 \\
\hline
\end{tabular}




$\begin{array}{llllllll}4791 & \text { Maximum Maximum } & 50 & 10.2 & 27 & 69 & 0 & 85.8 \\ 4912 & \text { Maximum Maximum } & 52 & 10.1 & 32 & 72 & 0 & 85.8 \\ 5030 & \text { Maximum Maximum } & 49 & 10.3 & 36 & 70 & 0 & 89.3 \\ 5403 & \text { Maximum Maximum } & 50 & 10.2 & 36 & 75 & 0 & 86.8 \\ \text { AVE. } & \text { Maximum Maximum } & \mathbf{4 7} & \mathbf{1 0 . 5} & \mathbf{2 4} & \mathbf{7 3} & \mathbf{0} & \mathbf{8 6 . 8} \\ \text { STD. } & \text { Maximum Maximum } & \mathbf{3} & \mathbf{0 . 2} & \mathbf{1 1} & \mathbf{3} & \mathbf{0} & \mathbf{1 . 0} \\ \text { DEV. } & & & & & & & \end{array}$

As can be observed, these results indicated a high degree of stability in spark signal, flame signal, combustion performance, and efficiency throughout the cycle test span.

\section{EVALUATION}

The overall evaluation of the field trial and life cycle efforts was that they were highly successful in proving that an oil fired pulse commercial hot water boiler was not only commercially viable, but had the potential for recognition as a superior product.

\section{MANUFACTURING - MARKETING MODEL}

\section{DESIGN AND FABRICATION}

A boiler was modified to comply with the notations made during the Underwriters' Laboratories Preliminary Investigation. It was the intent that this boiler would serve not only as the first manufacturing-marketing model for construction verification but also as the unit for standards approval testing.

\section{PATENTABILITY}

It was determined that the design had sufficient uniqueness of inventive novelty as to have patent possibilities. Consequently, an application for a United States patent was filed in mid September, 1999, and a patent was issued on December 19, 2000. The patent number is 6,161,506 and the title is "Pulsed Air Combustion High Capacity Boiler." The author is the sole inventor of this patent. Application for a Canadian patent was made at a later date and that patent is now pending.

\section{STANDARDS APPROVAL}

Application was made to Underwriters' Laboratories to test the boiler for compliance to the following UL and Canadian Standards:

(1) UL 726, Oil Fired Boiler Assemblies.

(2) UL 296, Oil Burners.

(3) CAN/CSA-B140.0-M87, General Requirements for Oil Burning Equipment.

(4) CAN/CSA-B140.7.2-1967, Oil Fired Steam and Hot Water Boilers.

(5) CAN/CSA-B140.2.1-M1990, Oil Burners, Atomizing Type. 
In early November of 1999, a test program verified that both models of the oil fired pulse combustion boiler successfully met all of the requirements of these standards.

\section{DISCUSSION}

Design and development of the oil fired pulse commercial hot water boiler could be described as a project of high risk interwoven with many technical challenges. The pioneering aspect was appealing because in many areas a precedent did not exist for the application of this technology.

Pulse combustion has a reputation for being sensitive, erratic, unpredictable, and, of course, due to the acoustic nature of the process, noisy. However, when the principles of resonance, correct design for quality air-fuel mix and identification of orifices in series were clearly understood, it was found that performance was highly predictable. This, of course, suggests what every designer of combustion devices strives for, control.

Clearly, in a professional sense, conquest of this technology was highly satisfying.

\section{CONCLUSIONS}

Development of the oil fired pulse combustion hot water boiler represents a significant technological breakthrough for the efficient combustion of fuel oil. This development will open the avenues for placing fuel oil heating appliances in a more competitive position with gas fired heating appliances. Another significant notation is that the application of this technology need not be limited only to boilers but could be applied to forced air furnaces, domestic water heaters and other appliances requiring fuel oil as the source.

All of the Marketing and personal objectives were met with special notations of high reliability, compactness, ability to apply direct vent sealed combustion, high efficiency and standards approvals to comply with the various codes in the market place.

\section{ACKNOWLEDGMENT}

The author wishes to thank the management of Patterson-Kelley, a HARSCO Company, for its forward vision in recognizing the tremendous potential of this product. Patterson-Kelley is the developer and manufacturer of the first oil fired pulse combustion heating appliance to be introduced into the market place. 
Paper No. 02-15

Evaluation and Testing for Commercialization

of Small Oil Fired Condensing Boilers in North America

Harvey G. Stenger, PE

53 Onondaga $\mathrm{St}$

Skaneateles, NY 13152

Phone: (315) 685-1800

Fax: (315) 685-1393

E-mail: hgstensr@yahoo.com 


\title{
EVALUATION AND TESTING FOR COMMERCIALIZATION OF SMALL OIL FIRED CONDENSING BOILERS IN NORTH AMERICA
}

\author{
Author: Harvey G. Stenger, PE
}

Small residential, oil fired water heaters and boilers designed for full flue gas condensing are rare. A few are being successfully marketed in Europe; until recently none in North America.

There is now at least one condensing oil fired residential size boiler/water heater available in North America and a few more will soon, or may have already, entered this market. This opens up new markets for oil water heater and boiler products.

This paper is a "snap shot" of the present status of a commercialization task in progress. We think the technical, scientific, and engineering professions generally use the phrase "Progress Report". We intend to publish additional technical reports as this commercialization task progresses.

In the past United States and Canadian [North American] hydronic heating applications experienced no change. The design space heating water temperatures were in the range of 160 to 200 degrees F. To provide these heating water temperatures required the combustion gas temperatures in the boiler heat exchanger area to be above the temperature where the water vapor created during the combustion process could condense into free water. Thus it was impossible to recover and effectively use the heat emitted during the flue gas water vapor condensation process. Most, if not all, North American manufactured hydronic water heater/boiler heat exchangers were, and still are made from low cost common grade cast iron, or steel that will reliably handle the higher flue gas temperatures, but will readily rust, and quickly fail once the flue gas is permitted to cool below a temperature where the water vapor in the flue gas starts condensing on to the boiler heat exchanger flue side surface. This creates a 5 to 10 per cent loss of heating efficiency when compared against heating boilers designed to reliably handle the condensed water vapor in the their heat exchanger. Fully condensing boilers, both gas and oil, will have AFUEs in the range of 87 to 97 per cent. Whereas the best noncondensing higher water temperature boilers will have AFUEs in the range of 81 to 85 per cent.

During the past six years the owner of every residential project I have been retained to engineer has requested hydronic radiant heat in all, or part of, their home. Happily I discovered home owners were already aware of the improved comfort and energy savings advantages of hydronic radiant floor and hydronic radiant panel heating before I was commissioned to do the mechanical, electrical, and plumbing engineering for the projects. They insisted on hydronic radiant floor heating. 
Why? Because the required heating water temperatures are lower. They are in the ideal range for radiant floor and radiant panels. The best temperature ranges for radiant floor or radiant panel heating and domestic water heating is 90 to 125 degree $\mathrm{F}$.

The actual surface temperature for a radiant floor in a comfort heating application should not be above 85 degrees $F$. For radiant wall and radiant ceiling panels used for comfort heating applications the water temperature is higher. I have never seen an application for radiant panels with a design temperature above 130 degrees $\mathrm{F}$. This was for a radiant ceiling in a commercial/industrial application. Surface temperatures for wall mounted radiant panels are kept low to prevent a burn hazard.

This increase in popularity of hydronic radiant floor and radiant panel heating in the new home construction market, has created a surging interest in condensing boilers; particularly the European style. They should be used just for applications where the normal control range upper limit is 80 degrees $\mathrm{C}$ and a manual reset safety control limit of 100 degrees $\mathrm{C}$ or less.

If the real advantages of the different hydrocarbon fuels, heating oil, natural gas, and propane, are discussed the homeowner will usually select heating oil over propane. Heating oil has the advantages of being safer, more reliable and there is open competition among the oil dealers. If natural gas is readily available in the neighborhood the consumer will probably choose it. However we have started to see changes in this attitude by the consumer even though the natural gas utilities offer many promotional and "up front financial incentives."

There are many condensing residential size oil fired boilers in commerce in Europe. I am aware of three beginning to emerge in the North America. They originated in:

\section{Germany}

\section{Switzerland}

\section{France}

\section{German model}

It fires down. From the standpoints of optimum efficiency, low maintenance costs, reliability, and competitive manufacturing costs "down firing" appears to be the optimum firing direction for fully condensing hydronic heating units. This is true no matter what type of hydrocarbon fuel is used. When firing down all the flue gas condensate can be drained directly into a large collection pan below the heat exchanger, and easily drained from the boiler/water heater. Firing down requires a novel boiler/burner design. It is expensive to manufacture when compared against existing horizontally fired oil boiler/water heaters. 
This German unit is floor mounted in the conventional manner. When I last checked only a few were installed and operating in North America. At this time commercialization activity of this boiler/water heater in North America seems to be inactive.

\section{Swiss model}

It is relatively new to the European market.

The Swiss unit is currently just beginning laboratory evaluation in a North American laboratory. None are operating in actual installations on our continent. There is, however, a small gas fired water heater/boiler with a similar heat exchanger just beginning commercialization in North America. I have evaluated the gas unit with this heat exchanger.

It is wall mounted.

\section{French model}

It has been successfully marketed in Europe for about ten years.

There are a few thousand in operation in Europe. Approximately one year ago it officially entered the North American residential home heating market. Between 50 and 100 of these units have been sold and installed in the United States and Canada. The last we checked they were all operating satisfactorily.

Both the European and the North American models are manufactured in the same factory in France. The only differences in the European and North American models are the electrical characteristics ( 120 volts 60 hertz instead of 220 volts 50 hertz) and the manufacturing location for the burner.

The burner used in the European boiler/water heater model has been designed and is manufactured in Sweden while the burner in the North American model is manufactured in the United States. Currently each burner is sent from the United States to France for installation and proof testing by the French boiler manufacturer. The fully tested unit (boiler and burner\} is returned to the United States for distribution and installation. The commercializing organization recognizes this to be a costly procedure, but necessary to assure product acceptance, quality, and product reliability.

Unlike most USA/ASME type oil fired boilers these French boilers are TRUE appliances. One of the goals the commercializing company has established is to minimize, or eliminate, all installer setup and trimming. At this time the commercializing company has reported many installers want to "experiment" or "unnecessarily trim-out" each of their installations. They have become accustomed to doing this "trim-out of noncondensing, ASME type residential oil fired boilers. This is not necessary for appliance 
type heating units specifically intended for medium to low temperature radiant heat applications.

\section{FLUE GAS CONDENSING \& PRODUCT RELIABILITY ASSURANCE}

To assure maximum heat recovery from the combustion process of the fuel-air mixture one of its by-products (water vapor) must be fully condensed in the boiler/water heater heat exchanger. This assures the effective recovery of two major energy losses inherent in all non-condensing boilers, water heaters and forced air furnaces.

These energy losses are:

a. Energy stored in the water vapor created during the combustion process.

b. Stand-by and off cycle losses.

Important boiler/water heater design requirements to assure reliable fully condensing oil fired unit with horizontal firing are:

a. Special metals in the boiler heat exchanger and in all other areas where there is a possibility for flue water vapor condensation. Because oil used for heating fuel always contains some sulfur the condensate will have sulfur in solution. Depending on the amount of dilution it can cause damaging corrosion. We know it will quickly cause failure of commonly used materials in non-condensing ASME boiler and residential forced air furnaces. After years of laboratory testing and field experience the French manufacturer has demonstrated that UNS-N-080904 stainless steel will withstand corrosion for at least 10 years of normal field use.

The French boiler has two heat exchangers. The Swiss boiler does not. It changes from corrosive to non-corrosive metals part way through a single heat exchanger. By observation we have determined the German boiler uses non-corrosive metal throughout a single heat exchanger.

In the French boiler the first (primary or non-condensing) heat exchanger is manufactured from typical carbon steel. To assure high reliability and long life flue gas water condensing must never occur in this heat exchanger. It will cause corrosion and early heat exchanger failures. The second (condensing) heat exchanger is fabricated from UNS-N-08904 stainless steel. It has $20.20 \% \mathrm{Cr}, 4.35 \% \mathrm{Mo}$, and $25 \% \mathrm{Ni}$. This is the alloy chosen in the chemical industry to carry and handle sulfuric acid.

The allowable sulfur content in the heating oil in France is $0.3 \%$. Independent laboratory tests have verified this alloy should last just as long if the sulfur content in the heating oil is $0.5 \%$ maximum. Also its use in the chemical industry to carry and handle sulfuric acid supports these laboratory tests. 
Changing the maximum sulfur level in the oil from .3\% to $.5 \%$ should have no more detrimental effect since the distillation occurring in the mixture water plus sulfuric acid leads to the same concentration of sulfuric acid on the condensing heat exchanger when the boiler is stopped.

In the French boiler the heating water mixing valve can be preset, or automatically controlled to assure no condensation will occur in the non-condensing heat exchanger.

This mixing valve also provides a very useful application feature. The French unit can simultaneously supply two different water temperatures. For example - low temperature radiant space heating and medium temperature water for heating domestic water in an indirect tank and/or the conventional higher temperature water for finned tube radiation, etc.

\section{SUMMARY}

While the North American residential oil based comfort heating market is comparatively small the energy converters (boilers, water heaters, and forced air furnaces) certainly represent a significant energy waste. Little, if any, fully condensing product research and development is on going in North America.

This market, residential fuel oil is primarily hydronics based and concentrated in the Northeastern USA and Eastern Canada.

Recently three European oil fired fully condensing boilers have appeared in the North American and Canadian residential markets. They are European units from France, Switzerland, and Germany.

All have application AFUEs over $90 \%$ medium temperature applications and over $95 \%$ when used for hydronic radiant floor or some panel applications.

So far my engineering and quality evaluation indicates the French units are the most proven from the standpoints of reliability and durability. A field verification program is ongoing to confirm the high reliability and customer acceptance experienced by this unit in Europe. 


\author{
Paper No. 02-16 \\ Description of a New Nozzle for Variable Firing Rates \\ Juergen Kohlmann, Prof. Dr.-Ing. habil. \\ University of Applied Sciences Berlin \\ Fachhochschule für Technik und Wirtschaft Berlin (FHTW) \\ Treskowallee 8 \\ Berlin, Berlin, D-10318, Germany \\ Phone: +44-30-47401-233 \\ Fax: +44-30-47401-306 \\ E-Mail: kohlmann@fhtw-berlin.de \\ Internet: www.fhtw-berlin.de
}




\section{Description of a new nozzle for variable firing rates}

\section{Introduction}

To regulate the firing rate of oil burners, the manufacturers are use two different techniques. One technique is the usage of spill-return or bypass nozzles. The other technology is the usage of standard simplex nozzles that can be switched on and switched off to represent different firing rates. The burner technology, to use the bypass nozzles is very complicated and needs additional equipment and components that are not necessary using standard burners. Using several simplex nozzles makes it necessary to have several nozzle adapters, solenoid valves and oil pumps. With the advent of environmental restrictions to reduce the exhaust emissions, it is a fact that the oil burner can only be used in one optimized point with a minimum of exhaust emissions. Bypass nozzles have the characteristics that the spray angle and spray pattern are varying when the user is varying the nozzle capacity and firing rate of the oil burner.

To eliminate the described disadvantages, a new nozzle system, based on the standard simplex nozzle technology has been developed. With the new nozzle system called "WSK" the firing rate can be varied very easy and the atomization of the liquid and the spray angle keeps constant.

\section{How the new nozzle system works}

In principle, there is no new component to build up the regulatable nozzle system. In figure 1 , a general description is presented. The oil flow, that is coming out from the exit of the oil pump is divided in two sub-flows.
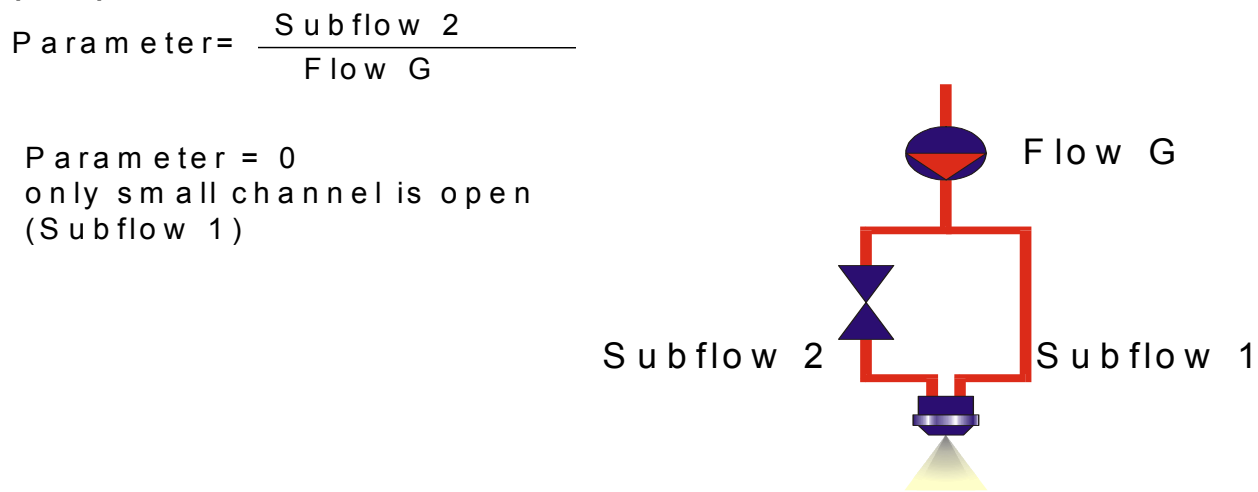

Figure 1: General description of the nozzle system and the nozzle adapter 
To feed the nozzle with the second oil flow, the second oil pipe is connected by a T-pipe with the outlet of the oil pump. "Sub-flow 1" and "Sub-flow 2" represent the complete oil flow "G". "Sub-flow 2" can be switched on and off by a simple shut off valve for step-less variation of the oil flow or can be regulated by a proportional valve for a continuos regulation of the oil flow. This occurs at a constant oil pressure.

With the valve closed, the burner will operate with the small firing rate. By continuously opening of the valve, the burner is able to increase the firing rate up to the maximum firing rate. In figure 2 the correlation between oil flow, the valve in the second oil pipe and oil pump is presented. The system is used in two different ways.

Keeping the oil pressure constant:

When the oil pressure is constant, e. g. 10 bar, and the valve to regulate "Sub-flow 2" is closed, than the nozzle capacity is $20 \%$ of the maximum design capacity. Opening the valve at the constant pressure of 10 bar increases the nozzle capacity up to $83 \%$ of the maximum design capacity. The flow rate is varied in a range of $1: 4$ at a constant pressure of 10 bar by opening and closing the valve. At constant oil pressure, the atomization and the spray angle remains constant at the different nozzle capacities. For different oil pressures with the valve closed, the lower line represents the nozzle capacities. With the valve open, the upper line is represents the nozzle capacities at different oil pressures.

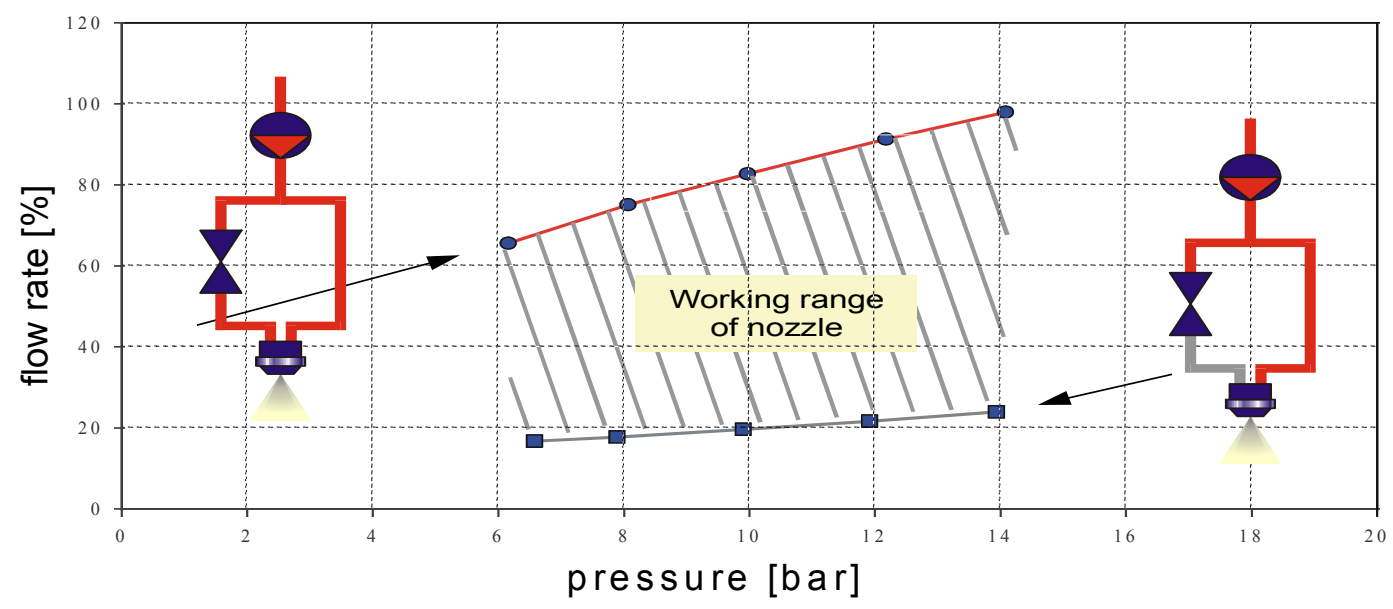

Figure 2: Working range of the nozzle 
Keeping the firing rate constant:

When the firing rate is constant, e. g. $65 \%$ of the maximum flow rate, this situation can be represented by a pressure of 6 bar and a completely opened valve or a pressure of 14 bar with a valve that is closed a little bit. Varying the pump pressure and the opening of the valve influences the spray angle as well as the atomization and the nozzle capacity can be kept constant. At a pressure of 6 bar the atomization process produces a lot of big droplets and a more narrow spray angle. At a pressure of 14 bar, the atomization becomes finer and the spray angle increases. This is commonly known from standard simplex nozzles.

The characteristics of the new nozzle system at constant oil pressure are:

- the system can be regulated for small firing rates in a range of $1: 3$,

- the spray angle and the spray pattern don't vary during modulation of the nozzle,

- the droplet size and the spectrum of the droplet sizes don't vary during modulation of the nozzle.

The wide range of the new nozzle system makes is possible to use the burner continuously; adjustable in a firing rate range that is actually needed by the heating system. Many the Start-Stop cycles can be eliminated. The range of regulation can become 1:8 for large power rates, e. g. $180 \mathrm{~kW}-1.500 \mathrm{~kW}$

\section{Presentation of some combustion results}

To test the new nozzle system a blue flame oil burner with a new and modern MEKU burner tube type "MB-8xx" was tested. The oil pressure varied between 6 bar and 12 bar because of the nozzle capacity. The air pressure represented by the air fan was 3-8 mbar. The maximum firing rate at the used MEKU burner tube was $18 \mathrm{~kW}$ at an air pressure of 8 mbar. Increasing the firing rate more than $18 \mathrm{~kW}$ by using a larger nozzle has the effect that $\lambda$ becomes less than one. For larger firing rates, bigger burner tubes are available. For the different oil pressures in the tests the different firing rates are presented in figure 3 .

At a firing rate less than $12-13 \mathrm{~kW}$ the air-pressure was very low and the mixing of oil droplets and air became bad. Figure 4 presents the air pressure in correlation to the power rate. The defect is based on the design of the special burner tube. The air-flow rate is restricted by a so called "air nozzle" in the burner tube and the construction needs a lot of speed to have a good mixture and combustion. 


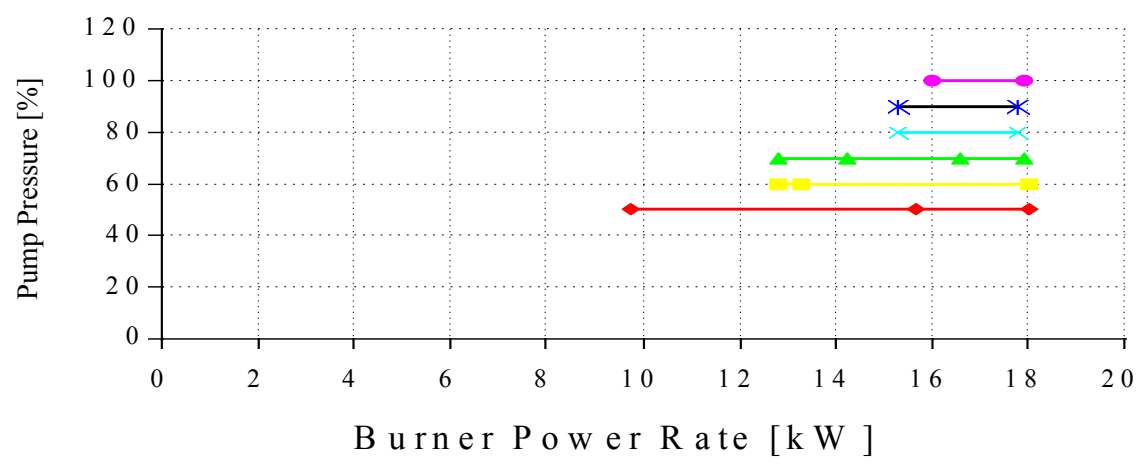

Figure 3: Correlation between firing rate and oil pressure

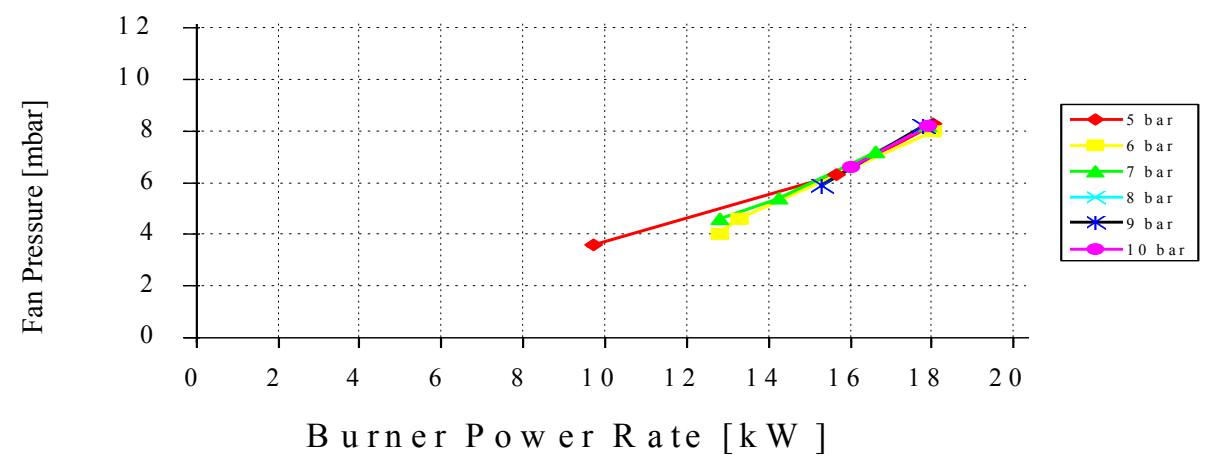

Figure 4: Air pressure vs. burner firing rate and pump pressure

With the new nozzle, the $\mathrm{NO}_{x}$-emissions kept constant on a low level between the minimum and maximum firing rate. In figure 5 the combustion results for the $\mathrm{NO}_{\mathrm{x}}$-emissions are presented. The CO-emissions are presented in figure 6 and were on a low level for burner firing rates not less than $12 \mathrm{~kW}$. For very low firing rates the $\mathrm{CO}$ emissions increases.

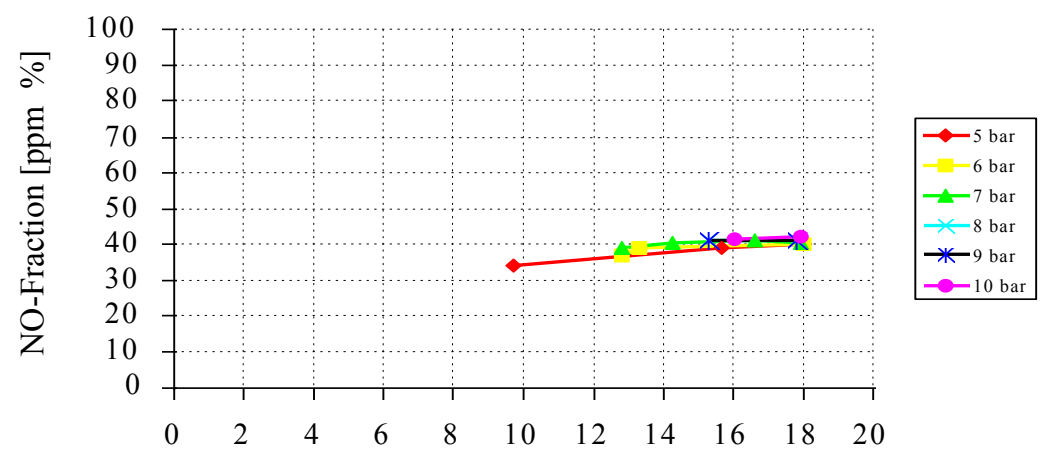

Burner Power Rate $[\mathrm{kW}]$

Figure 5: $\mathrm{NO}_{\mathrm{x}}$-emissions vs. burner firing rate and pump pressure 


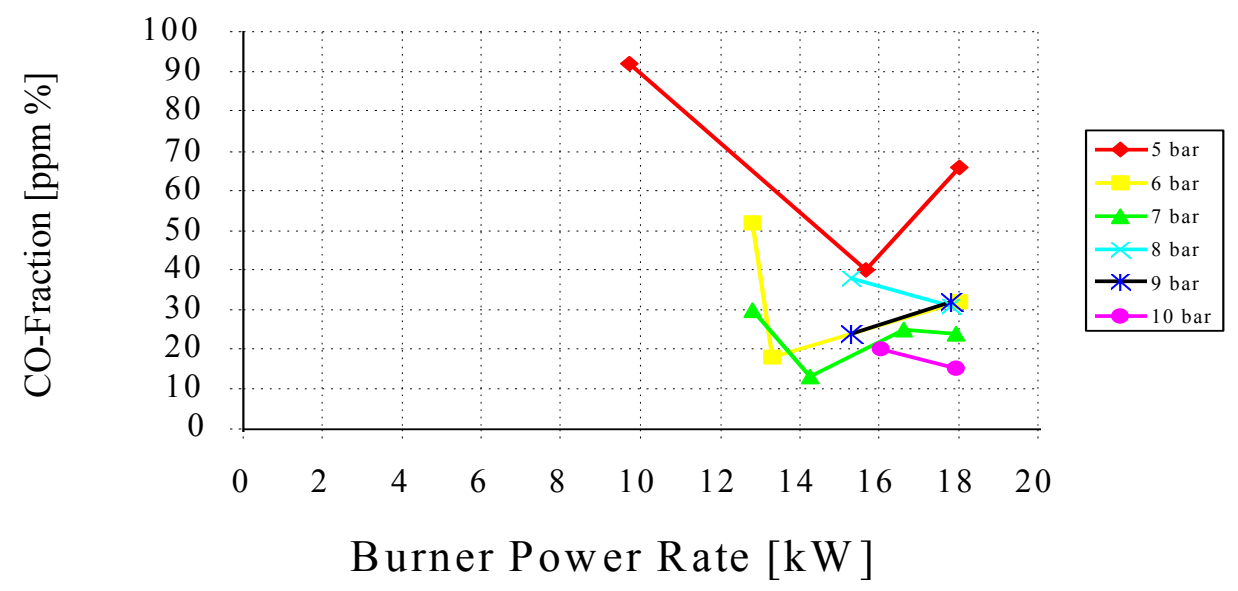

Figure 6: CO-emissions vs. burner firing rate and pump pressure

The smoke number during the test was held constant at a level of " 0 " in the complete range of tested firing rates.

\section{Conclusions and summary}

The results have shown that the new nozzle system has many advantages when compared to the standard systems that are currently used in the industry and marketplace.

- The oil burner is able to be used with different firing rates without using a bypass or spill-return system.

- The oil burner can be started at the minimum firing rate and than the firing rate can be increased by modulating in a step-less fashion up to the maximum firing rate. Also, the oil burner is able to be used with a firing rate that actually matches the heating load imposed on the system. The efficiency of the heating system is thus greatly increased.

- The constant atomization ensures that the combustion can be kept constant when the firing rate of the oil burner varies. The so-called "mixing-defects" of air and oil decreases and the exhaust emissions decreases as well

- Modulation of the oil burner is accomplished by using the proportional valve's control system to control a valve or plate in the combustion air intake system as well. The burner can then run with constant values for the combustion number $\lambda$.

- The construction of huge oil burner can be done in a more inexpensive way. A smaller pump can be used, some pressure sensors can be saved and the valves can be used in a smaller size. 
